LUCAS TUNIS MARTINS VELOZA

Determinação do prazo ótimo teórico em orçamentos de obras em função

da redução dos custos

São Paulo

2021 
Determinação do prazo ótimo teórico em orçamentos de obras em função da redução dos custos

Dissertação apresentada à Escola Politécnica da Universidade de São Paulo para obtenção do título de Mestre em Ciências

Orientador: Prof. Dr. Flávio Leal Maranhão 


\title{
Determinação do prazo ótimo teórico em orçamentos de obras em função da redução dos custos
}

\author{
Versão Corrigida
}

Dissertação apresentada à Escola Politécnica da Universidade de São Paulo para obtenção do título de Mestre em Ciências

Área de concentração: Inovação na Construção Civil

Orientador: Prof. Dr. Flávio Leal Maranhão

São Paulo 
Autorizo a reprodução e divulgação total ou parcial deste trabalho, por qualquer meio convencional ou eletrônico, para fins de estudo e pesquisa, desde que citada a fonte.

Este exemplar foi revisado e corrigido em relação à versão original, sob responsabilidade única do autor e com a anuência de seu orientador.

São Paulo, de de

Assinatura do autor:

Assinatura do orientador:

Catalogação-na-publicação

Veloza, Lucas Tunis M.

Determinação do prazo ótimo teórico em orçamentos de obras em função da redução dos custos / L. T. M. Veloza -- versão corr. -- São Paulo, 2021. $135 \mathrm{p}$.

Dissertação (Mestrado) - Escola Politécnica da Universidade de São Paulo. Departamento de Engenharia de Construção Civil.

1.tempo-custo trade-off 2.planejamento de obras 3.cronograma de projetos 4.gerenciamento de obras I.Universidade de São Paulo. Escola Politécnica. Departamento de Engenharia de Construção Civil II.t. 
Nome: VELOZA, Lucas Tunis Martins

Título: Determinação do prazo ótimo teórico em orçamentos de obras em função da redução dos custos

Dissertação apresentada à Escola Politécnica da Universidade de São Paulo para obtenção do título de Mestre em Ciências

Aprovado em:

\section{Banca Examinadora}

Prof. Dr.:

Instituição:

Julgamento:

Prof. Dr.:

Instituição:

Julgamento:

Prof. Dr.:

Instituição:

Julgamento: 
Dedico este trabalho a Sergio Tunis e Ivonir Veloza 


\section{AGRADECIMENTOS}

Agradeço inicialmente a Deus.

Agradeço ao meu pai, Sergio Tunis, por ser minha referência de vida e da profissão de Engenharia Civil.

Agradeço à minha mãe, Ivonir, por seus conselhos e por nunca me deixar desistir.

Agradeço ao meu irmão, Sergio Tunis, pelas valiosas dicas acadêmicas.

Agradeço à minha família em geral, tias, primos, avós, e aos meus amigos.

Agradeço aos meus companheiros de profissão, pelo conhecimento compartilhado que não se encontra em livros. Em especial, aos meus amigos Márcio Baptista e Mestre Luiz Gonzaga.

Agradeço ao professor Flávio Maranhão, pelas valiosas dicas, orientação e amizade. A sua mescla de experiência profissional e acadêmica foi fundamental para 0 desenvolvimento deste trabalho.

Por fim, agradeço ao Programa Construinova e à USP, pela oportunidade de fazer com que profissionais com experiência consigam migrar ao mundo acadêmico. Não tenho dúvidas de que ótimos frutos serão gerados. 


\section{RESUMO}

Ao longo dos anos, fica cada vez mais perceptível a valorização de técnicas de planejamento e gestão de obras visando melhorar a confiabilidade de cronogramas, prazos e estimativas de resultado dos projetos. Com a competitividade acentuada em que o mercado da construção se encontra, a precisão e a utilização desses recursos fazem-se fundamentais e necessárias para a sobrevivência e a diferenciação das empresas.

No desenvolvimento do orçamento e planejamento dos projetos, são calculados os custos diretos e indiretos que totalizam o projeto. Os custos diretos são aqueles que estão diretamente ligados aos serviços em si. Já os indiretos, não, são os custos necessários na empresa para o desenvolvimento e o apoio das atividades em geral.

O ponto-chave é que qualquer um desses custos é variável, dependente do fator tempo. Os custos indiretos possuem a característica de variar proporcionalmente ao tempo; e os diretos, de variar inversamente. Desta maneira, sabendo destas características específicas, pode-se chegar à conclusão de que, em um determinado tempo - tempo ou prazo ótimo, os custos totais do projeto podem totalizar o menor valor possível, e é em torno da estimativa deste tempo ótimo que o trabalho pretende ser desenvolvido. Elaborando um método para que empresas e orçamentistas possam ter um ponto de partida para o cálculo do tempo ótimo e ferramentas para analisar as características de variabilidade dos custos-prazos para cada um de seus projetos de construção.

A metodologia de pesquisa será balizada inicialmente no desenvolvimento de um método teórico que posteriormente será validado através da aplicação em dois projetos reais.

Palavras-chave: tempo-custo trade-off; planejamento de obras; cronograma de projetos; gerenciamento de obras. 


\begin{abstract}
Over the years, the valorization of construction planning and management techniques in order to improve the reliability of project schedules, deadlines and result estimates, is increasingly noticeable. The increased competitiveness that the construction market is facing makes that the precision and use of these resources be essential and necessary for the survival and differentiation of companies.

In the development of the budget and planning of the projects, the direct and indirect costs are calculated and make up the final value of the project. Direct costs are those that are directly linked to the services themselves, while indirect costs are the costs necessary in the company for the development and support of activities in general.

The key point is that any of these costs are time dependent variables, indirect costs have the characteristic of varying proportionally to time and direct costs of varying inversely. Thus, knowing these specific characteristics, it can be concluded that in a given time - optimal time or deadline, the total costs of the project can result the lowest possible value, and it is around the estimate of this optimum time that the work it intends to be developed. Thus developing a method so that companies and budgeters can have a starting point for calculating the optimum time and resources to analyze the characteristics of cost-term variability for each of their projects. The validation and explanation of the application of the method will be done through application in two real construction projects.
\end{abstract}

The research methodology will initially be guided by the development of a theoretical method that will later be validated through the application in two real projects.

Keywords: time-cost trade-off; construction planning; project scheduling; construction management. 


\section{LISTA DE FIGURAS}

Figura 1 - Etapas fundamentais do orçamento. Adaptado - Mattos (2006)............ 32

Figura 2 - Subcategorização de análises de trade-off. Adaptado - Hegazy (1999) 43

Figura 3 - Perfil da ponte a ser construída. Fonte: Autor .................................... 70

Figura 4 - Exemplo de metodologia de execução de estacas escavadas. .............. 70

Figura 5 - Exemplo de metodologia executiva de blocos. Fonte: Autor ................... 71

Figura 6 - Pilares executados em formas trepantes - Lances de concretagem.

Fonte: Autor...................................................................................... 72

Figura 7 - Travessas moldadas in loco - Vista superior do Pilar. Fonte: Autor ....... 73

Figura 8 - Seção típica das vigas pré-moldadas e protendidas. Fonte: Autor .......... 73

Figura 9 - Seção transversal de vigas pré-moldadas. Fonte: Autor ....................... 74

Figura 10 - Carrelones para o transporte de vigas pré-fabricadas. Fonte: Autor ..... 74

Figura 11 - Treliça lançadeira de vigas. Fonte: Autor ........................................ 75

Figura 12 - Tabuleiro da ponte, nas zonas de aproximação do vão central. Fonte:

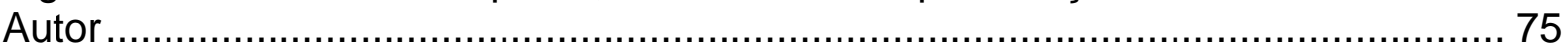

Figura 13 - Metodologia executiva dos balanços sucessivos. Fonte: Autor ............. 76

Figura 14 - Metodologia executiva dos balanços sucessivos. Fonte: Autor ............. 76

Figura 15 - Balanços sucessivos. Fonte: Autor................................................. 77

Figura 16 - Planilha de Cálculo dos custos variáveis.......................................... 91

Figura 17 - Cronograma Prazo Previsto $x$ Adotado = Prazo Ótimo ……........................ 95

Figura 18 - Planta do condomínio de casas (exemplo)....................................... 97

Figura 19 - Planilha de Cálculo dos Custos Variáveis ......................................... 109

Figura 20 - Cronograma Prazo Previsto x Adotado = Prazo Ótimo …....................... 114

Figura 21 - Cronograma Ponte 1,6 Km.................................................... 124

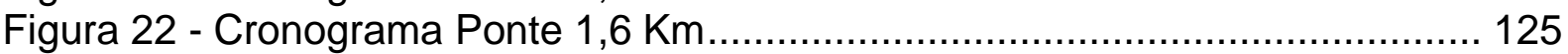

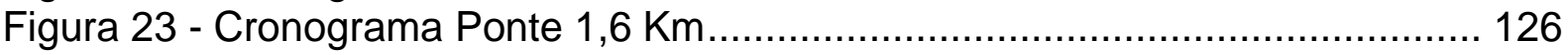

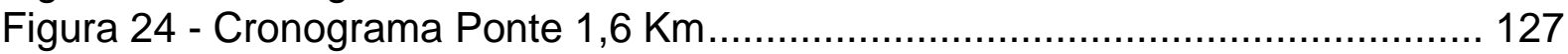

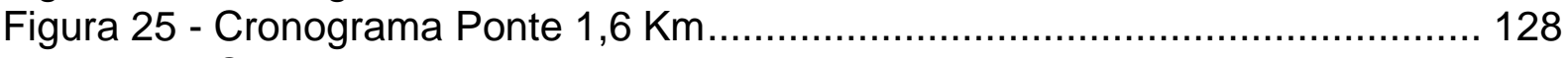

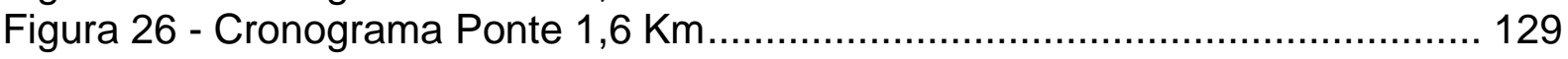

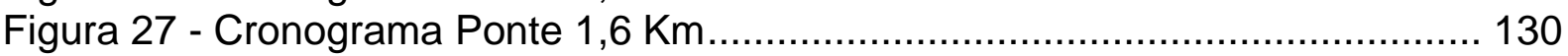

Figura 28 - Cronograma Ponte 1,6 Km..................................................... 131

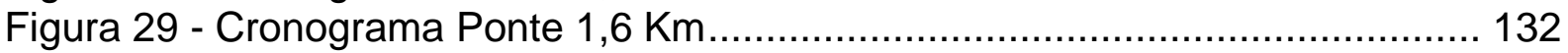

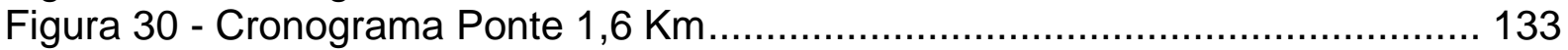

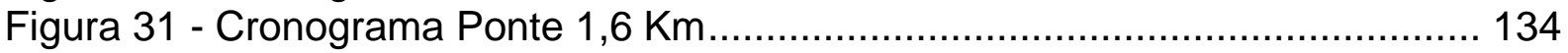

Figura 32 - Cronograma Ponte 1,6 Km.................................................... 135 


\section{LISTA DE QUADROS}

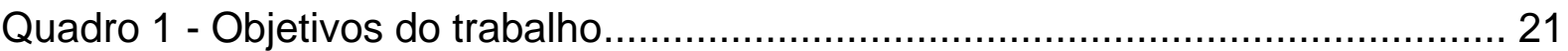

Quadro 2 - Metodologia do trabalho …........................................................ 22

Quadro 3 - Atividades intermediárias x resultados esperados.............................. 23

Quadro 4 - Exemplo de composição de serviço .................................................... 33

Quadro 5 - Composição de Serviço - Concreto $40 \mathrm{Mpa}$...................................... 34

Quadro 6 - Planilha de levantamento $x$ composições de custo .............................. 35

Quadro 7 - Valores dos custos x prazos utilizados no algoritmo. Adaptado - Feng

(1997) ............................................................................................... 42

Quadro 8 - Valores dos custos x prazos utilizados no algoritmo. Fonte: Chassiakos

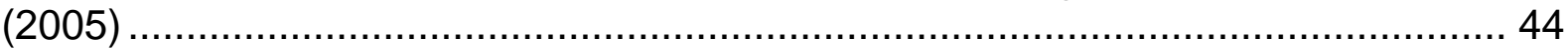

Quadro 9 - Variação dos custos x variação do prazo ........................................ 47

Quadro 10 - Variação dos custos $x$ variação do prazo ........................................ 48

Quadro 11 - Variabilidade HH x prazo .......................................................... 51

Quadro 12 - Indicadores da Equação de Prazo Ótimo ......................................... 53

Quadro 13 - Identificação dos Indicadores da Equação de Prazo Ótimo ................. 63

Quadro 14 - Identificação dos Indicadores da Equação de Prazo Ótimo - Item M't 77

Quadro 15 - Identificação dos Indicadores da Equação de Prazo Ótimo - Item M't 78

Quadro 16 - Quantitativo de resumo de serviços............................................... 78

Quadro 17 - Identificação dos Indicadores da Equação de Prazo Ótimo - Item Sm 79

Quadro 18 - Resumo dos principais materiais da Obra ....................................... 80

Quadro 19 - Identificação dos Indicadores da Equação de Prazo Ótimo - Item Mat'0

80

Quadro 20 - Identificação dos Indicadores da Equação de Prazo Ótimo - Itens Eq't e C

Quadro 21 - Identificação dos Indicadores da Equação de Prazo Ótimo - Itens Eq't e C.....

Quadro 22 - Identificação dos Indicadores da Equação de Prazo Ótimo - Item C't 82

Quadro 23 - Identificação dos custos do efetivo indireto mensal médio ................... 83

Quadro 24 - Identificação das despesas indiretas médias de canteiro e apoio ....... 83

Quadro 25 - Identificação dos Indicadores da Equação de Prazo Ótimo - Item A .. 84

Quadro 26 - Identificação do fator de rescisão $(A)$........................................... 85

Quadro 27 - Identificação dos Indicadores da Equação de Prazo Ótimo - Item B .. 85

Quadro 28 - Identificação dos Indicadores da Equação de Prazo Ótimo - Item D .. 86

Quadro 29 - Identificação do item D - custos variáveis de canteiro ........................ 86

Quadro 30 - Identificação dos Indicadores da Equação de Prazo Ótimo - Item E .. 86

Quadro 31 - Identificação dos custos médios de treinamento por funcionário......... 86

Quadro 32 - Identificação dos Indicadores da Equação de Prazo Ótimo - Item F .. 87

Quadro 33 - Identificação dos custos fixos e variáveis do Item $F$......................... 87

Quadro 34 - Identificação dos Indicadores da Equação de Prazo Ótimo - Item G.. 87

Quadro 35 - Identificação dos Indicadores da Equação de Prazo Ótimo - Item H.. 88

Quadro 36 - Identificação dos Indicadores da Equação de Prazo Ótimo - Item R.. 89

Quadro 37 - Identificação dos Indicadores da Equação de Prazo Ótimo - Item S.. 89

Quadro 38 - Identificação dos Indicadores da Equação de Prazo Ótimo - Item K .. 90

Quadro 39 - Identificação do fator de pico K...................................................... 90

Quadro 40 - Tabela de resumo de Indicadores da Equação de Prazo Ótimo .......... 90

Quadro 41 - Cálculo da economia gerada pelo método ........................................ 94

Quadro 42 - Cálculo da economia máxima gerada pelo método ............................. 94

Quadro 43 - Cálculo da zona de potencial de inovação ......................................... 96 
Quadro 44 - Identificação dos Indicadores da Equação de Prazo Ótimo - Item M’t 98 Quadro 45 - Identificação dos Indicadores da Equação de Prazo Ótimo - Item M’t 99 Quadro 46 - Quantitativo de resumo de serviços....

Quadro 47 - Identificação dos Indicadores da Equação de Prazo Ótimo - Item Sm

Quadro 48 - Quadro de resumo com principais materiais da Obra..................... 100

Quadro 49 - Identificação dos Indicadores da Equação de Prazo Ótimo - Item Mat'0 101

Quadro 50 - Identificação dos Indicadores da Equação de Prazo Ótimo - Itens Eq't e C 101

Quadro 51 - Identificação dos Indicadores da Equação de Prazo Ótimo - Item C’t 102

Quadro 52 - Identificação dos custos do efetivo indireto mensal médio ................ 102

Quadro 53 - Identificação das despesas indiretas médias de canteiro e apoio ..... 102

Quadro 54 - Identificação dos Indicadores da Equação de Prazo Ótimo - Item A 103

Quadro 55 - Identificação do fator de rescisão $(A)$........................................ 104

Quadro 56 - Identificação dos Indicadores da Equação de Prazo Ótimo - Item B 104

Quadro 57 - Identificação dos Indicadores da Equação de Prazo Ótimo - Item D 104

Quadro 58 - Identificação do Item D - custos variáveis de canteiro ...................... 105

Quadro 59 - Identificação dos Indicadores da Equação de Prazo Ótimo - Item E 105

Quadro 60 - Identificação dos custos médios de treinamento por funcionário....... 105

Quadro 61 - Identificação dos Indicadores da Equação de Prazo Ótimo - Item F 105

Quadro 62 - Identificação dos custos fixos e variáveis do Item $F$........................ 106

Quadro 63 - Identificação dos Indicadores da Equação de Prazo Ótimo - Item G 106

Quadro 64 - Identificação dos Indicadores da Equação de Prazo Ótimo - Item H 107

Quadro 65 - Identificação dos Indicadores da Equação de Prazo Ótimo - Item R 107

Quadro 66 - Identificação dos Indicadores da Equação de Prazo Ótimo - Item S 107

Quadro 67 - Identificação dos Indicadores da Equação de Prazo Ótimo - Item K 107

Quadro 68 - Identificação do fator de pico K............................................... 108

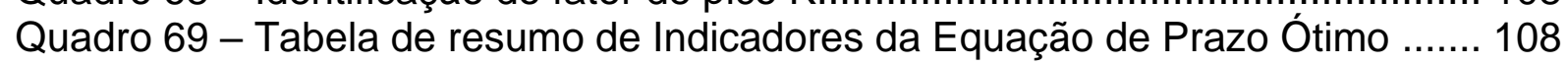

Quadro 70 - Cálculo da economia gerada pelo método ................................... 112

Quadro 71 - Composição de serviço - Aço CA-50 ......................................... 121

Quadro 72 - Composição de serviço - Lançamento de pré-lajes .......................... 121

Quadro 73 - Composição de serviço - Forma metálica ....................................... 122

Quadro 74 - Composição de serviço - Concreto 40 Mpa .................................... 123 


\section{LISTA DE GRÁFICOS}

Gráfico 1 - Curva de prazos x custos totais do projeto - Adaptado de Hirschfeld

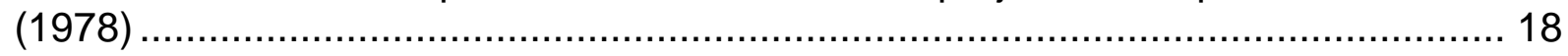

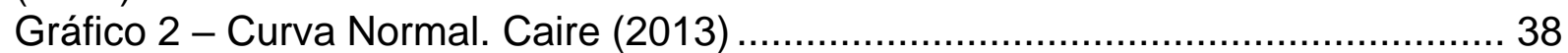

Gráfico 3 - Curva típica custos x prazo. Adaptado - Kelly (2009) …...................... 40

Gráfico 4 - Curva típica custos x prazo (Adaptado). Fonte: Feng (1997)................ 41

Gráfico 5 - Resultados custos x prazo utilizando algoritmos genéricos. Fonte: Feng

(1997)

41

Gráfico 6 - Relacionamento típico entre custos x prazos. Fonte: Hegazy (1999) .... 43

Gráfico 7 - Resultados do algoritmo. Fonte: Chassiakos (2005)........................... 45

Gráfico 8 - Curva de determinação de prazo ótimo (apenas custos variáveis)........ 55

Gráfico 9 - Curva de determinação de prazo ótimo (custos variáveis e invariáveis) 56

Gráfico 10 - Curva de determinação de prazo ótimo (apenas custos variáveis) ...... 57

Gráfico 11 - Curva de determinação de prazo ótimo (apenas custos variáveis) ...... 58

Gráfico 12 - Curva de determinação de prazo ótimo (apenas custos variáveis) -

Zonas dos projetos ........................................................................................ 60

Gráfico 13 - Curva de Perda de produtividade em função do prazo do projeto ....... 85

Gráfico 14 - Curva de perda em função do prazo do projeto .................................. 88

Gráfico 15 - Curva de aumento de horas extras em função do prazo ...................... 89

Gráfico 16 - Curva de prazo ótimo - Ponte 1,6 Km ........................................... 92

Gráfico 17 - Curva de prazo ótimo - Ponte 1,6 Km (zonas de projeto) ................... 93

Gráfico 18 - Gráfico índice G - Condomínio de casas......................................... 106

Gráfico 19 - Curva de prazo ótimo - Condomínio de casas ................................. 110

Gráfico 20 - Curva de prazo ótimo - Condomínio de casas (zonas de projeto)..... 111 


\section{SUMÁRIO}

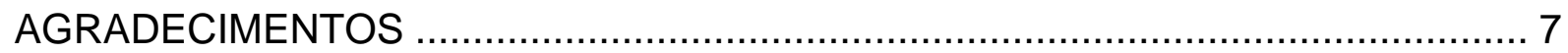

RESUMO

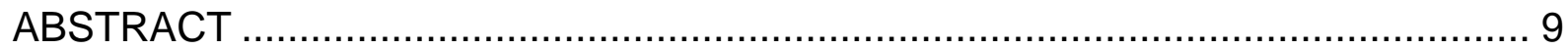

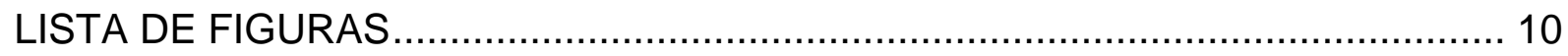

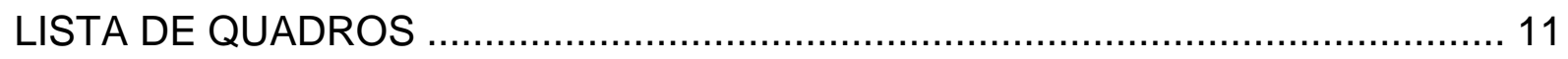

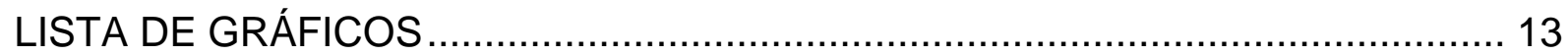

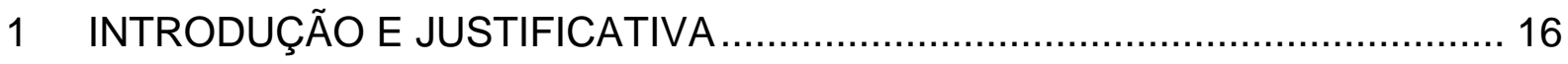

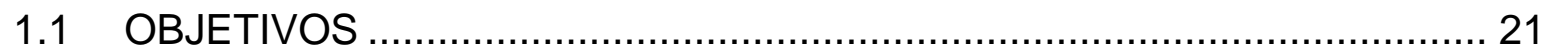

1.2 METODOLOGIA PARA O DESENVOLVIMENTO DO TRABALHO ............ 22

1.3 ESTRUTURA E ETAPAS DE DESENVOLVIMENTO DO TRABALHO ....... 23

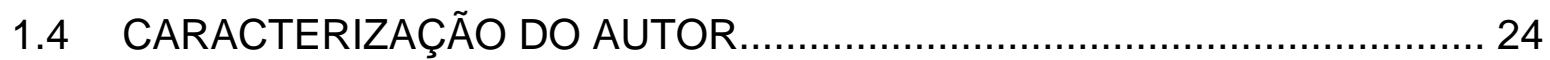

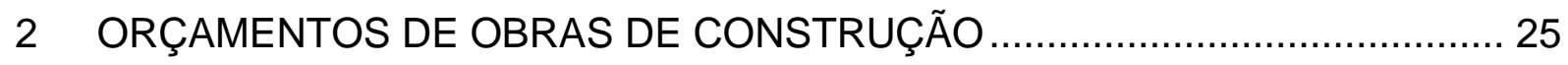

2.1 CONCEPÇÃO DO ORÇAMENTO DE OBRAS …....................................... 25

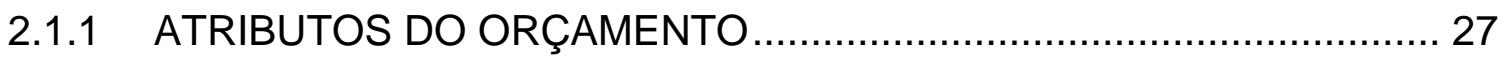

2.1.2 ETAPAS DA ORÇAMENTAÇÃO ................................................... 30

2.1.3 ABORDAGEM MATEMÁTICA DA ORÇAMENTAÇÃO........................ 32

2.2 PARTICULARIDADES DOS CRONOGRAMAS DAS OBRAS: CURVA S .. 38

2.3 RELAÇÃO TEMPO-CUSTO EM PROJETOS …......................................... 39

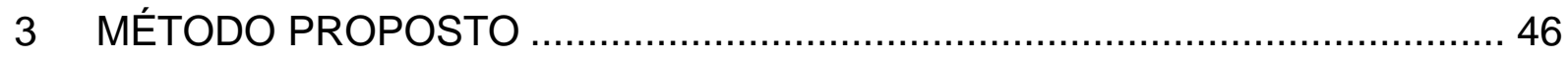

3.1 MÉTODO PROPOSTO - ABORDAGEM MATEMÁTICA ........................... 46

3.1.1 ABORDAGEM MATEMÁTICA - GENERALIZAÇÕES ….................... 56

3.1.2 ABORDAGEM FINANCEIRA - RECEITAS E REMUNERAÇÃO.......... 60

3.1.3 DESEMBOLSO FINANCEIRO .................................................... 61

3.1.4 PROCEDIMENTOS E ETAPAS DE APLICAÇÃO DA METODOLOGIA62

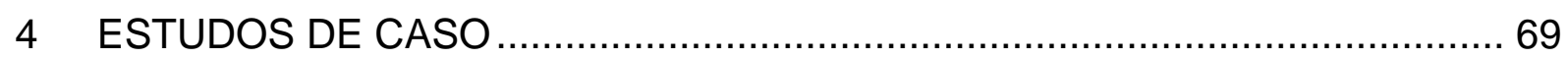

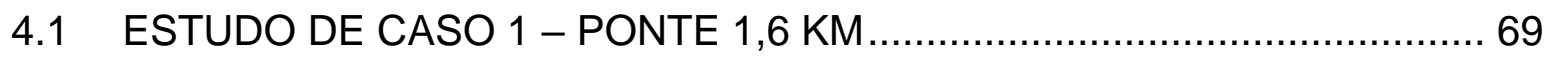

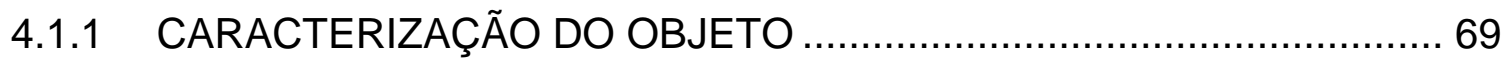

4.1.2 PARÂMETROS DE REFERÊNCIA DAS VARIÁVEIS DA EQUAÇÃO.. 77

4.1.3 DETERMINAÇÃO DO PRAZO ÓTIMO TEÓRICO ….......................... 91

4.1.4 ESTUDO DA CURVA DE CUSTOS VARIÁVEIS ................................. 92

4.1.5 VERIFICAÇÃO SE O PRAZO ESTIMADO INICIALMENTE É MAIOR OU MENOR QUE O PRAZO ÓTIMO DETERMINADO ........................................ 92

4.1.6 RECÁLCULO E DETERMINAÇ̃̃O DO CRONOGRAMA A PONTOLIMITE DE ACORDO COM A DEFINIÇẨO ADOTADA NA ETAPA ANTERIOR93 4.1.7 CÁLCULO FINAL DO POTENCIAL DE ECONOMIA UTILIZANDO PARÂMETROS DO CRONOGRAMA RECALCULADO 
4.2 ESTUDO DE CASO 2 - CONDOMÍNIO DE 45 CASAS ….......................... 96

4.2.1 CARACTERIZAÇÃO DO OBJETO ….............................................. 96

4.2.2 PARÂMETROS DE REFERÊNCIA DAS VARIÁVEIS DA EQUAÇÃO.. 98

4.2.3 DETERMINAÇÃO DO PRAZO ÓTIMO TEÓRICO ............................ 108

4.2.4 ESTUDO DA CURVA DE CUSTOS VARIÁVEIS .............................. 109

4.2.5 VERIFICAÇÃO SE O PRAZO ESTIMADO INICIALMENTE É MAIOR OU MENOR QUE O PRAZO ÓTIMO DETERMINADO ……................................ 110

4.2.6 RECÁLCULO E DETERMINAÇÃO DO CRONOGRAMA A PONTOLIMITE DE ACORDO COM A DEFINIÇÃO ADOTADA NA ETAPA ANTERIOR 110

4.2.7 CÁLCULO FINAL DO POTENCIAL DE ECONOMIA UTILIZANDO PARÂMETROS DO CRONOGRAMA RECALCULADO .................................. 111

5 CONCLUSÃO E FUTUROS DESENVOLVIMENTOS …............................... 116

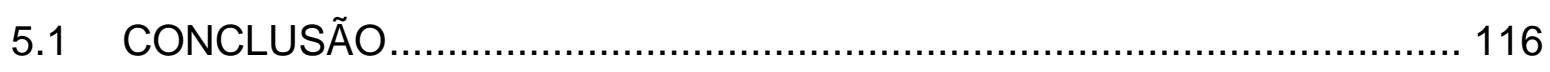

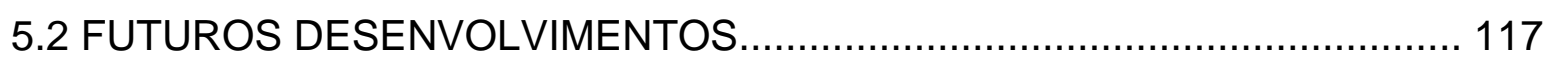

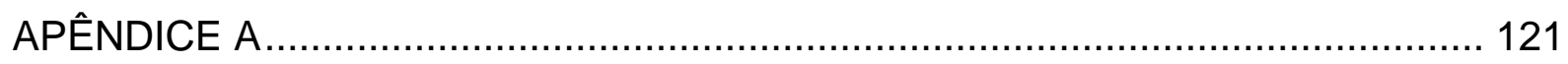

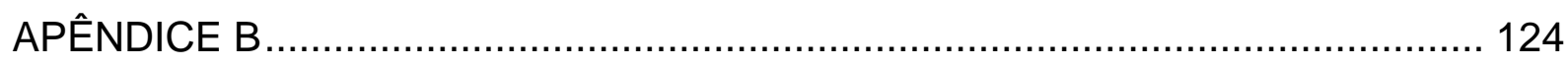




\section{INTRODUÇÃO E JUSTIFICATIVA}

O termo projeto tem sido associado no Brasil ao design das diferentes disciplinas (civil, hidráulica, arquitetura, entre outras) e ao empreendimento englobando todas as fases e planos necessários para o seu desenvolvimento. Nesta última, temos uma conceituação muito mais abrangente que engloba todos os esforços temporais incorridos para se gerar um produto específico.

Segundo o Project Management Institute - (PMI, 2008), projetos são conjuntos de esforços temporários para criar um produto, serviço ou resultado exclusivo. Eles são normalmente autorizados como resultado de uma ou mais considerações estratégicas, como, por exemplo, demanda de mercado, necessidade organizacional, solicitação de um cliente, avanço tecnológico ou até mesmo um requisito legal.

Meredith, Mantel e Shafer (2015) apontam para o fato de os projetos serem complexos o suficiente e necessitarem de uma capacidade de coordenação específica e de um controle detalhado dos recursos disponibilizados.

A Construção Civil é um setor que se caracteriza por possuir uma parcela majoritária de atividades baseada em projetos (empreendimentos), ou seja, a maior parte dos seus recursos é destinada aos esforços temporários para criar um produto, serviço ou resultado exclusivo.

Infelizmente trata-se de um setor com problemas de credibilidade, escassez de oportunidades, baixo investimento em novas tecnologias e competividade extremamente elevada.

Por isso o menor custo final de um projeto tem se tornado, muitas vezes, o principal elemento de diferenciação na competitividade entre as empresas durante as etapas de concorrência. Seguindo esta tendência, as empresas têm feito uma busca constante por melhorias em suas etapas orçamentárias a fim de se obter redução de custos através da melhoria de ferramentas de gestão. Em muitos casos, elas acabam se deparando com uma situação na qual essa redução de custo só é possível ou razoável com uma redução do prazo do projeto.

Balizado na experiência profissional do autor, que pôde observar esta busca constante das empresas de construção na redução dos custos dos empreendimentos através de iterações em seus prazos, veio a decisão do desenvolvimento deste trabalho, o qual busca estabelecer um método prático que possibilite aos orçamentistas obterem um ponto de partida mais preciso para a busca do prazo ótimo do empreendimento, ou seja, o prazo em que o empreendimento tem o menor custo.

Dito isto, seguem resumidas as principais justificativas para o desenvolvimento deste trabalho:

- Altíssima probabilidade de geração de economia de valor, desenvolvimento e melhoria de competitividade para as empresas. 
- Grandes erros em estimativas de custos e prazos de obras, que geram atrasos, prejuízos e aditivos - fatores que são um dos graves problemas que enfrentamos nos setores público e privado e que incentivam a corrupção.

- Falta de confiabilidade nas margens de lucro contratuais e nas projeções de investimento durante a orçamentação e o planejamento dos projetos, dificultando o relacionamento com investidores e a captação de recursos.

- Gastos excessivos com mão de obra, materiais, equipamentos e custos indiretos.

- Má imagem do setor perante a população, visto que existem inúmeras obras paralisadas e que não terminam devido aos problemas levantados acima.

- Atraso em comparação com outras indústrias que, de maneira geral, conseguem abordar tais problemas com maior confiabilidade e de maneira mais científica e técnica.

A Câmara Brasileira da Indústria da Construção - CBIC (2011) aponta que a necessidade de se construir em prazos mais curtos para viabilizar os custos tem impulsionado as mudanças das tecnologias construtivas, levando empresas ao desenvolvimento de inovações ou à incorporação de inovações em seus processos.

Os projetos de Construção Civil apresentam significativas variações quando se consideram os aspectos relacionados aos custos e prazos. Observando o fator de temporalidade dos projetos, aparece o questionamento se é viável, de alguma maneira, desenvolver e aplicar métodos, durante a etapa orçamentária, que possibilitem correlacionar o custo e o prazo de um projeto, de tal modo que se estime um prazo que possibilite a redução do custo total, ou seja, encontrar um prazo ótimo teórico.

Durante a orçamentação dos projetos de construção, as empresas calculam todos os custos diretos e indiretos que compõem o projeto para um prazo pré-determinado pelo cliente ou pelas estimativas de seus orçamentistas e planejadores. Não é usual as empresas fazerem iterações de prazo durante a etapa de orçamentação, pois se acredita que há restrições nos fluxos de caixa do cliente principalmente devido à complexidade dessa atividade. Mesmo quando há tal procedimento, ele não é feito por um método estruturado.

Tradicionalmente os custos diretos são aqueles que estão diretamente ligados às quantidades e aos serviços em si. Já os indiretos são necessários para o desenvolvimento das atividades, ocorrendo independentemente de haver produção direta, por isso são tidos como dependentes do tempo ou da permanência.

Os custos indiretos variam proporcionalmente ao prazo do projeto, e os diretos tendem a variar inversamente, Hirschfeld (1978). Os indiretos variam proporcionalmente justamente pela sua característica de permanência ou de dependência do tempo. Já os diretos tendem a ter uma variação inversamente proporcional ao prazo justamente pelas questões de aumento de necessidade de recursos, culminando em aumento de custos de mobilizações de equipamentos, custos de rescisões trabalhistas, encargos, aumento de rotatividade, entre outros fatores. Uma abordagem detalhada sobre estas características é abordada no item 3.1 e em seus subitens. 
A abordagem da determinação de um custo ótimo em função do prazo não é nova. Hirschfeld (1978) cita em seu trabalho a determinação do custo total ótimo através da representação gráfica da curva de custos totais em um projeto, conforme o Gráfico 1, levando em conta as características de variabilidade dos custos diretos e indiretos em função do tempo. Gadelha (2011) faz exatamente a mesma abordagem gráfica em seu livro de orçamentos na construção pesada.

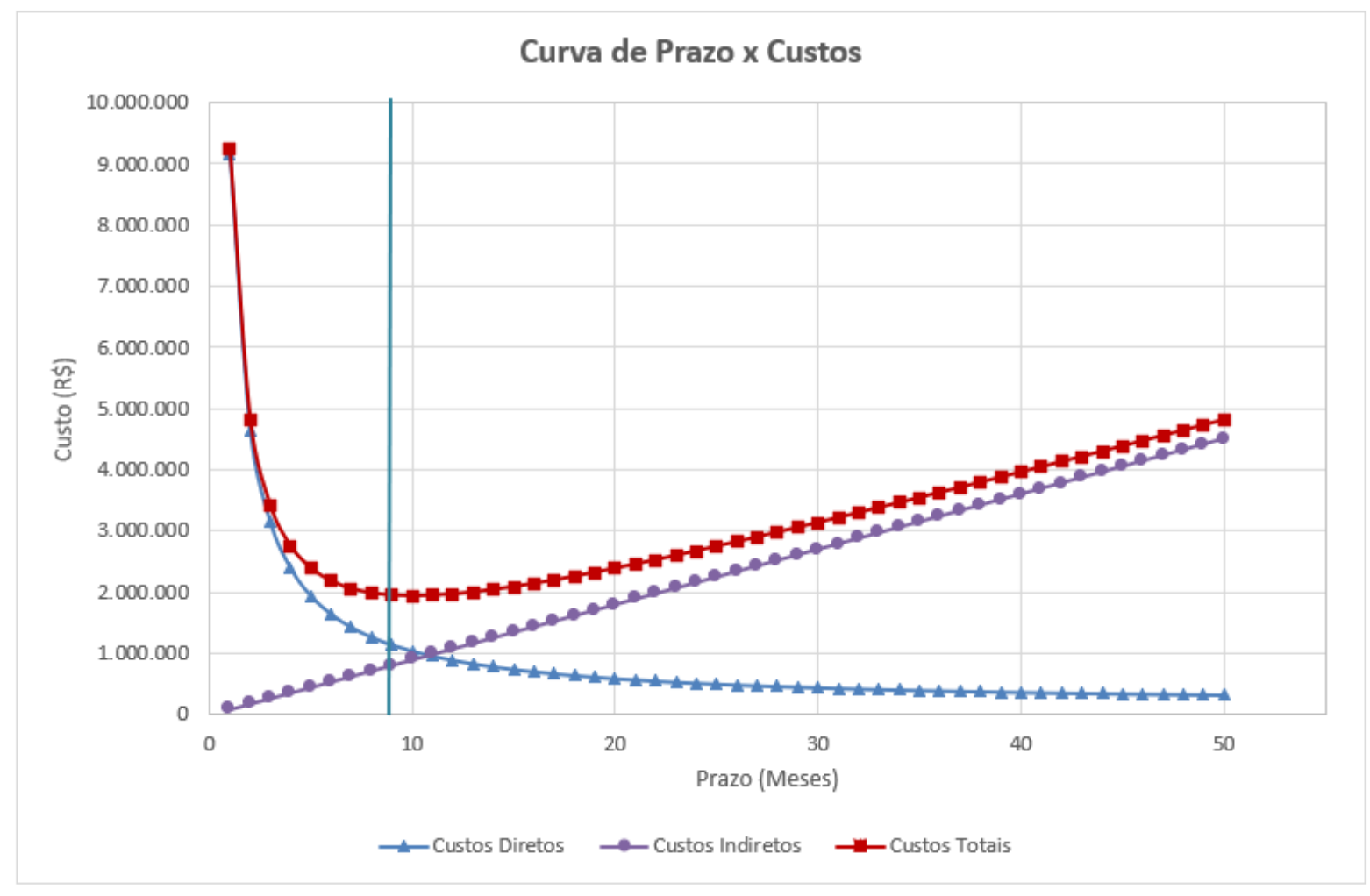

Gráfico 1 - Curva de prazos x custos totais do projeto - Adaptado de Hirschfeld (1978)

É em torno da hipótese de que em um determinado prazo - prazo ótimo, a somatória entre os custos diretos e indiretos totalizaria o menor valor possível para o projeto, que o trabalho pretende ser desenvolvido, tentando observar quais são os fatores fundamentais que influenciam a sua determinação, qual a sua flutuação, qual a sua variabilidade em diferentes tipos de projetos e, finalmente, quais os impactos das variações destes prazos.

O trabalho fundamenta-se nesse princípio e busca desenvolver um método que aborde os aspectos matemáticos das variações dos custos e prazos nos projetos, permitindo, de maneira simples, o cálculo do prazo ótimo do projeto. Sem dúvida, é uma inovação, uma vez que, diferentemente dos trabalhos que o autor pôde observar, o desenvolvimento sempre foi tratado de maneira genérica, apenas abordando essa possibilidade de maneira gráfica geral, ou, então, sendo feita através de abordagem de algoritmos complexos computacionais.

A origem da ideia de se criar este método teve início após o ano de 2012, enquanto o autor estudava alguns projetos de infraestrutura.

Dois fatores chamaram muito a atenção naquela época sobre o que vinha acontecendo no mercado da construção: a crise muito alta no setor e o nível de 
desconto dado pelas empresas vencedoras nos preços-base dos editais das licitações de obras públicas e privadas, chegando ao nível de 40\%. Desta maneira, um questionamento apareceu: como as empresas poderiam chegar a um nível tão elevado de desconto nesses editais, uma vez que todos os preços de editais públicos são balizados em composições públicas de preços: SIURB, SINAPI, CPOS, SICRO, e sendo que os editais privados também possuíam razoável margem de confiança em suas estimativas?

A pergunta não possui uma resposta única, há várias opções: redução das margens de lucro por parte das construtoras, erros nos quantitativos dos editais, corte de custos, reduções salariais, entre outras. Entretanto uma outra opção que o autor percebeu que vinha ocorrendo no mercado era a dos estudos de cenários nos orçamentos contemplando a redução ou o aumento do prazo dos projetos, a fim de se identificar um prazo "melhor" para gerar economia de custos e, consequentemente, maiores descontos, ou seja, indiretamente, por meio de iterações, as empresas estavam fazendo estudos da variabilidade clara presente no relacionamento entre custos e prazos.

Assim, veio a motivação do autor, a de estudar e tentar desenvolver um método que possa, de maneira mais sistemática e prática, encontrar esses parâmetros de variabilidade dos custos e prazos das obras.

A justificativa principal se dá ao fato da não existência de um método simplificado e prático que possibilite, de maneira simples, a identificação do prazo ótimo dos projetos em função dos custos.

Bressiani (2004), por exemplo, cita que se faz necessária a utilização de ferramentas rápidas que possibilitem a determinação dos custos, como a utilização de estimativas paramétricas para o fornecimento de valores com um nível de erro aceitável para a tomada de decisões iniciais do projeto.

Outras justificativas são originadas devido ao alto potencial econômico tanto do setor quanto do método, fato que pode ser visualizado a seguir.

O setor da construção, no ano de 2017, representou uma média de 4,3\% do valor mundial adicionado a todo Produto Interno Bruto (FEDERAL RESERVE BANK OF ST. LOUIS, 2018). Quando analisado o Brasil, este percentual alcança cerca de 5,2\% (CÂMARA BRASILEIRA DA INDÚSTRIA DA CONSTRUÇÃO, 2018). Ao avaliar que, em 2017, o PIB mundial foi de cerca de USD 80,6 trilhões de dólares (THE WORLD BANK, 2018), fica evidente o potencial financeiro do setor.

Pode-se dizer que, de uma forma direta ou indireta, um mecanismo mais científico, tecnológico e mensurável que aborde a relação entre os prazos e custos dos projetos de construção poderia ter alta influência e grande potencial financeiro.

O setor da construção, no que tange às etapas de orçamentação e planejamento, é caracterizado por um certo empirismo, culminando na maioria das vezes em uma falta de confiabilidade nas estimativas de prazos, custos e resultados dos projetos.

Librelotto e Lopes (2003) citam os riscos gerados nos projetos devido aos erros que chegam de $20 \%$ a $30 \%$ durante a sua análise de viabilidade.

A maioria das análises feitas durante as etapas de orçamentação e planejamento dos projetos de construção utiliza análises determinísticas, que se baseiam em 
parâmetros médios observados em projetos similares ou que são coletados em materiais técnicos. Tal fato mostra uma falta de adaptação do setor da construção para novas tecnologias já disponíveis, visto que a maior parte da indústria de bens de consumo e suprimentos já não utiliza mais análises determinísticas para seus planejamentos e suas orçamentações, mas, sim, análises estocásticas que possibilitam fazer uma análise muito mais detalhada e balizada em probabilidade e estatística.

Esse empirismo, alinhado à falta de pesquisa e desenvolvimento de novas tecnologias, torna o setor subjetivo e frágil, dando margem para inúmeros problemas setoriais que vêm sendo facilmente observáveis nos últimos anos. Um grande exemplo deles são as inúmeras falhas nas etapas de contratação e os gastos excessivos dos projetos que culminam em aditivos contratuais.

Apesar dos grandes problemas existentes, o meio ao qual a indústria da construção está imersa tem se mostrado mais favorável para que ocorram inovações tecnológicas, melhorias organizacionais e culturais em toda a sua cadeia produtiva, com possível economia nos processos e na geração de valor.

Umas das inovações que se mostra possível é justamente a abordagem mais técnica e científica das questões de interações entre os custos e os prazos dos projetos.

Diversos pesquisadores já se atentaram para a relevância e importância do tema, destacando-se Feng, Lui, Burns, Klansek, Trivedi e Namdev.

Para Feng, Liu e Burns (2000), a maior dificuldade para o cálculo do menor custo do projeto é devida às centenas de atividades existentes e às várias opções de completá-las utilizando diferentes quantidades de trabalhadores e equipamentos. Tal fato cria um problema clássico combinatório para os orçamentistas ao tentar identificar qual a melhor quantidade de trabalhadores e equipamentos a fim de se obter o menor custo final.

Uma abordagem sobre a predeterminação dos prazos de projetos pode ser verificada no trabalho de Hari (2017). Porém falta principalmente uma análise mais detalhada de quais são os elementos fundamentais que fazem com que os custos diretos e indiretos variem com o prazo dos projetos.

Segundo os autores Agyei (2015), Khang e Myint (1999), citados por Hari (2017), as principais restrições em um projeto de construção são tempo, custo e recursos do projeto. Geralmente os projetos de construção são complexos por natureza e afetados por atrasos no tempo. As principais razões para o atraso são a estimativa imprecisa, falhas de design, problemas de terra, licitação e atraso no fluxo financeiro, atrasos de pagamento, inexperiência, falta de coordenação e mudança no escopo do trabalho. Assim, a administração enfrenta problemas de relação entre tempo e custo.

A questão da variabilidade entre custos e prazos, a abordagem sobre a dúvida existente na determinação do cronograma ou prazo ideal para o projeto e também a possibilidade do estabelecimento de um algoritmo adequado para este cálculo são desenvolvidas nas citações de Klansek e Trivedi, conforme a seguir.

O agendamento econômico é um dos aspectos mais importantes do gerenciamento de projetos de construção. Os métodos tradicionalmente usados para 0 planejamento econômico de projetos no gerenciamento de construção incluem o 
Método do Caminho Crítico (CPM) ou a Técnica de Avaliação e Revisão do Programa (PERT) combinada com o procedimento de tentativa e erro. Dessa forma, os cronogramas de projeto com boa relação custo-benefício são alcançados em uma análise demorada de custo-duração de várias alternativas para horários de início e duração das atividades do projeto de construção. No entanto, existe sempre a dúvida sobre se o cronograma do projeto obtido é ideal ou não. Para superar as desvantagens mencionadas, vários métodos de otimização diferentes estão sendo propostos para a otimização de custos dos cronogramas do projeto (KLANŠEK; PŠUNDER, 2010).

Considerando-se a análise do balanço entre todas as atividades do projeto, pode ser desenvolvida a relação entre a duração do projeto e o custo total da construção. $O$ custo direto é a soma de todo o custo de construção das atividades, e o custo indireto são os custos necessários para o andamento do projeto. Portanto o custo total da construção do projeto pode ser calculado adicionando-se o custo direto ao custo indireto. Quando a duração do projeto é reduzida, o custo total torna-se bastante alto, e, à medida que a duração aumenta, o custo total também aumenta, mas a uma taxa inferior. Consequentemente esses problemas de tempo-custo na construção permitem desenvolver um algoritmo adequado que pode estabelecer uma relação de otimização (TRIVEDI; NAMDEV, 2015).

Por isso a estruturação de um método de estudo do relacionamento entre custo e prazo dos projetos de construção a fim de se determinar um prazo ótimo, no qual os custos finais sejam reduzidos, justifica-se claramente. Método que pode modernizar e amparar a confiabilidade dos projetos de construção de modo mais preciso, técnico e científico, além de poder apoiar futuros trabalhos e pesquisas relacionados a esta temática.

\subsection{OBJETIVOS}

O presente trabalho tem por objetivo desenvolver um método prático para a avaliação do prazo ótimo teórico de um projeto, prazo que resulte em menores custos totais e que possibilite em toda etapa de planejamento e gestão dos projetos a obtenção de um ponto de partida para a orçamentação, possibilitando também uma avaliação mais detalhada de todos os fatores que, direta ou indiretamente, impactam a relação entre os prazos e os custos. Os usuários imediatos do método proposto são as empresas de construção.

No Quadro 1, estão descritos os objetivos principais e específicos do trabalho.

Quadro 1 - Objetivos do trabalho

\begin{tabular}{|l|l|}
\hline Item & Descrição \\
\hline $\begin{array}{l}\text { Desenvolver método para calcular o prazo } \\
\text { ótimo teórico de projetos }\end{array}$ & Objetivo Principal \\
\hline $\begin{array}{l}\text { Evidenciar fatores que influenciam o cálculo } \\
\text { do prazo ótimo teórico e seu } \\
\text { comportamento }\end{array}$ & Objetivo Específico \\
\hline
\end{tabular}


Avaliar o comportamento do método

desenvolvido em diferentes tipos de projeto

Objetivo Específico

Fonte: Autor

\subsection{METODOLOGIA PARA O DESENVOLVIMENTO DO TRABALHO}

Trata-se de um trabalho teórico-prático elaborado por meio de simulações numéricas, estudos de caso e revisão das etapas de orçamentação de obras e dos aspectos de variabilidade entre custos e prazos.

A confirmação dos resultados teóricos é obtida através de estudos de caso em projetos existentes no setor da construção. Computando, assim, os benefícios que podem ser gerados direta e indiretamente e observando quais são os fatores fundamentais que influenciam a determinação do tempo ótimo, qual a sua flutuação e, finalmente, qual a sua variabilidade em dois tipos diferentes de projeto.

No Quadro 2, são descritos os objetivos e as suas metodologias de aplicação.

Quadro 2 - Metodologia do trabalho

\begin{tabular}{|l|l|l|l|}
\hline Objetivos & Metodologia & Resultado & Confirmação \\
\hline $\begin{array}{l}\text { Desenvolver método } \\
\text { para calcular o prazo } \\
\text { ótimo teórico de } \\
\text { projetos }\end{array}$ & $\begin{array}{l}\text { Revisão bibliográfica e } \\
\text { pesquisa dos modelos } \\
\text { existentes a fim de } \\
\text { desenvolver um } \\
\text { método mais } \\
\text { adequado, simples e } \\
\text { eficaz }\end{array}$ & $\begin{array}{l}\text { Descrição do método e e } \\
\text { como ele deve ser } \\
\text { aplicado nos projetos }\end{array}$ & $\begin{array}{l}\text { Comparação do método } \\
\text { do modelo teórico com } \\
\text { resultados obtidos em } \\
\text { simulações com projetos } \\
\text { reais }\end{array}$ \\
\hline $\begin{array}{l}\text { Evidenciar fatores que } \\
\text { influenciam o cálculo } \\
\text { do prazo ótimo teórico } \\
\text { e seu comportamento }\end{array}$ & $\begin{array}{l}\text { Revisão bibliográfica } \\
\text { do assunto, pesquisas } \\
\text { em campo, conversas } \\
\text { com profissionais da } \\
\text { área }\end{array}$ & $\begin{array}{l}\text { Obtenção dos fatores } \\
\text { que influenciam o } \\
\text { cálculo do prazo ótimo, } \\
\text { suas variabilidades e } \\
\text { pesos relativos }\end{array}$ & $\begin{array}{l}\text { Aplicação dos fatores } \\
\text { obtidos na concepção do } \\
\text { método desenvolvido e } \\
\text { confirmação através das } \\
\text { simulações com dados } \\
\text { reais e modelagem }\end{array}$ \\
\hline $\begin{array}{l}\text { Avaliar comportamento } \\
\text { do método } \\
\text { desenvolvido em } \\
\text { diferentes tipos de } \\
\text { projeto }\end{array}$ & $\begin{array}{l}\text { Estudos de caso em } \\
\text { diferentes tipos de } \\
\text { projeto, calculando, } \\
\text { assim, seus } \\
\text { respectivos prazos } \\
\text { ótimos e seus fatores } \\
\text { de influência }\end{array}$ & $\begin{array}{l}\text { Diferentes tipos de } \\
\text { dados tempo ótimo e } \\
\text { fatores que } \\
\text { influenciaram este } \\
\text { cálculo) para cada um } \\
\text { dos projetos }\end{array}$ & $\begin{array}{l}\text { Simulação com modelos } \\
\text { para validação }\end{array}$ \\
\hline
\end{tabular}

Fonte: Autor

A importância da aplicação do método proposto através de estudos de caso é de suma importância e se encaixa perfeitamente no contexto do trabalho. 
Yin (2005) cita que, em geral, estudos de caso representam a estratégia preferida quando se colocam questões do tipo "como" e "por que", quando o pesquisador tem pouco controle sobre os acontecimentos e quando o foco se encontra em fenômenos contemporâneos inseridos em algum contexto da vida real.

\subsection{ESTRUTURA E ETAPAS DE DESENVOLVIMENTO DO TRABALHO}

O trabalho está estruturado em cinco capítulos principais. O primeiro capítulo aborda os conceitos introdutórios, as justificativas, as motivações e os objetivos do trabalho. O segundo capítulo aborda a conceituação técnica dos orçamentos de obras e algumas particularidades das obras de construção. No terceiro capítulo, é feita uma revisão de trabalhos referentes ao tema e à descrição do método em si, e, no quarto capítulo, é feita a aplicação do método em dois modelos práticos. Finalmente, no quinto capítulo, são feitas as recomendações do método e as conclusões finais.

No Quadro 3, é abordado cada um dos resultados intermediários esperados para cada uma das etapas de desenvolvimento deste trabalho que estão embutidos nos capítulos desenvolvidos.

Quadro 3 - Atividades intermediárias x resultados esperados

\begin{tabular}{|c|c|c|}
\hline Item & Atividades & Resultados \\
\hline 1 & Revisão de conceitos fundamentais & $\begin{array}{l}\text { Revisão sucinta com os principais } \\
\text { conceitos exigidos para o entendimento } \\
\text { do método a ser desenvolvido }\end{array}$ \\
\hline 2 & $\begin{array}{l}\text { Determinação dos fatores que influenciam os } \\
\text { custos dos projetos }\end{array}$ & $\begin{array}{l}\text { Revisão bibliográfica e documental } \\
\text { contendo os fatores que influenciam os } \\
\text { custos do projeto de forma organizada }\end{array}$ \\
\hline 3 & $\begin{array}{l}\text { Elaboração de equacionamento fundamental para } \\
\text { a composição dos custos finais do projeto }\end{array}$ & $\begin{array}{l}\text { Organização de uma formulação } \\
\text { estruturada e sistemática contendo todos } \\
\text { os elementos previamente identificados }\end{array}$ \\
\hline 4 & $\begin{array}{l}\text { Tratativas matemáticas da equação para a } \\
\text { determinação do prazo ótimo teórico }\end{array}$ & $\begin{array}{l}\text { Determinação e aplicação de um modelo } \\
\text { matemático para encontrar prazo ótimo } \\
\text { teórico }\end{array}$ \\
\hline 5 & Descrição do método e da abordagem & $\begin{array}{l}\text { Relatório descritivo da concepção do } \\
\text { modelo e qual a sua abordagem para uso } \\
\text { e aplicação }\end{array}$ \\
\hline 6 & Exploração do potencial teórico do método & $\begin{array}{l}\text { Exploração de curvas para casos gerais, } \\
\text { correlacionamento de índices x curvas, } \\
\text { entre outros }\end{array}$ \\
\hline 7 & $\begin{array}{l}\text { Coleta de dados reais para a aplicação no } \\
\text { método desenvolvido }\end{array}$ & $\begin{array}{l}\text { Relatório contendo conjunto de dados } \\
\text { reais de um projeto de construção. }\end{array}$ \\
\hline 8 & $\begin{array}{l}\text { Emprego do método desenvolvido em projeto- } \\
\text { teste real }\end{array}$ & $\begin{array}{l}\text { Determinação do prazo ótimo teórico } \\
\text { utilizando o modelo desenvolvido } \\
\text { juntamente com os dados reais coletados } \\
\text { anteriormente }\end{array}$ \\
\hline
\end{tabular}




\begin{tabular}{|l|l|l|}
\hline 9 & Comparação dos resultados & $\begin{array}{l}\text { Análise comparativa entre prazo real } \\
\text { versus teórico e custos totais versus } \\
\text { custos teóricos }\end{array}$ \\
\hline 10 & $\begin{array}{l}\text { Conclusões finais e futuras aplicabilidades do } \\
\text { método desenvolvido }\end{array}$ & $\begin{array}{l}\text { Conclusões finais sobre o método } \\
\text { desenvolvido, abordagem de suas } \\
\text { limitações e pontos fortes, além da } \\
\text { descrição de possíveis aplicabilidades } \\
\text { futuras }\end{array}$ \\
\hline
\end{tabular}

Fonte: Autor

\subsection{CARACTERIZAÇÃO DO AUTOR}

A fim de caracterizar a origem da ideia sobre esta linha de pesquisa, é importante fazer uma caraterização da vida profissional e acadêmica do autor.

O autor do trabalho possui graduação em Engenharia Civil pela Universidade Federal de São Carlos, obtida em 2009, MBA Internacional em Gerenciamento de Projetos pela Fundação Getulio Vargas - FGV/University of California - UCI, obtida em 2012, além de alguns cursos de especialização na área de Supply Chain oferecidos por plataformas on-line do Massachusetts Institute of Technology - MIT, em 2016. Possui também algumas certificações profissionais de Gerenciamento de Projetos, como Project Management Professional - PMP, por PMI, Prince2 Foundation e Practitioner e MS - Managing Projects with Microsoft Project 2013.

Em sua carreira profissional de mais de 12 anos, pôde atuar em grandes projetos de construção e infraestrutura - aeroportos, estádios de futebol, pontes, metrô, estradas e prédios, atuando principalmente na área de planejamento, tecnologia (engenharia), PMO, orçamento e custos. 


\section{ORÇAMENTOS DE OBRAS DE CONSTRUÇÃO}

Para o desenvolvimento do método de cálculo do prazo ótimo do projeto de construção, a análise minuciosa dos inúmeros parâmetros do orçamento do projeto se faz necessária. Desta forma, para que seu entendimento seja mais simples, pretende-se estruturar seu desenvolvimento em diversas etapas de evolução gradual, concebendo desde uma revisão da concepção de orçamento de obras até finalmente a sua fundamentação detalhada. Abaixo, seguem os tópicos que serão tratados neste item:

- Concepção do orçamento de obras

- Particularidades dos cronogramas das obras: curva S de avanço físico

- Relação entre prazo e custos em projetos

\subsection{CONCEPÇÃO DO ORÇAMENTO DE OBRAS}

A elaboração de um orçamento para a determinação dos custos e resultados de uma obra ou projeto é uma atividade extremamente complexa, ela envolve a utilização de inúmeras variáveis e ferramentas: composições de serviços, levantamento de quantidades, elaboração de cronogramas, estimativas de custos indiretos, análise de riscos, entre outras.

Segundo Mattos (2006), o orçamento de uma obra não pode ser confundido com a orçamentação. O orçamento é o produto final do trabalho, já a orçamentação é o processo de determinação do orçamento.

Para as empresas ou pessoas que pretendem participar de atividades de construção, a elaboração de um bom orçamento se faz fundamental. Ele é o pontochave para que a parte interessada possua uma previsibilidade financeira: seus futuros custos, receitas e resultados.

Sua importância não se limita ao aspecto financeiro, um bom orçamento é fundamental para que a execução do projeto consiga ter planejamento e execução adequados e consiga dar ao executor as previsibilidades de prazo, pontos críticos de monitoramento e controle, necessidades temporais dos suprimentos e contratações, além de subsidiar a análise dos riscos envolvidos.

É importante salientar que a elaboração do orçamento não é uma atividade na qual se obtém um resultado exato, mas, sim, uma atividade de estimativa, basicamente um exercício de previsão de custos. Entretanto é de suma importância que as empresas, durante a etapa de orçamentação, nunca renunciem à melhor precisão possível, pois a precisão da etapa orçamentária é um dos fatores que mais contribuem para o sucesso do projeto.

O orçamento final basicamente se resume à somatória de todos os custos diretos e indiretos apurados nos levantamentos e estudos. De uma maneira simplificada, pode-se estimar o custo orçado pela Equação (1) e o valor de venda pela Equação 
(2). Um detalhamento mais aprofundado sobre os conceitos de custos diretos, indiretos e BDI será abordado nos itens 2.1.3.1, 2.1.3.2 e 2.1.3.3.

$$
\begin{gathered}
\text { Custo Orçado }=\sum_{i=1}^{n} \text { Custos Diretos }+\sum_{i=1}^{n} \text { Custos Indiretos } \\
\text { Preço de Venda }=\left(\sum_{i=1}^{n} \text { Custos Diretos }\right) \times(1+B D I)
\end{gathered}
$$

O preço de venda do projeto é obtido através da aplicação do BDI - Bonificação e Despesas Indiretas sobre o valor obtido no orçamento.

A composição do BDI, que é a outra parte importante do orçamento, deverá conter todos os itens relativos aos custos indiretos da Administração Central, eventuais taxas de riscos do empreendimento, custos financeiros do capital de giro, todos os tributos federais e municipais, custos de comercialização e pretensão ou previsão de lucro. (Tisaka 2006)

Segundo Tsaka (2006), o BDI é composto dos seguintes elementos:

- Despesas ou custos indiretos. São os custos da Administração Central diretamente ligados a uma determinada obra, tais como gerente de contrato, engenheiro fiscal e as respectivas despesas de viagem e alimentação e o rateio de todos os custos da Administração Central constituídos por salários de todos os funcionários, pró-labore de diretores, apoio técnico-administrativo e de planejamento, compras, contabilidade, contas a receber e a pagar, almoxarifado central, transporte de material e de pessoal, impostos, taxas, seguros etc.

- Taxa de risco do empreendimento

- Custo financeiro do capital de giro

- Tributos

- Taxa de comercialização

- Benefício ou lucro

O preço de venda, apesar de ser obtido através do orçamento, que é uma estimativa, é um valor exato e, na maioria das vezes, é fixado e regimentado por meio de um contrato entre o cliente e executor. Desta forma, a importância da precisão na elaboração do orçamento se mostra fundamental, além disso, é muito importante que, durante a execução do projeto, o executor sempre leve em consideração as premissas e diretrizes definidas no orçamento. 


\subsubsection{ATRIBUTOS DO ORÇAMENTO}

Os orçamentos possuem três principais atributos: aproximação, especificidade e temporalidade. Abaixo, segue a tratativa da aproximação e da especificidade.

\subsubsection{APROXIMAÇÃO}

O orçamento é baseado em previsões e estimativas feitas através de aproximações. Desta maneira, seu valor final não será exato, mas, sim, terá maior ou menor precisão, dependendo de qual nível de critério e estudo adotado.

Abaixo, seguem os principais itens que utilizam a aproximação:

\section{Mão de obra}

- Produtividade da Equipe - as produtividades das equipes de obra são estimativas adotadas por meio de observações de obras anteriores ou coletadas por meio de revistas ou órgãos especializados. Elas são médias horárias adotadas para cada função para desempenhar uma determinada atividade e são fatores que compõem as composições de custos. Por exemplo, um carpinteiro leva 2,5 horas para construir $1 \mathrm{~m}^{2}$ de forma. É perceptível que em muitos casos, dependendo do tipo de obra ou facilidade do serviço, este item pode variar para 2,0 horas ou até mesmo ir a 3,0 horas para a produção do serviço. A aproximação se faz necessária, pois nenhuma empresa é capaz de calcular um número exato de horas para diferentes tipos de serviço. Entretanto a precisão se faz necessária e, por isso, a importância de uma boa avaliação do orçamento.

- Encargos sociais e trabalhistas - os encargos sociais e trabalhistas são basicamente um conjunto de premissas e médias obtidas através de dados históricos e estatísticos para os valores inerentes aos trabalhadores devido às cargas tributárias e aos acordos sindicais e requerimentos legais. Alguns fatores são exatos, como, por exemplo, o cálculo do INSS, FGTS. Entretanto muitos outros são estimativas, como, por exemplo, acidentes de trabalho, rotatividade para aviso prévio e licenças obrigatórias.

\section{Material}

- Preço dos insumos - os preços de insumos são em sua grande maioria coletados com potenciais fornecedores através de cotações de preço. Entretanto os preços utilizados no orçamento são suscetíveis às mudanças de demanda de mercado, localização da obra, entre outros fatores. Desta 
forma, eles acabam sendo estimativas de um valor futuro, estimativas próximas, porém não imutáveis.

- Impostos - os impostos são estimados durante a fase de orçamentação. Para a execução de uma obra, há a incidência de diversos impostos federais, municipais e estaduais. Como exemplos, pode-se citar o ISS - Imposto Sobre Serviços, que é um tributo municipal, o ICMS - Imposto Sobre Circulação de Mercadorias e Serviços, que é estadual, e o PIS/COFINS - que é um tributo federal. Os impostos também podem ser suscetíveis às mudanças de legislação e, desta forma, também são estimativas para o futuro.

- Perda - as perdas são nada mais que percentuais arbitrados para cada um dos insumos que compõem o orçamento. As margens de perdas de cada material são estimativas adotadas pelos orçamentistas através de médias e indicadores de outros projetos. Um exemplo de perda pode ser o caso do aço, com perdas durante a fase de corte de dobra de, por exemplo, 5\%. É importante ressaltar que as perdas são inerentes à execução das atividades, já os desperdícios são gastos ou consumos que não agregam valor ao produto final do trabalho. Segundo Paliari (1999), as perdas seriam representadas pela diferença entre o consumo real de recursos envolvidos neste processo e a previsão de consumo preestabelecido, ou seja, homenshora previstos $\mathrm{x}$ homens-hora utilizados, consumo de material previsto $\mathrm{x}$ consumo de material realizado e consumo de energia previsto $x$ consumo de energia realizado.

- Reaproveitamento - são considerações de materiais que podem ser utilizados mais de uma vez durante a sua vida útil. Um dos exemplos de reaproveitamento é o caso de formas de chapa compensada, que podem ser reaproveitadas uma vez ou até mesmo três vezes. A estimativa depende do tipo de obra, e também são fatores arbitrados.

\section{Equipamento}

- Custo horário - o custo horário do equipamento é um parâmetro que pode ser estimado considerando-se a vida útil do equipamento, seus custos de manutenção operacional e preventiva, além dos custos da operação em si. Ele também é uma estimativa, pois depende de fatores variáveis.

- Produtividade - as produtividades dos equipamentos também são fatores estimados. Muitas vezes, em seus manuais técnicos, os equipamentos possuem suas capacidades produtivas, porém a consideração das produtividades dos equipamentos nos orçamentos depende muito de premissas de disponibilidade dos equipamentos, considerações de horas produtivas versus improdutivas, além da dificuldade do trabalho. Por exemplo, uma escavadeira pode escavar de $60 \mathrm{~m}^{3}$ a $120 \mathrm{~m}^{3}$ de solo por hora, dependendo se o solo é de classe I ou classe III. 


\section{Custos Indiretos}

- Pessoal - os orçamentistas elaboram um organograma e/ou histograma com as estimativas de necessidades da equipe indireta para a obra, incluindo nos custos os valores de encargos trabalhistas, alimentação, exames admissionais e demissionais, refeições, retorno à base, participação nos resultados, entre outros.

- Despesas gerais - as despesas gerais são estimativas de custos indiretos que a obra possuirá, dentre eles pode-se citar os custos de canteiros de obras e parques industriais, contas de água, luz, telefone, taxas bancárias, mobiliário para escritório, equipamentos de informática e softwares, equipamentos de uso indireto, como, por exemplo, gruas de apoio, geradores, serras, além de despesas de seguros.

- Imprevistos - os imprevistos são custos que os orçamentistas incluem como verbas para as incertezas que não podem ser estimadas, dentre eles pode-se citar as verbas de contingenciamento, os custos inerentes aos riscos de greve, chuva, inflação não coberta por reajustamento contratual, entre outros.

A partir da descrição de cada um dos fatores que compõem um orçamento de obras, fica claro que a orçamentação é uma atividade de estimativa e que envolve a adoção de inúmeras premissas. A precisão de cada orçamento envolve inúmeros fatores, e, de forma geral, quanto maior o nível de detalhe, maiores os esforços e custos para a sua elaboração. O método de cálculo do prazo ótimo pretende ser uma ferramenta que, com esforços reduzidos, possibilite melhorar a precisão dos orçamentos.

\subsubsection{ESPECIFICIDADE}

A especificidade basicamente pontua que cada orçamento de obra, por mais semelhante que seja, é uma atividade única e que não pode ser generalizada ou padronizada, mas, sim, apenas adaptada. Isto deve-se ao fato de que o orçamento de uma obra está ligado aos fatores externos que podem afetar muito seus valores e suas premissas.

Os fatores externos podem ser exemplificados conforme a seguir:

- Tipo de cliente - o tipo de cliente influencia o nível de segurança exigido, a adoção do uso de normas específicas, como, por exemplo, as normas ISO, e a obtenção de certificações como, por exemplo, LEED, fatores que podem incrementar em muito os custos. Outro exemplo pode ser as características financeiras dos clientes, que, devido ao risco de fluxo de caixa e condições de pagamento, podem fazer com que o projeto possua maiores riscos ou menores resultados. 
- Empresa - cada empresa tem sua política própria de gestão de obras, umas podem ter um efetivo indireto maior; outras, taxas de administração menores. Algumas podem fornecer melhores salários e condições para o seu efetivo, como, por exemplo, retornos à base mais frequentes, disponibilidade de carros, canteiro de obras mais elaborado. Outras podem adotar políticas sociais e usar softwares mais sofisticados. Tais fatores variam de empresa para empresa e são especificidades que devem ser ponderadas.

- Condições locais - a localização da obra muda muito os parâmetros do orçamento. O tipo de solo, as condições climáticas, a disponibilidade de mão de obra, a oferta de equipamentos, entre outros fatores, são condições que, com certeza, têm impacto relevante no orçamento.

\subsubsection{TEMPORALIDADE}

A temporalidade pontua que as questões temporárias dos orçamentos, ou seja, um orçamento elaborado há dez anos pode não ser mais válido para hoje. Tal fenômeno ocorre devido ao fato de que, conforme a variação do tempo, vários fatores mudam, por exemplo:

- Custos de insumos - os custos dos insumos não são estáticos no tempo, por exemplo, o diesel orçado para uma obra em 2009 não necessariamente terá o mesmo valor em 2019.

- Impostos e encargos - os impostos e encargos também variam, mudanças nas leis trabalhistas e mudanças de regimes tributários podem ocorrer com 0 passar do tempo.

- Metodologias construtivas - as metodologias empregadas há 15 anos não são as mesmas de hoje, diversas melhorias vêm ocorrendo, por exemplo, a redução do tempo de cura do concreto e o desenvolvimento de materiais mais leves e resistentes.

- Cenários financeiros e gerenciais - os cenários financeiros e gerenciais também mudam com o passar do tempo, as taxas de juros, inflação, taxas de atratividade são exemplos que sofrem variações no decorrer do tempo.

\subsubsection{ETAPAS DA ORÇAMENTAÇÃO}

As etapas fundamentais de orçamentação envolvem o estudo de diversas condicionantes ou condições de contorno, conforme abordado a seguir: 
- Leitura e interpretação do projeto e especificações técnicas - leituras dos projetos contendo plantas baixas, cortes, vistas, notas explicativas, tabelas, quadros, especificações técnicas, leis e normas.

- Leitura e interpretação do edital - interpretação do edital, no qual contém datas e marcos, penalidades, prazos, regime de preços, habilitação técnica, seguros, critérios de medição, regime de contratação e preços.

- Visita técnica - importante para tirar dúvidas, levantar diponibilidade de recursos, materiais e equipamentos, tirar fotos das frentes de serviços

- Identificação dos serviços - identificação e levantamento de todos os serviços necessários para que se conclua a obra.

- Levantamento de quantitativos - levantamento dos quantitativos dos serviços identificados através dos projetos.

- Discriminação dos custos diretos - separação de todos os custos diretos, ou seja, aqueles que representam os custos dos serviços levantados.

- Discriminação dos custos indiretos - separação dos custos indiretos, ou seja, aqueles que não estão diretamente associados ao campo, mas são fundamentais para o apoio e a conclusão da obra. Dentre eles estão engenheiros, mestres, contas de materiais e despesas de escritório.

- Cotação de preços - cotação de todos os insumos diretos e indiretos para a execução da obra com fornecedores e subcontratados.

- Definição de encargos sociais e trabalhistas - definição dos encargos sociais e trabalhistas que serão utilizados para a obra. Envolvem os aspectos de impostos que incidem sobre os custos de mão de obra, como, por exemplo, INSS, férias obrigatórias, $13^{\circ}$ salário, indenizações, entre outros.

- Definição da lucratividade - definição da lucratividade através da análise do retorno esperado pela empresa.

- Cálculo do BDI - cálculo do fator de majoração dos preços dos serviços para incluir as bonificações e despesas indiretas.

- Finalização do orçamento com planilha de venda - após o cálculo do BDI e dos custos dos serviços diretos, pode-se obter a planilha e/ou o preço de venda final da obra.

$\mathrm{Na}$ Figura 1, pode-se observar de maneira resumida as etapas fundamentais do orçamento. 


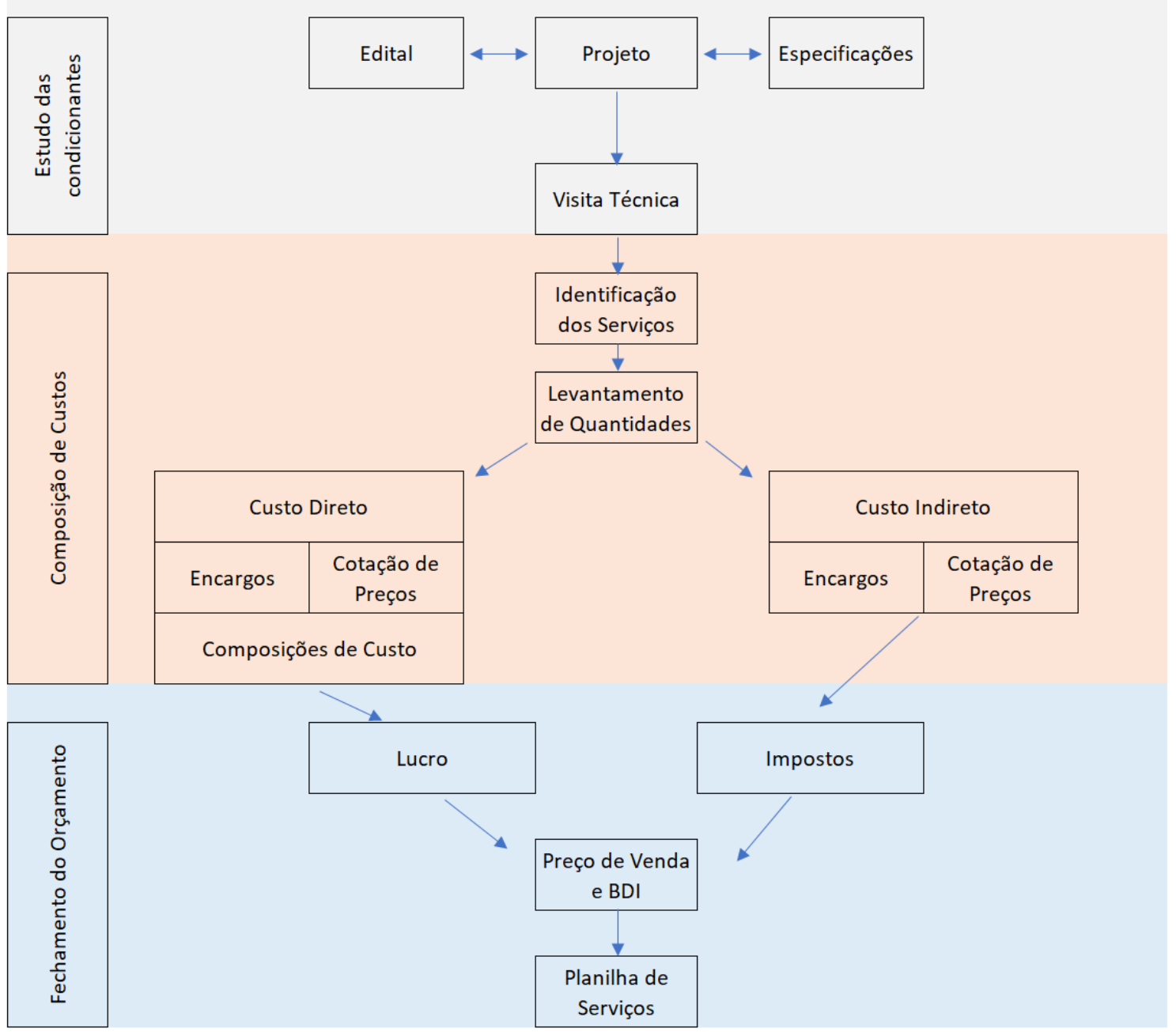

Figura 1 - Etapas fundamentais do orçamento. Adaptado - Mattos (2006)

\subsubsection{ABORDAGEM MATEMÁTICA DA ORÇAMENTAÇÃO}

Conforme já abordados nas Equações (1) e (2), os custos totais da obra se compõem pela somatória de todos os custos diretos e indiretos do projeto.

\subsubsection{CUSTOS DIRETOS}

O custo direto de uma obra é a somatória de todos os custos de materiais, equipamentos e mão de obra aplicados diretamente em cada um dos serviços na produção de uma obra ou edificação qualquer, incluindo-se todas as despesas de infraestrutura necessárias para a execução da obra (Tisaka, 2006).

Os custos diretos normalmente se dividem em três principais parâmetros: mão de obra, materiais e equipamentos. Para que o orçamentista consiga organizar 
informações, é usual que as quantidades de insumos e serviços sejam estimadas através de composições de serviços juntamente com planilhas de levantamento de quantidades.

Segundo Mattos (2006), as composições de custos listam todos os insumos que entram na execução de um determinado serviço, com suas respectivas quantidades e seus custos unitários e totais.

O Quadro 4 ilustra um modelo simples de composição de serviço.

Quadro 4 - Exemplo de composição de serviço

\begin{tabular}{|c|c|c|c|c|}
\hline Insumo & Unidade & Índice & $\begin{array}{c}\text { Custo Unitário } \\
(\mathrm{R} \$ / \text { Und })\end{array}$ & Custo Total \\
\hline Armador & $\mathrm{H}$ & 0,10 & 6,90 & 0,69 \\
\hline Ajudante & $\mathrm{H}$ & 0,10 & 4,20 & 0,42 \\
\hline Aço CA-50 & $\mathrm{Kg}$ & 1,10 & 2,90 & 3,19 \\
\hline Arame recozido & $\mathrm{Kg}$ & 0,03 & 5,00 & 0,15 \\
\hline \multicolumn{4}{|c}{ Total } \\
\hline
\end{tabular}

O Quadro 5 mostra um exemplo da composição de um dos serviços existentes em uma obra. Neste caso, é a composição do concreto estrutural usinado de $40 \mathrm{Mpa}$ incluindo o bombeamento.

Nota-se que a composição do serviço se divide em três subpartes:

- Equipamentos com o custo de $\mathrm{R} \$ 0,79 / \mathrm{m}^{3}$

- Mão de obra com o custo de $\mathrm{R} \$ 77,30 / \mathrm{m}^{3}$

- Materiais com o custo de $\mathrm{R} \$ 295,51 / \mathrm{m}^{3}$

Ao final, o valor do serviço fica em $R \$ 373,59 / \mathrm{m}^{3}$. Além disso, a composição do serviço se separa em:

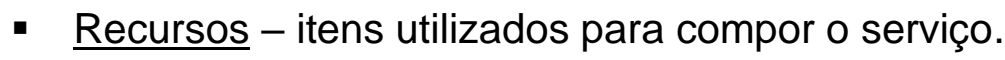

- Unidade - unidade utilizada para cada um dos recursos.

- Coeficiente - um dos itens mais importantes, no qual o orçamentista estima as produtividades de cada um dos recursos para determinado serviço.

- Valor unitário - é o custo unitário do recurso.

- Valor parcial - é o produto entre o custo unitário e o coeficiente de cada recurso. 
Quadro 5 - Composição de Serviço - Concreto $40 \mathrm{Mpa}$

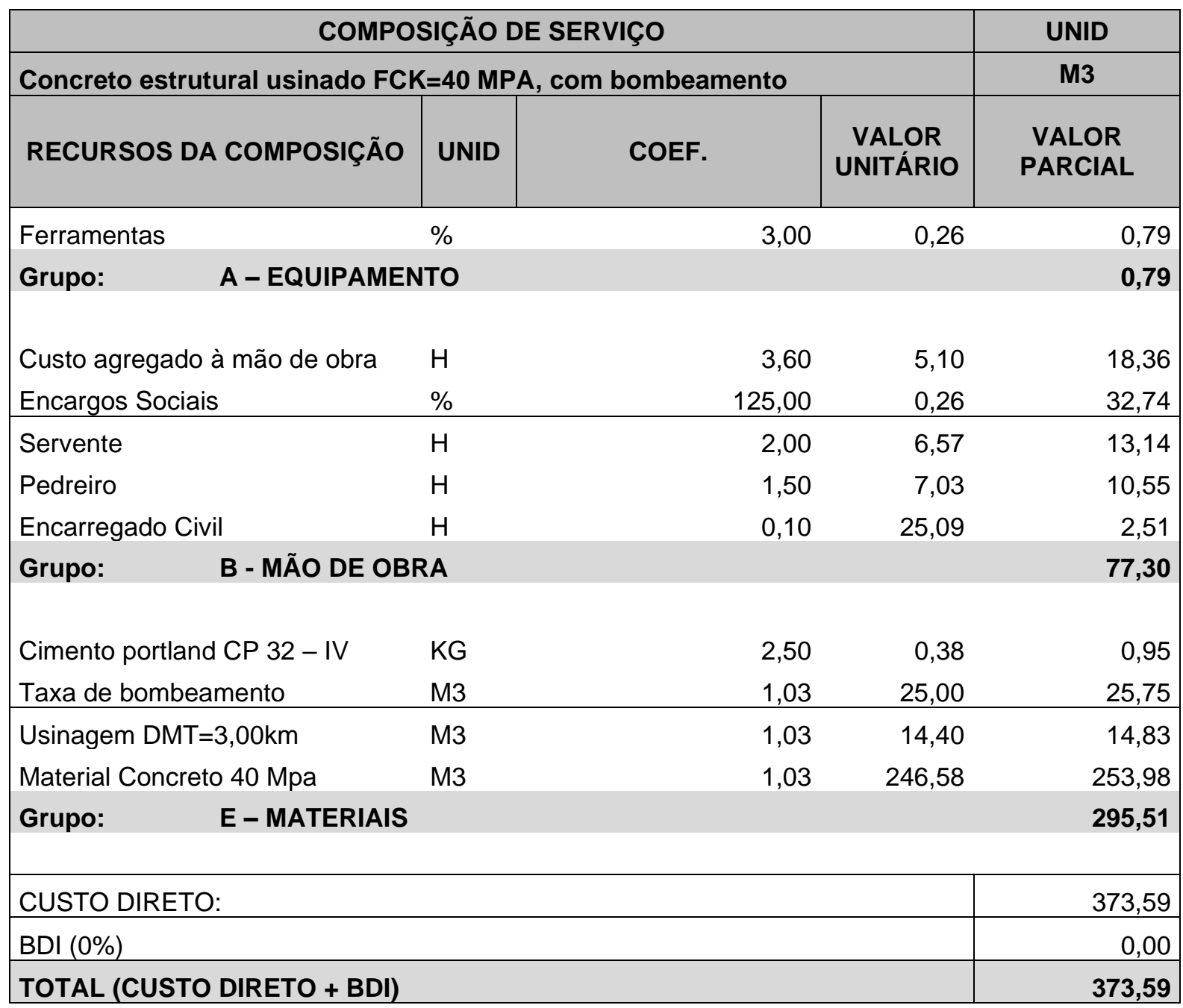

A planilha de levantamento ou estimativas de quantidades é onde as quantidades de projeto são organizadas de maneira estruturada e de fácil compreensão.

A partir destes dois elementos, quantidades de serviços e composições, pode-se gerar o Quadro 6, no qual cada uma das quantidades estimadas é multiplicada pela sua respectiva composição, de maneira que, ao final, pode-se gerar as estimativas de todos os custos diretos.

Como exemplo, pode-se calcular o custo direto do Item 2 - Concreto estrutural usinado Fck $40 \mathrm{Mpa}$ do Quadro 6. O quantitativo estimado é de $8.720 \mathrm{~m}^{3}$, o valor unitário conforme a composição do Quadro 5 é de $R \$ 373,59 / \mathrm{m}^{3}$. Desta forma, ao final, pode-se chegar ao custo direto total multiplicando estes dois fatores, resultando, assim, em $\mathrm{R} \$ 3.257 .751$.

De maneira análoga, pode-se calcular apenas os valores de mão de obra que certo serviço possui. Por exemplo, considerando a mesma quantidade do ltem 2 Concreto estrutural usinado Fck $40 \mathrm{Mpa}$ do Quadro 6, pode-se calcular que o valor de mão de obra gasto seria de $8.720 \mathrm{~m}^{3}$ multiplicados pelo valor unitário da mão de obra conforme o da composição do Quadro 5 , que é de $R \$ 77,30 / \mathrm{m}^{3}$. Desta forma, 
chegando ao final em um custo direto total de mão de obra deste serviço em $\mathrm{R} \$$ 674.056 .

Quadro 6 - Planilha de levantamento x composições de custo

\begin{tabular}{|c|c|c|c|c|c|}
\hline Item & Serviço & Unidade & Quantidade & $\begin{array}{l}\text { Valor } \\
\text { Unitário }\end{array}$ & Valor Total \\
\hline 1 & $\begin{array}{l}\text { Fornecimento, preparo e colocação de } \\
\text { Aço CA-50, inclusive mão de obra }\end{array}$ & KG & 1.263 .727 & 4,29 & 5.417 .724 \\
\hline 2 & $\begin{array}{l}\text { Concreto estrutural usinado } \mathrm{FCK}=40 \\
\text { MPA, com bombeamento }\end{array}$ & M3 & 8.720 & 373,59 & 3.257 .751 \\
\hline 3 & $\begin{array}{l}\text { Esc. carga transp. mat } 1^{\text {a }} \text { cat dmt } 3000 \\
\text { a } 5000 \mathrm{~m} \mathrm{c/e}\end{array}$ & M3 & 660.641 & 4,22 & 2.785 .064 \\
\hline 4 & $\begin{array}{l}\text { Fornecimento, preparo e colocação } \\
\text { formas Aço CA- } 50\end{array}$ & KG & 539.544 & 4,49 & 2.424 .117 \\
\hline 5 & $\begin{array}{l}\text { Fornecimento, preparo e colocação de } \\
\text { Aço CA-50, inclusive mão de obra }\end{array}$ & KG & 396.143 & 5,32 & 2.109 .264 \\
\hline 6 & 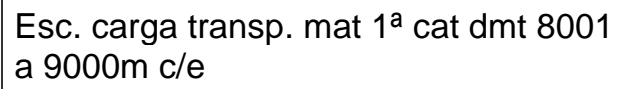 & M3 & 223.283 & 7,09 & 1.583 .768 \\
\hline 7 & Forma de placa compensada resinada & M2 & 58.384 & 22,29 & 1.301 .318 \\
\hline 8 & $\begin{array}{l}\text { Compactação de aterros a } 100 \% \\
\text { proctor normal }\end{array}$ & M3 & 587.781 & 2,08 & 1.223 .997 \\
\hline 9 & Sub-base de Brita Graduada & M3 & 5.936 & 158,36 & 940.121 \\
\hline 10 & $\begin{array}{l}\text { Concreto estrutural usinado } \mathrm{FCK}=40 \\
\text { MPA, com bombeamento }\end{array}$ & M3 & 2.483 & 373,59 & 927.785 \\
\hline
\end{tabular}

A elaboração dos custos diretos pode ser exemplificada pelo somatório das Equações (3), (4) e (5):

$$
\begin{aligned}
M O_{o} & =\sum_{i=1}^{n}\left(\text { CompMO }_{i} \times Q t d e_{i}\right) \\
\text { Mat }_{\mathrm{o}} & =\sum_{\mathrm{i}=1}^{\mathrm{n}}\left(\text { CompMat }_{\mathrm{i}} \times \mathrm{Qtde}_{\mathrm{i}}\right)
\end{aligned}
$$




$$
\mathrm{Eq}_{\mathrm{o}}=\sum_{\mathrm{i}=1}^{\mathrm{n}}\left(\mathrm{CompEq}_{\mathrm{i}} \times \mathrm{Qtde}_{\mathrm{i}}\right)
$$

Onde:

$M O_{o}-$ Custos totais de Mão de Obra Direta

CompMO $_{i}$ - Custos do item de Mão de Obra dentro de cada composição $i$ do projeto Mat $_{o}$ - Custos totais de Materiais Diretos

CompMat $_{\mathrm{i}}$ - Custos do item de Materiais dentro de cada composição $i$ do projeto

$E q_{o}$ - Custos totais de Equipamentos Diretos

CompEq $_{\mathrm{i}}$ - Custos do item de Equipamento dentro de cada composição i do projeto

Qtde $_{i}-$ Quantitativo de cada item i do projeto

\subsubsection{CUSTOS INDIRETOS}

São os custos específicos da Administração Central diretamente ligados a uma determinada obra, tais como gerente de contrato, engenheiro fiscal e as respectivas despesas de viagem e alimentação (Tisaka, 2006).

Os custos indiretos podem ser divididos em mão de obra indireta, despesas gerais e imprevistos. Normalmente, durante a orçamentação, eles são estimados da seguinte forma:

- Mão de obra gerencial - é equalizada de acordo com organogramas e histogramas de necessidades de recursos durante o tempo, pode ser aproximada para verbas mensais.

- Custos gerenciais - são custos de contas de consumo como água, energia, despesas de canteiro, materiais de escritório, custos advocatícios, despesas bancárias, custos de EPIs, treinamentos, exames médicos, entre outros. Usualmente também são estimados em verbas mensais.

- Riscos e imprevistos - são verbas gerenciais que são utilizadas como reservas de custo para itens que são extremamente difíceis de se mensurar durante o orçamento, como, por exemplo, greves, inflação, reajustamentos não cobertos pelo cliente, entre outros. Normalmente uma verba geral é provisionada para o projeto como um todo e direcionada para o final do projeto.

- Mobilização - é uma despesa de maior porte, geralmente inclui os custos de canteiro de obras, parque industrial, transporte dos equipamentos para a 
obra, equipamentos de informática, entre outros. Normalmente são verbas que incidem no início da obra.

Desta forma, de maneira matemática, pode-se dizer que a elaboração dos custos indiretos pode ser exemplificada pelas Equações ou Igualdades (6), (7) e (8), em que a Equação (6) compõe a verba de mobilização, a Equação (7) compõe os riscos e imprevistos e a Equação (8) compõe os custos mensais da obra.

$$
\begin{gathered}
C I_{M o b}=C I_{\min } \\
C I_{R}=C I_{R} \\
C I^{\prime}{ }_{t}=C I_{\text {mensal }}
\end{gathered}
$$

Onde:

$C I_{M o b}$ - Verba de mobilização sendo $C I_{\min }$ o valor mínimo de mobilização

$C I_{R}-$ Verba contemplando riscos, imprevistos e contingenciamento

$\mathrm{CI}^{\prime}{ }_{t}-$ Verba mensal contemplando custos indiretos médios mensais

Ao final, chega-se aos custos indiretos totais na Equação (9):

$$
C I_{0}=C I_{M o b}+C I_{R}+C I^{\prime}{ }_{t} \times t
$$

Onde:

$C I_{0}-$ Custos Indiretos totais

\subsubsection{CUSTOS TOTAIS}

Os custos totais podem ser dados pela Equação (10), que compõe a somatória de custos indiretos e diretos:

$$
C T_{t}=\left(M O_{o}+M a t_{o}+E q_{o}+C I_{o}\right)
$$

Onde:

$C T_{t}-$ Custos Totais 


\subsection{PARTICULARIDADES DOS CRONOGRAMAS DAS OBRAS: CURVA S}

As obras de Construção Civil têm inúmeras atividades, recursos físicos e financeiros para ser manejados e gerenciados durante o cronograma do projeto. Todos estes itens ocorrem de forma simultânea e envolvem uma grande complexidade. Em uma análise mais apurada das variabilidades dos recursos do projeto versus o cronograma, fica perceptível que tais fatores não ocorrem de forma linear, os projetos de construção possuem uma característica de ter um início mais lento, uma progressão mais acentuada e um encerramento também lento.

Uma forma bastante aceita de se representar esta característica específica de progressão das obras é através da Curva de Gauss, conforme representada pelo Gráfico 2 - Curva Normal. Quando esta curva é representada de forma acumulada, ela configura uma formatação em formato de "S" e é popularmente nomeada como curva S.

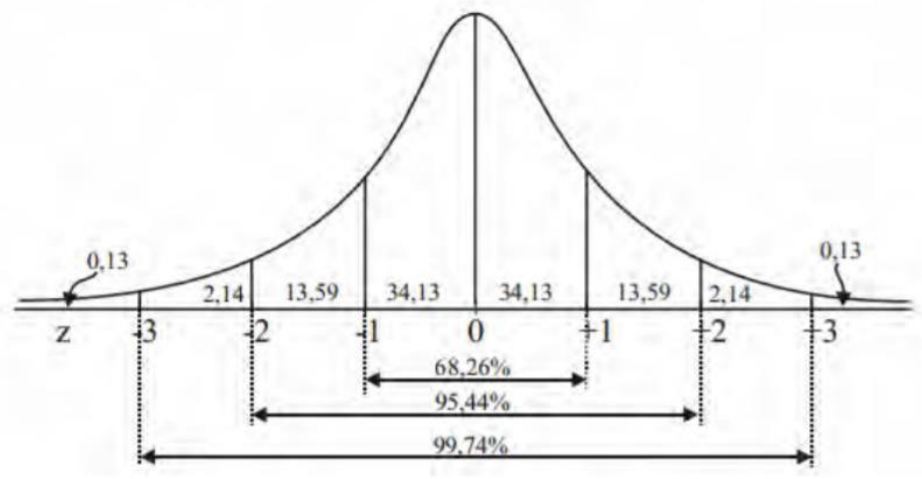

Gráfico 2 - Curva Normal. Caire (2013)

A curva $S$ é extremamente importante para a orçamentação de obras, sendo utilizada inclusive para as estimativas de avanço físico, de custos e de receitas.

Segundo Mattos (2010), uma maneira simplificada de se estabelecer a curva S para o projeto é pela Equação (11).

$$
\%_{\text {Acum }}(n)=1-\left[1-\left(\frac{n}{N}\right)^{\log I}\right]^{s}
$$

Neste caso, n é o número de ordem do período do projeto, $\mathrm{N}$ é o prazo total do projeto, I é o ponto de inflexão da curva e s é o coeficiente de forma que depende do ritmo e das particularidades da obra.

O desenvolvimento desta equação é de extrema importância para este trabalho, pois é por meio dela que será possível a determinação do fator de pico médio K, que será abordado adiante. 


\subsection{RELAÇÃO TEMPO-CUSTO EM PROJETOS}

O relacionamento entre os custos e prazos de projetos tem sido objeto de trabalho de grande parte dos pesquisadores da área. Os trabalhos desenvolvidos possuem duas vertentes principais: (i) elaboração de softwares iterativos para a determinação da curva de relacionamento entre custos e prazos e (ii) aplicação de análises de crash time fundamentadas apenas em algumas atividades selecionadas. Ambas fazem estimativas da variação dos custos de cada atividade em função do tempo, de forma bastante empírica ou não detalhada, focando principalmente a curva e os cálculos, e nas quais os fatores geradores da curva e as implicações de cada um.

Define-se a análise de crash time como uma etapa de orçamentação que pode ser replanejada a partir das relações entre custos e prazos do projeto, considerando-se que as características específicas do produto final, como qualidade e desempenho, sejam mantidas. Esta análise tem como objetivo possibilitar a análise de variação dos custos com a redução do prazo de entrega.

Usualmente, durante estas análises, apenas as atividades pertencentes ao caminho crítico do projeto são utilizadas, de forma que as reduções-limite de prazo de cada uma delas e os seus impactos nos aumentos de custos são computados.

Kelly (2009) aponta alguns parâmetros de variação durante uma análise de crash time:

- Aumento de horas extras

- Alocação de recursos adicionais para atividades específicas

- Contratação de recursos adicionais

- Pagamentos de incentivo para que as atividades sejam feitas mais rapidamente

- Contratação de terceirizados adicionais para reduzir os prazos das atividades

Kelly (2009) exemplifica uma curva típica entre custos e prazos, conforme o Gráfico 3. Ela aponta para a característica de correlação negativa entre os fatores.

Pela curva, o projeto inicialmente tem um prazo de 30 semanas da figura, e seu custo está em U\$60.000. Quando as atividades são aceleradas de forma que o prazo total se reduza a 20 semanas o custo aumenta para $U \$ 80.000$. Quando o prazo é reduzido para apenas 15 semanas, o custo aumenta para $U \$ 150.000$.

A partir desta redução de prazo para 15 semanas, definido como o ponto de máximo trade-off entre custos e prazos, nenhuma redução de prazos pode ser ganha. Uma razão desta particularidade é que o projeto já estaria com seu caminho crítico com os prazos reduzidos ao máximo possível ou em seu crash time. 


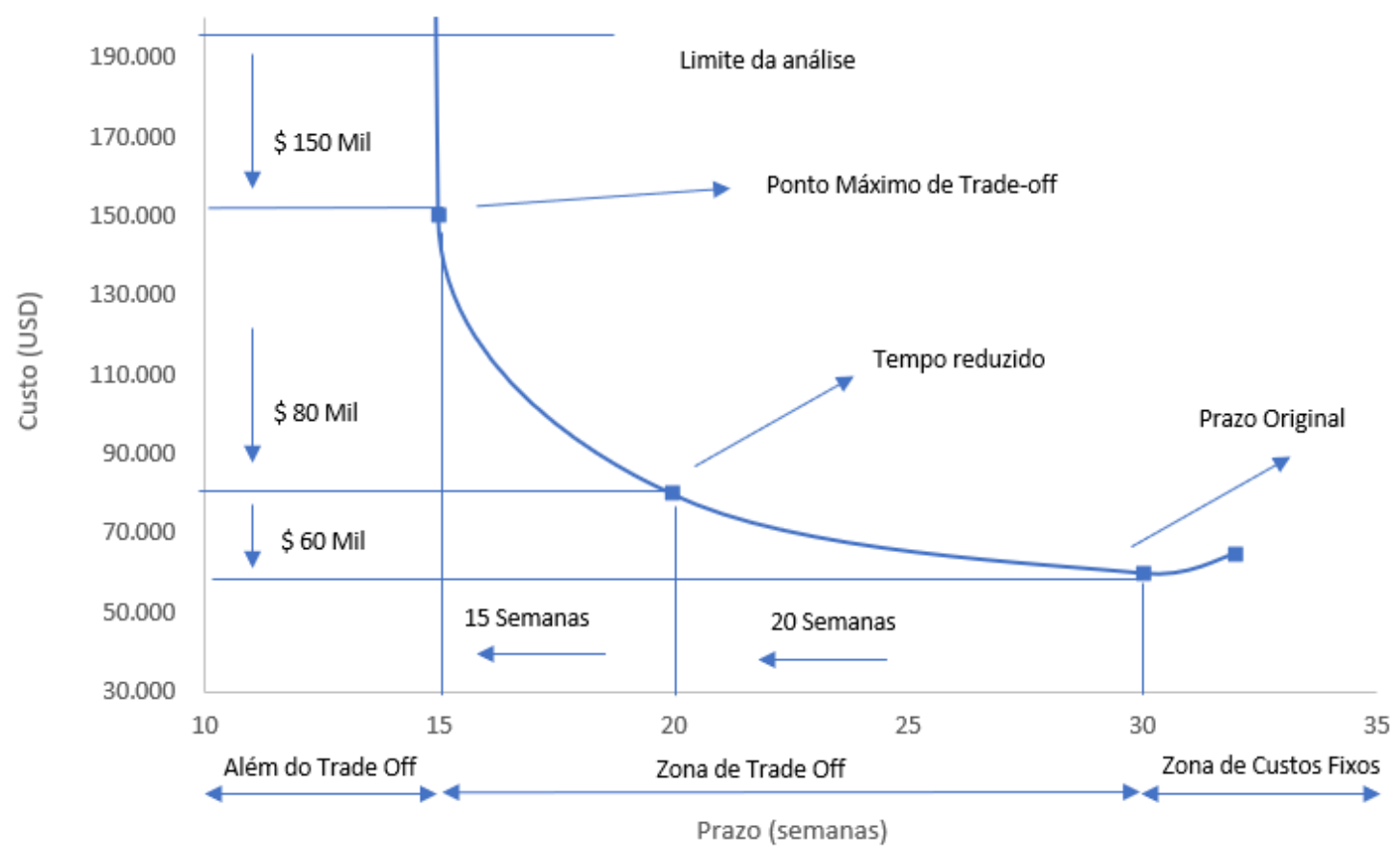

Gráfico 3 - Curva típica custos x prazo. Adaptado - Kelly (2009)

A conceituação do crash time é importante para este trabalho por três fatores principais:

- Mostra que as análises de prazo de projetos possuem limites de redução, possivelmente limites tecnológicos.

- Mostra a correlação negativa entre custos e prazos de projetos.

- Mostra que certas análises utilizadas hoje não consideram todos os parâmetros de projeto para análises, neste caso, por exemplo, apenas as atividades do caminho crítico são utilizadas.

No trabalho de Feng (1997), são apontadas as características de comportamento entre os custos e prazos de projetos, conforme o Gráfico 4. 


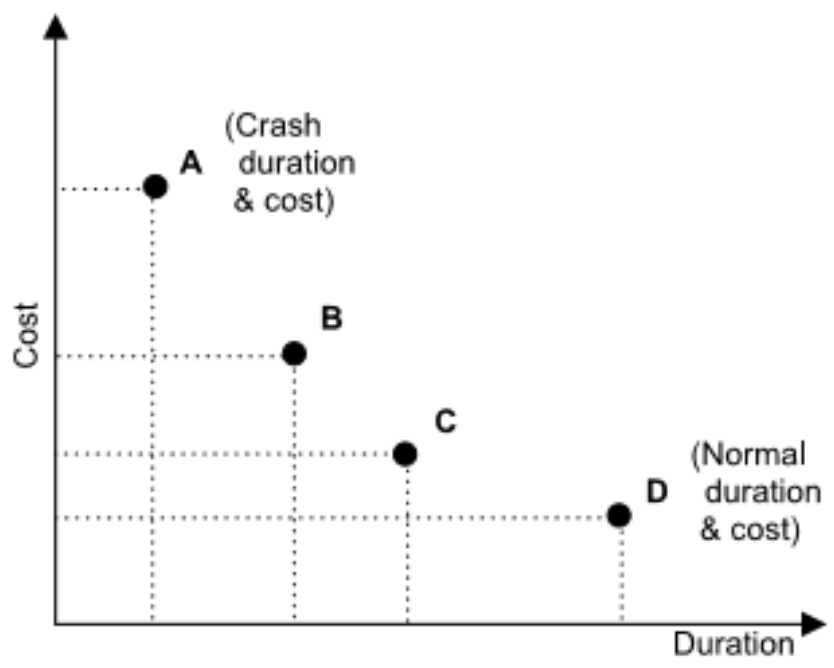

Gráfico 4 - Curva típica custos x prazo (Adaptado). Fonte: Feng (1997)

Foram feitos modelos computacionais com diversas iterações a fim de se obter as curvas de trade-off entre prazos e custos, conforme o Gráfico 5.
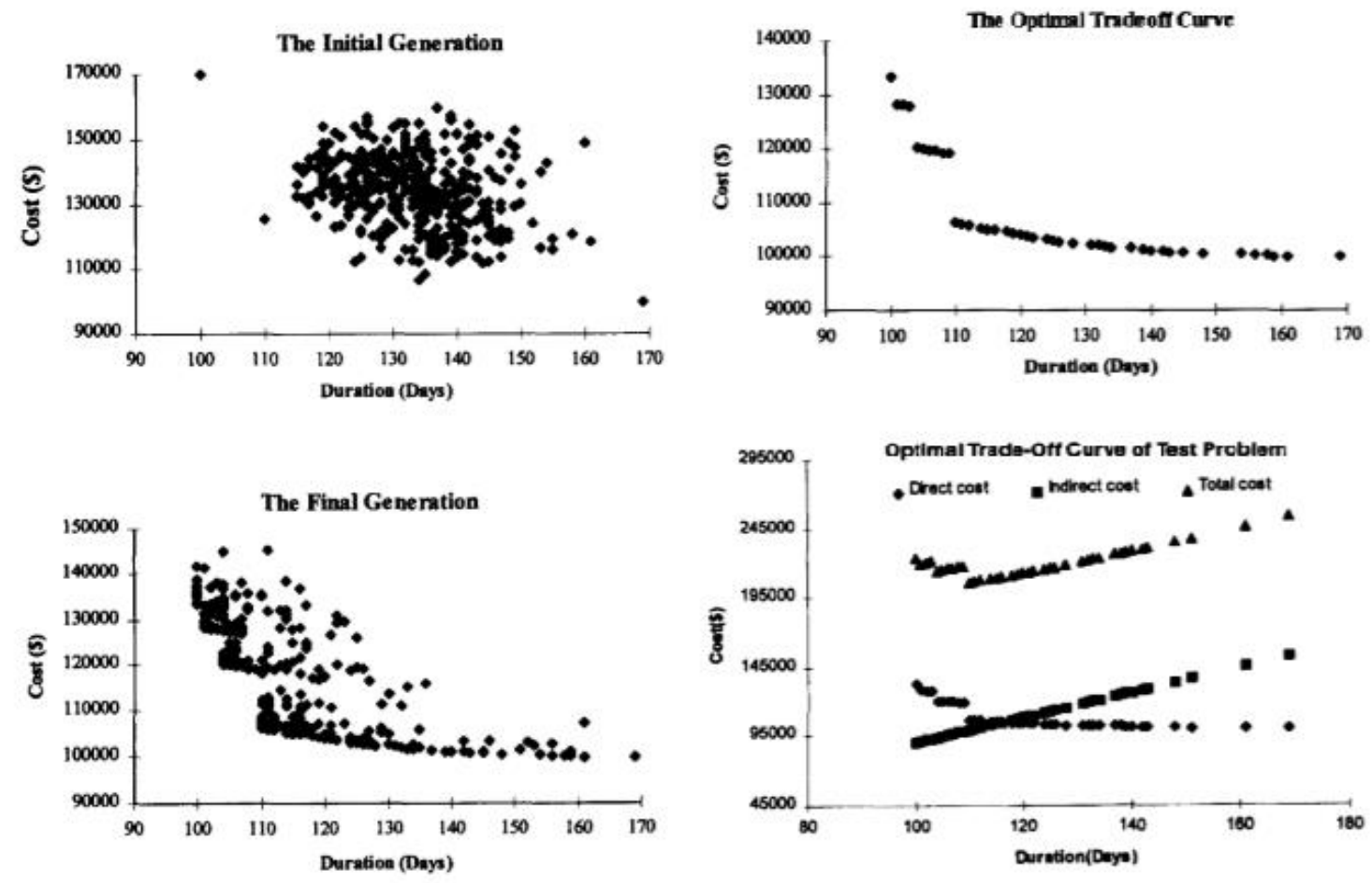

Gráfico 5 - Resultados custos x prazo utilizando algoritmos genéricos. Fonte: Feng (1997)

O enfoque estava principalmente na apuração técnica da funcionalidade de aplicação do algoritmo, sendo assim, os parâmetros dos valores dos custos e suas variações, conforme os prazos, não são abordados em detalhe e sugerem, de certa 
forma, uma arbitrariedade na parametrização dos valores, já que o enfoque era a sistematização e aplicação do algoritmo.

No Quadro 7, pode-se observar que, para cada uma das atividades, existem quatro possibilidades de duração e os respectivos custos para cada uma delas. É notável que este resultado somente foi possível porque foi definido que, conforme as durações aumentam os custos, eles ficam estimados em valores mais baixos.

Quadro 7 - Valores dos custos x prazos utilizados no algoritmo. Adaptado - Feng (1997)

\begin{tabular}{ccc}
\hline ID & $\begin{array}{c}\text { Duração } \\
(2)\end{array}$ & $\begin{array}{c}\text { Custo } \\
(3)\end{array}$ \\
\hline 1$)$ & 14 & 2.400 \\
1 & 15 & 2.150 \\
1 & 16 & 1.900 \\
1 & 21 & 1.500 \\
1 & 24 & 1.200 \\
2 & 15 & 3.000 \\
2 & 18 & 2.400 \\
2 & 20 & 1.800 \\
2 & 23 & 1.500 \\
2 & 25 & 1.000 \\
3 & 15 & 4.500 \\
3 & 22 & 4.000 \\
3 & 33 & 3.200 \\
4 & 12 & 45.000 \\
4 & 16 & 35.000 \\
4 & 20 & 30.000 \\
5 & 22 & 20.000 \\
5 & 24 & 17.500 \\
5 & 28 & 15.000 \\
5 & 30 & 10.000 \\
6 & 14 & 40.000 \\
6 & 18 & 32.000 \\
6 & 24 & 18.000 \\
7 & 9 & 30.000 \\
7 & 15 & 24.000 \\
7 & 8 & 22.000 \\
\hline
\end{tabular}

Hegazy (1999), por sua vez, faz uma revisão bibliográfica em seu trabalho apontando quais são os tipos de técnica existentes para as análises de trade-off entre custos e prazos. Ele subcategoriza estas análises em três principais tipos: metodologias heurísticas, modelos de programação matemáticos e aplicação de algoritmos genéricos.

São também abordadas explicações de como cada uma das subcategorias funcionam, exemplos de autores que aplicaram cada uma destas subcategorias e os pontos positivos e negativos de cada uma delas. Tais fatores podem ser observados na Figura 2. 


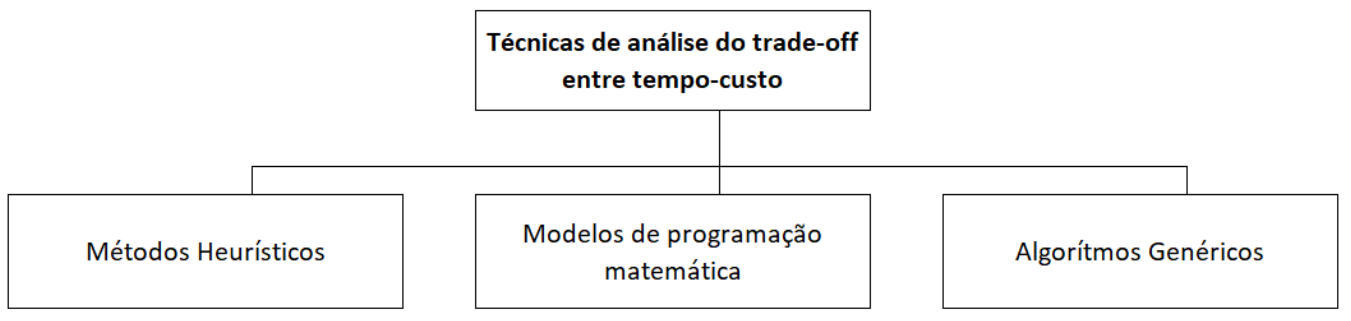

Descrição:

Simples regras práticas

Exemplos:

Siemens 1971

Moselhi 1993

Vantagens:

Fácil de entender

Gera boas soluções

Utilizado para projetos de grande porte

Programação linear, inteira ou dinâmica

Kelly 1961

Liu et. al. 1995

Pode gerar soluções ótimas

\section{Difícil de formular}

Aplica-se a pequenos problemas

Assume em sua maioria relação

linear ao invés de discreta entre

o custo e prazo
Otimização que imitam evolução natural

Feng et. al. 1997

Li and Love 1997

Algorítimo de busca robusto Pode utilizar relações discretas Aplicável para grandes problemas

Consome muito tempo para pesquisas Não consegue dizer quando a solução ótima é atingida

Figura 2 - Subcategorização de análises de trade-off. Adaptado - Hegazy (1999)

Hegazy (1999) também aponta para a curva de relacionamento entre custos e prazos, apontando o ponto de decisão ótimo para determinado projeto. O Gráfico 6 mostra tal relacionamento.

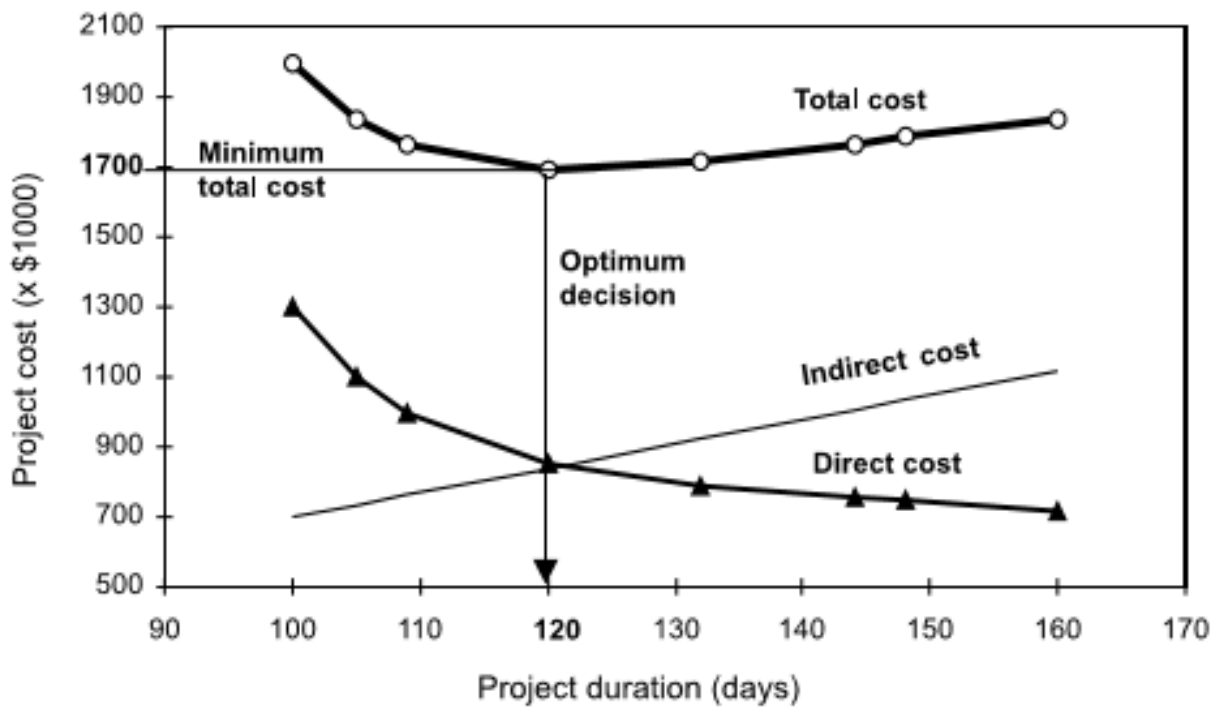

Gráfico 6 - Relacionamento típico entre custos x prazos. Fonte: Hegazy (1999) 
Correlacionando-se o presente trabalho com a abordagem classificativa de Hegazy (1999), pode-se dizer que o método a ser desenvolvido para o cálculo do prazo ótimo se classifica entre os métodos heurísticos e os modelos de programação matemáticos. $\mathrm{O}$ fato de o método proposto se classificar entre os dois modelos citados acima faz com que o método aproveite os pontos fortes dos modelos e elimine alguns dos seus pontos fracos. Como exemplo dos pontos fortes, pode-se citar a facilidade do entendimento, a possibilidade de ser utilizado para grandes projetos e a possibilidade de resultar em boas soluções. E, como exemplo dos pontos fracos eliminados, a falta de rigor matemático e a dificuldade de aplicação e limitação a pequenos projetos.

Chassiakos (2005), por sua vez, faz a análise entre custos e prazos de projetos utilizando métodos de programação linear completa em comparação a uma aproximada.

Mais uma vez, valores para os custos e prazos das atividades são relacionados, entretanto sem entrar no mérito do seu levantamento, uma vez que o principal objetivo do trabalho era a avaliação das aplicabilidades computacionais dos modelos.

O Quadro 8 mostrando o relacionamento entre custos e prazos, e o Gráfico 7 mostrando os resultados obtidos para a aplicação da programação linear exata e aproximada.

Quadro 8 - Valores dos custos x prazos utilizados no algoritmo. Fonte: Chassiakos (2005)

\begin{tabular}{|c|c|c|c|c|c|c|}
\hline \multirow{2}{*}{$\begin{array}{l}\text { Atividade } \\
\text { Número }\end{array}$} & \multicolumn{2}{|c|}{ Normal } & \multicolumn{2}{|c|}{ Alternativa 1} & \multicolumn{2}{|c|}{ Alternativa 2} \\
\hline & Tempo & Custo & Tempo & Custo & Tempo & Custo \\
\hline 1 & 15 & 60 & 12 & 68 & - & - \\
\hline 2 & 25 & 30 & 20 & 38 & 15 & 44 \\
\hline 3 & 25 & 50 & 20 & 54 & 15 & 60 \\
\hline 4 & 12 & 17 & 9 & 21 & - & - \\
\hline 5 & 6 & 3 & - & - & - & - \\
\hline 6 & 12 & 27 & 9 & 32 & - & - \\
\hline 7 & 6 & 8 & - & - & - & - \\
\hline 8 & 20 & 44 & 15 & 48 & 12 & 54 \\
\hline 9 & 12 & 15 & 9 & 22 & - & - \\
\hline 10 & 6 & 3 & - & - & - & - \\
\hline 11 & 1 & 0,5 & - & - & - & - \\
\hline 12 & 25 & 95 & 20 & 105 & 15 & 109 \\
\hline 13 & 15 & 34 & 12 & 41 & 9 & 51 \\
\hline 14 & 12 & 9 & 9 & 13 & - & - \\
\hline 15 & 25 & 30 & 15 & 39 & 12 & 42 \\
\hline 16 & 40 & 79 & 35 & 85 & 30 & 90 \\
\hline 17 & 25 & 23 & 20 & 26 & 12 & 35 \\
\hline 18 & 20 & 14 & 15 & 18 & 12 & 24 \\
\hline 19 & 25 & 14 & 20 & 19 & 15 & 24 \\
\hline 20 & 20 & 39 & 15 & 42 & - & - \\
\hline 21 & 40 & 42 & 35 & 50 & 30 & 58 \\
\hline 22 & 40 & 36 & 30 & 48 & 25 & 56 \\
\hline 23 & 40 & 65 & 35 & 74 & 25 & 79 \\
\hline 24 & 9 & 7 & - & - & - & - \\
\hline 25 & 25 & 45 & 20 & 51 & 15 & 59 \\
\hline 26 & 25 & 50 & 20 & 58 & 15 & 64 \\
\hline 27 & 30 & 60 & 25 & 72 & 20 & 78 \\
\hline 28 & 12 & 9 & 9 & 13 & 7 & 18 \\
\hline 29 & 1 & 0,5 & - & - & - & - \\
\hline
\end{tabular}




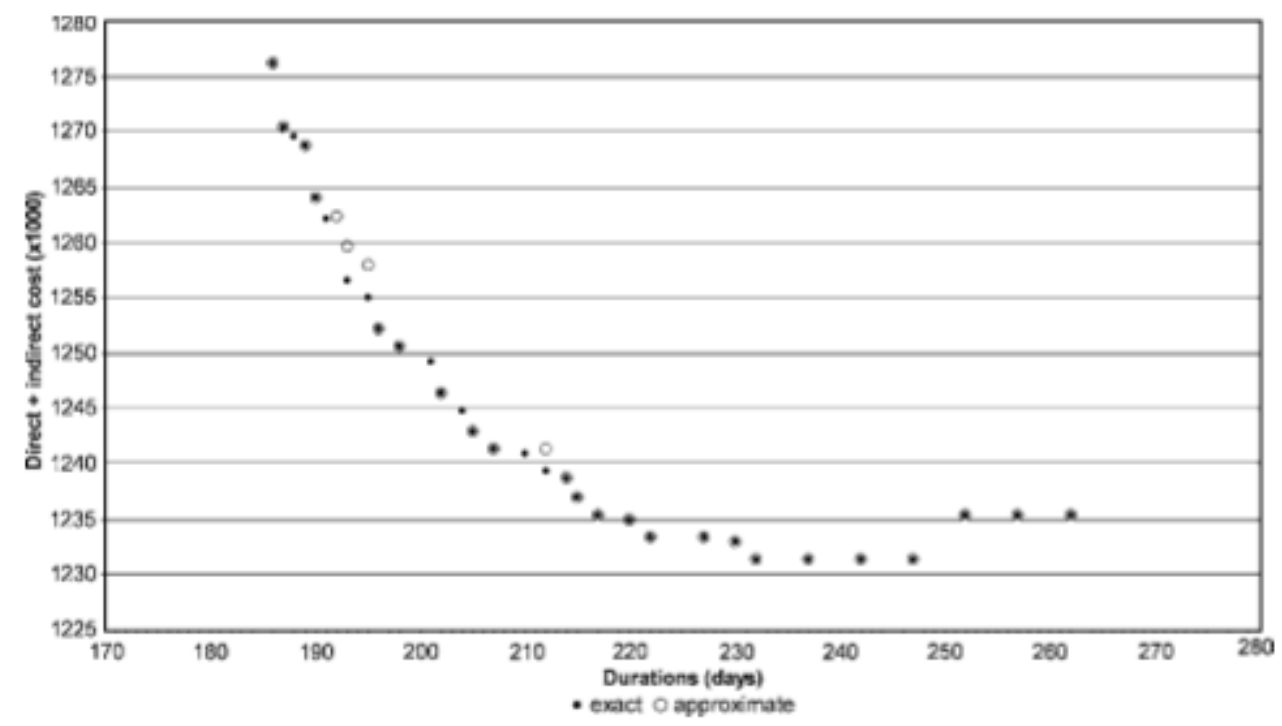

Gráfico 7 - Resultados do algoritmo. Fonte: Chassiakos (2005)

Contador (2010), abordando a solução do problema de balanceamento entre duração e custo de um projeto, cita que os métodos clássicos utilizam a teoria de fluxo em redes para resolver este problema, destacando diversos autores, como Fulkerson (1961), Philips e Dessouky (1977) e Tufekci (1982). Entretanto destaca que todos os métodos desenvolvidos requerem conhecimentos não elementares de pesquisa operacional e guardam pouca relação com a lógica do problema de gerenciamento de projetos.

Todos os trabalhos abordados acima são bastante semelhantes. Indiscutivelmente eles abordam a correlação entre custos e prazos dos projetos e suas características de variabilidade proporcional para os custos indiretos e inversamente proporcional para os diretos. Entretanto todos apresentam limitações na quantidade de atividades do projeto avaliadas e no detalhamento de como as variações de cada um dos custos diretos e indiretos são calculadas.

Outros trabalhos foram verificados, entretanto todo o enfoque de pesquisa que se encontrou para este tema está direcionado para o desenvolvimento de algoritmos, programações e melhorias computacionais ou, então, em abordagens simples e genéricas. Nenhum desenvolvimento de método sistemático e matemático simples, abordando todas as atividades de um projeto de forma detalhada, foi encontrado. 


\section{MÉTODO PROPOSTO}

A proposta está feita em três diferentes etapas:

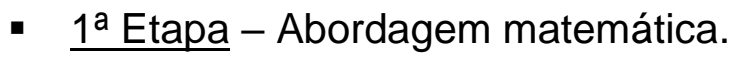

- $2^{\mathrm{a}}$ Etapa - Identificação e isolamento de todos os tipos de custo que podem ter algum aumento ou alguma redução com a variação do prazo do projeto.

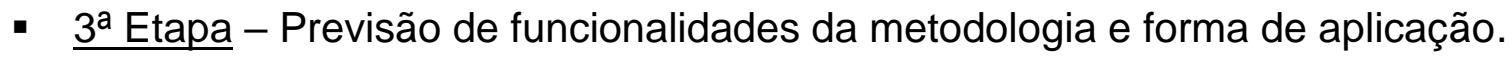

\subsection{MÉTODO PROPOSTO - ABORDAGEM MATEMÁTICA}

Para a determinação do prazo ótimo de um projeto, a tratativa metodológica foi isolar e identificar os fatores de custos do orçamento que variam conforme o prazo do projeto e os que não variam. Prevendo casos em que os custos aumentam proporcionalmente ao aumento do prazo, ou eles se reduzem inversamente ao aumento do prazo.

Em uma análise detalhada, considerando-se os custos diretos e os indiretos com sua relação à variabilidade dos custos no prazo, pode-se observar o Quadro 9 , que indica as premissas e considerações adotadas no desenvolvimento do método deste trabalho.

É importante notar que, para o cálculo do prazo ótimo do projeto em relação aos seus custos, foi feita a consideração de um cenário congelado, ou seja, variações normais de preços devido a reajustamentos, demanda de insumos, variabilidade de impostos, custos de equipamentos, entre outros fatores, não foram consideradas. Adota-se a premissa de que a variabilidade de custos destes itens é coberta por reajustamentos contratuais e que não teriam impacto na análise.

Da mesma maneira, toda a abordagem em relação aos projetos neste trabalho será a mais abrangente, não só no design, mas no gerar ou construir um novo produto. Um outro aspecto importante é que todo o desenvolvimento do método estará sob o ponto de vista das empresas construtoras e dos orçamentistas, e não do cliente; casos em que o ponto de vista mudar serão indicados no trabalho.

Assumiu-se ainda que as variações dos riscos e de contingenciamento, apesar de possuírem característica inversamente proporcional à redução dos prazos, são parâmetros muito complexos de se mensurar e são valores bastante subjetivos para o cálculo. Além disso, os valores de aumento destes itens não representam impactos tão expressivos no cálculo final do prazo ótimo quanto os outros que foram abordados. 
Quadro 9 - Variação dos custos x variação do prazo

\begin{tabular}{|c|c|c|c|}
\hline Item & Subitem & $\begin{array}{c}\text { Variabilidade } \\
\text { no prazo }\end{array}$ & $\begin{array}{l}\text { Característica em } \\
\text { função do prazo }\end{array}$ \\
\hline \multicolumn{4}{|l|}{ Custo Direto } \\
\hline \multirow{3}{*}{ Mão de Obra } & Produtividade & Sim & $\begin{array}{l}\text { Inversamente } \\
\text { proporcial }\end{array}$ \\
\hline & Rotatividade & Sim & $\begin{array}{l}\text { Inversamente } \\
\text { proporcional }\end{array}$ \\
\hline & Encargos Sociais & Sim & $\begin{array}{l}\text { Inversamente } \\
\text { proporcional }\end{array}$ \\
\hline \multirow{4}{*}{ Materiais } & Preço dos insumos & Sim & $\begin{array}{l}\text { Diretamente } \\
\text { proporcial }\end{array}$ \\
\hline & Impostos & $\begin{array}{l}\text { Cenário } \\
\text { congelado }\end{array}$ & Não considerada \\
\hline & Perdas & $\begin{array}{l}\text { Não } \\
\text { considerada }\end{array}$ & Não considerada \\
\hline & Reaproveitamento & $\begin{array}{l}\text { Não } \\
\text { considerada }\end{array}$ & Não considerada \\
\hline \multirow{2}{*}{ Equipamentos } & Custo-horário & $\begin{array}{l}\text { Cenário } \\
\text { congelado }\end{array}$ & Não considerada \\
\hline & Mobilização & Sim & $\begin{array}{l}\text { Inversamente } \\
\text { proporcional }\end{array}$ \\
\hline \multicolumn{4}{|l|}{ Custo Indireto } \\
\hline \multirow{2}{*}{ Mão de Obra } & Efetivo mensal de apoio & Sim & $\begin{array}{l}\text { Diretamente } \\
\text { proporcional }\end{array}$ \\
\hline & EPIs, exames, uniformes & Sim & $\begin{array}{l}\text { Inversamente } \\
\text { proporcional }\end{array}$ \\
\hline \multirow{3}{*}{ Despesas Gerais } & Contas de consumo & Sim & $\begin{array}{l}\text { Inversamente } \\
\text { proporcional }\end{array}$ \\
\hline & Impostos e tributos & $\begin{array}{l}\text { Cenário } \\
\text { congelado }\end{array}$ & Não considerada \\
\hline & Canteiro de obras & Sim & $\begin{array}{l}\text { Inversamente } \\
\text { proporcional }\end{array}$ \\
\hline Imprevistos & Riscos e outros & $\begin{array}{l}\text { Não } \\
\text { considerada }\end{array}$ & Não considerada \\
\hline
\end{tabular}

O Quadro 10 aborda as justificativas e explicações da adoção de cada um dos itens, feitas pela análise de sensibilidade dos fatores através da variação dos prazos. 
Quadro 10 - Variação dos custos x variação do prazo

\begin{tabular}{|c|c|c|}
\hline Item & Subitem & $\begin{array}{l}\text { Por que varia, ou não, com o prazo? } \\
\text { Análise de sensibilidade em função do prazo }\end{array}$ \\
\hline \multicolumn{3}{|l|}{ Custo Direto } \\
\hline \multirow{3}{*}{ Mão de Obra } & Produtividade & $\begin{array}{l}\text { Ao se aumentar muito o efetivo para o desenvolvimento } \\
\text { de uma mesma atividade, a produtividade é reduzida } \\
\text { devido ao aumento da dificuldade de trabalho, à redução } \\
\text { de espaço e possível falta de materiais e recursos }\end{array}$ \\
\hline & Rotatividade & $\begin{array}{l}\text { Ao se aumentar muito o quantitivo de contratação em } \\
\text { um curto espaço de tempo, aumenta-se a chance de } \\
\text { encontrar mão de obra que se adeque menos à obra, ou } \\
\text { que se demita mais facilmente }\end{array}$ \\
\hline & Encargos sociais & $\begin{array}{l}\text { Ao se aumentar muito o efetivo para o desenvolvimento } \\
\text { de uma obra, os encargos sociais calculados de } \\
\text { rescisões saem dos parâmetros médios adotados para } \\
\text { as permanências médias das obras, aumentando assim } \\
\text { muito os custos com indenizações de rescisões e avisos } \\
\text { prévios indenizados }\end{array}$ \\
\hline \multirow{4}{*}{ Materiais } & Preço dos insumos & $\begin{array}{l}\text { Considerando grandes compras em um menor prazo, há } \\
\text { uma redução de custos devido à economia de escala }\end{array}$ \\
\hline & Impostos & $\begin{array}{l}\text { Considerando um cenário congelado para este caso, os } \\
\text { impostos não variam com o prazo do projeto, } \\
\text { permanecendo os mesmos }\end{array}$ \\
\hline & Perdas & As perdas são as mesmas, independentemente do prazo \\
\hline & Reaproveitamento & $\begin{array}{l}\text { Poderia até haver uma redução no reaproveitamento de } \\
\text { materiais no aumento do prazo devido à execução de } \\
\text { inúmeras atividades que estariam sequenciais e } \\
\text { passando a ser executadas simultaneamente devido à } \\
\text { redução de prazo, porém seu efeito é desprezível perto } \\
\text { dos outros fatores }\end{array}$ \\
\hline \multirow{2}{*}{ Equipamentos } & Custo-horário & Considerado um cenário congelado para este caso \\
\hline & Mobilização & $\begin{array}{l}\text { Ao se reduzir o prazo, há uma tendência de aumento da } \\
\text { necessidade de equipamentos, fazendo com que o } \\
\text { número de mobilizações aumente }\end{array}$ \\
\hline \multicolumn{3}{|l|}{ Custo Indireto } \\
\hline \multirow{2}{*}{ Mão de Obra } & $\begin{array}{l}\text { Efetivo mensal de } \\
\text { apoio }\end{array}$ & $\begin{array}{l}\text { Considerando um efetivo fixo de apoio para a obra, o } \\
\text { aumento do prazo faz com que a sua permanência } \\
\text { aumente, gerando assim maiores custos }\end{array}$ \\
\hline & $\begin{array}{l}\text { EPls, exames, } \\
\text { uniformes }\end{array}$ & $\begin{array}{l}\text { Ao se reduzir o prazo da obra, há a necessidade de } \\
\text { maior efetivo, gerando assim uma necessidade maior de } \\
\text { compra de EPls, exames médicos e uniformes }\end{array}$ \\
\hline
\end{tabular}




\begin{tabular}{|l|l|l|}
\hline \multirow{5}{*}{$\begin{array}{l}\text { Despesas } \\
\text { Gerais }\end{array}$} & $\begin{array}{l}\text { Ao se reduzir o prazo da obra, aumenta-se a } \\
\text { Contas de } \\
\text { consumo }\end{array}$ & $\begin{array}{l}\text { necessidade de efetivo, gerando assim maior } \\
\text { necessidade de infraestrutura. Os consumos são } \\
\text { maiores; energia e água, por exemplo, possuem } \\
\text { aumentos significativos de custos quando os consumos } \\
\text { aumentam expressivamente }\end{array}$ \\
\cline { 2 - 4 } & Impostos e tributos \\
\cline { 2 - 4 } & Canteiro de obras & $\begin{array}{l}\text { Considerando um cenário congelado para este caso, os } \\
\text { impostos não variam com o prazo do projeto, } \\
\text { permanecendo os mesmos. Este caso considera os } \\
\text { impostos federais, estaduais e municipais obrigatórios à } \\
\text { empresa construtora }\end{array}$ \\
\hline Imprevistos & $\begin{array}{l}\text { Ao se reduzir o prazo da obra, aumenta-se a } \\
\text { necessidade de efetivo, gerando assim maior } \\
\text { necessidade de infraestrutura }\end{array}$ \\
\hline
\end{tabular}

Para melhor ilustrar o desenvolvimento matemático do método, faz-se uma análise prática utilizando a composição do Quadro 5 e as quantidades de serviço estimadas no Quadro 6, gerando-se o Quadro 11, no qual é possível observar a variabilidade de materiais, equipamentos e mão de obra em função do prazo da obra.

Considerando-se que na obra há $8.720 \mathrm{~m}^{3}$ de concreto de 40 Mpa para ser executados, a partir dos coeficientes da composição de serviço, pode-se calcular a quantidade necessária de cada um dos recursos de mão de obra, de equipamentos e de materiais.

Neste caso, iniciando por materiais, imagine que o projeto fosse executado em um mês, neste caso, haveria a necessidade de consumo de $21.800 \mathrm{~m}^{3}$ de cimento $\left(8.720 \mathrm{~m}^{3} \times 2,5 \mathrm{Kg} / \mathrm{m}^{3}\right)$. Vale ressaltar que, para esta composição, o insumo cimento é apenas computado para o uso do bombeamento do concreto.

Caso o projeto fosse executado em cinco meses, a necessidade mensal média seria de $4.360 \mathrm{~m}^{3} /$ mês $\left(21.800 \mathrm{~m}^{3} / 5\right.$ meses $)$. A variabilidade que se pode ter neste aspecto é a economia de escala gerada nas negociações de aquisições dos insumos, que tendem a ter maiores descontos em negociações de escala maior.

Considerando-se um cenário congelado, no qual as condições de variabilidade de inflações, aumento natural dos preços e outros parâmetros, que normalmente são reequilibradas via reajustamentos contratuais, são desprezadas. Não se pode dizer que o valor gasto com o cimento seria o mesmo no caso de o projeto ser feito em um mês ou em cinco meses, pois em uma única compra poderia ser gerada maior economia que em várias compras menores.

Para a mão de obra, caso este projeto fosse executado em um mês, necessitaria um efetivo médio (considerando-se 176 horas trabalhadas em um mês) de 99 serventes $\left(8.720 \mathrm{~m}^{3} \times 2 \mathrm{hh} / \mathrm{m}^{3} / 176 \mathrm{~h}\right), 74$ pedreiros $\left(8.720 \mathrm{~m}^{3} \times 1,50 \mathrm{hh} / \mathrm{m}^{3} / 176 \mathrm{~h}\right)$ e 5 encarregados civis $\left(8.720 \mathrm{~m}^{3} \times 0,10 \mathrm{hh} / \mathrm{m}^{3} / 176 \mathrm{~h}\right)$, totalizando 178 pessoas. 
Caso a obra fosse executada em 5 meses, o efetivo médio mudaria para 20 serventes (99 serventes / 5 meses), 15 pedreiros (74 serventes / 5 meses) e 1 encarregado civil ( 5 serventes / 5 meses), totalizando 36 pessoas. Neste caso, mesmo considerando o cenário financeiro congelado, os custos finais de cada atividade poderiam acabar variando bastante. A envoltória financeira, ou o quantitativo de horas gastas trabalhadas, seria a mesma, similar ao caso do cimento abordado anteriormente, porém a razão desta variabilidade é que cada funcionário contratado exige da obra inúmeras outras variáveis de custos a ser consideradas que possuam variabilidade de acordo com o prazo de permanência, como, por exemplo, dimensionamento do canteiro de obras, custos de EPIs, custos de exames médicos, verbas rescisórias, treinamentos, entre outros. Tais custos não são diretamente dependentes do número de horas trabalhadas, mas, sim, do quantitativo do efetivo que haverá no projeto, daí, então, a possibilidade de variação de custos. A diferença está nos custos decorrentes de se contratar 178 ou 36 pessoas.

Em um orçamento comum, estes custos de canteiros, EPIs, rescisões e outros normalmente são diluídos e calculados com médias praticadas pelo mercado, como, por exemplo, no caso dos encargos sociais, os valores de verbas rescisórias são calculados com uma média de permanência do efetivo de 9 meses. Entretanto, para uma redução de prazo para cinco ou até um mês, os seus valores necessitam de ajustes.

O mesmo caso vale para os custos agregados, que compõem custos de mobilizações, alojamentos, entre outros. Eles também usualmente são calculados como médias que consideram uma permanência muito maior do efetivo.

Em relação aos equipamentos, na composição abordada especificamente, não existe nenhum equipamento vinculado à atividade, mas o mesmo raciocínio acima deveria ser imaginado. Caso na composição estivesse presente a utilização de caminhões betoneiras para o lançamento do concreto, fica claro que, se a obra fosse feita em um mês, muitos mais caminhões seriam necessários do que se ela fosse executada em cinco meses, acarretando, assim, custos de mobilização de equipamentos muito maiores. 
Quadro 11 - Variabilidade $\mathrm{HH}$ x prazo

\begin{tabular}{|c|c|c|c|c|c|}
\hline \multirow{2}{*}{\multicolumn{3}{|c|}{$\begin{array}{l}\text { COMPOSIÇÃO } \\
\begin{array}{l}\text { Concreto estrutural usinado FCK=40 MPA, com } \\
\text { bombeamento }\end{array} \\
\end{array}$}} & \multirow{3}{*}{$\begin{array}{c}\mathrm{M}^{3} \\
8.720 \\
\text { QTDE DE } \\
\text { RECURSOS } \\
\text { TOTAL }\end{array}$} & \multicolumn{2}{|c|}{$\mathbf{H}$} \\
\hline & & & & \multicolumn{2}{|c|}{176} \\
\hline $\begin{array}{l}\text { RECURSOS DA } \\
\text { COMPOSIÇÃOO }\end{array}$ & UNID & COEF. & & $\begin{array}{l}\text { MÉDIA } \\
\text { RECURSOS } \\
1 \text { MÊS }\end{array}$ & $\begin{array}{l}\text { MÉDIA } \\
\text { RECURSOS } \\
5 \text { MESES }\end{array}$ \\
\hline Ferramentas & $\%$ & 3,00 & 261,60 & & \\
\hline \multicolumn{6}{|c|}{ Grupo: $\quad$ A - EQUIPAMENTO } \\
\hline Custo agregado $\mathrm{MO}$ & $\mathrm{H}$ & 3,60 & 31.392 & & \\
\hline Encargos sociais & $\%$ & 125,00 & 10.900 & & \\
\hline Servente & $\mathrm{H}$ & 2,00 & 17.440 & 99 & 20 \\
\hline Pedreiro & $\mathrm{H}$ & 1,50 & 13.080 & 74 & 15 \\
\hline Encarregado civil & $\mathrm{H}$ & 0,10 & 872 & 5 & 1 \\
\hline \multicolumn{6}{|c|}{ Grupo: $\quad$ B - MÃO DE OBRA } \\
\hline Cimento P CP32-IV & $K G$ & 2,50 & 21.800 & 21.800 & 4.360 \\
\hline Taxa de bombeamento & M3 & 1,03 & 8.981 & 8.981 & 1.796 \\
\hline Usinagem de concreto & M3 & 1,03 & 8.981 & 8.981 & 1.796 \\
\hline Material para concreto & M3 & 1,03 & 8.981 & 8.981 & 1.796 \\
\hline E - MATEI & & & & & \\
\hline
\end{tabular}

A partir das exemplificações acima, foi realizada a discretização dos elementos da equação, isolando apenas os itens que podem variar, conforme o Quadro 9 e o Quadro 10 , e que foram descritos neste item. Neste caso específico, são encargos sociais, ferramentas e custos agregados - canteiro, equipamentos de segurança, transporte.

Ao segregar todos os custos variáveis e invariáveis ao prazo da Equação (10), é possível chegar à Equação (12) para o cálculo dos custos totais da obra.

$$
\begin{gathered}
C T_{t}=\left(M O^{\prime}{ }_{o}+M a t^{\prime}{ }_{o}+E q^{\prime}{ }_{o}+C I^{\prime}{ }_{O}\right) \\
+\left(K R S \frac{M^{\prime}{ }_{t}}{t} S_{m}(A)+M^{\prime}{ }_{t} S_{m} \frac{(B+H)}{t}+\frac{E q_{t}^{\prime}}{t}(C)\right. \\
\left.+K R S \frac{M^{\prime}{ }_{t}}{t}(D+E+F)-M a t^{\prime}{ }_{0} \frac{(G)}{t}+C I^{\prime}{ }_{t} \times t\right)
\end{gathered}
$$


Onde:

$M O^{\prime}{ }_{o}$ - Custos totais de MO Direta sem considerar aspectos variáveis no prazo

Mat $^{\prime}{ }_{0}$ - Custos totais de Mat. Diretos sem considerar aspectos variáveis no prazo

$E q^{\prime}{ }_{o}-$ Custos totais de Equip. Diretos sem considerar aspectos variáveis no prazo

$S_{m}$ - Custo médio ponderado dos salários de todo o efetivo direto

A Equação (12) não se diferencia em nada da Equação (10), apenas foram isolados os itens que podem ter variação de custos conforme o prazo do projeto é modificado.

A parte 1 da Equação (12) são todos os itens de orçamento (mão de obra, materiais, equipamentos e custos iniciais de mobilização da obra) que não têm variação conforme o prazo. Já a parte 2 é composta por todos os custos que variam conforme o prazo. A seguir, o descritivo de cada um dos itens.

O primeiro item M't refere-se ao total de mão de obra orçada para a execução do projeto em um mês. A partir deste quantitativo, é possível dimensionar os impactos que o aumento ou a redução de prazo pode causar na mão de obra, isto porque, quando dividimos o M't pelo t (prazo da obra), obtemos o efetivo médio da obra.

$$
M^{\prime}{ }_{t}=\frac{\sum_{i=1}^{n} \operatorname{CompMO}_{i} \times Q t d e_{i}}{h h M O_{m e ̂ s}}
$$

O item Eq't refere-se ao total de equipamentos orçados para a execução do projeto em um mês. Da mesma maneira, a partir deste quantitativo em mãos, é possível dimensionar os impactos que o aumento ou a redução de prazo pode causar nos quantitativos de equipamentos, isto porque, quando divide-se o Eq't pelo $t$ (prazo da obra), obtém-se o quantitativo médio de equipamentos da obra.

$$
E q_{t}^{\prime}=\frac{\sum_{i=1}^{n}{\operatorname{Comp} E q_{i} \times Q t d e_{i}}_{h h E q_{m e ̂ s}}}{h{ }^{\prime}}
$$

O item Cl't refere-se ao custo indireto do efetivo adicionado aos gastos gerenciais mensais. A partir deste valor, multiplicando-se pelo prazo da obra em meses, podese obter o custo indireto.

$$
C I^{\prime}{ }_{t}=C I_{\text {mensal }}
$$

No Quadro 12, seguem descritos os indicadores restantes: 
Quadro 12 - Indicadores da Equação de Prazo Ótimo

\begin{tabular}{|l|l|}
\hline Item & Descrição \\
\hline A & Custo de Rescisões \\
\hline B & Perda de Produtividade (aumento efetivo) \\
\hline C & Custo Mobilização Equipamentos \\
\hline D & Custo Canteiro de Obras \\
\hline E & Custos QSMS, treinamentos \\
\hline F & Custos EPI + exames médicos \\
\hline G & Economia de Escala - Suprimentos \\
\hline R & Índice de Rotatividade de MO \\
\hline S & Percentual de MO não subcontratada \\
\hline K & Fator majorador de pico \\
\hline H & Aumento de custos de horas extras \\
\hline
\end{tabular}

A partir da obtenção de todos os indicadores, para haver uma tratativa mais fácil do método, despreza-se a parte independente do prazo da Equação (12). Isto pode ser feito porque os custos provenientes dela permanecerão os mesmos, independentemente da variação do prazo do projeto. Além disso, a metodologia proposta pretende apenas analisar os impactos decorrentes da variação dos prazos.

Desta forma, segue a Equação (16), que indica quais os custos variáveis da obra e contendo apenas os indicadores que possuem variabilidade com o prazo.

$$
\begin{aligned}
C T A_{t}=(K R S & \frac{M^{\prime}{ }_{t}}{t} S_{m}(A)+M^{\prime}{ }_{t} S_{m} \frac{(B+H)}{t}+\frac{E q^{\prime}{ }_{t}}{t}(C) \\
& \left.+K R S \frac{M^{\prime}{ }_{t}}{t}(D+E+F)-M a t^{\prime}{ }_{0} \frac{(G)}{t}\right)+\left(C I^{\prime}{ }_{t} \times t\right)
\end{aligned}
$$

Neste caso, a parte 1 da Equação (16) representa os custos diretos variáveis com o tempo, e a parte 2 representa os custos indiretos.

A partir da Equação (16), fica fácil observar os fatores que variam diretamente proporcionais ao prazo e os que variam inversamente proporcionais ao prazo. Podese descobrir também a partir dela o ponto $t$ onde o custo total do projeto será mínimo, para isto, deriva-se a equação em função do prazo t e iguala-se a zero, conforme a Equação (17). 


$$
\begin{aligned}
\frac{\partial C T A_{t}}{\partial t}=(- & K R S \frac{M^{\prime}{ }_{t}}{t^{2}} S_{m}(A)-M^{\prime}{ }_{t} S_{m} \frac{(B+H)}{t^{2}}-\frac{E q^{\prime}{ }_{t}}{t^{2}}(C) \\
- & \left.K R S \frac{M^{\prime}{ }_{t}}{t^{2}}(D+E+F)+M a t^{\prime}{ }_{0} \frac{(G)}{t^{2}}+C I^{\prime}{ }_{t}\right)=0
\end{aligned}
$$

Ao se fazer a segunda derivada da Equação (17) e fazer a análise de declividade da curva, pode-se comprovar que o ponto obtido ao se igualar a zero a Equação (17) é um ponto de mínimo da curva. Desta forma, ao se manipular os termos, é possível chegar à Equação (18), que representa o prazo ótimo teórico do projeto.

$$
t_{\text {ótimo }}=\sqrt{\frac{K R S M^{\prime}{ }_{t}\left(A S_{m}+D+E+F\right)+M^{\prime}{ }_{t} S_{m}(B+H)+E q^{\prime}{ }_{t}(C)-M a t^{\prime}{ }_{0}(G)}{C I^{\prime}{ }_{t}}}
$$

Ressalta-se que a Equação (18) não é limitada apenas aos indicadores $A, B, C, D$, $\mathrm{E}, \mathrm{F}, \mathrm{G}$ e $\mathrm{H}$, podendo o orçamentista, durante o uso deste método, adequar o equacionamento incluindo quaisquer $n$ fatores que se ache pertinentes ao projeto.

Para o cálculo da redução de custo entre um prazo t e o prazo t-ótimo, segue a Equação (19):

$$
\begin{aligned}
\Delta C A_{t_{\text {ótimo }}}=( & K R S \frac{M^{\prime}{ }_{t}}{t} S_{m}(A)+M^{\prime}{ }_{t} S_{m} \frac{(B+H)}{t}+\frac{E q^{\prime}{ }_{t}}{t}(C) \\
& \left.+K R S \frac{M^{\prime}{ }_{t}}{t}(D+E+F)-M a t^{\prime}{ }_{0} \frac{(G)}{t}+C I^{\prime}{ }_{t} \times t\right) \\
& -\left(K R S \frac{M^{\prime}{ }_{t}}{t_{\text {ótimo }}} S_{m}(A)+M^{\prime}{ }_{t} S_{m} \frac{(B+H)}{t_{\text {ótimo }}}+\frac{E q^{\prime}{ }_{t}}{t_{\text {ótimo }}}(C)\right. \\
& \left.+K R S \frac{M^{\prime}{ }_{t}}{t_{\text {ótimo }}}(D+E+F)-M^{\prime} t^{\prime}{ }_{0} \frac{(G)}{t_{\text {ótimo }}}+C I^{\prime}{ }_{t} \times t_{\text {ótimo }}\right)
\end{aligned}
$$

No Gráfico 8 e no Gráfico 9, mostra-se como a curva da determinação do prazo ótimo seria representada nos projetos, considera-se o eixo x como representante do tempo e o eixo y como representante dos custos. 


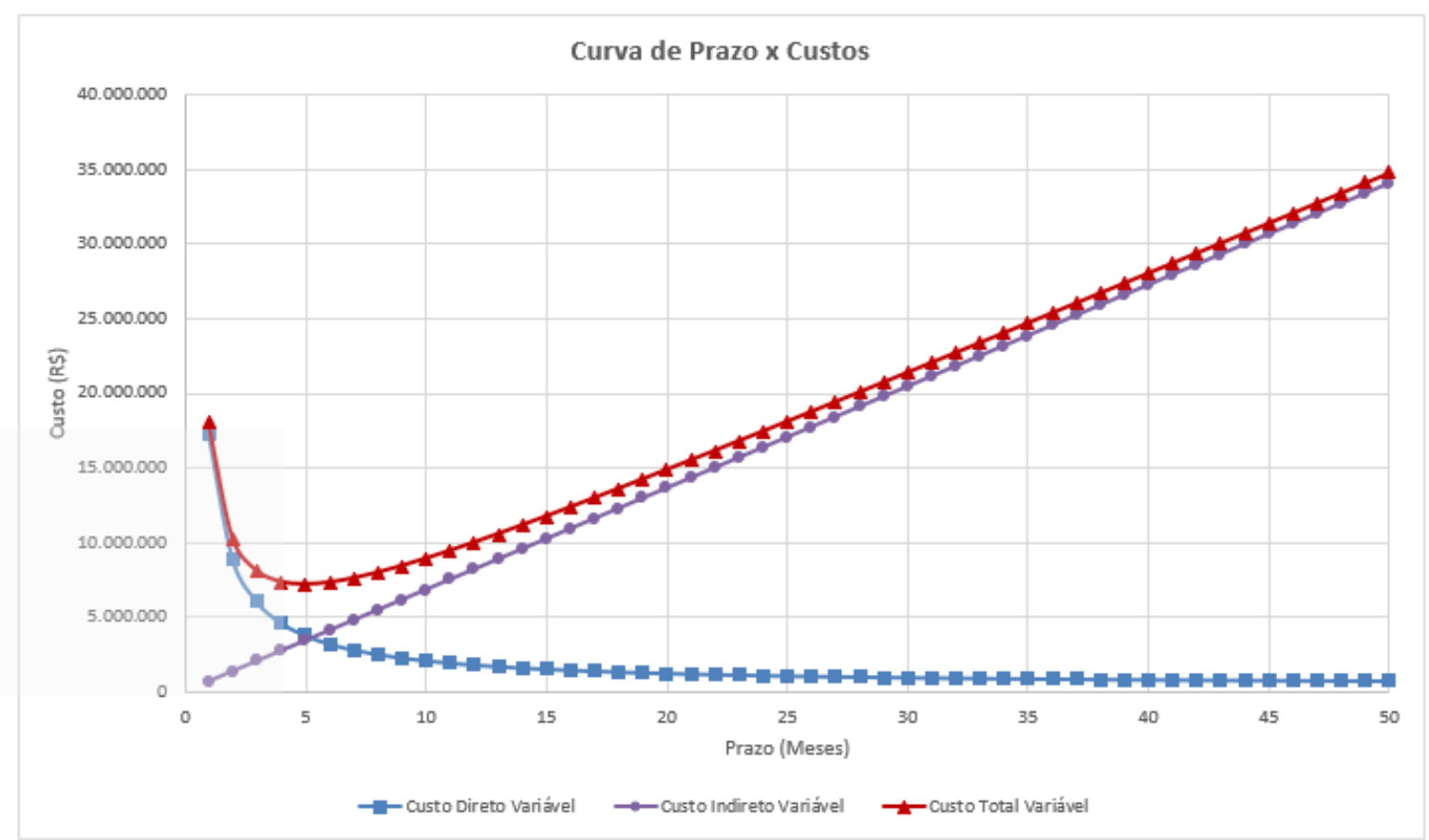

Gráfico 8 - Curva de determinação de prazo ótimo (apenas custos variáveis)

Pode-se notar no Gráfico 8 que os custos indiretos possuem uma curva bem definida representada por uma reta, já os custos diretos possuem uma curva decrescente em formato de uma hipérbole. A soma dos custos indiretos com os diretos forma uma curva que se aproxima de uma parábola, possuindo um ponto de mínimo.

O Gráfico 9, em sua parte superior, representa o custo total do projeto considerandose a somatória dos custos variáveis ao tempo representado na parte inferior com os custos não variáveis. 


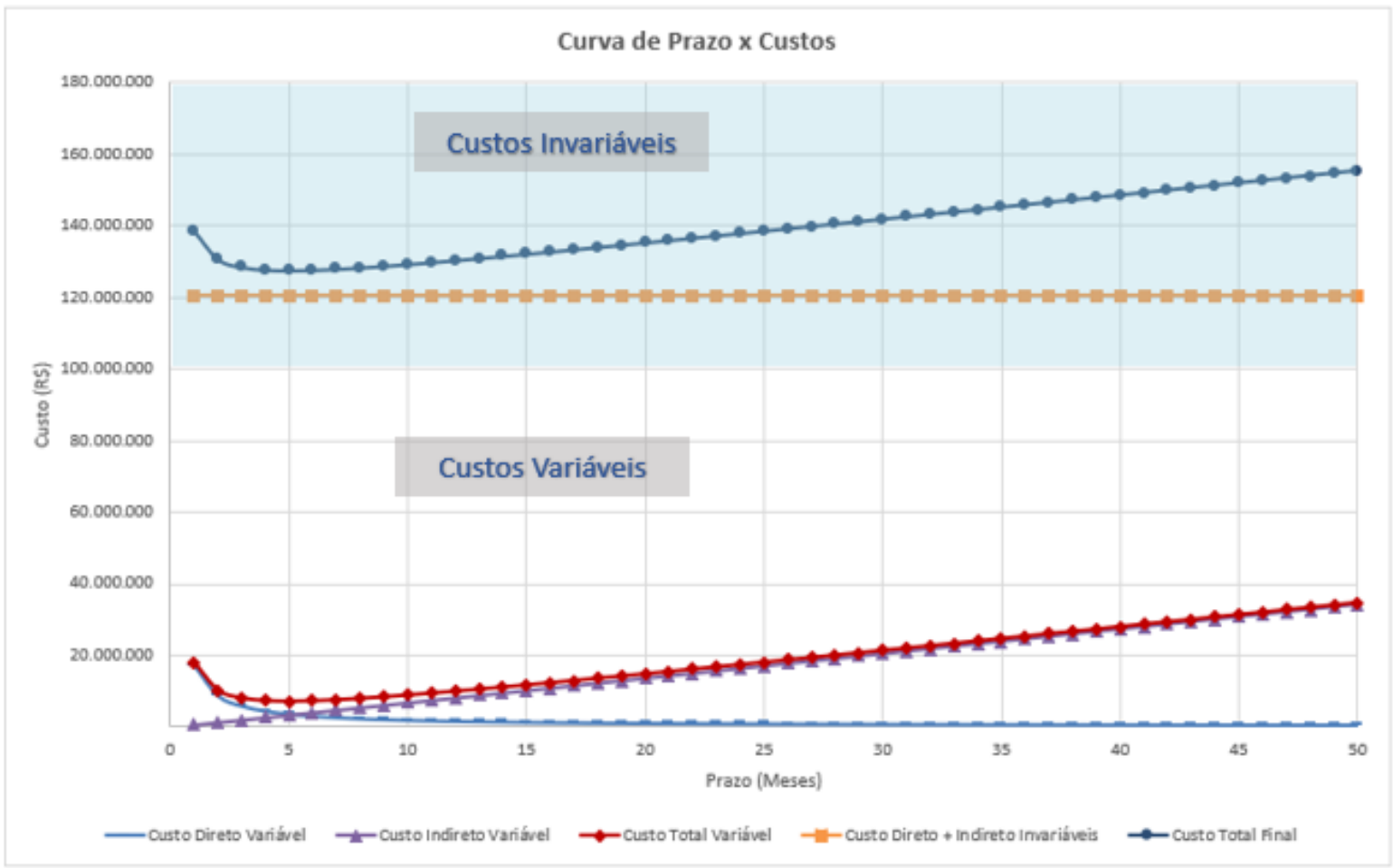

Gráfico 9 - Curva de determinação de prazo ótimo (custos variáveis e invariáveis)

\subsubsection{ABORDAGEM MATEMÁTICA - GENERALIZAÇÕES}

A partir da determinação de todo equacionamento matemático para o cálculo da curva dos custos variáveis da obra em função do tempo e do prazo ótimo, pode-se utilizar o conhecimento de tais fórmulas e gráficos resultantes para possíveis generalizações matemáticas em diferentes particularidades de obras.

\subsubsection{CASO 1 - PRAZO ESTIMADO MAIOR QUE PRAZO ÓTIMO}

O primeiro caso a ser abordado é o da curva dos custos variáveis dada pela Equação (16). Neste caso, a partir da determinação das 16 variáveis desta equação, a curva dos custos variáveis pode ser traçada. O conhecimento desta curva para a obra que o orçamentista está estudando é de extrema importância, pois a partir dela ele consegue visualizar o potencial de redução de custos do projeto a partir da variação do prazo.

Não são todos os projetos que possuem ampla margem de variação dos custos em função do tempo. Neste caso, o orçamentista, detendo esta informação, pode adequar o cronograma da obra da maneira que seja mais factível para a empresa, pois os custos não variam muito com a variação dos prazos.

Em um caso oposto, caso a curva indique ampla variação dos custos em relação ao prazo, o orçamentista deve se atentar a esta particularidade e tentar conceber 0 
cronograma da obra visando ao máximo a redução dos prazos ou ao máximo a aproximação do prazo a ser adotado no orçamento ao prazo ótimo determinado.

Imagine que o orçamentista inicialmente tinha concebido em seu planejamento a duração da obra de 30 meses, que, ao calcular o prazo ótimo pela Equação (18), encontre um prazo ótimo de apenas 3 meses e que, ao traçar a curva da obra, se depare com um gráfico conforme o Gráfico 10.

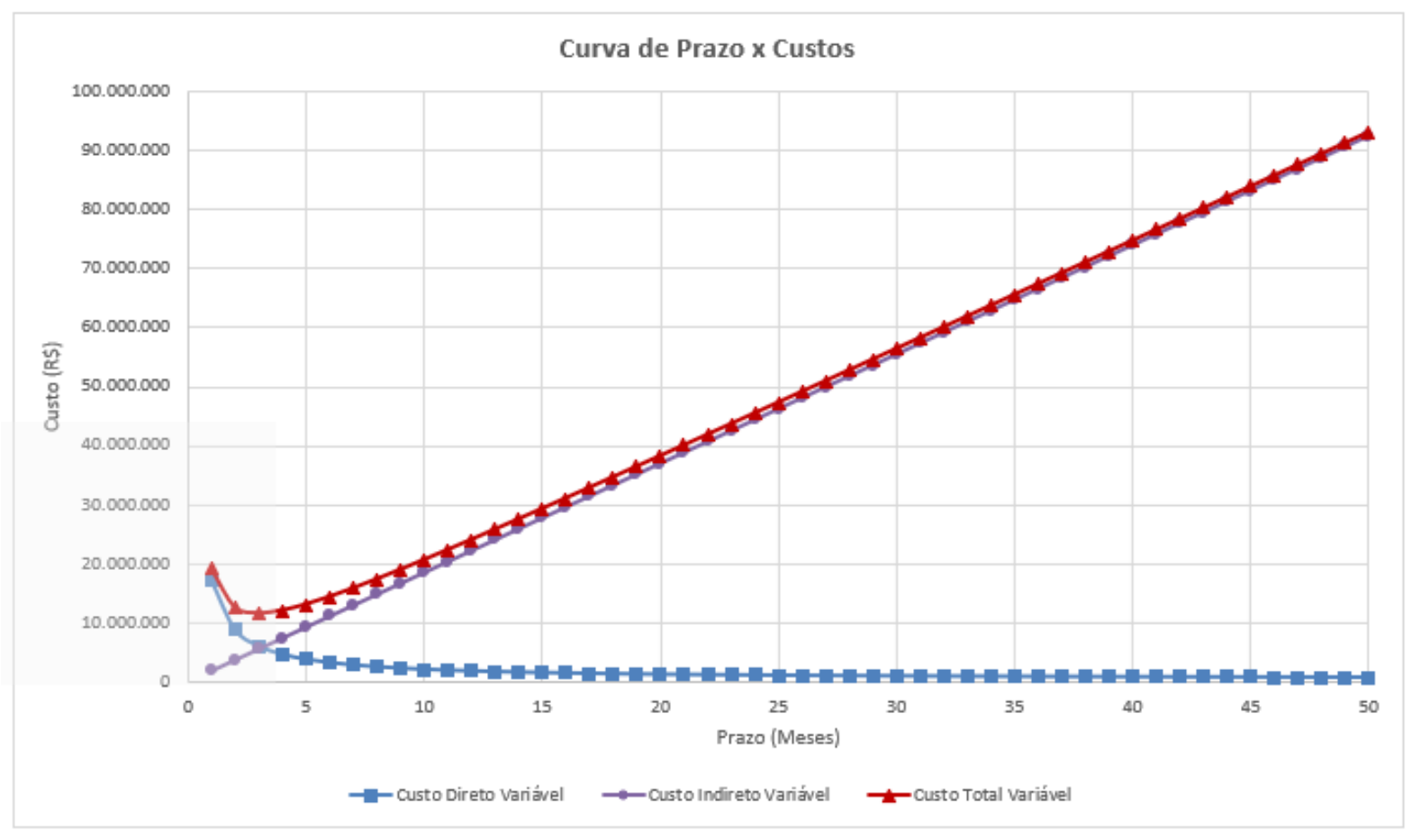

Gráfico 10 - Curva de determinação de prazo ótimo (apenas custos variáveis)

Durante o cálculo do prazo ótimo, o prazo resultante da Equação (18), que, por ser estritamente matemático, muitas vezes se mostra inviável e inexequível para 0 empreendimento, imagine a redução de um empreendimento originalmente concebido para 30 meses para apenas 3 meses.

Porém o conhecimento do prazo ótimo, e o quão longe o prazo concebido inicialmente para a obra estava dele, e o comportamento da curva de custos variáveis da obra são de fundamental importância, pois permitem ao orçamentista saber qual o potencial de economia que a obra pode ter com a variação dos prazos.

No Gráfico 10, a curva de custos totais variáveis se mostra muito íngreme, o que indica que qualquer tratativa para redução de prazos que o orçamentista execute pode gerar economia financeira considerável. Sendo assim, o orçamentista deve ao máximo tentar reduzir o prazo do projeto, tendendo ao prazo ótimo. A redução máxima de prazo que o orçamentista pode conceber é a máxima viável ou exequível para as características da obra e das tecnologias existentes.

Como exemplo deste caso, a redução do prazo do projeto de 30 meses para 20 meses poderia gerar uma economia para a empresa de aproximadamente $R \$ 20$ MM. 
Agora, considerando-se outro caso com um tipo diferente de comportamento da curva, imagine que o orçamentista inicialmente tinha concebido em seu planejamento a duração da obra para os mesmos 30 meses, que, ao calcular o prazo ótimo pela Equação (18), encontre um prazo ótimo de 18 meses e que, ao traçar a curva da obra, se depare com um gráfico conforme o Gráfico 11.

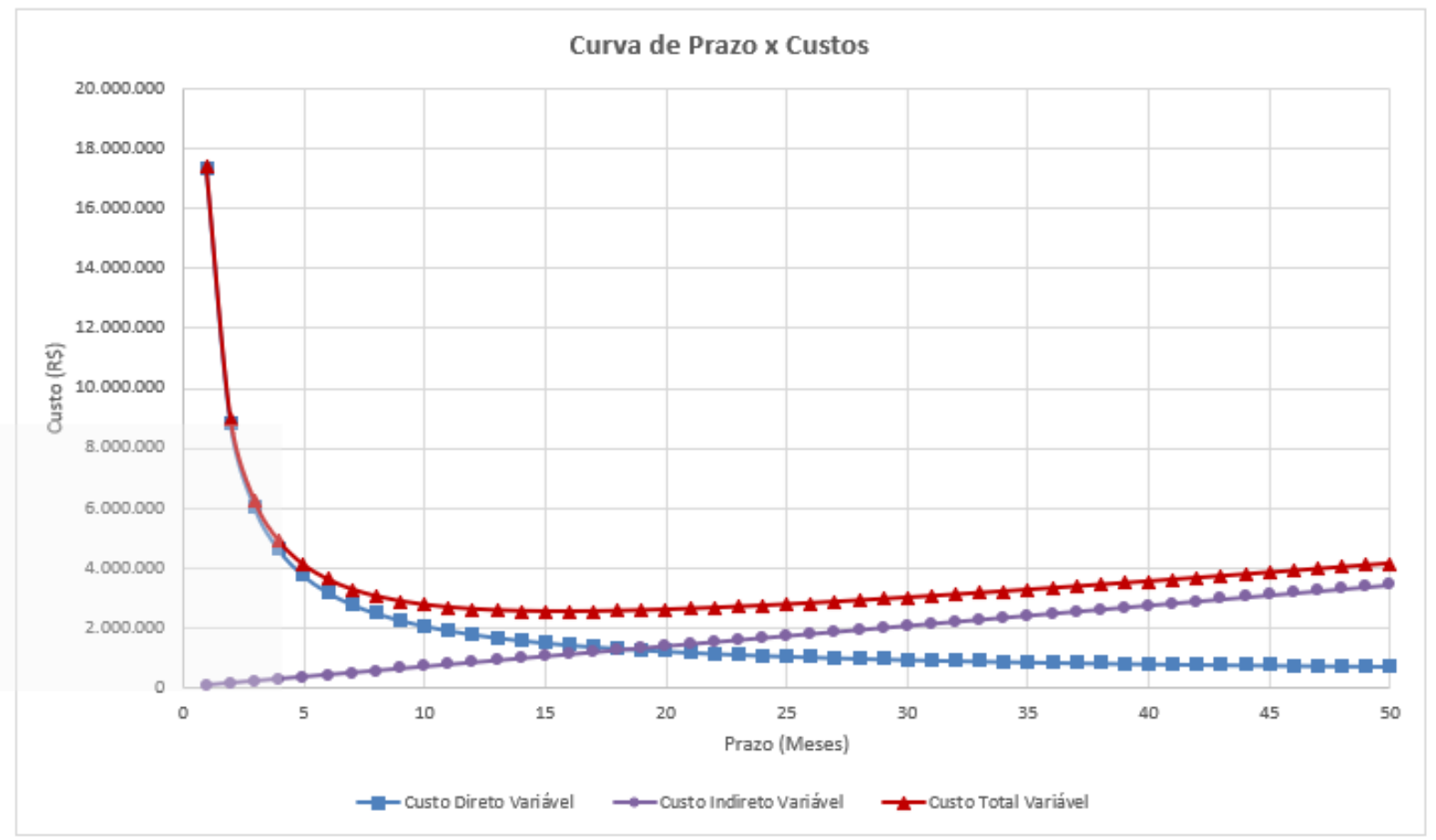

Gráfico 11 - Curva de determinação de prazo ótimo (apenas custos variáveis)

Neste caso do Gráfico 11, a curva vermelha de custos variáveis não se mostra muito íngreme para os prazos maiores que o prazo ótimo, o que indica que qualquer tratativa para a redução de prazos que o orçamentista execute não deve gerar economia financeira considerável. Sendo assim, o orçamentista pode adequar o seu cronograma às outras necessidades da empresa.

Como exemplo deste caso, a redução do prazo do projeto de 30 meses para 20 meses poderia gerar uma economia para a empresa que talvez não fosse tão significativa quando analisados todos os valores da obra, que, neste caso, se aproximaria de $\mathrm{R} \$ 500$ mil.

Os dois casos acima descritos são casos que se enquadram no caso de o prazo originalmente estimado para o empreendimento ser maior que o prazo ótimo calculado, que são casos mais comuns, vendo que a formulação deste cálculo é totalmente matemática e pode apresentar prazos inviáveis ou até mesmo inexequíveis. 


\subsubsection{CASO 2 - PRAZO ESTIMADO MENOR QUE PRAZO ÓTIMO}

Quando o prazo do empreendimento originalmente adotado é menor que o prazo ótimo, fato que pode ocorrer em situações mais raras, cuidados adicionais devem ser tomados, pois a curva neste ponto sempre apresenta variações muito mais agudas. Isto deve-se justamente pelo tipo matemático da curva ser hiperbólico, e, neste caso, o orçamentista deve aumentar o prazo da obra para o prazo ótimo calculado caso o objetivo seja a redução de custos.

\subsubsection{DETERMINAÇÃO DAS ZONAS DE PROJETO NAS CURVAS DE CUSTO}

Outro aspecto extremamente importante nas determinações do prazo ótimo teórico e da curva dos custos variáveis é que através deles é possível determinar zonas características de obras para as variações de prazo. Este procedimento é válido para todos os casos abordados anteriormente.

A partir do Gráfico 12, são perceptíveis os custos para o prazo inicialmente concebido para o projeto - 30 meses, para o prazo adotado - 20 meses e para o prazo ótimo - 3 meses. A partir destes pontos, pode-se determinar duas zonas no gráfico extremamente importantes - zona de prazos com possibilidades de mudança, caracterizada pela área em azul e onde o cronograma do projeto tem reais possibilidades de mudanças. Outra área importante é e zona de limitação tecnológica caracterizada pela área em vermelho no gráfico. Em tal zona, apesar de, com a redução dos prazos, ser possível realizar uma altíssima economia financeira, o agente crítico aqui são as limitações tecnológicas existentes no setor da construção, e é quando o projeto atinge o crash time, conforme abordado em todo o Item 2.3.

Cabe ao orçamentista, quando se encontra na zona de limitação tecnológica, verificar que caso a possibilidade de redução de custos nesta área seja muito grande, possíveis análises de mudanças tecnológicas podem ser adotadas, mesmo que a mudança da tecnologia seja mais cara, a economia no final pela redução de prazo pode ser ainda maior. 


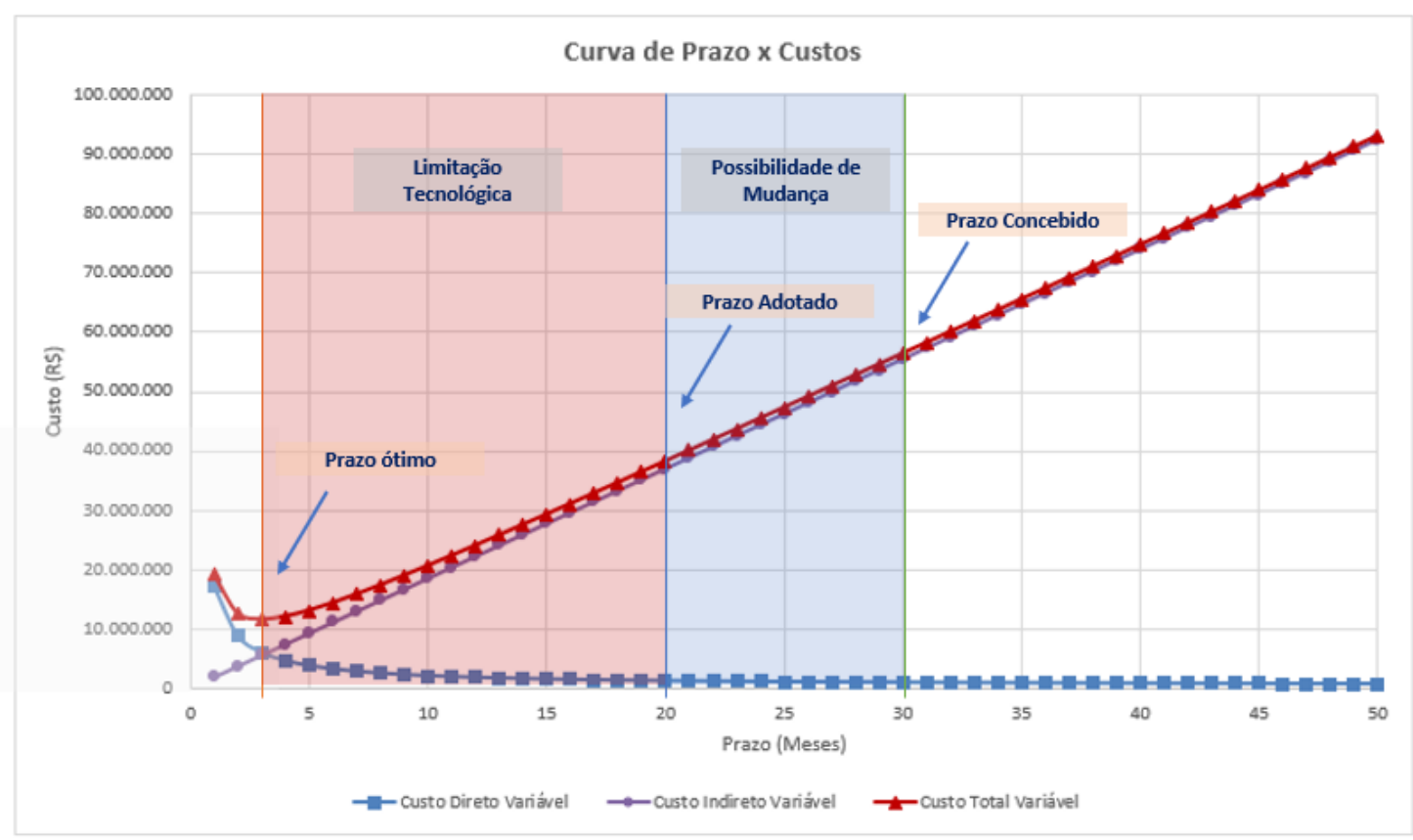

Gráfico 12 - Curva de determinação de prazo ótimo (apenas custos variáveis) - Zonas dos projetos

\subsubsection{ABORDAGEM FINANCEIRA - RECEITAS E REMUNERAÇÃO}

Não há dúvidas de que a modelagem financeira de um projeto é extremamente importante para o cálculo de indicadores de qualidade de investimento e retorno financeiro, como, por exemplo, TIR - Taxa Interna de Retorno, FCD - Fluxo de Caixa Descontado, rentabilidade, VLP - Valor Presente Líquido, entre outros. Entretanto o presente trabalho não tem um enfoque direto nestas áreas e, sim, nos aspectos isolados dos custos das obras, conforme abordado anteriormente.

A particularidade das receitas das obras, com suas inúmeras variações, faz com que a extrapolação matemática do método de cálculo do prazo ótimo, levando em conta as receitas, fique extremamente complexa. A análise passaria de pontual para uma análise detalhada de cada período de fluxo financeiro da obra, perdendo, desta forma, o intuito geral do desenvolvimento pretendido.

Ressalta-se, entretanto, que os custos e as receitas das obras são fortemente correlacionados. Desta forma, a metodologia desenvolvida possibilita aos orçamentistas e às empresas obter um ponto de partida da região de menores custos para a modelagem e estruturação financeira da obra, facilitando e reduzindo muito o trabalho.

Abaixo, segue uma descrição de como a abordagem incluindo as receitas pode ser feita, entretanto não é dado um detalhamento muito grande, uma vez que este não é o intuito do trabalho. 


\subsubsection{DESEMBOLSO FINANCEIRO}

Em relação aos custos, a metodologia adota a premissa de invariabilidade ou "congelamento" do cenário no que tange a desvalorização dos insumos e serviços por inflação ou aumento dos preços, uma vez que na grande parte das obras existentes há instrumentos contratuais entre contratante e contratado que possibilitam tais correções.

Sob o aspecto do custo do capital investido, em relação aos desembolsos financeiros e à remuneração do capital, quando consideram-se as taxas de juros, existem dois possíveis cenários.

Um deles é a análise do ponto de vista do proprietário ou investidor, em que certamente a redução dos prazos culmina em aumento dos desembolsos. Mesmo que haja a redução dos custos, dependendo das taxas de juros existentes no local da obra, os ganhos na economia dos custos devido à redução de prazo podem não ultrapassar as possíveis perdas de investimento de capital. Para este caso, sugerese que seja feita a seguinte análise:

$$
\begin{aligned}
\Delta F_{t_{\mathrm{o}} \text { timo }}= & \left(\frac{F_{1}}{(1+i)^{1}}+\frac{F_{2}}{(1+i)^{2}}+\cdots+\frac{F_{t}}{(1+i)^{t}}\right) \\
& -\left(\frac{F_{1}}{(1+i)^{1}}+\frac{F_{2}}{(1+i)^{2}}+\cdots+\frac{F_{t}}{(1+i)^{t_{\text {ótimo }}}}\right)
\end{aligned}
$$

Onde:

$\Delta F_{t_{\text {ótimo }}}-$ Variação dos ganhos financeiros, considerando os fluxos de caixa

$F_{n}-$ Fluxo financeiro no mês $n$

$t$ - Prazo do projeto (maior que o prazo ótimo)

$i$ - Taxa de juros ou de remuneração financeira

$t_{\text {ótimo }}$ - prazo ótimo do projeto calculado pelo método

$$
\text { Análise de Fluxos }=\Delta F_{t_{\text {ótimo }}}-\Delta C A_{t_{\text {ótimo }}}
$$

Onde:

$\Delta C A_{t_{\text {ótimo }}}-$ Redução de custos da redução do prazo t para o prazo $t$ - ótimo

O resultado da Equação (21) contabiliza os ganhos de custos devido à mudança de um projeto do prazo t para o prazo t-ótimo menos os ganhos ou perdas de capital que possam ocorrer devido ao aspecto da variação dos desembolsos. Caso o resultado seja maior que zero, a adoção do prazo ótimo deve fazer sentido ao 
investidor, caso contrário, não faria sentido. Entretanto é prematuro afirmar que não faria sentido, pois existem inúmeros projetos nos quais mesmo que a entrega prematura seja mais custosa, os possíveis ganhos decorrentes desta entrega podem extrapolar as perdas. Um exemplo pode ser o caso de uma fábrica, imagine que ao final do cálculo da análise de fluxo, a redução do projeto em 3 meses para o prazo ótimo gere uma perda de $R \$ 1 \mathrm{MM}$, se a cada mês a fábrica pode gerar um lucro de $\mathrm{R} \$ 4 \mathrm{MM}$, tal redução faz sentido, mesmo que na análise de fluxos se chegue a um valor negativo.

Um segundo caso de análise é sob o ponto de vista do executor, neste caso, a mesma formulação das Equações (20) e (21) deve ser utilizada, porém, de maneira geral, na grande maioria dos contratos existentes, o executor vai tendo fluxos financeiros de receita de acordo com os avanços, sendo assim, os custos de desembolsos financeiros são muito inferiores quando comparados ao primeiro caso, pois, a cada desembolso periódico do executor, há uma contrapartida de receita. Desta forma, de maneira bem mais simplista, pode-se até mesmo considerar que as variações de ganhos financeiros são insignificantes ao se compará-las com os outros valores.

Quando as variações de ganho ficam insignificantes, a análise de fluxo tende a se limitar a apenas à análise inicial do trabalho - apenas aos custos.

\subsubsection{PROCEDIMENTOS E ETAPAS DE APLICAÇÃO DA METODOLOGIA}

Para a aplicação do método, o orçamentista deve estruturar o estudo em algumas etapas fundamentais que são descritas a seguir.

\section{$1^{\text {a }}$ Etapa - Caracterização do objeto}

Nesta primeira etapa, o orçamentista deve fazer uso dos recursos disponibilizados no edital da obra, caso exista, nos requisitos solicitados pelo cliente e em toda a documentação-base disponível.

É importante que o orçamentista identifique parâmetros de custo-base do projeto, prazo original requisitado, quantidades e composições de projeto, projetos básicos e executivos, além de todos os parâmetros já detalhados no Item 2.1.2.

A identificação destes parâmetros é importante, pois eles formarão uma linha-base para servir de comparação com os futuros custos e prazos a ser determinados, além de fornecer os dados necessários para que as curvas de variabilidade entre os custos e prazos possam ser traçadas.

\section{2를 Etapa - Parâmetros de referência da equação dos custos variáveis}

No cálculo das variáveis das equações de variabilidade dos custos e prazos, o orçamentista deve determinar 16 parâmetros fundamentais para a concepção da curva de variabilidade dos custos e do prazo ótimo teórico, conforme as Equações (16) e (18). O Quadro 13 mostra as variáveis e como elas devem ser identificadas. 
Quadro 13 - Identificação dos Indicadores da Equação de Prazo Ótimo

\begin{tabular}{|c|c|c|c|}
\hline Item & Descrição & Determinação & Resultado Exemplo \\
\hline$M^{\prime} t$ & $\begin{array}{l}\text { Quantitativo total de mão de } \\
\text { obra orçada para a execução } \\
\text { do projeto em um mês }\end{array}$ & $\begin{array}{l}\text { A determinação deste fator } \\
\text { envolve a multiplicação de todos } \\
\text { os quantitativos de serviços da } \\
\text { obra levantados multiplicados } \\
\text { por suas respectivas } \\
\text { composições para mão de obra }\end{array}$ & $\begin{array}{l}3.540 \text { funcionários, sendo } \\
\text { s } 1.500 \text { pedreiros, } 1.000 \\
\text { carpinteiros, } 1.000 \\
\text { serventes, } 40 \\
\text { encarregados }\end{array}$ \\
\hline Eq't & $\begin{array}{l}\text { Quantitativo total de } \\
\text { equipamentos orçados para a } \\
\text { execução do projeto em um } \\
\text { mês }\end{array}$ & $\begin{array}{l}\text { A determinação deste fator } \\
\text { envolve a multiplicação de todos } \\
\text { os quantitativos de serviços da } \\
\text { obra levantados multiplicados } \\
\text { por suas respectivas } \\
\text { composições para } \\
\text { equipamentos }\end{array}$ & $\begin{array}{l}453 \text { equipamentos, sendo } \\
\text { s } 150 \text { escavadeiras, } 100 \\
\text { caminhões caçamba, } 100 \\
\text { pás carregadeira, } 100 \\
\text { retroescavadeiras, } 3 \\
\text { caminhões pipa }\end{array}$ \\
\hline Cl't & $\begin{array}{l}\text { Custo indireto do efetivo mais } \\
\text { gastos gerenciais mensais }\end{array}$ & $\begin{array}{l}\text { A determinação deste fator } \\
\text { envolve a determinação do } \\
\text { organograma e do efetivo } \\
\text { indireto médio mensal da obra, } \\
\text { além da determinação dos } \\
\text { custos gerenciais médios } \\
\text { mensais }\end{array}$ & $\begin{array}{l}\mathrm{R} \$ 154.000,00 \text { de custos } \\
\text { indiretos médios mensais, } \\
\text { sendo } \mathrm{R} \$ 100.000,00 \\
\text { referentes aos salários de } \\
\text { equipe e } \mathrm{R} \$ 54.000,00 \\
\text { referentes aos custos de } \\
\text { manutenção de canteiro }\end{array}$ \\
\hline Mat'0 & $\begin{array}{l}\text { Custos total dos materiais } \\
\text { para a elaboração da obra }\end{array}$ & $\begin{array}{l}\text { A determinação deste fator } \\
\text { envolve a multiplicação de todos } \\
\text { os quantitativos de serviços da } \\
\text { obra levantados multiplicados } \\
\text { por suas respectivas } \\
\text { composições para materiais }\end{array}$ & $\begin{array}{l}\mathrm{R} \$ 350.000,00 \text { de custos } \\
\text { s de aquisição de materiais, } \\
\text { sendo compostos por } \\
\text { todos os materiais } \\
\text { necessários à execução } \\
\text { da obra: cimento, brita, } \\
\text { tijolos, entre outros }\end{array}$ \\
\hline Sm & $\begin{array}{l}\text { Salário Médio Mensal dos } \\
\text { Funcionários de Produção }\end{array}$ & $\begin{array}{l}\text { A determinação deste valor } \\
\text { deve ser feita pela média } \\
\text { ponderada dos salários da } \\
\text { produção e seus respectivos } \\
\text { quantitativos }\end{array}$ & $\begin{array}{l}\mathrm{R} \$ 3.158,47 \text { - Valor de } \\
\text { salários médios dos } \\
\text { funcionários de produção } \\
\text { da obra ponderados pelas } \\
\text { quantidades. }\end{array}$ \\
\hline A & Custo Rescisões & $\begin{array}{l}\text { A determinação dos custos das } \\
\text { rescisões trabalhistas envolve a } \\
\text { aplicação e análise de } \\
\text { parâmetros setoriais e de } \\
\text { legislação que contemplam os } \\
\text { passivos que ocorrem durante a } \\
\text { rescisão dos funcionários. } \\
\text { Fatores como aviso prévio, } \\
\text { aviso prévio indenizado, férias, } \\
13^{\circ} \text { proporcional, multas de } \\
\text { FGTS, entre outros, devem ser } \\
\text { considerados }\end{array}$ & $\begin{array}{l}\text { Índice } 1,85 \text {, ou seja, para } \\
\text { cada funcionário } \\
\text { contratado que será } \\
\text { demitido no futuro, } 1,85 \\
\text { salário adicional deverá } \\
\text { ser pago }\end{array}$ \\
\hline B & Redução de Produtividade & $\begin{array}{l}\text { Deve ser determinada uma } \\
\text { constante fixa que seja } \\
\text { inversamente variável ao prazo } \\
\text { e que determine a redução da } \\
\text { produtividade em decorrência } \\
\text { das reduções de prazo do } \\
\text { projeto }\end{array}$ & $\begin{array}{l}\text { Constante de } 1,12 \text {, ou } \\
\text { seja, aumento nos custos } \\
\text { de mão de obra em } 12 \% \\
\text { em função das perdas de } \\
\text { produtividade. Quanto } \\
\text { mais pessoas trabalhando } \\
\text { em uma mesma atividade, }\end{array}$ \\
\hline
\end{tabular}




\begin{tabular}{|c|c|c|c|}
\hline & & & $\begin{array}{l}\text { maior a chance do } \\
\text { aumento de } \\
\text { improdutividade. É um } \\
\text { fator empírico e deve ser } \\
\text { estimado baseado na } \\
\text { experiência do } \\
\text { orçamentista }\end{array}$ \\
\hline C & $\begin{array}{l}\text { Custo de Mobilização } \\
\text { dos Equipamentos }\end{array}$ & $\begin{array}{l}\text { A determinação dos custos de } \\
\text { mobilização dos equipamentos } \\
\text { envolve a determinação das } \\
\text { distâncias de onde os } \\
\text { equipamentos vão sair até a } \\
\text { obra e a cotação ou estimativa } \\
\text { dos preços para que tal } \\
\text { transporte seja efetuado. A } \\
\text { partir da determinação destes } \\
\text { fatores para cada um dos } \\
\text { equipamentos, os custos podem } \\
\text { ser calculados }\end{array}$ & $\begin{array}{l}\mathrm{R} \$ 856,00 \text { de custos } \\
\text { médios para a } \\
\text { mobilização de cada um } \\
\text { dos equipamentos. }\end{array}$ \\
\hline D & Custo Canteiro de Obras & $\begin{array}{l}\text { A determinação dos custos dos } \\
\text { canteiros de obras e instalações } \\
\text { deve ser feita conforme } \\
\text { cotações de preços para esta } \\
\text { implantação, do uso do histórico } \\
\text { existente na empresa e por } \\
\text { estimativas existentes em } \\
\text { revistas técnicas e } \\
\text { especializadas }\end{array}$ & $\begin{array}{l}\mathrm{R} \$ 763,00 \text { por funcionário } \\
\text { Com o aumento do } \\
\text { número de funcionários } \\
\text { no projeto devido à } \\
\text { redução de prazos, as } \\
\text { estruturas de canteiro } \\
\text { devem aumentar, desta } \\
\text { forma uma média de } \\
\text { acréscimo de custo por } \\
\text { funcionário deve ser } \\
\text { estabelecida }\end{array}$ \\
\hline$E$ & Custos QSMS, treinamentos & $\begin{array}{l}\text { A determinação dos custos de } \\
\text { treinamentos de QSMS deve } \\
\text { ser feita através da estimativa } \\
\text { das horas médias expendidas } \\
\text { durante os treinamentos } \\
\text { necessários de QSMS da } \\
\text { empresa, integrações e } \\
\text { atividades complementares. A } \\
\text { partir da determinação do tempo } \\
\text { médio expendido para tais } \\
\text { atividades, multiplica-se tal valor } \\
\text { pelo valor médio horário do } \\
\text { funcionário }\end{array}$ & $\begin{array}{l}\mathrm{R} \$ 45,30 \text { é o custo de } \\
\text { treinamentos que cada } \\
\text { funcionário tem ao entrar } \\
\text { no projeto devido às } \\
\text { integrações, aos } \\
\text { treinamentos de } \\
\text { qualidade, entre outros }\end{array}$ \\
\hline $\mathrm{F}$ & $\begin{array}{l}\text { Custos EPI + Exames } \\
\text { médicos }\end{array}$ & $\begin{array}{l}\text { A determinação dos custos de } \\
\text { ferramentas adicionais e dos } \\
\text { EPls que a empresa fornece } \\
\text { aos funcionários também deve } \\
\text { ser realizada a partir de } \\
\text { cotações de preços e média de } \\
\text { gastos estimados. Estes fatores } \\
\text { se caracterizam por ter uma } \\
\text { quantidade fixa durante o início } \\
\text { e término do projeto (exames } \\
\text { admissionais e demissionais) e } \\
\text { também por substituição ou } \\
\text { acompanhamento (exames }\end{array}$ & $\begin{array}{l}\mathrm{R} \$ 143,50 \text { fixos + } \mathrm{R} \$ 7,32 \\
\text { por mês por funcionário. } \\
\text { Os } \mathrm{R} \$ 143,50 \text { podem ser } \\
\text { computados como os } \\
\text { custos de exames } \\
\text { admissionais e } \\
\text { demissionais que cada } \\
\text { funcionário deverá fazer, } \\
\text { além da soma dos } \\
\text { uniformes e EPls que } \\
\text { cada funcionário recebe. } \\
\text { Os } R \$ 7,32 \text { são referentes } \\
\text { aos custos de trocas e }\end{array}$ \\
\hline
\end{tabular}




\begin{tabular}{|c|c|c|c|}
\hline & & periódicos) & $\begin{array}{l}\text { substituição de uniformes } \\
\text { e EPls, além dos custos } \\
\text { médios de exames } \\
\text { periódicos }\end{array}$ \\
\hline G & $\begin{array}{l}\text { Economia de Escala - } \\
\text { Suprimentos }\end{array}$ & $\begin{array}{l}\text { A determinação desta constante } \\
\text { inversamente proporcional ao } \\
\text { prazo implica em estimar algum } \\
\text { desconto no valor de todos os } \\
\text { materiais que serão adquiridos } \\
\text { no projeto. A compra de um } \\
\text { quantitativo expressivo em um } \\
\text { prazo menor gera economia de } \\
\text { escala e proporciona maiores } \\
\text { descontos nas negociações }\end{array}$ & $\begin{array}{l}4 \% \text { de economia no valor } \\
\text { total dos materiais do } \\
\text { projeto em função da } \\
\text { economia gerada ao se } \\
\text { comprar os materiais em } \\
\text { ordens de compras mais } \\
\text { expressivas }\end{array}$ \\
\hline $\mathrm{R}$ & Índice de Rotatividade de MO & $\begin{array}{l}\text { A determinação do índice de } \\
\text { rotatividade de MO é obtida } \\
\text { através da experiência prévia do } \\
\text { orçamentista e das memórias } \\
\text { existentes de projetos em obras } \\
\text { e regiões similares }\end{array}$ & $\begin{array}{l}\text { Índice } 1,30 \text {, o qual majora } \\
\text { o quantitativo de mão de } \\
\text { obra calculado devido à } \\
\text { rotatividade da equipe }\end{array}$ \\
\hline S & $\begin{array}{l}\text { Percentual de MO não } \\
\text { subcontratada }\end{array}$ & $\begin{array}{l}\text { A determinação do percentual } \\
\text { de MO não subcontratada } \\
\text { envolve a expertise do } \\
\text { orçamentista determinar o tipo } \\
\text { de obra e o percentual médio de } \\
\text { serviços especializados que } \\
\text { normalmente são } \\
\text { subcontratados. Algumas obras } \\
\text { inclusive possuem instrumentos } \\
\text { contratuais que limitam ou } \\
\text { exigem um percentual mínimo } \\
\text { de subcontratação }\end{array}$ & $\begin{array}{l}\text { Percentual } 75 \% \text {, ou seja, } \\
75 \% \text { do efetivo da obra } \\
\text { será contratado } \\
\text { diretamente pela empresa } \\
\text { construtora, os outros } \\
25 \% \text { serão } \\
\text { subcontratados em } \\
\text { diversas outras empresas } \\
\end{array}$ \\
\hline K & Fator majorador de pico & $\begin{array}{l}\text { A determinação do fator } \\
\text { majorador de pico envolve a } \\
\text { aplicação de um fator de pico } \\
\text { que faz com que seja } \\
\text { considerada a maior quantidade } \\
\text { de funcionários possível durante } \\
\text { a obra. Tal fator pode ser } \\
\text { calculado utilizando-se da } \\
\text { particularidade de as obras } \\
\text { seguirem um padrão de avanço } \\
\text { muito semelhante à Curva S. O } \\
\text { detalhamento de como calcular } \\
\text { está descrito no Item } 2.2\end{array}$ & $\begin{array}{l}\text { Índice 1,6, ou seja, no } \\
\text { pico, a maior quantidade } \\
\text { de funcionários que a } \\
\text { obra possuirá será de } 1,6 \\
\text { multiplicado pela } \\
\text { quantidade média mensal } \\
\text { de funcionários (que pode } \\
\text { ser determinada por M't } \\
\text { dividido pelo prazo da } \\
\text { obra) }\end{array}$ \\
\hline $\mathrm{H}$ & Aumento de Horas Extras & $\begin{array}{l}\text { Constante fixa inversamente } \\
\text { proporcional ao prazo do } \\
\text { projeto. Ao se reduzir o prazo } \\
\text { de um projeto, além de ser } \\
\text { gerados recursos de MO } \\
\text { adicionais, há uma tendência de } \\
\text { elevação nas horas extras (que } \\
\text { são mais caras que as horas } \\
\text { normais) }\end{array}$ & $\begin{array}{l}\text { 13\%, valor de aumento } \\
\text { nos custos devidos }\end{array}$ \\
\hline
\end{tabular}


É importante ressaltar que a determinação dos diversos fatores elencados acima envolve cálculos complexos e que certamente exigem o uso de softwares de mercado disponíveis. Alguns exemplos de softwares são Microsoft Excel e Project, Primavera P3, SAP, ou softwares previamente adaptados para a empresa, como, por exemplo, os da Totvs.

Para o cálculo dos fatores $B, G$ e H, foram utilizadas as Equações (22), (23) e (24).

$$
\begin{gathered}
B(t)=\frac{1}{t} \times \text { Perda Máxima de Produtividade } \\
G(t)=\frac{1}{t} \times \text { Desconto máximo } G \\
H(t)=\frac{1}{t} \times \text { Aumento máximo de horas extras }
\end{gathered}
$$

Onde t é o prazo do Projeto.

\section{3ㄹ Etapa - Determinação do prazo ótimo teórico}

A partir da determinação dos 16 parâmetros do item anterior, o orçamentista já estará munido de informações suficientes para o cálculo da curva dos custos variáveis e para a determinação do prazo ótimo. Basta fazer a substituição dos parâmetros nas Equações (16) e (18).

$$
\begin{aligned}
& C T A_{t}=\left(K R S \frac{M^{\prime}{ }_{t}}{t} S_{m}(A)+M^{\prime}{ }_{t} S_{m} \frac{(B+H)}{t}+\frac{E q^{\prime}{ }_{t}}{t}(C)\right. \\
& \left.+K R S \frac{M^{\prime}{ }_{t}}{t}(D+E+F)-M a t^{\prime}{ }_{0} \frac{(G)}{t}\right)+\left(C I^{\prime}{ }_{t} \times t\right) \\
& t_{\text {ótimo }}=\sqrt{\frac{\operatorname{KRSM}_{t}{ }_{t}\left(A S_{m}+D+E+F\right)+M^{\prime}{ }_{t} S_{m}(B+H)+E q^{\prime}{ }_{t}(C)-M a t^{\prime}{ }_{0}(G)}{C I^{\prime}{ }_{t}}}
\end{aligned}
$$

\section{Etapa - Estudo da curva de custos variáveis}

Conforme abordado em todo o Item 3.1.1 e em seus subitens, a identificação do formato da curva e seu ponto ótimo gerado pelas Equações (16) e (18) possibilita ao 
orçamentista deter o conhecimento sob a potencialidade de geração de economia do projeto com as variações do prazo. Detendo tal conhecimento, o orçamentista possui uma excelente ferramenta para a identificação do tipo de projeto que está lidando.

Esta etapa é fundamental e serve como ponto-chave para o orçamentista ou a empresa decidir se dará continuidade na análise nas etapas $5^{\underline{a}}, 6^{\underline{a}}$ e $7^{\underline{a}}$, ou encerrará a análise da variabilidade entre custos, pois ela se mostrou ineficaz para este tipo específico de projeto.

5- Etapa - Verificação se o prazo estimado inicialmente é maior ou menor que o prazo ótimo determinado

No caso da identificação de alto potencial de economia com as reduções de prazo, cabe ao orçamentista identificar se o prazo inicialmente concebido para o projeto é maior ou menor que o prazo ótimo calculado pela Equação (18).

Caso o prazo ótimo seja menor que o prazo inicialmente concebido para o projeto, o orçamentista deve fazer a reprogramação do cronograma ao menor prazo possível que se aproxime do prazo ótimo caso o objetivo seja a redução dos custos.

Caso o prazo ótimo seja maior que o prazo inicialmente concebido, o orçamentista deve estar ciente de que o projeto se encontra em uma região de alta variabilidade de custos conforme a variação dos prazos, fato que eleva o potencial risco do projeto, neste caso, o orçamentista deve aumentar o cronograma do projeto para o prazo ótimo pré-determinado caso o objetivo seja a redução dos custos.

Caso o prazo ótimo já seja igual ao prazo pré-concebido para o projeto, a análise está finalizada e o prazo deve ser mantido.

6aㅡ Etapa - Recálculo e determinação do cronograma ao ponto-limite de acordo com a definição adotada na etapa anterior

Nesta etapa, o orçamentista deve fazer análises do cronograma do projeto aumentar ou reduzir os prazos conforme determinado no item anterior.

Quando o caso é de aumento do prazo, tal atividade não exige alta complexidade, uma vez que esta atividade não envolve etapas críticas e o cronograma se mostra muito mais flexível.

Já a redução dos prazos é muito mais complexa, pois certas atividades do projeto possuem prazos que não podem ser reduzidos devido às restrições tecnológicas, como, por exemplo, cura e resistência do concreto, duração de um tipo específico de fundação, entre outros. Neste caso, o orçamentista adequa o cronograma ao período mínimo possível, respeitando todas as limitações de prazo destas atividades que exigem cuidado especial. Neste ponto, cabe ao orçamentista determinar o crash time, conforme abordado no Item 2.3.

$7^{\text {a }}$ Etapa - Cálculo final do potencial de economia utilizando parâmetros do cronograma recalculado

Uma vez que foi estabelecido o novo prazo que mais se aproxima do prazo ótimo pré-concebido, o cálculo final do potencial de economia a ser gerado pelo aumento 
ou pela redução de prazos é um ótimo indicador. Tal valor pode ser determinado pelo uso da Equação (19).

$$
\begin{aligned}
\Delta C A_{t_{\text {ótimo }}}=( & K R S \frac{M^{\prime}{ }_{t}}{t} S_{m}(A)+M^{\prime}{ }_{t} S_{m} \frac{(B+H)}{t}+\frac{E q^{\prime}{ }_{t}}{t}(C) \\
& \left.+K R S \frac{M^{\prime}{ }_{t}}{t}(D+E+F)-M a t^{\prime}{ }_{0} \frac{(G)}{t}+C I^{\prime}{ }_{t} \times t\right) \\
& -\left(K R S \frac{M^{\prime}{ }_{t}}{t_{\text {ótimo }}} S_{m}(A)+M^{\prime}{ }_{t} S_{m} \frac{(B+H)}{t_{\text {ótimo }}}+\frac{E q^{\prime}{ }_{t}}{t_{\text {ótimo }}}(C)\right. \\
& \left.+K R S \frac{M^{\prime}{ }_{t}}{t_{\text {ótimo }}}(D+E+F)-M a t^{\prime}{ }_{0} \frac{(G)}{t_{\text {ótimo }}}+C I^{\prime}{ }_{t} \times t_{\text {ótimo }}\right)
\end{aligned}
$$

A partir do cálculo do valor de economia com a variabilidade dos prazos, a empresa certamente possui um melhor direcionamento e competitividade para a participação de concorrências de projetos, além de certamente um melhor conhecimento do projeto em si. 


\section{ESTUDOS DE CASO}

Neste tópico, serão feitos dois estudos de caso com a aplicação do método proposto. O primeiro estudo será de uma obra de infraestrutura pesada - ponte de $1,6 \mathrm{Km}$, e o segundo caso será de um condomínio residencial.

Ressalta-se o primeiro estudo de caso é o mais importante no contexto deste trabalho, uma vez que o autor já era bastante familiarizado com os orçamentos em obras de infraestrutura pesada. O segundo caso foi feito para fins comparativos, mas o autor não tinha tanta familiaridade nestas orçamentações quando comparado ao primeiro caso.

O estudo prático em dois tipos distintos de obras objetiva avaliar a aplicabilidade do método aqui proposto e as diferenças que ocorrem em cada um dos tipos.

\subsection{ESTUDO DE CASO 1 - PONTE 1,6 KM}

Para a aplicação da metodologia, utiliza-se todas as sete etapas desenvolvidas no Item 3.1.4.

\subsubsection{CARACTERIZAÇÃO DO OBJETO}

- O escopo do projeto é a execução de serviços necessários para a construção de uma ponte rodoviária sobre rio e seus acessos à rodovia. A ponte possui extensão de $1,6 \mathrm{Km}$ e é composta por elementos pré-moldados até a transposição do canal, onde é utilizado o método de balanço sucessivo para vencer um vão de 100 metros. Faz também parte do escopo a implantação de rodovia em pista simples, incluindo serviços de terraplanagem, drenagem e pavimentação flexível, totalizando $4,5 \mathrm{Km}$.

- Regime de Contratação: 8.666/93 - Regime de Empreitada por Preço Unitário

- Modo de disputa: Sessão de entrega da Proposta Comercial

- Preço-base órgão: R\$ 150 MM (Base 2016)

- Prazo de Contrato Original Proposto: 36 meses

- Principais atividades:

- Terraplanagem;

- Pavimentação;

- Estacas escavadas em solo e rocha com apoio náutico;

- Mesoestrutura com apoio náutico;

- Vigas pré-moldadas com lançamento de treliças; 
- Balanço sucessivo.

- Área para canteiro de obra e industrial: aproximadamente $16.000 \mathrm{~m}^{2}$, sendo a cobertura vegetal de gramíneas rasteiras. Não é necessária a supressão de indivíduos arbóreos.

- Valores do orçamento: ano de 2017.

Plantas e referências do projeto e maior detalhamento dos sistemas construtivos: Inicialmente segue toda a planta do perfil da ponte a ser construída.

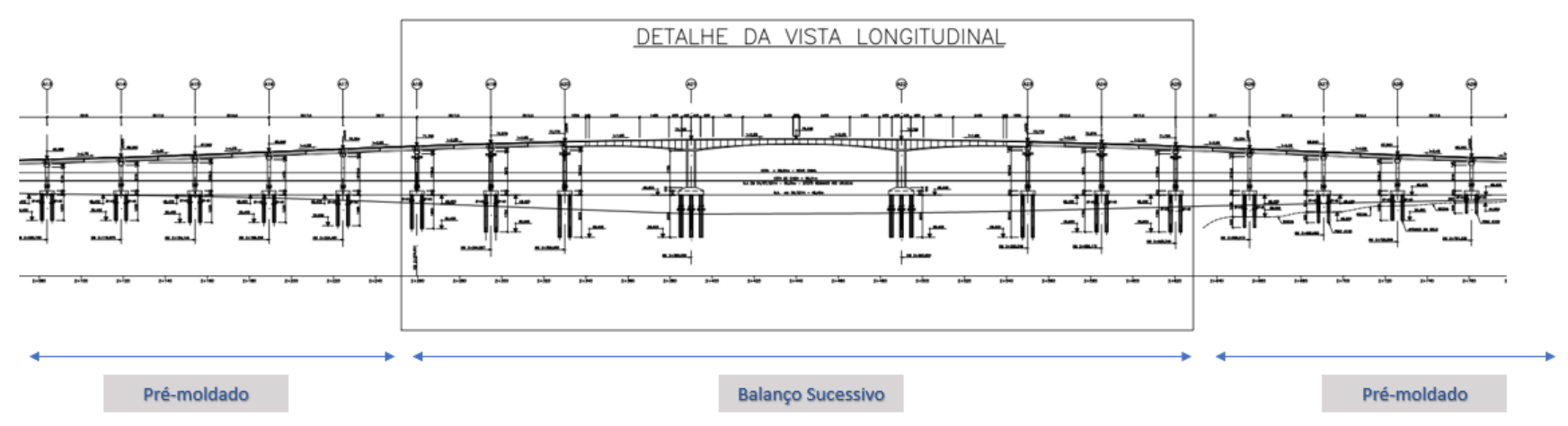

Figura 3 - Perfil da ponte a ser construída. Fonte: Autor

\section{Infraestrutura e fundações}

- Estacas: as estacas da ponte foram concebidas em estaca escavada em solo sob o leito do rio. Os diâmetros variam de $1,40 \mathrm{~m}$ a 1,60 m.

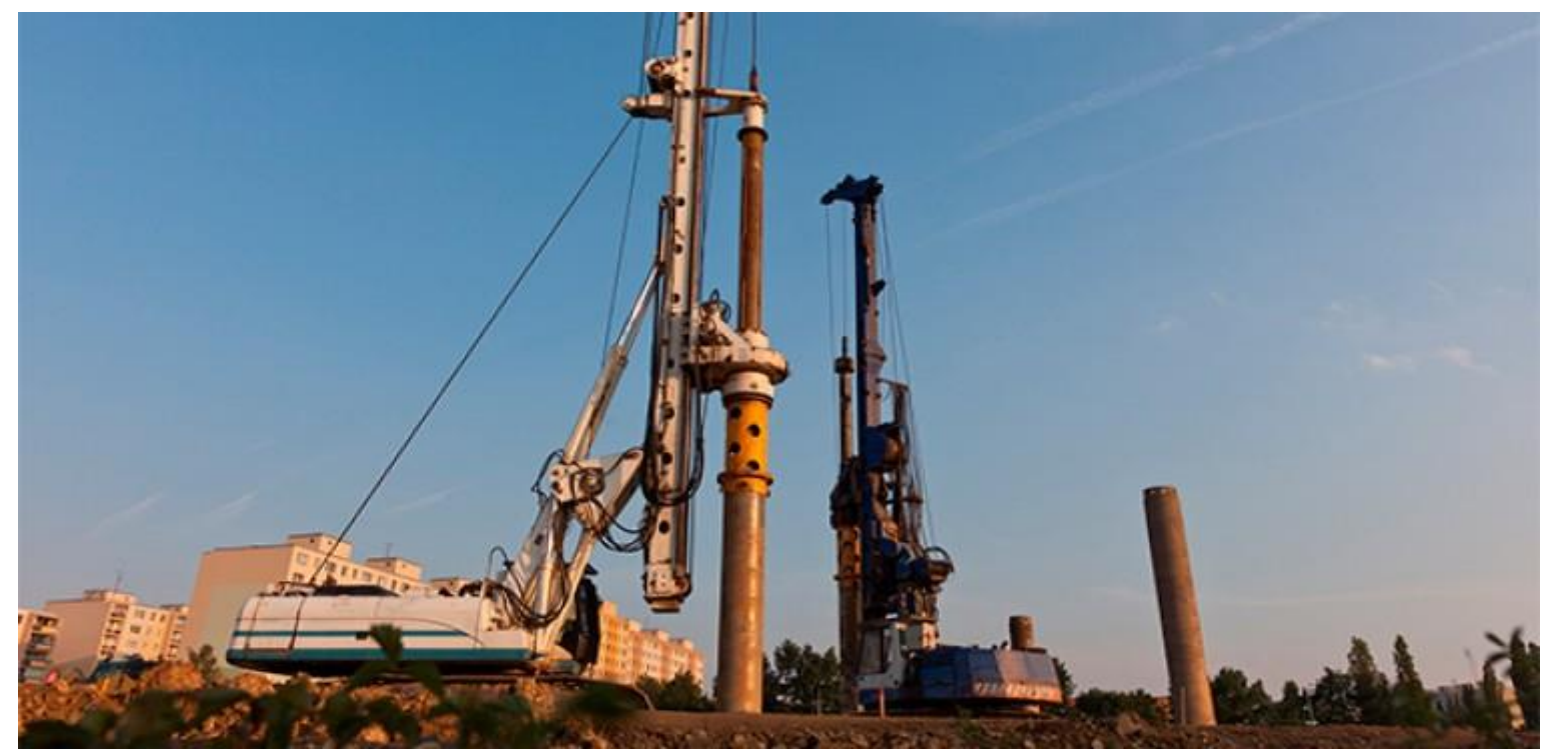

Figura 4 - Exemplo de metodologia de execução de estacas escavadas.

Fonte: https://www.topempresas.com.br/perfuratriz-estaca-escavada 
- Blocos: mais de 3 mil $\mathrm{m}^{3}$ de concreto de blocos executados, alguns executados em solo, outros sobre o leito do rio. A seguir, seguem exemplos da metodologia executiva e dos blocos sobre o leito do rio.

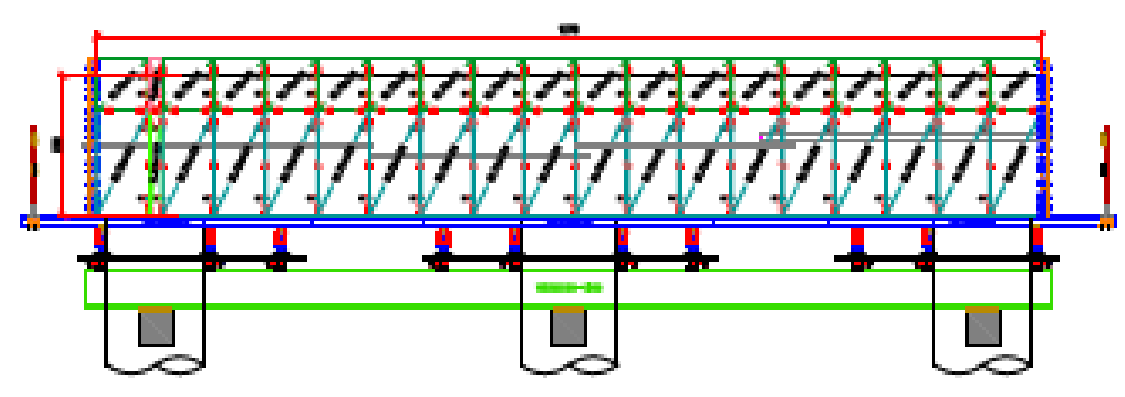

ockerrem

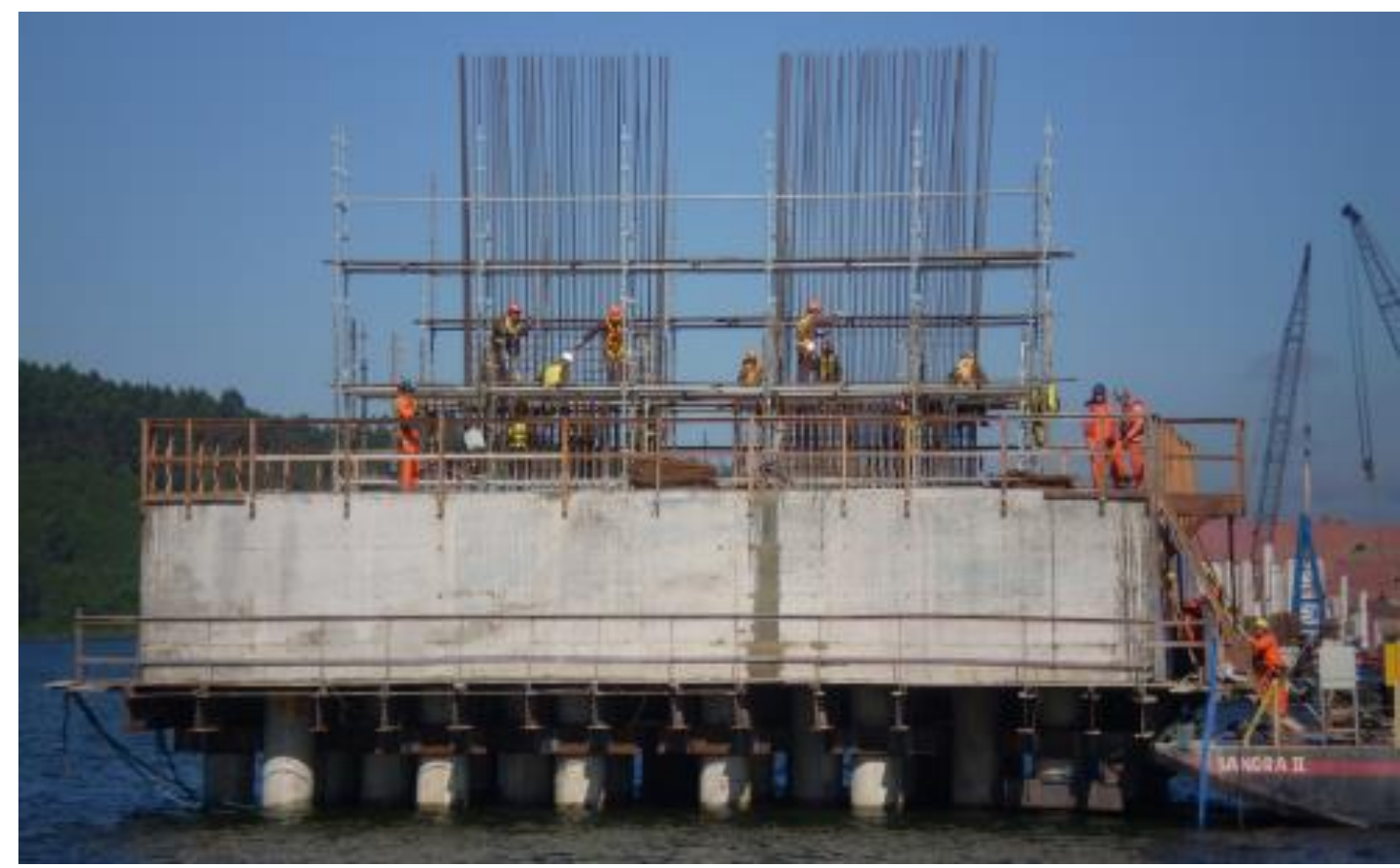

Figura 5 - Exemplo de metodologia executiva de blocos. Fonte: Autor

\section{Mesoestrutura}

- Pilares: pilares circulares executados em forma trepante, além de pilares parede em forma retangular para os vãos centrais.

As formas trepantes são constituídas de módulos metálicos, enrijecidos e contraventados horizontal e verticalmente com perfis metálicos com andaimes laterais e inferiores acoplados à estrutura da forma. A movimentação ascensional da forma de cada lance de concretagem para o subsequente será feita através de macacos hidráulicos, acionados por bombas hidráulicas. 


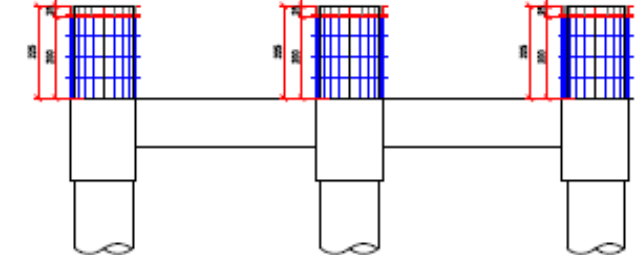

CORTE AA-1 1 ETAPA

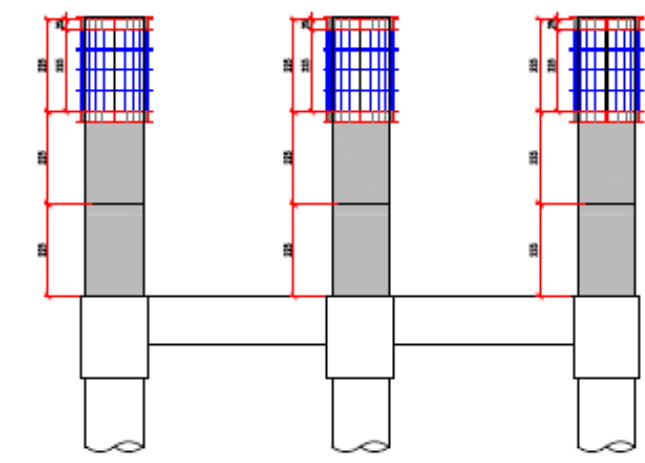

CORTE AA - - ${ }^{2}$ ETAPA

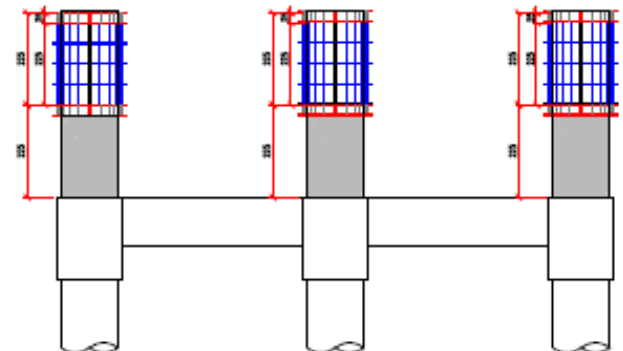

CORTE AA-ZZETAPA

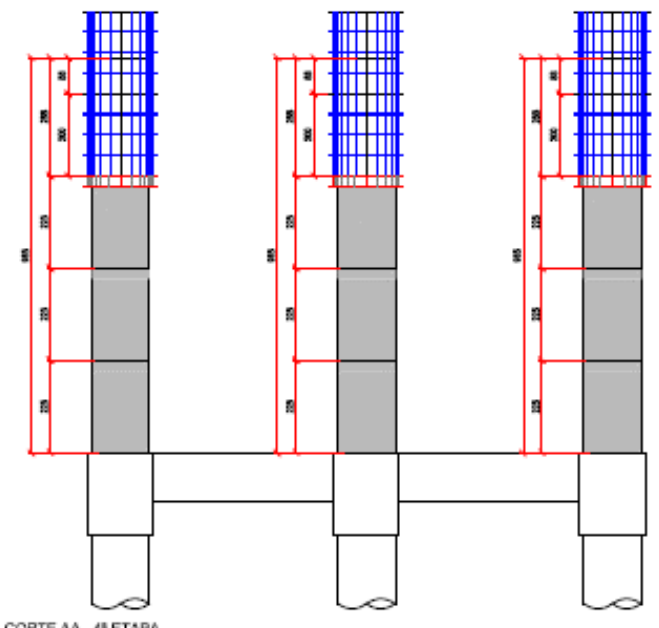

CORTE AA- A*ETAPA

Figura 6 - Pilares executados em formas trepantes - Lances de concretagem. Fonte: Autor

- Travessas: as travessas são estruturas retangulares de concreto moldadas in loco. Elas servirão de apoio para as futuras vigas pré-moldadas. 


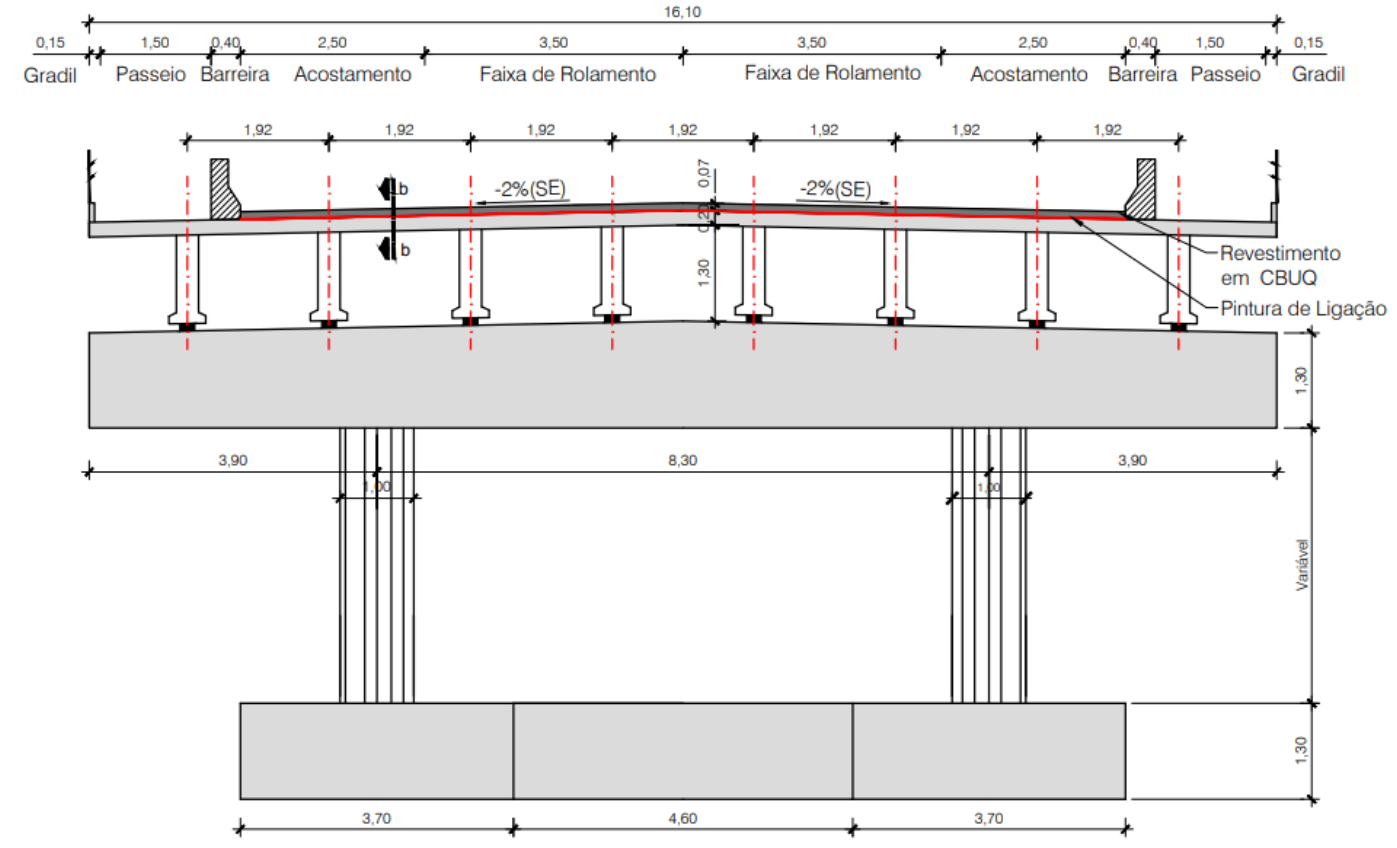

Figura 7 - Travessas moldadas in loco - Vista superior do Pilar. Fonte: Autor

\section{Superestrutura}

- Vigas: A concepção do projeto apresenta elementos pré-moldados desde os acessos até a transposição do canal de navegação na calha do rio. A utilização de vigas pré-moldadas protendidas tem a vantagem de ser executada concomitantemente com outras etapas da obra, bem como permitir - lançamento dessas vigas através de treliças ao longo dos apoios sem a utilização de escoramento. As vigas pré-moldadas chegam a ter 35 metros de comprimento e possuem formas apresentadas na Figura 8.
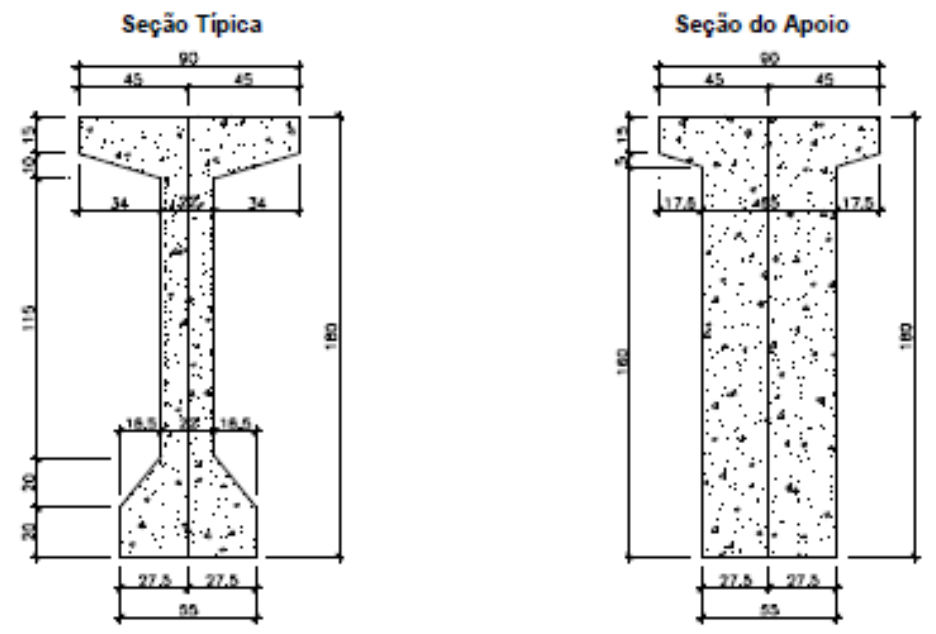

Figura 8 - Seção típica das vigas pré-moldadas e protendidas. Fonte: Autor 


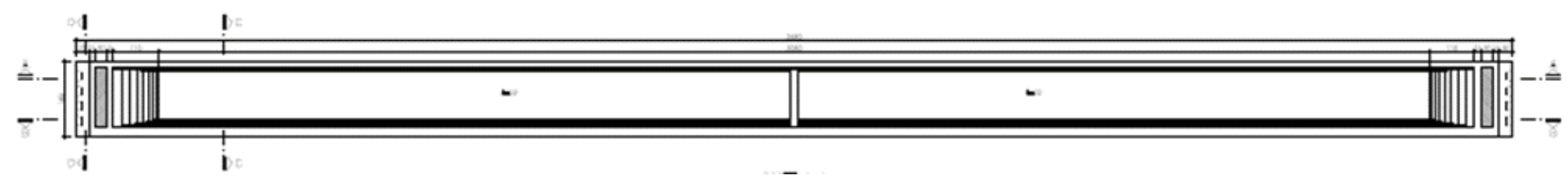

Figura 9 - Seção transversal de vigas pré-moldadas. Fonte: Autor

- Carrelones: a metodologia de transporte das vigas pré-moldadas do canteiro de obras até o ponto de içamento das treliças lançadeiras é feita através de carrelones. Os carrelones são equipamentos que são compostos de dois pórticos móveis com capacidade de até 70 toneladas, montados sobre pneus, que são desprovidos de tração e necessitam de uma carregadeira (Tipo CAT 930 ou 960) para a tração do conjunto e o transporte das vigas.
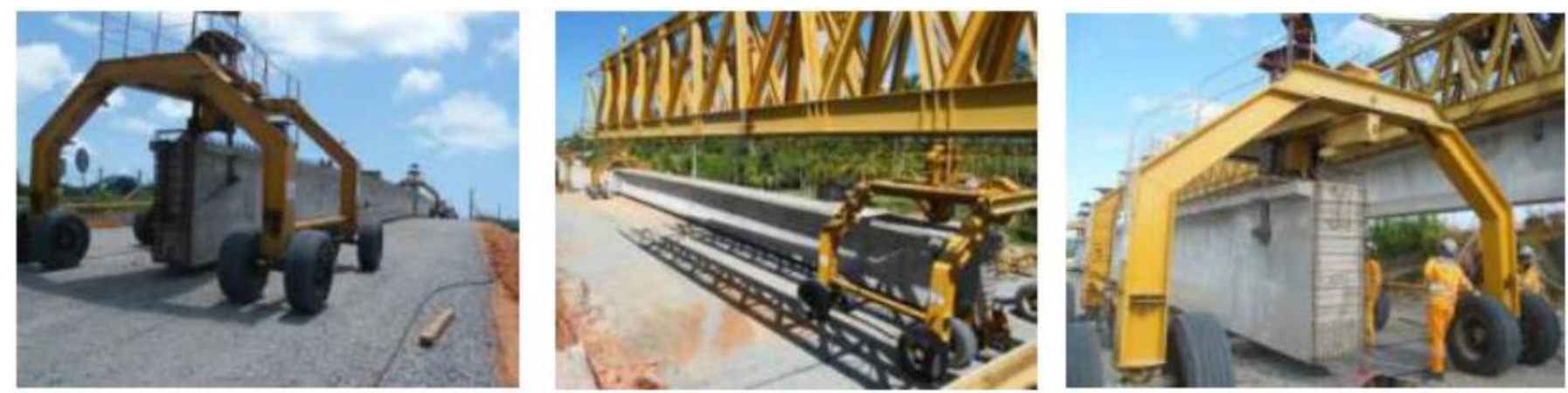

Figura 10 - Carrelones para o transporte de vigas pré-fabricadas. Fonte: Autor

- Treliças lançadeiras: a metodologia de montagem das vigas prémoldadas será feita por meio de treliças lançadeiras. $O$ equipamento opera sobre apoios especiais deslocando vigas desde a cabeceira da ponte até os respectivos apoios. Tais treliças têm capacidade de lançar vigas de até 140 toneladas e para vãos de até 45 metros. Além dos módulos treliçados principais, o conjunto da treliça é composto por torres, binários, carrinhos, fisquetes e gerador. 


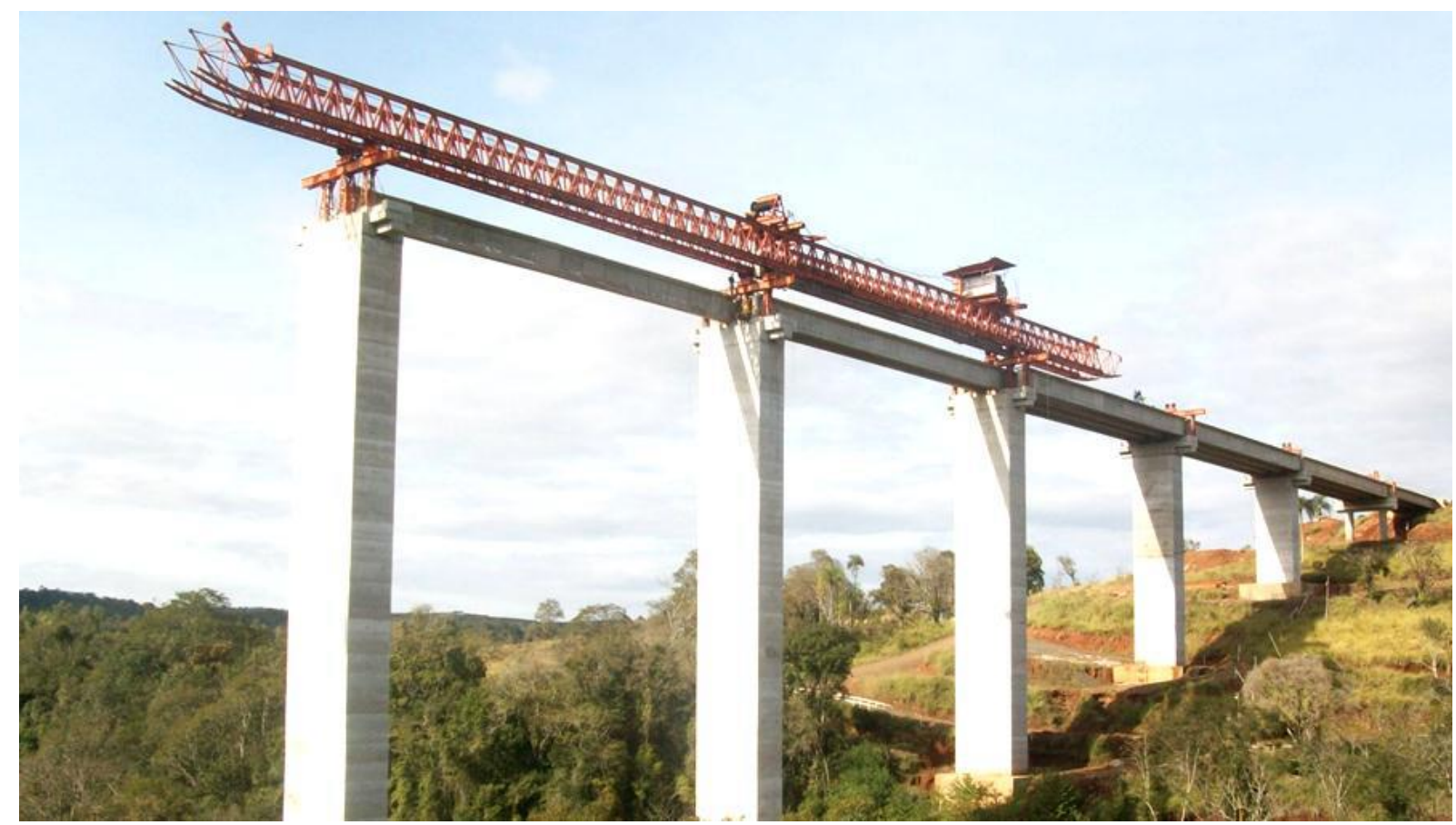

Figura 11 - Treliça lançadeira de vigas. Fonte: Autor

- Tabuleiro: possuindo largura de aproximadamente $16 \mathrm{~m}$ e comprimento de $35 \mathrm{~m}$, os tabuleiros são estruturados pelas vigas prémoldadas protendidas e por pequenas placas de pré-lajes. Após toda a montagem dos elementos pré-moldados, é realizado o capeamento do tabuleiro.

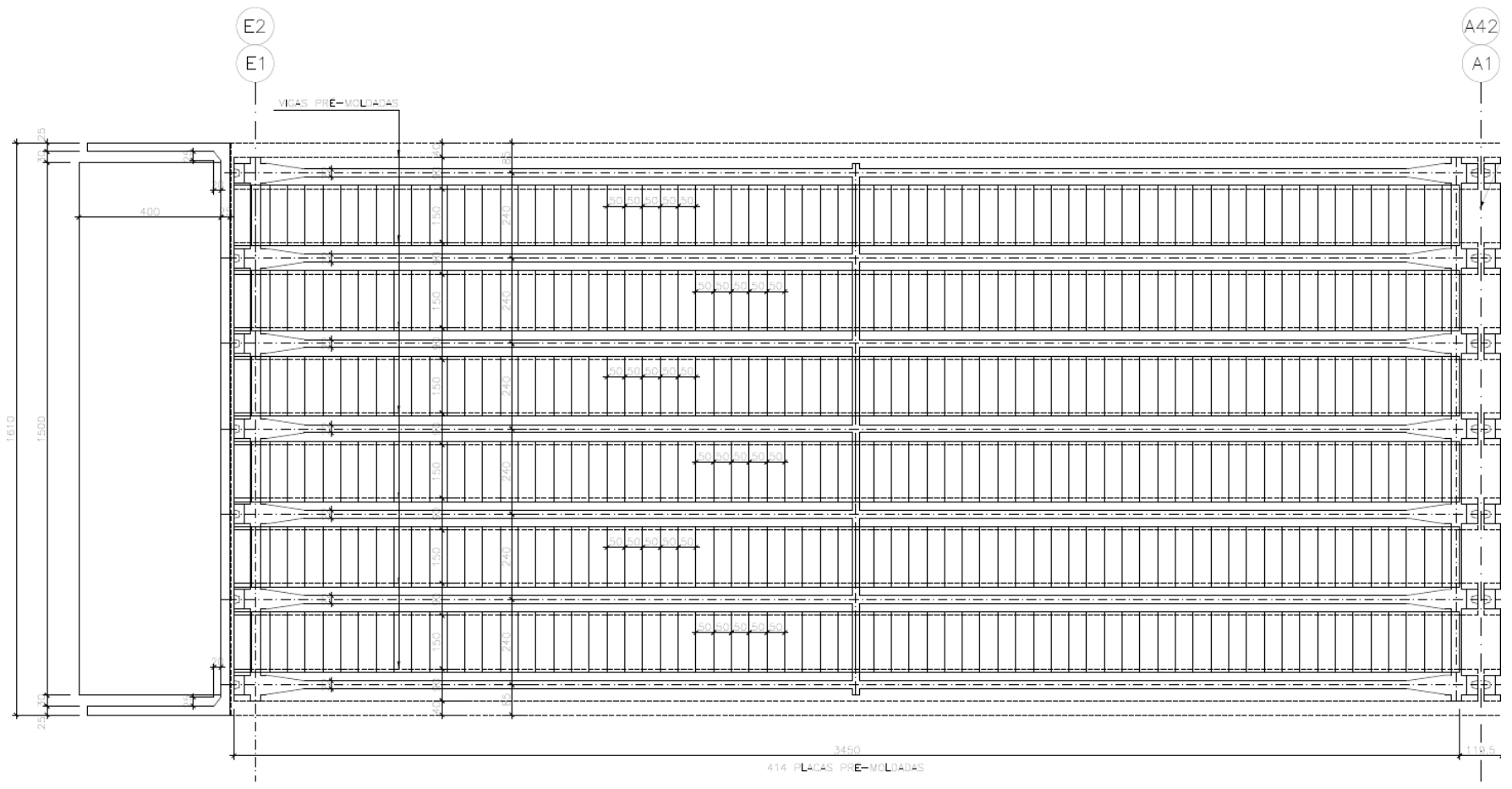

Figura 12 - Tabuleiro da ponte, nas zonas de aproximação do vão central. Fonte: Autor 
- Balanços sucessivos: Em função da sua capacidade em vencer o vão de $100 \mathrm{~m}$, foi adotada a técnica de balanço sucessivo para a transposição do canal de navegação na calha do rio.
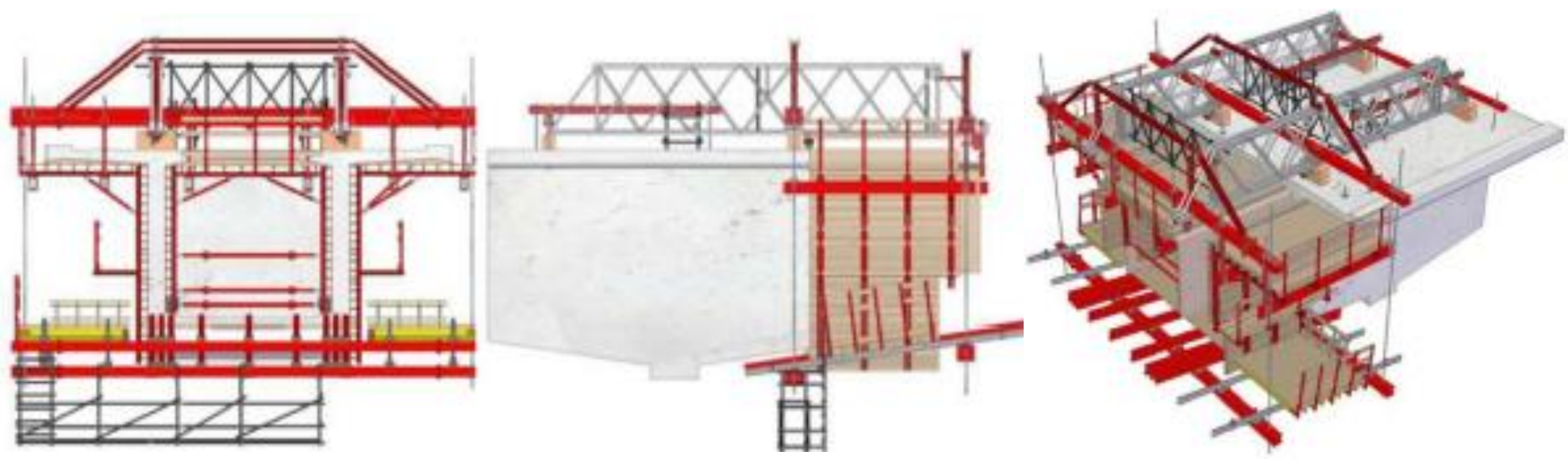

Figura 13 - Metodologia executiva dos balanços sucessivos. Fonte: Autor

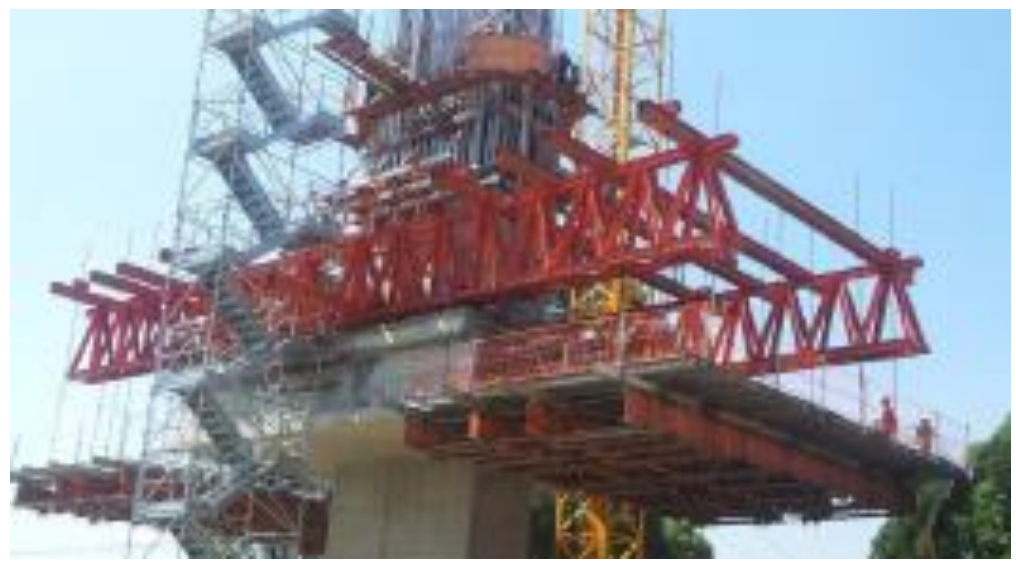

Figura 14 - Metodologia executiva dos balanços sucessivos. Fonte: Autor 


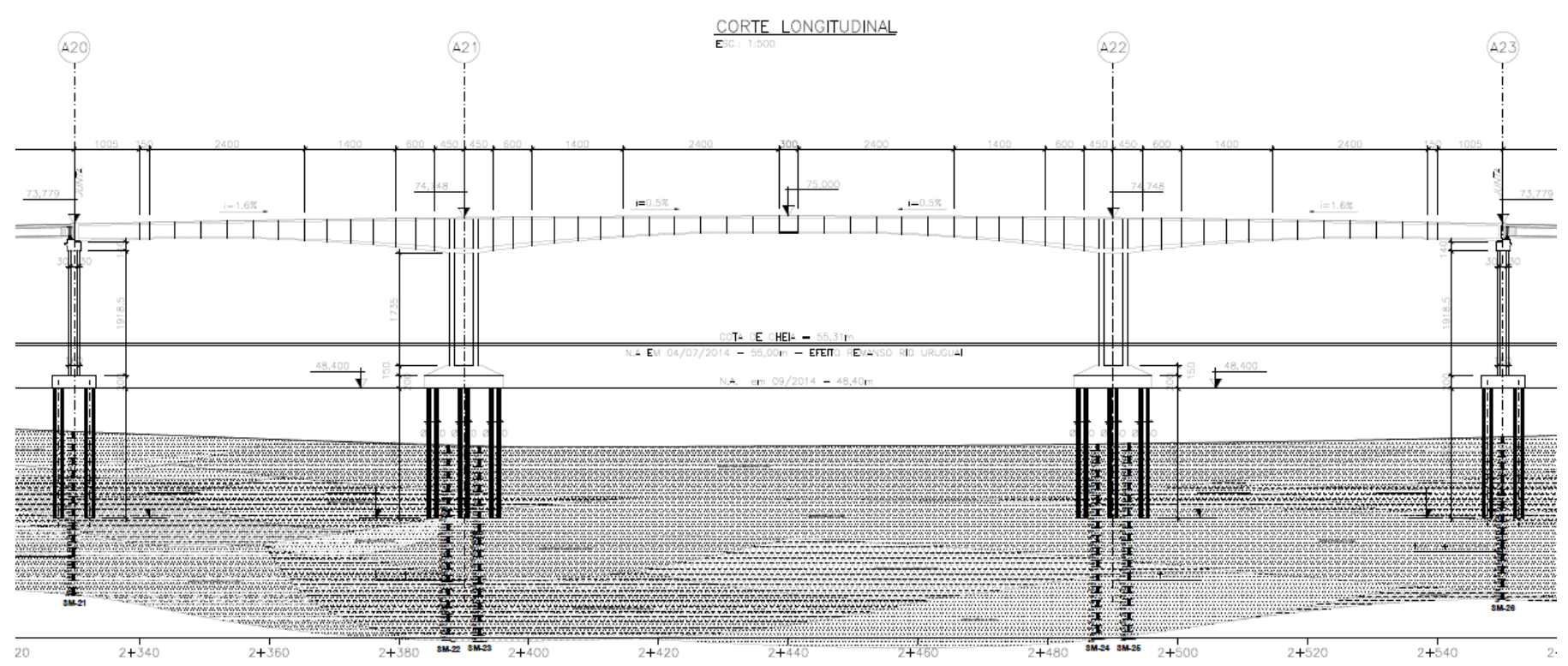

Figura 15 - Balanços sucessivos. Fonte: Autor

\subsubsection{PARÂMETROS DE REFERÊNCIA DAS VARIÁVEIS DA EQUAÇÃO}

Para o cálculo das variáveis das equações dos custos e prazos, deve-se determinar os 16 parâmetros fundamentais para a concepção da curva de variabilidade dos custos e do prazo ótimo teórico, conforme as Equações (16) e (18) e Quadro 13. Do Quadro 14 ao Quadro 39, é apresentada cada uma das variáveis do Quadro 13 particionada juntamente com as memórias e justificativas de cada um dos itens da equação.

Quadro 14 - Identificação dos Indicadores da Equação de Prazo Ótimo - Item M’t

\begin{tabular}{|l|l|l|l|}
\hline Item & Descrição & Determinação & Resultado \\
\hline M't & $\begin{array}{l}\text { Quantitativo total de mão de } \\
\text { obra orçada para a execução } \\
\text { do projeto em um mês }\end{array}$ & $\begin{array}{l}\text { A determinação foi feita pela } \\
\text { multiplicação de todos os } \\
\text { quantitativos de serviços da } \\
\text { obra levantados multiplicados } \\
\text { por suas respectivas } \\
\text { composições para mão de obra }\end{array}$ & $\begin{array}{l}3.469 \text { funcionários, sendo } \\
295 \text { pedreiros, 620 } \\
\text { carpinteiros, 1.764 } \\
\text { serventes, 60 } \\
\text { encarregados, entre } \\
\text { outros }\end{array}$ \\
\hline
\end{tabular}

Com o uso dos dados do Quadro 15, é possível efetuar o cálculo do item M't que equivale ao quantitativo total de mão de obra direta para executar o projeto em apenas um mês. $O$ valor total de homem-hora direta estimada para todo o empreendimento foi de 610.463 horas, e foi obtido através do uso de softwares de cálculo, em que todos os quantitativos de serviços, conforme 0

Quadro 16, foram multiplicados por suas respectivas composições unitárias de serviços. A quantidade do efetivo em um mês foi obtida pela divisão das 610.463 
horas por 176 horas, que é o período médio efetivamente trabalhado pelos funcionários por mês, gerando, assim, uma necessidade de aproximadamente 3.469 funcionários caso o projeto fosse executado em um único mês. Algumas memórias das composições dos serviços podem ser encontradas no Apêndice A.

Quadro 15 - Identificação dos Indicadores da Equação de Prazo Ótimo - Item M’t

\begin{tabular}{|l|c|c|c|c|}
\cline { 2 - 5 } \multicolumn{1}{c|}{} & 176 HH & \multicolumn{3}{c|}{ Ponderações } \\
\hline Função & HH Trab. & Qtde Mês & \multicolumn{2}{c|}{ Salário (R\$) } \\
\hline Armador & 13.206 & 75 & 1.135 & 85.227 \\
\hline Carpinteiro & 109.076 & 619 & 1.835 & 1.137 .41 \\
\hline Pedreiro & 51.771 & 294 & 1.135 & 334.114 \\
\hline Ajudante/servente & 310.448 & 1.763 & 1.106 & 1.952 .365 \\
\hline Operador/marteleteiro/motorista & 113.758 & 646 & 1.213 & 784.141 \\
\hline Eletricista/encanador/soldador/pintor & 1.760 & 10 & 1.135 & 11.358 \\
\hline Encarregado & 10.444 & 59 & 5.032 & 298.621 \\
\hline Total & $\mathbf{6 1 0 . 4 6 3}$ & 3.469 & & $\mathbf{4 . 6 0 3 . 2 4 4 , 4 5}$ \\
\hline Salário Médio & & & & $\mathbf{1 . 3 2 7}$ \\
\hline
\end{tabular}

Quadro 16 - Quantitativo de resumo de serviços

\begin{tabular}{|c|l|c|r|}
\hline Item & \multicolumn{1}{|c|}{ Nome } & Und & Qtde \\
\hline 1 & $\begin{array}{l}\text { Fornecimento, preparo e colocação de Aço CA-50, inclusive mão de } \\
\text { obra }\end{array}$ & KG & 1.263 .727 \\
\hline 2 & $\begin{array}{l}\text { Apoio náutico para a execução das obras (infraestrutura, } \\
\text { mesoestrutura) }\end{array}$ & MÊS & 28 \\
\hline 3 & Lançamento e posicionamento de vigas pré-moldadas de 50 tf & UM & 280 \\
\hline 4 & Concreto estrutural usinado FCK=40 MPA, com bombeamento & M3 & 8.720 \\
\hline 5 & Esc. carga transp. mat 1a cat dmt 3000 a 5000m c/e & M3 & 660.641 \\
\hline 6 & Gabião colchão esp. 0,30m 6x8zn/al+pvc d=2,00mm & M2 & 14.395 \\
\hline 7 & Gabião colchão esp. 0,30m 6x8zn/al+pvc d=2,00mm & M2 & 14.395 \\
\hline 8 & Fornecimento, preparo e colocação de formas Aço CA-50 & KG & 539.544 \\
\hline 9 & Fornecimento, preparo e colocação de formas Aço CA-50 & KG & 535.005 \\
\hline 10 & $\begin{array}{l}\text { Fornecimento, preparo e colocação de Aço CA-50, inclusive mão de } \\
\text { obra }\end{array}$ & KG & 396.143 \\
\hline 11 & Fornecimento e instalação de geogrelhas - Macgrid WG760 & M2 & 26.313 \\
\hline 12 & Fornecimento e instalação de geogrelhas - Macgrid WG760 & M2 & 26.313 \\
\hline
\end{tabular}




\begin{tabular}{|c|l|c|r|}
\hline 13 & Fornec. e lanç de concreto usinado fck=25MPa submerso & M3 & 4.859 \\
\hline 14 & Aço para lajes & KG & 393.660 \\
\hline 15 & Conc.estr.fck=30 MPa-contr.raz.uso ger.conf.e lanç & M3 & 4.552 \\
\hline 16 & Esc. carga transp. mat 1ª cat dmt 8001 a 9000m c/e & M3 & 223.283 \\
\hline 17 & $\begin{array}{l}\text { Cravação de camisa metálica Ø1,40m em solo - equip. sobre } \\
\text { lâmina d'água (P16 ao P24) ) - inc }\end{array}$ & $\mathrm{M}$ & 711 \\
\hline 18 & Concr.estr.fck=30mpa-c.raz.c/a dit.conf.lanc.AC/BC & $\mathrm{M} 3$ & 4.259 \\
\hline 19 & $\begin{array}{l}\text { Fornec. de treliça para balanços sucessivos p/ aduelas de 4,5 m com } \\
\text { capacidade para 100 toneladas }\end{array}$ & $\mathrm{M} 2$ & 3.252 \\
\hline 20 & $\begin{array}{l}\text { Cravação de camisa metálica Ø1,60m - equip. sob lâmina } \\
\text { d'água (P21 E 22) - inc }\end{array}$ & $\mathrm{M}$ & 480 \\
\hline 21 & Esc. carga transp. mat 1ª cat dmt 9000 a 10000m c/e & $\mathrm{M} 3$ & 153.823 \\
\hline 22 & Fornecimento, preparo e colocação de formas aço CA-50 & $\mathrm{KG}$ & 266.830 \\
\hline 23 & Forma de placa compensada resinada & $\mathrm{M} 2$ & 58.384 \\
\hline 24 & Fornecimento, preparo e colocação de formas aço CA-50 & $\mathrm{KG}$ & 298.861 \\
\hline 25 & Concretagem de Lajes & $\mathrm{M} 3$ & 3.280 \\
\hline
\end{tabular}

Além dos quantitativos de horas necessárias, também foi computado o valor de remuneração média ponderada para esses trabalhadores, tal parâmetro também será utilizado mais à frente para o cálculo das rescisões e de outros fatores. O valor final computado foi de $R \$ 1.327$ de remuneração média de base, conforme o Quadro 15 e o Quadro 17.

Quadro 17 - Identificação dos Indicadores da Equação de Prazo Ótimo - Item Sm

\begin{tabular}{|l|l|l|l|}
\hline Item & Descrição & Determinação & Resultado \\
\hline $\mathrm{Sm}$ & $\begin{array}{l}\text { Salário Médio Mensal dos } \\
\text { Funcionários de Produção }\end{array}$ & $\begin{array}{l}\text { A determinação deste valor } \\
\text { deve ser feita pela média } \\
\text { ponderada dos salários da } \\
\text { produção e seus respectivos } \\
\text { quantitativos }\end{array}$ & $\begin{array}{l}\text { R\$ 1.327 - Valor de } \\
\text { salários médios dos } \\
\text { funcionários de produção } \\
\text { da obra ponderados pelas } \\
\text { quantidades, conforme } \\
\text { abordado acima. }\end{array}$ \\
\hline
\end{tabular}

Para o cálculo do fator Mat'0, deve-se somar todos os custos de materiais que compõem a obra. O Quadro 18 contém o resumo dos principais materiais; e o Quadro 19, o seu valor final. 
Quadro 18 - Resumo dos principais materiais da Obra

\begin{tabular}{|l|l|l|l|l|l|}
\hline Item & \multicolumn{1}{|c|}{ Descrição } & Unidade & Quantidade & $\begin{array}{c}\text { Custo } \\
\text { Unitário }\end{array}$ & \multicolumn{1}{c|}{ Custo } \\
\hline 1 & Aço CA-50 - bitola média - Cortado e dobrado & KG & 3.501 .287 & 2,72 & 9.523 .500 \\
\hline 2 & Cimento portland - granel & KG & 11.450 .891 & 0,38 & 4.351 .338 \\
\hline 3 & Geogrelhas - Macgrid WG760 & M2 & 57.889 & 69 & 3.994 .389 \\
\hline 4 & Brita graduada & M3 & 27.149 & 104 & 2.828 .993 \\
\hline 5 & Geogrelhas - Macgrid WG460 & M2 & 71.904 & 30 & 2.193 .096 \\
\hline 6 & $\begin{array}{l}\text { Camisa metálica para estacas escavadas com } \\
\text { D=1,40 m, e=10,00 mm }\end{array}$ & M & 1.286 & 1.638 & 2.108 .191 \\
\hline 7 & $\begin{array}{l}\text { Gabião tipo colchão reno esp. 0,30m 6 x 8zn/al+pvc } \\
\text { d=2,00 mm }\end{array}$ & M2 & 28.790 & 65 & 1.881 .138 \\
\hline 8 & Brita & M3 & 23.411 & 78 & 1.826 .123 \\
\hline 9 & Cordoalha para protensão CP-190 RB, D=12,7mm & KG & 415.950 & 4,09 & 1.701 .236 \\
\hline 10 & Neoprene fretado & KG & 4.300 & 390 & 1.677 .310 \\
\hline 11 & Óleo Diesel S-10 & L & 527.929 & 2,70 & 1.425 .409 \\
\hline 12 & Cimento asfáltico de petróleo - CAP-50/70 & T & 737 & 1.890 & 1.393 .137 \\
\hline 13 & Óleo diesel S-500 & L & 514.398 & 2,62 & 1.347 .723 \\
\hline 15 & $\begin{array}{l}\text { Camisa metálica para estacas escavadas com } \\
\text { D=1,60 m, e=12,5 mm }\end{array}$ & M & 489 & 2.376 & 1.163 .451 \\
\hline 16 & Fornecimento de massa asfáltica - CBUQ & T & 7.059 & 119 & 840.782 \\
\hline 17 & Fornecimento de massa asfáltica - BINDER & T & 6.342 & 119 & 755.403 \\
\hline 18 & Pedra de mão & M3 & 8.068 & 77 & 627.926 \\
\hline 19 & Areia lavada & M3 & 14.800 & 37 & 547.619 \\
\hline
\end{tabular}

Quadro 19 - Identificação dos Indicadores da Equação de Prazo Ótimo - Item Mat'0

\begin{tabular}{|l|l|l|l|}
\hline Item & Descrição & Determinação & Resultado \\
\hline Mat'0 & $\begin{array}{l}\text { Custo total dos materiais para } \\
\text { a elaboração da obra }\end{array}$ & $\begin{array}{l}\text { A determinação deste fator } \\
\text { envolve a multiplicação de todos } \\
\text { os quantitativos de serviços da } \\
\text { obra levantados multiplicados } \\
\text { por suas respectivas } \\
\text { composições para materiais }\end{array}$ & $\begin{array}{l}\text { R\$ção de materiais, } \\
\text { sendo compostos por } \\
\text { todos os materiais } \\
\text { necessários à execução } \\
\text { da obra: cimento, aço, } \\
\text { agregados. }\end{array}$ \\
\hline
\end{tabular}

O Quadro 20 aborda os quantitativos de equipamentos e seus custos de mobilização. 
Quadro 20 - Identificação dos Indicadores da Equação de Prazo Ótimo - Itens Eq't e C

\begin{tabular}{|c|c|c|c|}
\hline Item & Descrição & Determinação & Resultado \\
\hline Eq't & $\begin{array}{l}\text { Quantitativo total de } \\
\text { equipamentos orçados para a } \\
\text { execução do projeto em um } \\
\text { mês }\end{array}$ & $\begin{array}{l}\text { A determinação deste fator foi } \\
\text { feita pela multiplicação de todos } \\
\text { os quantitativos de serviços da } \\
\text { obra levantados multiplicados } \\
\text { por suas respectivas } \\
\text { composições para } \\
\text { equipamentos }\end{array}$ & $\begin{array}{l}685 \text { equipamentos, sendo } \\
32 \text { escavadeiras, } 348 \\
\text { caminhões caçamba, } 21 \\
\text { motoniveladoras, } 42 \\
\text { retroescavadeiras, entre } \\
\text { outros }\end{array}$ \\
\hline C & $\begin{array}{l}\text { Custo Mobilização } \\
\text { Equipamentos }\end{array}$ & $\begin{array}{l}\text { A determinação dos custos de } \\
\text { mobilização dos equipamentos } \\
\text { foi feita pela determinação das } \\
\text { distâncias de onde os } \\
\text { equipamentos vão sair até a } \\
\text { obra e a cotação ou estimativa } \\
\text { dos preços para que tal } \\
\text { transporte seja efetuado. A } \\
\text { partir da determinação destes } \\
\text { fatores para cada um dos } \\
\text { equipamentos, os custos foram } \\
\text { calculados. }\end{array}$ & $\begin{array}{l}\mathrm{R} \$ 2.049 \text { de custos } \\
\text { médios para a } \\
\text { mobilização de cada um } \\
\text { dos equipamentos. }\end{array}$ \\
\hline
\end{tabular}

Com o uso dos dados do Quadro 21, foi possível efetuar o cálculo do item Eq’t que equivale ao quantitativo total de equipamentos para executar o projeto em apenas um mês. $O$ valor total de horas de equipamentos a ser trabalhadas, apresentado na primeira coluna da tabela e que totaliza 120.479 horas no projeto, foi também obtido através do uso de softwares de cálculo, em que todos os quantitativos de serviços, conforme o Quadro 21, foram multiplicados por suas respectivas composições de serviços.

Quadro 21 - Identificação dos Indicadores da Equação de Prazo Ótimo - Itens Eq’t e C

\begin{tabular}{|l|c|c|c|c|}
\cline { 3 - 5 } \multicolumn{2}{l}{} & \multicolumn{2}{c}{ Dist. Média } & \multicolumn{2}{c|}{$\mathbf{K m}$} \\
\hline Descrição & Und & HH Trab. & Qte & R\$/Km \\
\hline Lancha ambulância & H & 1.799 & 10,23 & 12,68 \\
\hline $\begin{array}{l}\text { Caminhão basculante 14,0m3 - 20 Ton (279 } \\
\text { KW) }\end{array}$ & H & 61.189 & 347,67 & 0,69 \\
\hline Caminhão betoneira & H & 3.688 & 20,96 & 0,69 \\
\hline $\begin{array}{l}\text { Cavalo mecânico com carreta dolly para o } \\
\text { transporte de vigas }\end{array}$ & H & 2.179 & 12,38 & 0,69 \\
\hline Caminhão guindauto 6 Ton & H & 4.063 & 23,09 & 0,85 \\
\hline Caminhão tanque d'água 18.000 L & H & 7.062 & 40,13 & 0,69 \\
\hline Carregadeira com pneus - 3,10 m3 (127Kw) & H & 579 & 3,29 & 13,13 \\
\hline Central dosadora para concreto cap.80m3/h & H & 484 & 2,75 & 38,36 \\
\hline $\begin{array}{l}\text { Placa vibratória 2 KW - (compactador } \\
\text { manual) }\end{array}$ & H & 1.810 & 10,29 & 0,07 \\
\hline Escavadeira hidráulica com esteiras - 35 Ton & H & 5.506 & 31,29 & 19,18 \\
\hline
\end{tabular}




\begin{tabular}{|l|c|c|c|c|}
\hline Grade aradora com discos & H & 2.950 & 16,76 & 0,34 \\
\hline Grupo gerador diesel - 100/135 kVA (43 KW) & H & 7.280 & 41,36 & 0,34 \\
\hline Guindaste sobre rodas - 30 t < Cap >= 70 t & H & 1.278 & 7,26 & 1,17 \\
\hline Motoniveladora (93 KW) & H & 3.669 & 20,85 & 14,67 \\
\hline Retroescavadeira (57 KW) & H & 7.260 & 41,25 & 6,45 \\
\hline Rolo compactador pé de carneiro & H & 5.740 & 32,62 & 10,89 \\
\hline Rolo liso tandem & H & 205 & 1,17 & 12,03 \\
\hline Rolo de pneus & H & 211 & 1,20 & 12,03 \\
\hline Trator de pneus (77 KW) & H & 3.039 & 17,27 & 6,43 \\
\hline Trator de esteiras - CAT - D6 & H & 481 & 2,73 & 20,21 \\
\hline Mobilização de equipamento (média) & & $\mathbf{1 2 0 . 4 7 9}$ & $\mathbf{6 8 5}$ & $\mathbf{2 . 0 4 9}$ \\
\hline
\end{tabular}

Além das quantidades de horas de equipamentos, foi possível obter o quantitativo total de equipamentos a ser mobilizados caso a obra fosse executada em um único mês, neste caso, foi gerado o quantitativo de aproximadamente 685 equipamentos. Tal fator foi obtido pela divisão das 120.479 horas por um período médio de trabalho de equipamento de 176 horas em um mês.

O valor médio da mobilização dos equipamentos caso a obra fosse executada em um mês foi determinado pela multiplicação dos quantitativos de equipamentos para um mês de obra, pela distância média de mobilização e desmobilização, que, neste caso específico, foi adotada em $600 \mathrm{Km}$. Ao final, o valor médio de mobilização por equipamento chega a um total aproximado de $R \$ 2.049$, conforme o Quadro 21.

O Quadro 22 aborda os custos indiretos e gerenciais mensais.

Quadro 22 - Identificação dos Indicadores da Equação de Prazo Ótimo - Item C't

\begin{tabular}{|l|l|l|l|}
\hline Item & Descrição & Determinação & Resultado Exemplo \\
\hline Cl't & $\begin{array}{l}\text { Custo indireto do efetivo } \\
\text { adicionado aos gastos } \\
\text { gerenciais mensais }\end{array}$ & $\begin{array}{l}\text { A determinação deste fator } \\
\text { envolveu a determinação do } \\
\text { organograma e do efetivo } \\
\text { indireto médio mensal da obra, } \\
\text { além da determinação dos } \\
\text { custos gerenciais médios } \\
\text { mensais }\end{array}$ & $\begin{array}{l}\mathrm{R} \$ 681.662 \text { de custos } \\
\text { indiretos médios mensais, } \\
\text { sendo } \mathrm{R} \$ 552.453 \\
\text { referentes aos salários de } \\
\text { equipe e } \mathrm{R} \$ 129.209 \\
\text { referentes aos custos de } \\
\text { manutenção de canteiro }\end{array}$ \\
\hline
\end{tabular}

Para o cálculo dos custos indiretos, usou-se o histograma de mão de obra contendo todo o efetivo indireto composto por engenheiros, técnicos, auxiliares, estagiários e aprendizes. Uma vez feito o histograma deste efetivo, é possível calcular os valores médios mensais. Desta forma, chegou-se a um efetivo médio mensal de 88 funcionários com um custo médio de $R \$ 552.453$ mensais, considerando os encargos sociais devidos, conforme disposto no Quadro 23. 
Quadro 23 - Identificação dos custos do efetivo indireto mensal médio

\begin{tabular}{|l|c|c|}
\hline \multicolumn{1}{|c|}{ Indireto mensal médio } & Qtde & Valor (R\$) \\
\hline Engenharia & 13 & 206.261 \\
\hline Técnicos e auxiliares & 71 & 341.520 \\
\hline Estagiários e aprendizes & 4 & 4.671 \\
\hline Total administração da obra & $\mathbf{8 8}$ & $\mathbf{5 5 2 . 4 5 3}$ \\
\hline
\end{tabular}

A partir do Quadro 24, é possível obter um valor médio para os custos indiretos mensais decorrentes de despesas de canteiro, contas de consumo e verbas mensais para os custos de apoio. Ao final, chega-se a um custo aproximado mensal de $R \$ 129.209$.

Quadro 24 - Identificação das despesas indiretas médias de canteiro e apoio

\begin{tabular}{|c|l|c|}
\hline Item & Descrição & Valor (R\$) \\
\hline 1 & Aluguel de terreno em canteiro & 4.102 \\
\hline 2 & Custos de mobilidade & 4.932 \\
\hline 3 & Controle tecnológico e ensaios de materiais & 23.598 \\
\hline 4 & Viagens de retorno à base e serviço & 8.740 \\
\hline 5 & Contêineres - vestiário, almoxarifado, escritório & 1.854 \\
\hline 6 & Sanitário químico & 703 \\
\hline 7 & Vigilância & 29.764 \\
\hline 8 & Advogados & 9.850 \\
\hline 9 & Custos de alojamentos & 4.435 \\
\hline 10 & Relatórios fotográficos & 1.420 \\
\hline 11 & Consultores & 9.800 \\
\hline 12 & Assinaturas, correios & 290 \\
\hline 13 & Transportes, táxis & 493 \\
\hline 14 & Cópias & 298 \\
\hline 15 & Sindicatos & 1.345 \\
\hline 16 & Consumo mensal - energia elétrica & 18.320 \\
\hline 17 & Consumo mensal - água e esgoto & 990 \\
\hline 18 & Despesas com telefone fixo & 490 \\
\hline 19 & Despesas com celular & \\
\hline 20 & Despesas internas com coleta de lixo & \\
\hline & & \\
\hline
\end{tabular}




\begin{tabular}{|c|l|c|}
\hline 21 & Material de escritório & 490 \\
\hline 22 & Materiais de consumos diversos & 490 \\
\hline 23 & Equipamentos de segurança - indiretos & 2.246 \\
\hline \multicolumn{2}{r|}{ Total } & 129.209 \\
\hline
\end{tabular}

O Quadro 25 aborda o cálculo dos custos das rescisões através do Item A.

Quadro 25 - Identificação dos Indicadores da Equação de Prazo Ótimo - Item A

\begin{tabular}{|c|c|c|c|}
\hline Item & Descrição & Determinação & Resultado \\
\hline A & Custo Rescisões & $\begin{array}{l}\text { A determinação dos custos das } \\
\text { rescisões trabalhistas envolveu } \\
\text { a aplicação e análise de } \\
\text { parâmetros setoriais e de } \\
\text { legislação que contemplam os } \\
\text { passivos que ocorrem durante a } \\
\text { rescisão dos funcionários. } \\
\text { Fatores como aviso prévio, } \\
\text { aviso prévio indenizado, férias, } \\
\text { 13o proporcional, multas de } \\
\text { FGTS, entre outros, devem ser } \\
\text { considerados }\end{array}$ & $\begin{array}{l}\text { Índice } 1,27 \text {, ou seja, para } \\
\text { cada funcionário } \\
\text { contratado que será } \\
\text { demitido no futuro, } 1,27 \\
\text { salário adicional deverá } \\
\text { ser pago }\end{array}$ \\
\hline
\end{tabular}

Para o cálculo dos custos das rescisões trabalhistas, utilizou-se o Quadro 26, no qual diversos fatores foram ponderados conforme a legislação vigente. Dentre os fatores estão FGTS - Fundo de Garantia do Tempo de Serviço, indenizações por demissão e férias e $13^{\circ}$ proporcionais às indenizações. Neste caso, chega-se a um fator de 1,27, o que significa que, ao final do projeto, em média, todo funcionário receberá 1,27 salário a mais que a sua média salarial, decorrente de encargos rescisórios.

Ressalta-se que neste parâmetro foram considerados apenas indicadores que refletem encargos que gerariam custos adicionais no caso da variabilidade do prazo do projeto. Fatores como, por exemplo, a multa sobre o FGTS não entra nessa conta, pois, em qualquer circunstância, os valores pagos seriam os mesmos porque a envoltória financeira é a mesma. Já os encargos de aviso prévio, não. Eles dependem do quantitativo do efetivo que foi contratado para o projeto, e cada funcionário, ao final de seu período de trabalho, receberá tal verba indenizatória.

Outro ponto importante para salientar é a questão da temporalidade dos projetos. Como os projetos são temporais, foi considerado que todos os funcionários diretos serão demitidos no seu término, fato que gera todos esses custos indenizatórios abordados.

Para o cálculo completo do Fator $A$, somaram-se os fatores abordados. Como o salário médio do efetivo foi determinado durante o cálculo do item M’t, e é de $R \$$ 
1.327, o valor rescisório médio devido a cada funcionário adicional contratado seria de $A$ x Salário Médio = 1,27 x $1.327=R \$ 1.685$ por funcionário.

Quadro 26 - Identificação do fator de rescisão (A)

\begin{tabular}{|l|c|}
\hline Item & Fator \\
\hline Aviso prévio indenizado & 1,00 \\
\hline Férias sobre aviso & 0,11 \\
\hline FGTS sobre aviso & 0,08 \\
\hline 13osobre aviso & 0,08 \\
\hline Fator A & $\mathbf{1 , 2 7}$ \\
\hline
\end{tabular}

Quadro 27 - Identificação dos Indicadores da Equação de Prazo Ótimo - Item B

\begin{tabular}{|l|l|l|l|}
\hline Item & Descrição & Determinação & Resultado \\
\hline B & Redução de Produtividade & $\begin{array}{l}\text { Deve ser determinada uma } \\
\text { constante fixa que seja } \\
\text { inversamente variável ao prazo } \\
\text { e que determine a redução da } \\
\text { produtividade em decorrência } \\
\text { das reduções de prazo do } \\
\text { projeto. }\end{array}$ & $\begin{array}{l}\text { Para a utilização deste } \\
\text { exemplo prático, o Fator B } \\
\text { foi considerado com uma } \\
\text { perda máxima de 6,5\%, } \\
\text { variando inversamente ao } \\
\text { prazo. }\end{array}$ \\
\hline
\end{tabular}

O Gráfico 13 mostra a evolução do Parâmetro B.

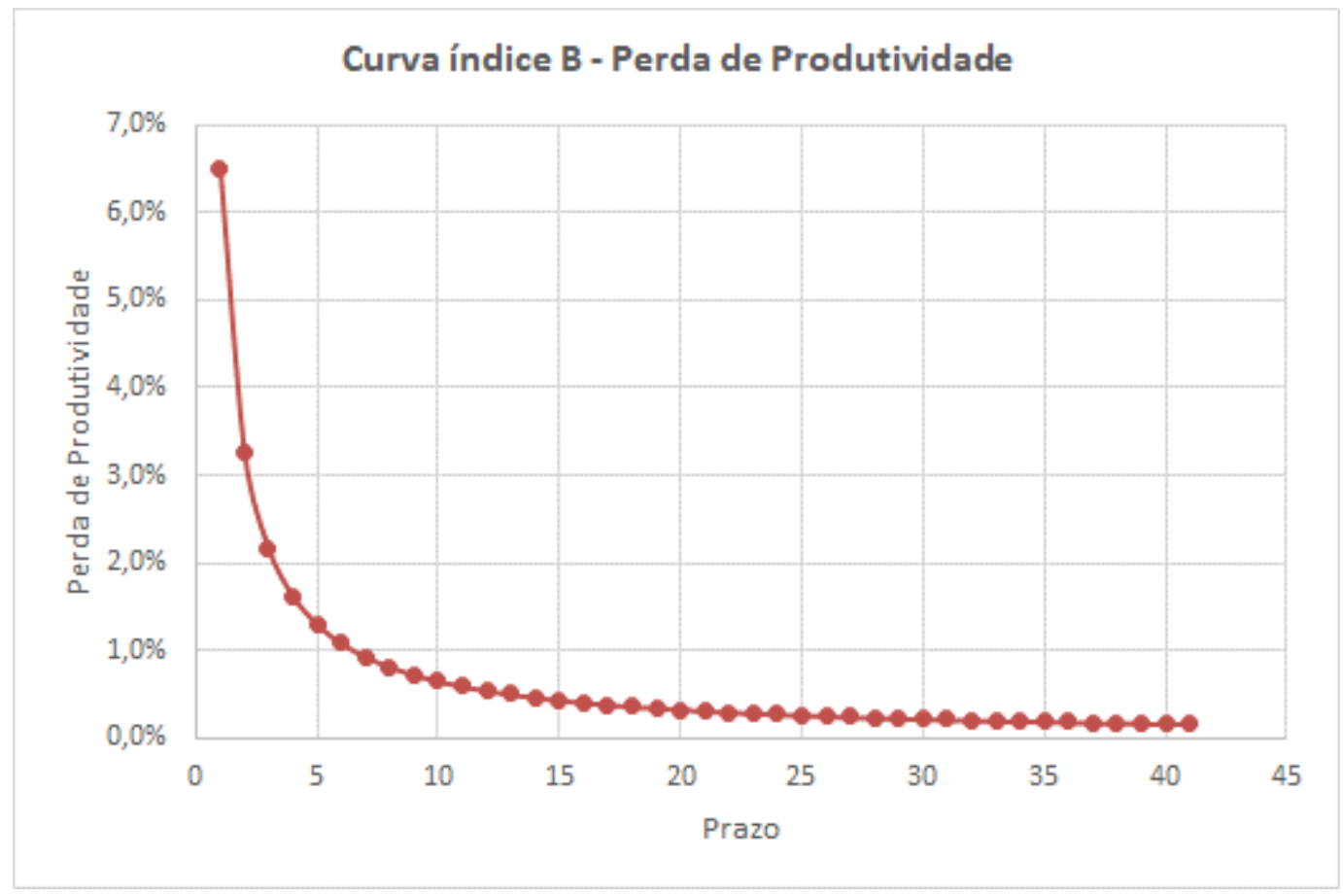

Gráfico 13 - Curva de Perda de produtividade em função do prazo do projeto 
Quadro 28 - Identificação dos Indicadores da Equação de Prazo Ótimo - Item D

\begin{tabular}{|c|c|c|c|}
\hline Item & Descrição & Determinação & Resultado \\
\hline D & Custo Canteiro de Obras & $\begin{array}{l}\text { A determinação dos custos dos } \\
\text { canteiros de obras e instalações } \\
\text { foi feita conforme cotações de } \\
\text { preços para a implantação do } \\
\text { uso do histórico existente na } \\
\text { empresa e por estimativas } \\
\text { existentes em revistas técnicas } \\
\text { e especializadas. }\end{array}$ & $\begin{array}{l}\mathrm{R} \$ 677 \text { por funcionário, } \\
\text { com o aumento do } \\
\text { número de funcionários } \\
\text { no projeto devido à } \\
\text { redução de prazos, as } \\
\text { estruturas de canteiro } \\
\text { devem aumentar, desta } \\
\text { forma, uma média de } \\
\text { acréscimo de custo por } \\
\text { funcionário deve ser } \\
\text { estabelecida. }\end{array}$ \\
\hline
\end{tabular}

Quadro 29 - Identificação do item D - custos variáveis de canteiro

\begin{tabular}{|c|c|c|}
\hline Item & V. Fixo (R\$) & V. Variável (R\$/Efetivo) \\
\hline Canteiro - Obras & 46.200 & 623 \\
\hline Canteiro - Almoxarifado & 11.088 & 44 \\
\hline Canteiro - Ind. & 5.600 & 10 \\
\hline \multicolumn{2}{c}{ Total } & 667 \\
\hline
\end{tabular}

Quadro 30 - Identificação dos Indicadores da Equação de Prazo Ótimo - Item E

\begin{tabular}{|c|c|c|c|}
\hline Item & Descrição & Determinação & Resultado \\
\hline$E$ & Custos QSMS, treinamentos & $\begin{array}{l}\text { A determinação dos custos de } \\
\text { treinamentos de QSMS foi feita } \\
\text { através da estimativa das horas } \\
\text { médias expendidas durante os } \\
\text { treinamentos necessários de } \\
\text { QSMS da empresa, integrações } \\
\text { e atividades complementares. A } \\
\text { partir da determinação do tempo } \\
\text { médio expendido para tais } \\
\text { atividades, multiplicou-se tal } \\
\text { valor pelo valor médio horário } \\
\text { do funcionário. }\end{array}$ & $\begin{array}{l}\mathrm{R} \$ 46 \text { é o custo de } \\
\text { treinamentos que cada } \\
\text { funcionário tem ao entrar } \\
\text { no projeto devido às } \\
\text { integrações, aos } \\
\text { treinamentos de } \\
\text { qualidade, entre outros. } \\
\text { Neste caso, foi } \\
\text { considerada uma média } \\
\text { mensal de treinamento de } \\
4 \text { horas por funcionário. }\end{array}$ \\
\hline
\end{tabular}

Quadro 31 - Identificação dos custos médios de treinamento por funcionário

\begin{tabular}{|l|c|c|}
\hline Item & Horas & Valor (R\$) \\
\hline Treinamentos & 4,0 & 46 \\
\hline
\end{tabular}


Quadro 32 - Identificação dos Indicadores da Equação de Prazo Ótimo - Item F

\begin{tabular}{|c|c|c|c|}
\hline Item & Descrição & Determinação & Resultado \\
\hline $\mathrm{F}$ & $\begin{array}{l}\text { Custos EPI + Exames } \\
\text { médicos }\end{array}$ & $\begin{array}{l}\text { A determinação dos custos de } \\
\text { ferramentas adicionais e dos } \\
\text { EPIs que a empresa fornece } \\
\text { aos funcionários também deve } \\
\text { ser realizada a partir de } \\
\text { cotações de preços e média de } \\
\text { gastos estimados. Estes } \\
\text { fatores se caracterizam por ter } \\
\text { uma quantidade fixa durante o } \\
\text { início e o término do projeto } \\
\text { (exames admissionais e } \\
\text { demissionais) e também por } \\
\text { substituição ou } \\
\text { acompanhamento (exames } \\
\text { periódicos). }\end{array}$ & $\begin{array}{l}\mathrm{R} \$ 145 \text { fixos (Exames) + R } \$ 241 \\
\text { fixos (EPIs) + R } \$ 7,5 \text { por mês por } \\
\text { funcionário (Exames) + R } \$ 59 \text { por } \\
\text { mês por funcionário (EPIs). Os } R \$ \\
145 \text { e } R \$ 241 \text { se referem aos } \\
\text { custos de exames admissionais e } \\
\text { demissionais que cada funcionário } \\
\text { deverá fazer, além da soma dos } \\
\text { uniformes e EPIs que cada } \\
\text { funcionário recebe. Os } R \$ 7,5 \text { e } \\
R \$ 59 \text { são referentes aos custos } \\
\text { de trocas e substituição de } \\
\text { uniformes e EPIs, além dos custos } \\
\text { médios de exames periódicos. }\end{array}$ \\
\hline
\end{tabular}

Quadro 33 - Identificação dos custos fixos e variáveis do Item F

\begin{tabular}{|l|c|c|}
\hline Item & Custo Fixo (R\$) & $\begin{array}{c}\text { Custo Variável } \\
\text { (R\$/Prazo/Funcionário) }\end{array}$ \\
\hline Exames médicos & 145 & 7,5 \\
\hline EPI & 241 & 59 \\
\hline
\end{tabular}

Quadro 34 - Identificação dos Indicadores da Equação de Prazo Ótimo - Item G

\begin{tabular}{|c|c|c|c|}
\hline Item & Descrição & Determinação & Resultado \\
\hline G & $\begin{array}{l}\text { Economia de Escala - } \\
\text { Suprimentos }\end{array}$ & $\begin{array}{l}\text { A determinação desta constante } \\
\text { inversamente proporcional ao } \\
\text { prazo implica em estimar algum } \\
\text { desconto no valor de todos os } \\
\text { materiais que serão adquiridos } \\
\text { no projeto. A compra de um } \\
\text { quantitativo expressivo em um } \\
\text { prazo menor gera economia de } \\
\text { escala e proporciona maiores } \\
\text { descontos nas negociações. }\end{array}$ & $\begin{array}{l}5,2 \% \text { de economia no } \\
\text { valor total dos materiais } \\
\text { do projeto em função da } \\
\text { economia gerada ao se } \\
\text { comprar os materiais em } \\
\text { ordens de compras mais } \\
\text { expressivas. }\end{array}$ \\
\hline
\end{tabular}

O Gráfico 14 mostra a evolução do Parâmetro G. 


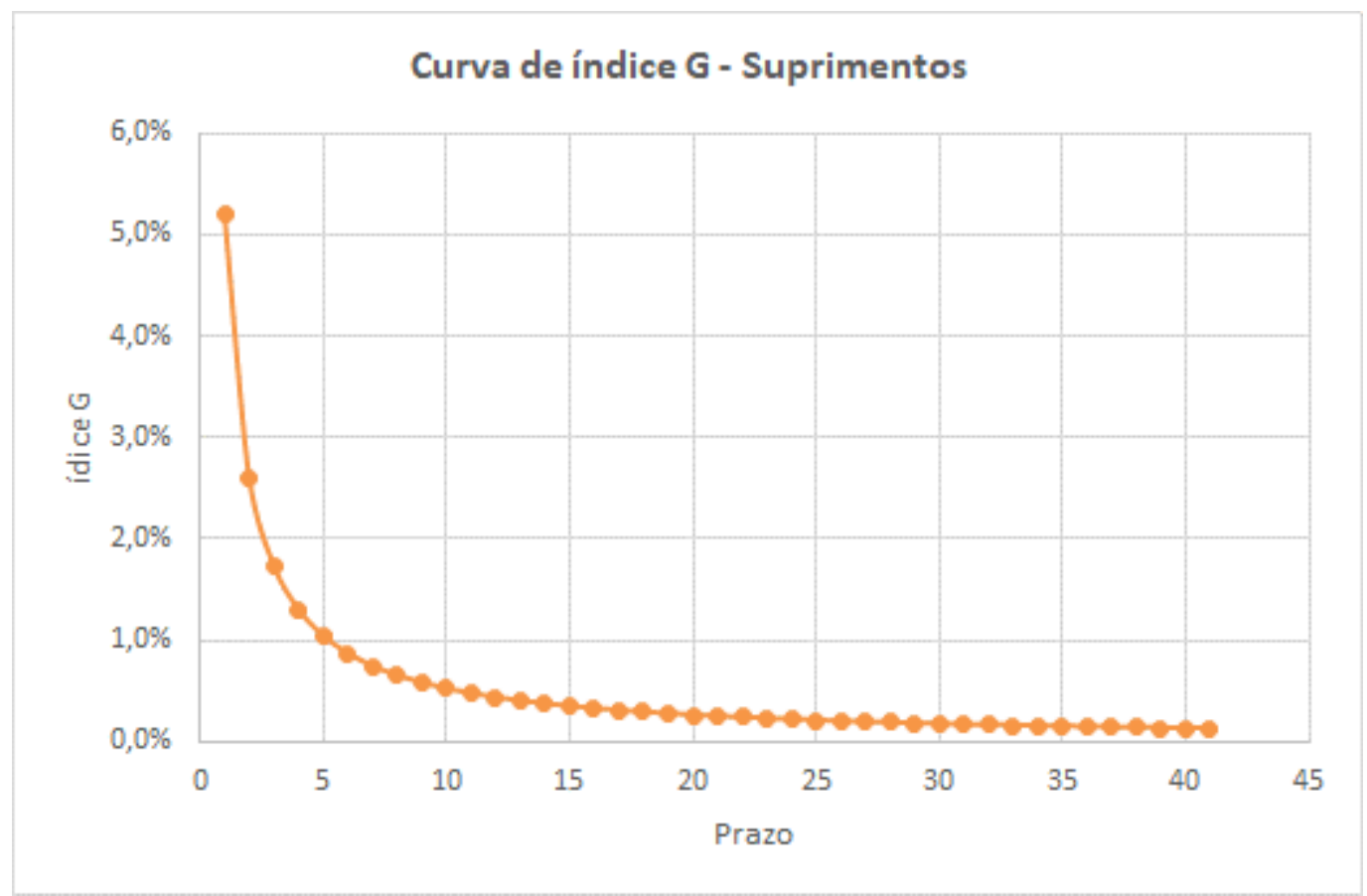

Gráfico 14 - Curva de perda em função do prazo do projeto

Quadro 35 - Identificação dos Indicadores da Equação de Prazo Ótimo - Item H

\begin{tabular}{|l|l|l|l|}
\hline Item & Descrição & Determinação & Resultado \\
\hline $\mathrm{H}$ & Aumento de horas extras & $\begin{array}{l}\text { Constante fixa inversamente } \\
\text { proporcional ao prazo do } \\
\text { projeto. Ao se reduzir o prazo } \\
\text { de um projeto, além de ser } \\
\text { gerados recursos de MO } \\
\text { adicionais, há uma tendência de } \\
\text { elevação nas horas extras (que } \\
\text { são mais caras que as horas } \\
\text { normais). }\end{array}$ & $\begin{array}{l}3,5 \% \text {, valor de aumento } \\
\text { nos custos devido ao } \\
\text { aumento de horas extras } \\
\text { adicionais necessárias } \\
\text { para a redução de prazo. }\end{array}$ \\
\hline
\end{tabular}

O Gráfico 15 mostra a evolução do Parâmetro H. 


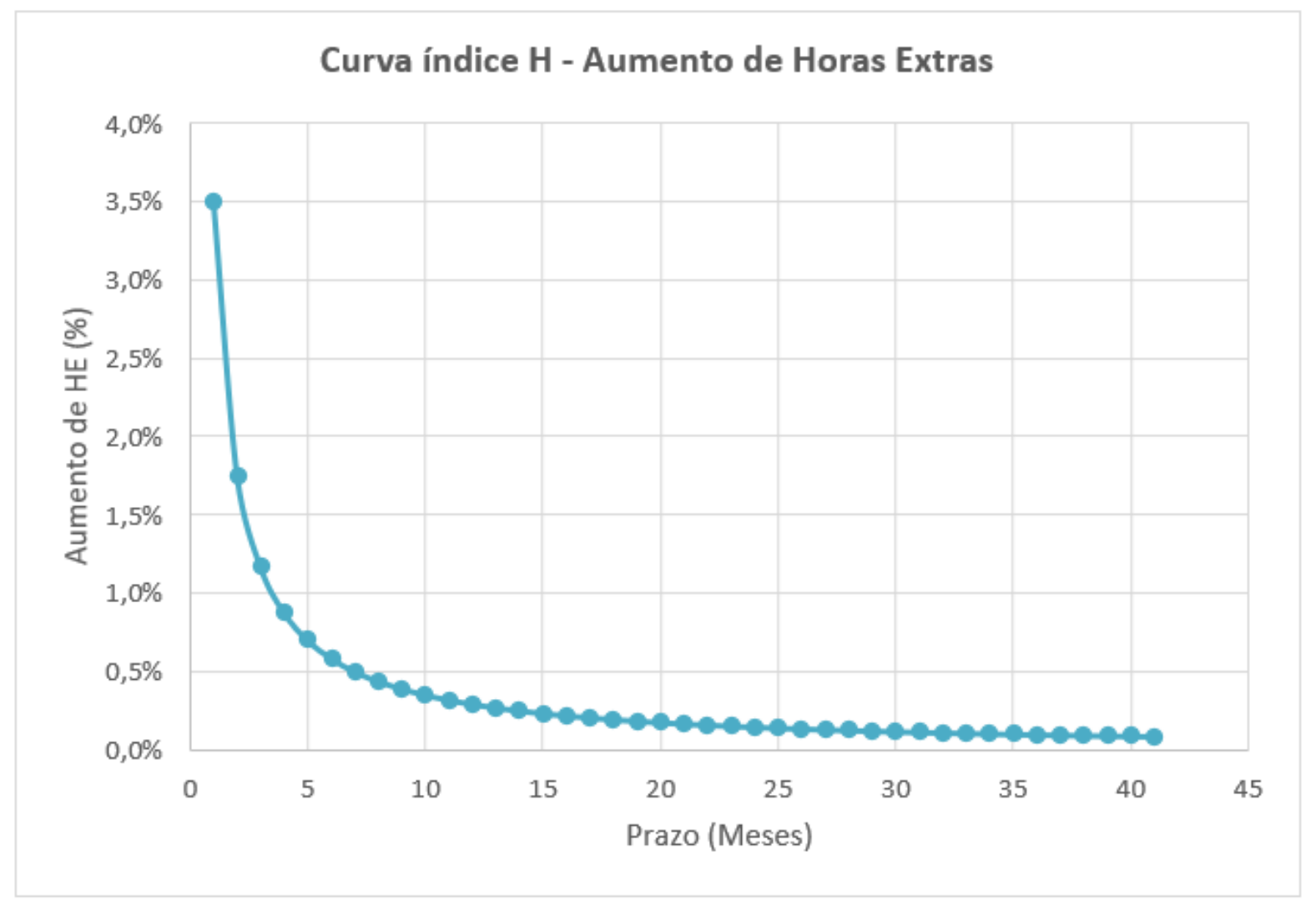

Gráfico 15 - Curva de aumento de horas extras em função do prazo

Quadro 36 - Identificação dos Indicadores da Equação de Prazo Ótimo - Item R

\begin{tabular}{|l|l|l|l|}
\hline Item & Descrição & Determinação & Resultado \\
\hline $\mathrm{R}$ & Índice de Rotatividade de MO & $\begin{array}{l}\text { A determinação do índice de } \\
\text { rotatividade de MO é obtida } \\
\text { através da experiência prévia do do } \\
\text { orçamentista e das memórias } \\
\text { existentes de projetos em obras } \\
\text { e regiões similares. }\end{array}$ & $\begin{array}{l}\text { Índice adotado igual a 1,0 } \\
\text { parajeto, por não } \\
\text { suficientes. }\end{array}$ \\
\hline
\end{tabular}

Quadro 37 - Identificação dos Indicadores da Equação de Prazo Ótimo - Item S

\begin{tabular}{|c|c|c|c|}
\hline Item & Descrição & Determinação & Resultado \\
\hline$S$ & $\begin{array}{l}\text { Percentual de MO não } \\
\text { subcontratada }\end{array}$ & $\begin{array}{l}\text { A determinação do percentual } \\
\text { de MO não subcontratada } \\
\text { envolve a expertise de o } \\
\text { orçamentista determinar o tipo } \\
\text { de obra e o percentual médio de } \\
\text { serviços especializados que } \\
\text { normalmente são } \\
\text { subcontratados. Algumas obras } \\
\text { inclusive possuem instrumentos } \\
\text { contratuais que limitam ou } \\
\text { exigem um percentual mínimo } \\
\text { de subcontratação. }\end{array}$ & $\begin{array}{l}\text { Neste caso, não foi } \\
\text { necessário o cálculo do } \\
\text { fator, pois todas as } \\
\text { composições já } \\
\text { discriminaram quais } \\
\text { serviços seriam } \\
\text { subcontratados, então nas } \\
\text { contas anteriores de MO, } \\
\text { já estavam separados } \\
\text { apenas os funcionários } \\
\text { que seriam contratados. }\end{array}$ \\
\hline
\end{tabular}


Quadro 38 - Identificação dos Indicadores da Equação de Prazo Ótimo - Item K

\begin{tabular}{|l|l|l|l|}
\hline Item & Descrição & Determinação & Resultado Exemplo \\
\hline $\mathrm{K}$ & Fator majorador de pico & $\begin{array}{l}\text { A determinação do fator } \\
\text { majorador de pico envolve a } \\
\text { aplicação de um fator de pico } \\
\text { que faz com que seja }\end{array}$ & $\begin{array}{l}\text { Índice 1,6, ou seja, no } \\
\text { pico, a maior quantidade } \\
\text { de funcionários que a } \\
\text { obra possuirá será de 1,6 } \\
\text { de funcionários possível durante } \\
\text { multiplicado pela }\end{array}$ \\
$\begin{array}{l}\text { quantidade média mensal } \\
\text { de funcionários (que pode } \\
\text { calculado utilizando-se da } \\
\text { particularidade de as obras } \\
\text { seguirem um padrão de avanço } \\
\text { muito semelhante à Curva S. O } \\
\text { detalhamento de como calcular }\end{array}$ & $\begin{array}{l}\text { ser determinada por M't } \\
\text { dividido pelo prazo da } \\
\text { obra). Fator calculado de } \\
\text { está descrito no ltem 2.2 }\end{array}$ & $\begin{array}{l}\text { explorada anteriormente, } \\
\text { de acordo com os } \\
\text { parâmetros do projeto. }\end{array}$ \\
\hline
\end{tabular}

Quadro 39 - Identificação do fator de pico K

PICO - DIST. NORMAL

Fator K - Pico

No Quadro 40, pode-se observar um resumo dos 16 fatores da equação do prazo ótimo.

Quadro 40 - Tabela de resumo de Indicadores da Equação de Prazo Ótimo

\begin{tabular}{|l|l|c|}
\hline Item & Descrição & Valor \\
\hline M't & MO para execução da Obra em um mês & 3.469 funcionários \\
\hline Sm & Salário médio dos funcionários, produção & $\mathrm{R} \$ 1.327 /$ funcionário \\
\hline Mat'0 & Custo total dos Materiais & $\mathrm{R} \$ 43.618 .390$ \\
\hline Cl't & Custo indireto médio mensal $\$ 681.662 /$ mês \\
\hline A & Custo Rescisões & 1,27 Salário = $\mathrm{R} \$ 1.685 /$ funcionário \\
\hline $\mathrm{B}$ & Perda de Produtividade (aumento efetivo) & $6,5 \%$ de perda máxima \\
\hline $\mathrm{C}$ & Custo Mobilização Equipamentos & $\mathrm{R} \$ 2.049 /$ equipamento \\
\hline $\mathrm{D}$ & Custo Canteiro de Obras & $\mathrm{R} \$ 677 /$ funcionário \\
\hline $\mathrm{E}$ & Custos QSMS, treinamentos & $\mathrm{R} \$ 46 /$ funcionário \\
\hline $\mathrm{F}$ & Custos EPI + Exames médicos & $\mathrm{R} \$ 386 /$ funcionário + R $\$ 67 /$ mês - funcionário \\
\hline $\mathrm{G}$ & Economia de Escala - Suprimentos & $5,2 \%$ de desconto máximo \\
\hline $\mathrm{R}$ & Índice de Rotatividade de MO & 1,0 \\
\hline $\mathrm{S}$ & Percentual de MO não subcontratada & Não adotado \\
\hline $\mathrm{K}$ & Fator majorador de pico & 1,6 \\
\hline $\mathrm{H}$ & Aumento de Horas Extras & $3,5 \%$ máximo \\
\hline
\end{tabular}




\subsubsection{DETERMINAÇÃO DO PRAZO ÓTIMO TEÓRICO}

A partir da determinação dos dezesseis parâmetros do item anterior, é realizado o cálculo da curva dos custos variáveis e, para a determinação do prazo ótimo, apenas fazendo a substituição dos parâmetros nas Equações (16) e (18).

$$
\begin{aligned}
& C T A_{t}=\left(K R S \frac{M^{\prime}{ }_{t}}{t} S_{m}(A)+M^{\prime}{ }_{t} S_{m} \frac{(B+H)}{t}+\frac{E q^{\prime}}{t}(C)\right. \\
& \left.+K R S \frac{M^{\prime}{ }_{t}}{t}(D+E+F)-M a t^{\prime}{ }_{0} \frac{(G)}{t}+C I^{\prime}{ }_{t} \times t\right) \\
& t_{\text {ótimo }}=\sqrt{\frac{K R S M^{\prime}{ }_{t}\left(A S_{m}+D+E+F\right)+M^{\prime}{ }_{t} S_{m}(B+H)+E q^{\prime}{ }_{t}(C)-M a t^{\prime}{ }_{0}(G)}{C I^{\prime}{ }_{t}}} \\
& t_{\text {ótimo }}=5,19 \text { meses }
\end{aligned}
$$

\begin{tabular}{|c|c|c|c|c|c|c|c|c|c|c|c|c|}
\hline \multicolumn{13}{|c|}{ RESUMO ORÇAMENTÁRI } \\
\hline Prazo & 1,00 & 2,00 & 3,00 & 4,00 & 5,00 & 6,00 & 7,00 & 8,00 & 9,00 & 10,00 & 11,00 & 12,00 \\
\hline Custos Diretos & $18.330 .043,45$ & $9.352 .338,51$ & $6.359 .770,20$ & $4.863 .486,04$ & $3.965 .715,55$ & $3.367 .201,88$ & $2.939 .692,12$ & $2.619 .059,81$ & $2.369 .679,11$ & $2.170 .174,56$ & $2.006 .943,56$ & $1.870 .917,73$ \\
\hline Mão de Obra & $16.927 .160,67$ & $8.650 .897,12$ & $5.892 .142,60$ & $4.512 .765,35$ & $3.685 .138,99$ & $3.133 .388,09$ & $2.739 .280,30$ & $2.443 .699,46$ & $2.213 .803,25$ & $2.029 .886,28$ & $1.879 .408,76$ & $1.754 .010,83$ \\
\hline Materiais & $(2.268 .156,28)$ & $(1.134 .078,14)$ & $(756.052,09)$ & $(567.039,07)$ & $(453.631,26)$ & $(378.026,05)$ & $(324.022,33)$ & $(283.519,54)$ & $(252.017,36)$ & $(226.815,63)$ & $(206.196,03)$ & $(189.013,02)$ \\
\hline Equipamento & $1.402 .882,78$ & $701.441,39$ & $467.627,59$ & $350.720,69$ & $280.576,56$ & $233.813,80$ & $200.411,83$ & $175.360,35$ & $155.875,86$ & $140.288,28$ & $127.534,80$ & $116.906,90$ \\
\hline Custos Indiretos & $681.662,92$ & $1.363 .325,84$ & $2.044 .988,76$ & $2.726 .651,68$ & $3.408 .314,59$ & $4.089 .977,51$ & $4.771 .640,43$ & $5.453 .303,35$ & $6.134 .966,27$ & $6.816 .629,19$ & $7.498 .292,11$ & $8.179 .955,03$ \\
\hline Custos Totais & 19.011.706,36 & $10.715 .664,35$ & $8.404 .758,95$ & $7.590 .137,72$ & $7.374 .030,14$ & 7.457.179,40 & 7.711.332,56 & $8.072 .363,16$ & $8.504 .645,38$ & $8.986 .803,75$ & $9.505 .235,67$ & $10.050 .872,75$ \\
\hline Prazo & 13,00 & 14,00 & 15,00 & 16,00 & 17,00 & 18,00 & 19,00 & 20,00 & 21,00 & 22,00 & 23,00 & 24,00 \\
\hline Custos Diretos & $1.755 .818,95$ & $1.657 .162,85$ & $1.571 .660,90$ & $1.496 .846,69$ & $1.430 .834,15$ & $1.372 .156,34$ & $1.319 .655,14$ & $1.272 .404,07$ & $1.229 .653,09$ & $1.190 .788,57$ & $1.155 .303,57$ & $1.122 .775,65$ \\
\hline Mão de Obra & $1.647 .904,89$ & 1.556.956,94 & $1.478 .135,38$ & $1.409 .166,52$ & 1.348.311,64 & $1.294 .218,41$ & $1.245 .819,21$ & $1.202 .259,93$ & $1.162 .849,15$ & 1.127.021,17 & $1.094 .308,66$ & $1.064 .322,20$ \\
\hline Materiais & $(174.473,56)$ & $(162.011,16)$ & $(151.210,42)$ & $(141.759,77)$ & $(133.420,96)$ & $(126.008,68)$ & $(119.376,65)$ & $(113.407,81)$ & $(108.007,44)$ & $(103.098,01)$ & $(98.615,49)$ & $(94.506,51)$ \\
\hline Equipamento & $107.914,06$ & $100.205,91$ & $93.525,52$ & $87.680,17$ & $82.522,52$ & $77.937,93$ & $73.835,94$ & $70.144,14$ & $66.803,94$ & $63.767,40$ & $60.994,90$ & $58.453,45$ \\
\hline Custos Indiretos & $8.861 .617,94$ & $9.543 .280,86$ & $10.224 .943,78$ & $10.906 .606,70$ & 11.588.269,62 & $12.269 .932,54$ & $12.951 .595,46$ & $13.633 .258,38$ & 14.314.921,29 & $14.996 .584,21$ & $15.678 .247,13$ & 16.359.910,05 \\
\hline Custos Totais & $10.617 .436,89$ & $11.200 .443,71$ & $11.796 .604,68$ & $12.403 .453,39$ & $13.019 .103,77$ & $13.642 .088,88$ & $14.271 .250,60$ & $14.905 .662,44$ & $15.544 .574,38$ & $16.187 .372,78$ & $16.833 .550,70$ & $17.482 .685,70$ \\
\hline Prazo & 25,00 & 26,00 & 27,00 & 28,00 & 29,00 & 30,00 & 31,00 & 32,00 & 33,00 & 34,00 & 35,00 & 36,00 \\
\hline Custos Diretos & $1.092 .849,97$ & $1.065 .226,26$ & $1.039 .648,75$ & $1.015 .898,21$ & $993.785,64$ & $973.147,23$ & $953.840,34$ & $935.740,13$ & $918.736,90$ & $902.733,86$ & $887.645,28$ & $873.394,96$ \\
\hline Mão de Obra & $1.036 .734,66$ & 1.011.269,23 & $987.690,13$ & $965.795,25$ & $945.410,37$ & $926.384,47$ & $908.586,06$ & $891.900,04$ & $876.225,30$ & $861.472,60$ & $847.562,92$ & $834.425,99$ \\
\hline Materiais & $(90.726,25)$ & $(87.236,78)$ & $(84.005,79)$ & $(81.005,58)$ & $(78.212,29)$ & $(75.605,21)$ & $(73.166,33)$ & $(70.879,88)$ & $(68.732,01)$ & $(66.710,48)$ & $(64.804,47)$ & $(63.004,34)$ \\
\hline Equipamento & $56.115,31$ & $53.957,03$ & $51.958,62$ & $50.102,96$ & $48.375,27$ & $46.762,76$ & $45.254,28$ & $43.840,09$ & $42.511,60$ & $41.261,26$ & $40.082,37$ & $38.968,97$ \\
\hline Custos Indiretos & $17.041 .572,97$ & $17.723 .235,89$ & $18.404 .898,81$ & $19.086 .561,73$ & $19.768 .224,65$ & $20.449 .887,56$ & $21.131 .550,48$ & $21.813 .213,40$ & $22.494 .876,32$ & $23.176 .539,24$ & $23.858 .202,16$ & $24.539 .865,08$ \\
\hline Custos Totais & 18.134.422,94 & $18.788 .462,15$ & $19.444 .547,56$ & 20.102.459,94 & $20.762 .010,28$ & $21.423 .034,80$ & 22.085.390,82 & 22.748.953,53 & 23.413.613,22 & 24.079.273,10 & $24.745 .847,44$ & 25.413.260,03 \\
\hline Prazo & 37,00 & 38,00 & 39,00 & 40,00 & 41,00 & 42,00 & 43,00 & 44,00 & 45,00 & 46,00 & 47,00 & 48,00 \\
\hline Custos Diretos & $859.914,92$ & $847.144,36$ & $835.028,70$ & $823.518,82$ & $812.570,40$ & $802.143,33$ & $792.201,24$ & $782.711,07$ & $773.642,68$ & $764.968,57$ & $756.663,57$ & $748.704,61$ \\
\hline Mão de Obra & $821.999,17$ & $810.226,39$ & $799.057,34$ & $788.446,75$ & $778.353,74$ & $768.741,36$ & $759.576,06$ & $750.827,37$ & $742.467,51$ & $734.471,12$ & $726.815,00$ & $719.477,89$ \\
\hline Materiais & $(61.301,52)$ & $(59.688,32)$ & $(58.157,85)$ & $(56.703,91)$ & $(55.320,88)$ & $(54.003,72)$ & $(52.747,82)$ & $(51.549,01)$ & $(50.403,47)$ & $(49.307,75)$ & $(48.258,64)$ & $(47.253,26)$ \\
\hline Equipamento & $37.915,75$ & $36.917,97$ & $35.971,35$ & $35.072,07$ & $34.216,65$ & $33.401,97$ & $32.625,18$ & $31.883,70$ & $31.175,17$ & $30.497,45$ & $29.848,57$ & $29.226,72$ \\
\hline Custos Indiretos & $25.221 .528,00$ & 25.903.190,91 & $26.584 .853,83$ & $27.266 .516,75$ & 27.948.179,67 & 28.629.842,59 & 29.311.505,51 & 29.993.168,43 & $30.674 .831,35$ & $31.356 .494,26$ & $32.038 .157,18$ & $32.719 .820,10$ \\
\hline Custos Totais & 26.081.442,92 & $26.750 .335,27$ & $27.419 .882,53$ & $28.090 .035,57$ & $28.760 .750,07$ & 29.431.985,92 & $30.103 .706,75$ & $30.775 .879,50$ & $31.448 .474,03$ & $32.121 .462,83$ & $32.794 .820,75$ & $33.468 .524,71$ \\
\hline
\end{tabular}

Abaixo, segue a planilha de cálculo utilizada para validação de todo o modelo e elaboração dos gráficos.

Figura 16 - Planilha de Cálculo dos custos variáveis 


\subsubsection{ESTUDO DA CURVA DE CUSTOS VARIÁVEIS}

O Gráfico 16 representa a curva dos custos variáveis para o projeto estudado em função de diferentes cenários para o tempo de execução. Nesta curva, é possível observar o comportamento inversamente proporcional ao prazo dos custos diretos, o comportamento diretamente proporcional ao prazo dos custos indiretos, 0 comportamento parabólico da curva final resultante da adição dos custos diretos e indiretos e o ponto onde o prazo é ótimo para o projeto.

Analisando a curva juntamente com toda a explanação de suas características, conforme abordado no Item 3.1.1 e em seus subitens, fica perceptível, pela elevada inclinação da curva vermelha dos custos resultante, que este projeto tem alto potencial de redução de custos caso haja alteração nos prazos do projeto. Ao final, para este tipo de projeto, a resposta final de análise do item é que a análise deve ser continuada nos Itens $6^{\circ}$ e $7^{\circ}$, pois o projeto gera potenciais ganhos com a sua redução de prazo.

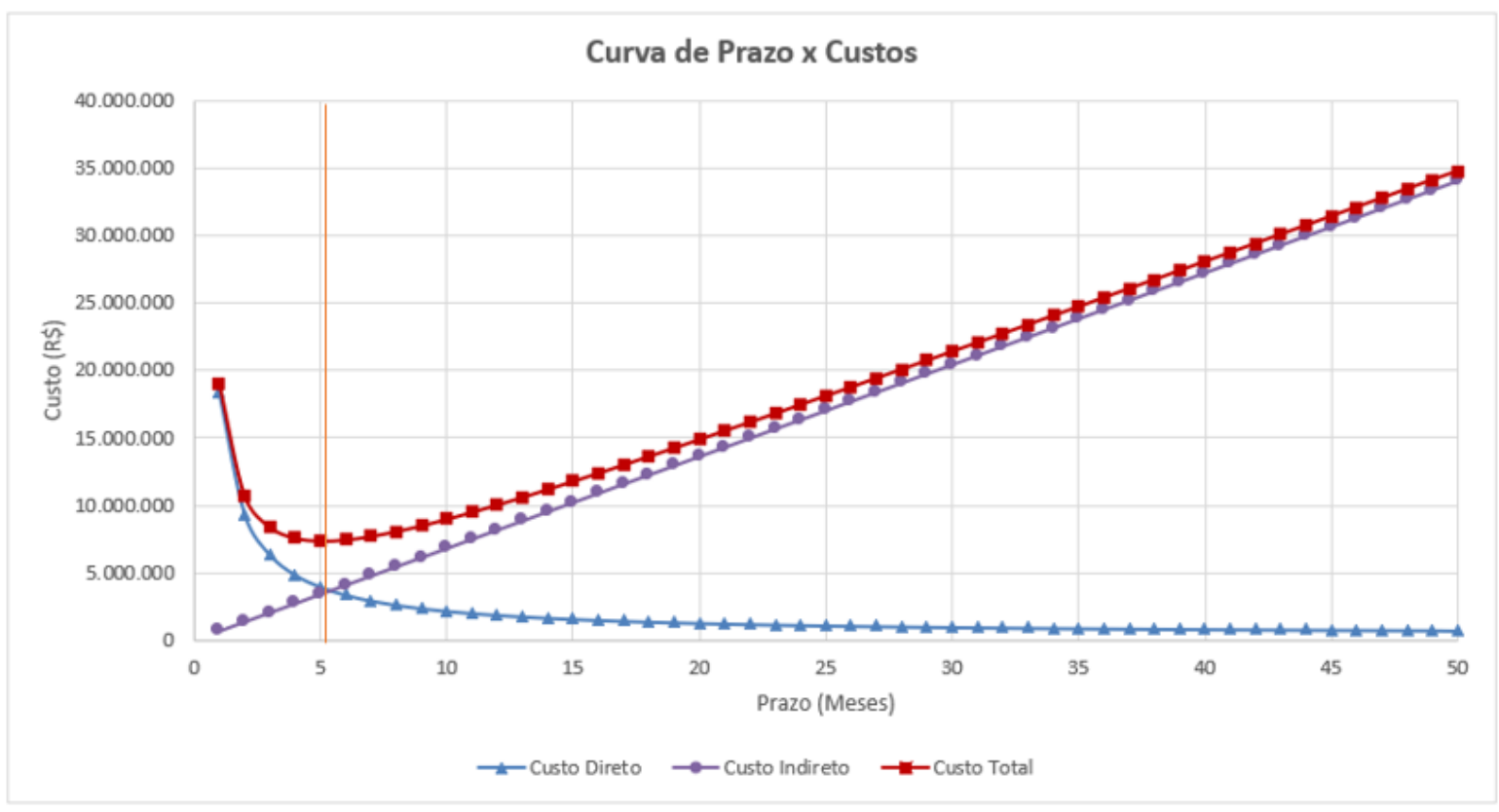

Gráfico 16 - Curva de prazo ótimo - Ponte 1,6 Km

\subsubsection{VERIFICAÇÃO SE O PRAZO ESTIMADO INICIALMENTE É MAIOR OU MENOR QUE O PRAZO ÓTIMO DETERMINADO}

Conforme abordado anteriormente, no caso da identificação de alto potencial de economia com as reduções de prazo, cabe ao orçamentista identificar se o prazo inicialmente concebido para o projeto é maior ou menor que o prazo ótimo calculado pela Equação (18) e tomar as decisões, conforme abordado no Item 3.1.4.

Em uma análise detalhada deste item, considera-se que o prazo ótimo obtido foi de 5 meses e que o prazo de edital do projeto é de 36 meses, conforme o Gráfico 17. Desta maneira, é muito válido o reestudo dos cronogramas do projeto a fim de 
encontrar o menor prazo possível até o limite do prazo ótimo em ordem de encontrar o menor custo total, conforme o próximo item.

\subsubsection{RECÁlCULO E DETERMINAÇ̃̃o DO CRONOGRAMA A PONTO-LIMITE DE ACORDO COM A DEFINIÇÃO ADOTADA NA ETAPA ANTERIOR}

Neste caso em específico, fazendo os estudos de maior redução de prazo possível, considerando maiores equipes de trabalho, e não considerando nenhuma modificação tecnológica dos serviços, apenas o aproveitamento dos seus limites máximos, o cronograma se reduziu para 26 meses, conforme o Gráfico 17. Este prazo de 26 meses é limitado devido ao sequenciamento das atividades do caminho crítico (estacas, blocos, pilares, travessas) que são limitadas, por exemplo, pelo tempo de cura do concreto. No Apêndice B, há um cronograma mostrando este sequenciamento das atividades críticas.

Desta maneira, também fica possível a identificação das zonas de projeto, conforme - Gráfico 17. Neste caso, a parte que está marcada na região azul é a área onde é possível ocorrer a redução do prazo e a consecutiva redução dos custos totais. Já a parte marcada na região rosa é a parte em que, para que houvesse a redução do prazo, seria necessária a mudança tecnológica dos sistemas empregados no projeto.

O conhecimento das zonas do projeto é extremamente importante, uma vez que os orçamentistas, detendo estas informações, além do conhecimento da região e dos valores de economia de custo na mudança do prazo, possuem disponível a informação para analisar os custos de economia de prazo versus uma possível troca de tecnologia construtiva, que normalmente acresceria os custos.

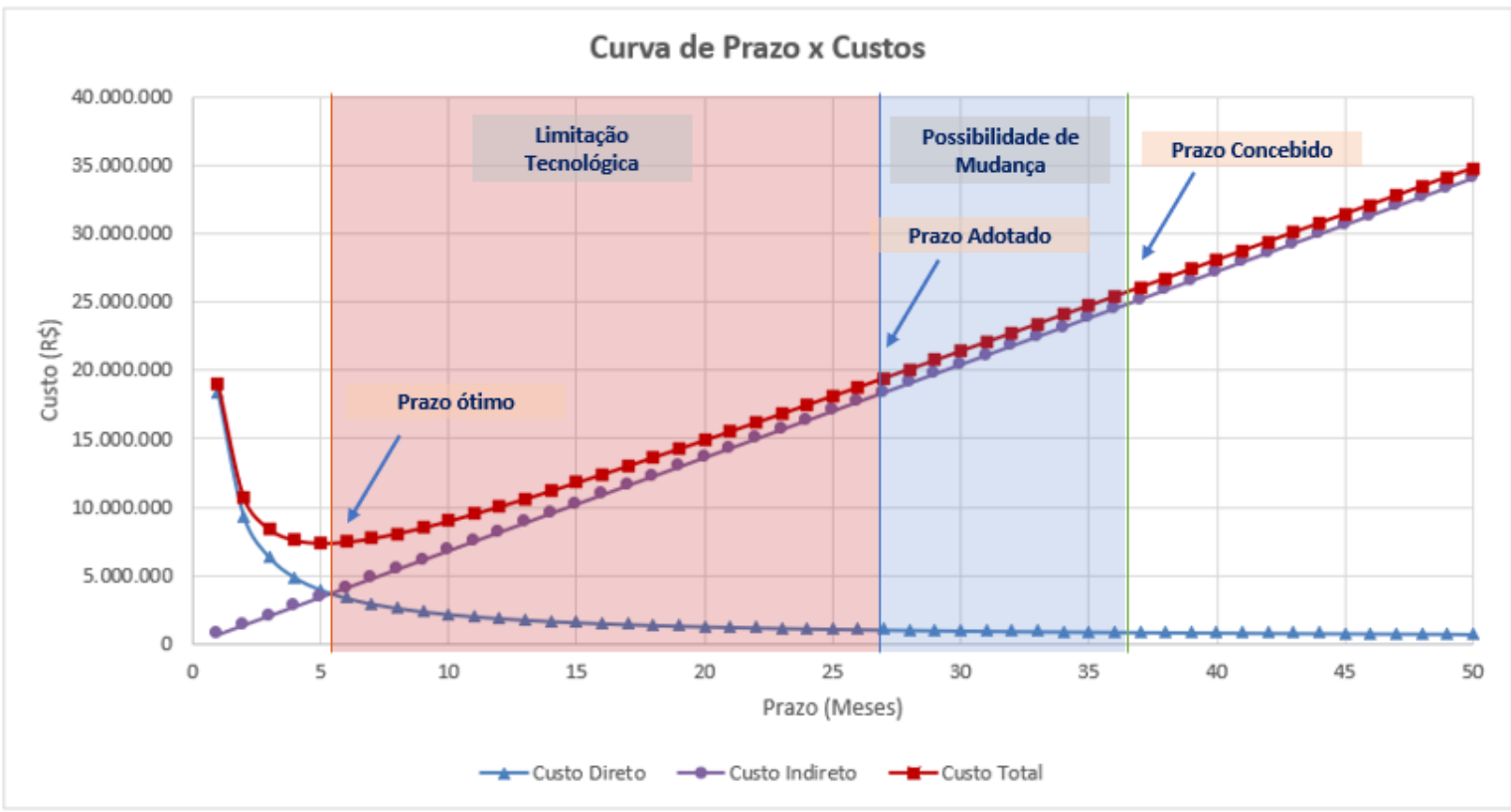

Gráfico 17 - Curva de prazo ótimo - Ponte 1,6 Km (zonas de projeto) 


\subsubsection{CÁLCULO FINAL DO POTENCIAL DE ECONOMIA UTILIZANDO PARÂMETROS DO CRONOGRAMA RECALCULADO}

Uma vez estabelecido o novo prazo que mais se aproxima do prazo ótimo préconcebido, que neste caso é de 26 meses, pode ser feito o cálculo final do potencial de economia a ser gerada pela redução de prazos. Tal valor foi determinado pelo uso da Equação (19).

$$
\begin{aligned}
\Delta C A_{t_{\text {ótimo }}}= & \left(\begin{array}{l}
K R S \frac{M^{\prime}{ }_{t}}{t} S_{m}(A)+M^{\prime}{ }_{t} S_{m} \frac{(B+H)}{t}+\frac{E q^{\prime}{ }_{t}}{t}(C) \\
+K R S \frac{M^{\prime}{ }_{t}}{t}(D+E+F)-M a t^{\prime}{ }_{0} \frac{(G)}{t}+C I^{\prime}{ }_{t} \times t
\end{array}\right) \\
& -\left(K R S \frac{M^{\prime}{ }_{t}}{t_{\text {ótimo }}} S_{m}(A)+M^{\prime}{ }_{t} S_{m} \frac{(B+H)}{t_{\text {ótimo }}}+\frac{E q^{\prime}{ }_{t}}{t_{\text {ótimo }}}(C)\right. \\
& \left.+K R S \frac{M^{\prime}{ }_{t}}{t_{\text {ótimo }}}(D+E+F)-M a t^{\prime}{ }_{0} \frac{(G)}{t_{\text {ótimo }}}+C I^{\prime}{ }_{t} \times t_{\text {ótimo }}\right)
\end{aligned}
$$

Neste caso, ao comparar os custos variáveis com o tempo, percebe-se que o projeto durando 36 meses, os custos variáveis totalizavam aproximadamente $R \$ 25 \mathrm{MM}$. Com a redução de prazo de 10 meses, o projeto ficaria com 26 meses e teria um custo variável de aproximadamente $R \$ 18 \mathrm{MM}$, gerando uma economia aproximada de $R \$ 6 \mathrm{MM}$, que representa um desconto no preço-base do edital, que é de $R \$ 150$ MM, de 4,4\%, conforme o Quadro 41.

Quadro 41 - Cálculo da economia gerada pelo método

Economia Gerada
\begin{tabular}{|l|c|}
\hline Custos variáveis - 36 meses & $\mathbf{4 , 4 \%}$ \\
\hline Custos variáveis - 26 meses & $\mathrm{R} \$ 18.413 .260,03$ \\
\hline Ganhos & $\mathbf{R} \mathbf{\$} \mathbf{6 . 6 2 4 . 7 9 7 , 8 9}$ \\
\hline
\end{tabular}

A partir dos cálculos efetuados acima, ficam perceptíveis as vantagens do uso do método para alguns tipos de projeto. Neste caso em específico, uma ordem de economia de $4,4 \%$ sobre o preço-base de um edital de obra é um valor que pode fazer com que a empresa ganhe um elevado nível competitivo nas concorrências.

Caso a obra conseguisse reduzir o seu prazo ao prazo ótimo de cinco meses, a economia gerada poderia chegar até o valor de $R \$ 18 \mathrm{MM}$, potencializando uma economia de até $12 \%$ sobre o preço-base do edital.

Quadro 42 - Cálculo da economia máxima gerada pelo método

\begin{tabular}{|l|c|}
\hline Economia Gerada Máxima & $\mathbf{1 2 , 0 \%}$ \\
\hline $\begin{array}{l}\text { Custos variáveis - } 36 \text { meses } \\
\text { Custos variáveis - } 5 \text { meses }\end{array}$ & $\mathrm{R} \$ 25.413 .260,03$ \\
$\mathrm{R} \$ 7.374 .030,14$ \\
\hline Ganhos & $\mathbf{R} \$ \mathbf{1 8 . 0 3 9 . 2 2 9 , 8 9}$ \\
\hline
\end{tabular}


A seguir, o cronograma macro do projeto, mostrando três situações distintas, prazo adotado, prazo ótimo e prazo do edital.

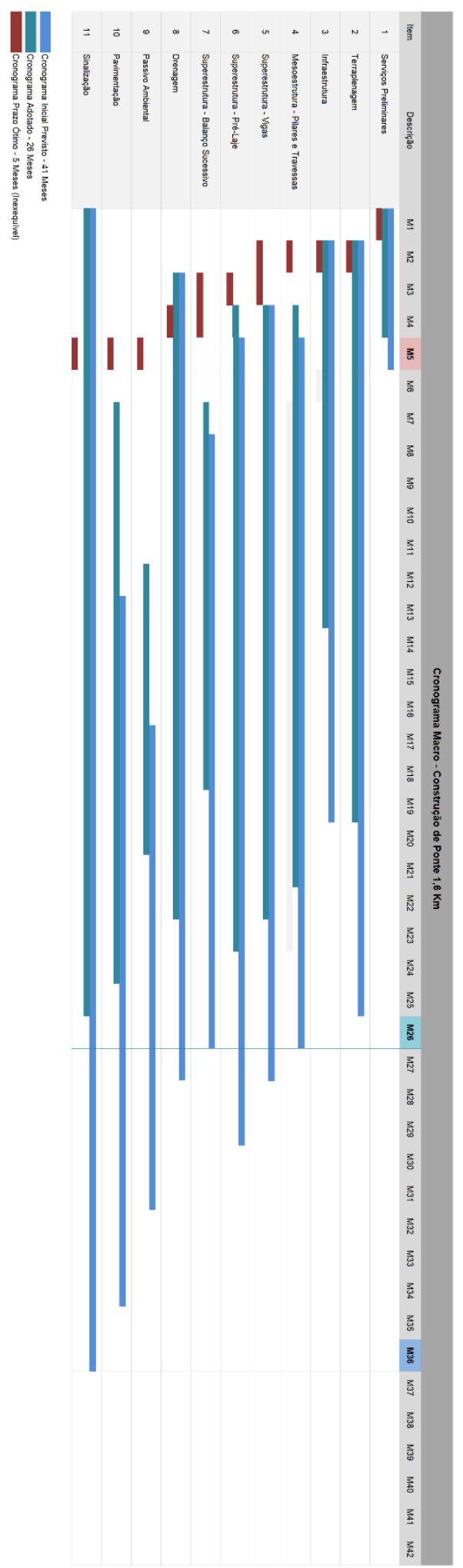

Figura 17 - Cronograma Prazo Previsto $\times$ Adotado = Prazo Ótimo 
Conforme abordado no início do trabalho, o método pode ser utilizado para um cálculo aproximado do nível de redução de custos possível e serve como uma ferramenta para direcionar os orçamentistas no estudo aprofundado do projeto em relação ao prazo a ser adotado. Muitas vezes, questões secundárias, como os critérios de desembolso do cliente ou a impossibilidade de redução tão grande de prazo prevista em edital, podem fazer com que o novo prazo a ser adotado seja obrigatoriamente diferente.

Independentemente das questões acima levantadas, após todo este estudo, é fundamental que seja feito novamente o orçamento detalhado para o cálculo do valor real do projeto.

Além dos cálculos efetuados acima das economias de custos entre o prazo de edital de 36 meses e o prazo mínimo de 26 meses, faz-se o cálculo entre o prazo mínimo - o caminho crítico e o prazo ótimo de 5 meses. A economia gerada entre estes prazos seria de $R \$ 11 \mathrm{MM}$. Este valor é extremamente importante para as empresas que buscam inovação, pois é um valor que elas podem considerar como contrapartida para o investimento em inovações tecnológicas que poderiam reduzir o prazo do projeto. Qualquer inovação que custasse menos de $R \$ 11 \mathrm{MM}$ e reduzisse o prazo do caminho crítico ao prazo ótimo do projeto seria um investimento que valeria a pena.

Quadro 43 - Cálculo da zona de potencial de inovação

\begin{tabular}{|l|c|}
\hline Zona de Inovação & $\mathrm{R} \$ 18.788 .462$ \\
\hline Custos variáveis - 26 meses & $\mathrm{R} \$ 7.374 .030$ \\
\hline Custos variáveis - 5 meses & $\mathbf{R} \$ \mathbf{1 1 . 4 1 4 . 4 3 2}$ \\
\hline
\end{tabular}

\subsection{ESTUDO DE CASO 2 - CONDOMÍNIO DE 45 CASAS}

Conforme já descrito anteriormente, este é um estudo de caso ao qual o autor tem menos familiaridade profissional, desta forma deve ser considerado como um exemplo secundário quando comparado ao primeiro estudo de caso.

Para a aplicação da metodologia, utiliza-se todas as sete etapas desenvolvidas no Item 3.1.4, conforme abaixo.

\subsubsection{CARACTERIZAÇÃO DO OBJETO}

Inicialmente determinam-se as características básicas do projeto:

- O escopo do projeto é a execução dos serviços necessários para a construção de condomínio fechado composto por 45 casas com área construída média de $141,11 \mathrm{~m}^{2}$. A tipologia-padrão é de casas de três quartos, sendo duas suítes e um quarto adicional, havendo também sala social, sala de televisão e cozinha-padrão 
- Regime de Contratação: Projeto Privado de Empresa de Construção

- Modo de disputa: Não há

- Preço-base orçado: $\mathrm{R} \$ 11,43 \mathrm{MM}(2020)$

- Prazo de Contrato Original: 41 meses

- Valores do orçamento: ano 2020

- Principais atividades:

- Execução e Montagem de Lajes pré-moldadas;

- Execução de Alvenaria;

- Execução de Emboço;

- Instalações Elétricas;

- Estrutura de aço para telha;

- Assentamento de Porcelanato com argamassa pré-fabricada.

- Área para canteiro de obra e industrial: aproximadamente $273 \mathrm{~m}^{2}$.

Plantas e referências do projeto e maior detalhamento dos sistemas construtivos:

Inicialmente segue planta que simula condomínio de casas a ser construído.

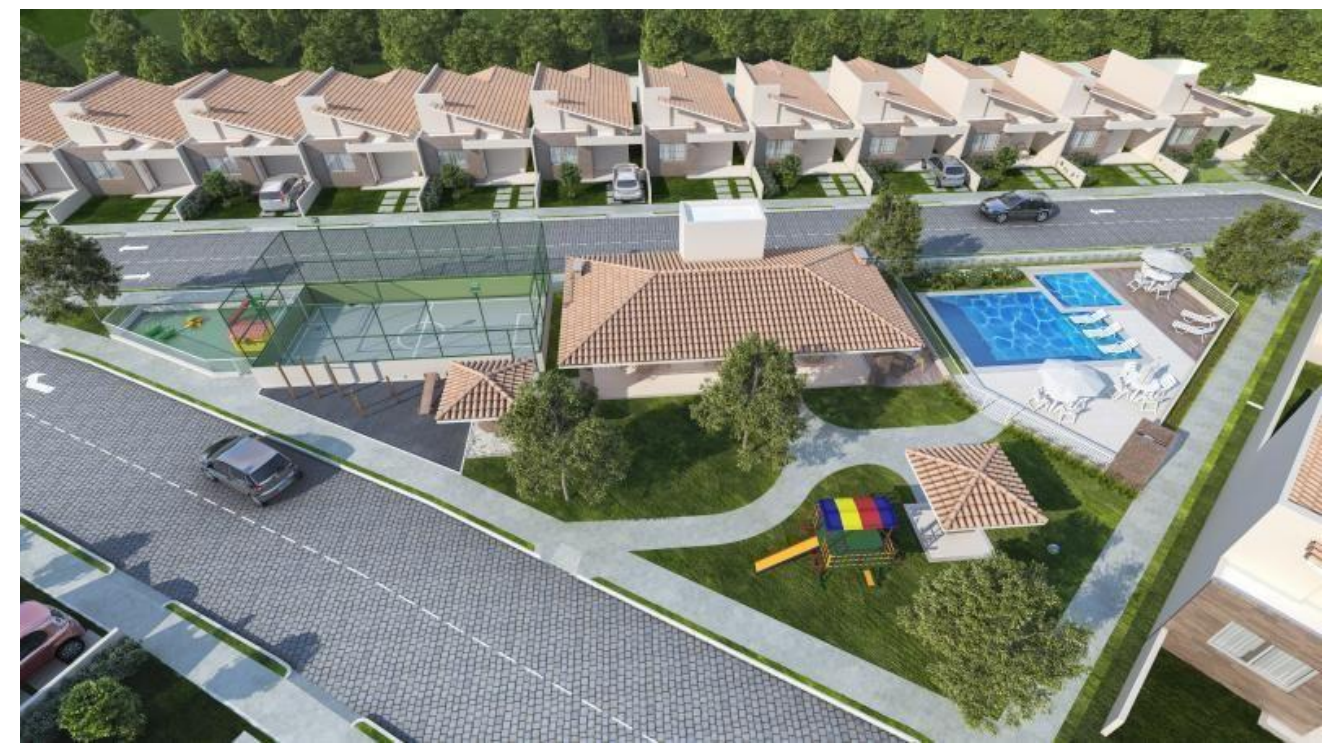

Figura 18 - Planta do condomínio de casas (exemplo).

Fonte: https://www.bcimobiliaria.com.br/imovel/782100/casa-em-condominio-venda-nossa-senhorado-socorro-se-centro 


\section{Infraestrutura e fundações}

- Estacas: as estacas das casas serão executadas por sistema manual em trado. Os diâmetros são de 0,25 m.

- Estrutura: Vigas baldrame, blocos e pilares em concreto armado, executados em sistema tradicional. As lajes são pré-fabricadas e preenchidas com lajotas de cerâmica.

- Acabamentos: Os acabamentos serão executados em piso porcelanato, em reboco e pintura acrílica nas paredes.

\subsubsection{PARÂMETROS DE REFERÊNCIA DAS VARIÁVEIS DA EQUAÇÃO}

Para o cálculo das variáveis das equações dos custos e prazos, foram determinados os 16 parâmetros fundamentais para a concepção da curva de variabilidade dos custos e do prazo ótimo teórico, conforme as Equações (16) e (18) e o Quadro 13. Do Quadro 44 ao Quadro 68, cada uma das partes do Quadro 13 é particionada juntamente com as memórias e justificativas de cada um dos itens da equação.

Quadro 44 - Identificação dos Indicadores da Equação de Prazo Ótimo - Item M’t

\begin{tabular}{|l|l|l|l|}
\hline Item & Descrição & Determinação & Resultado \\
\hline M't & $\begin{array}{l}\text { Quantitativo total de mão de } \\
\text { obra orçada para a execução } \\
\text { do projeto em um mês }\end{array}$ & $\begin{array}{l}\text { A determinação foi feita pela } \\
\text { multiplicação de todos os } \\
\text { quantitativos de serviços da } \\
\text { obra levantados multiplicados } \\
\text { por suas respectivas } \\
\text { composições para mão de obra }\end{array}$ & $\begin{array}{l}1.961 \text { funcionários, sendo } \\
392 \text { pedreiros, } 184 \\
\text { carpinteiros, } 1.033 \\
\text { serventes, entre outros }\end{array}$ \\
\hline
\end{tabular}

Com o uso dos dados do Quadro 45 apresentado, foi possível efetuar o cálculo do Item M't que equivale ao quantitativo total de mão de obra direta para executar o projeto em apenas um mês. O valor total de homem-hora trabalhada, apresentada na primeira coluna da tabela e que totaliza 345.099 horas no projeto, foi obtido através do uso de softwares de cálculo, em que todos os quantitativos de serviços, conforme 0

Quadro 46, foram multiplicados por suas respectivas composições de serviços. A quantidade do efetivo em um mês foi obtida pela divisão das 345.099 horas por 176 horas, que é o período médio efetivamente trabalhado pelos funcionários por mês, gerando, assim, uma necessidade de aproximadamente 1.961 funcionários caso 0 projeto fosse executado em um único mês. 
Quadro 45 - Identificação dos Indicadores da Equação de Prazo Ótimo - Item M’t

\begin{tabular}{|l|c|c|c|c|}
\cline { 2 - 5 } \multicolumn{1}{c|}{} & $\mathbf{1 7 6 , 0 0 ~ H H}$ & \multicolumn{3}{c|}{ Ponderações } \\
\hline Função & HH Trab. & Qtde Mês & \multicolumn{2}{c|}{ Salário (R\$) } \\
\hline Ajudante & 181.841 & 1.033 & 1.705 & 1.761 .685 \\
\hline Armador & 4.938 & 28 & 2.074 & 58.203 \\
\hline Carpinteiro & 32.248 & 183 & 2.074 & 380.059 \\
\hline Eletricista/encanador & 33.667 & 191 & 2.563 & 490.339 \\
\hline Montador & 198 & 1 & 2.335 & 2.629 \\
\hline Pedreiro & 68.900 & 393 & 2.074 & 812.022 \\
\hline Pintor & 23.305 & 132 & 2.074 & 274.660 \\
\hline TOTAL & 345.099 & 1.961 & & 3.779 .600 \\
\hline Salário Médio & & & & 1.927 \\
\hline
\end{tabular}

Quadro 46 - Quantitativo de resumo de serviços

\begin{tabular}{|c|c|c|c|}
\hline Item & Descrição & Und & Qtde \\
\hline 1 & $\begin{array}{l}\text { Laje pré-fabricada comum para forro, intereixo } 38 \mathrm{~cm} \text {, espessura da } \\
\text { laje } 12 \mathrm{~cm} \text {, capeamento } 4 \mathrm{~cm} \text {, elemento de enchimento } 8 \mathrm{~cm}\end{array}$ & $\mathrm{~m}^{2}$ & 7.027 \\
\hline 2 & $\begin{array}{l}\text { Alvenaria de vedação com blocos cerâmicos furados, } 14 \times 14 \times 24 \\
\text { cm, espessura da parede } 14 \mathrm{~cm} \text {, juntas de } 10 \mathrm{~mm} \text { com argamassa } \\
\text { industrializada }\end{array}$ & $\mathrm{m}^{2}$ & 13.633 \\
\hline 3 & $\begin{array}{l}\text { Emboço para parede externa com argamassa mista de cimento, cal } \\
\text { hidratada e areia sem peneirar traço } 1: 2: 6, e=30 \mathrm{~mm}\end{array}$ & $\mathrm{~m}^{2}$ & 13.823 \\
\hline 4 & Elétrica - Fiação - Item único & $\mathrm{vb}$ & 1 \\
\hline 5 & $\begin{array}{l}\text { Emboço para parede interna com argamassa de cal hidratada e } \\
\text { areia sem peneirar traço } 1: 4,5 \text {, com betoneira, } e=30 \mathrm{~mm}\end{array}$ & $\mathrm{~m}^{2}$ & 17.791 \\
\hline 6 & $\begin{array}{l}\text { EC01 - Estrutura de aço para telha ondulada de fibrocimento, } \\
\text { alumínio ou plástica, ancorada em laje ou parede }\end{array}$ & und & 43 \\
\hline 7 & $\begin{array}{l}\text { Porcelanato assentado com argamassa pré-fabricada de cimento } \\
\text { colante (dimensão: } 60 \times 60 \mathrm{~cm} \text { ) }\end{array}$ & $\mathrm{m}^{2}$ & 3.524 \\
\hline 8 & Esgoto & $\mathrm{vb}$ & 1 \\
\hline 9 & $\begin{array}{l}\text { Porcelanato assentado com argamassa pré-fabricada de cimento } \\
\text { colante (dimensão: } 60 \times 60 \mathrm{~cm} \text { ) }\end{array}$ & $\mathrm{m}^{2}$ & 3.275 \\
\hline 10 & $\begin{array}{l}\text { Pintura com tinta látex PVA em parede interna, com duas demãos, } \\
\text { sem massa corrida }\end{array}$ & $\mathrm{m}^{2}$ & 15.481 \\
\hline 11 & $\begin{array}{l}\text { CX01 - Janela de alumínio sob encomenda, colocação e } \\
\text { acabamento, de correr, com contramarcos }(160 \times 120 \mathrm{~cm})\end{array}$ & und & 131 \\
\hline 12 & $\begin{array}{l}\text { Forma para vigas, com chapa compensada plastificada, e }=12 \mathrm{~mm}, 5 \\
\text { reaproveitamentos }\end{array}$ & $\mathrm{m}^{2}$ & 6.064 \\
\hline 13 & $\begin{array}{l}\text { Forma de madeira para fundação, com tábuas e sarrafos, } 3 \\
\text { aproveitamentos }\end{array}$ & $\mathrm{m}^{2}$ & 3.736 \\
\hline 14 & $\begin{array}{l}\text { Emboço em teto com argamassa mista de cimento, cal hidratada e } \\
\text { areia sem peneirar traço } 1: 2: 9, e=20 \mathrm{~mm}\end{array}$ & $\mathrm{~m}^{2}$ & 6.439 \\
\hline
\end{tabular}




\begin{tabular}{|c|l|c|c|}
\hline 15 & Eletroduto de PVC flexível corrugado (elétrica/telefônica/antena) & $\mathrm{ml}$ & 2.925 \\
\hline 16 & $\begin{array}{l}\text { Emassamento de parede interna com massa corrida à base de PVA } \\
\text { com duas demãos, para pintura látex }\end{array}$ & $\mathrm{m}^{2}$ & 20.299 \\
\hline 17 & $\begin{array}{l}\text { Cobertura com telha de fibrocimento uma água, perfil ondulado, e }= \\
6 \mathrm{~mm}, \text { altura 125 mm, largura útil 1.020 mm e largura nominal 1.064 } \\
\mathrm{mm}, \text { inclinação 27\% }\end{array}$ & $\mathrm{m}^{2}$ & 5.529 \\
\hline 18 & Lastro de concreto não estrutural, espessura $6 \mathrm{~cm}$ & $\mathrm{~m}^{3}$ & 5.771 \\
\hline 19 & Quadros e disjuntores & und & 52 \\
\hline 20 & Concreto estrutural dosado em central, autoadensável, fck 20 MPa & $\mathrm{m}^{2}$ & 589 \\
\hline
\end{tabular}

Além dos quantitativos de horas estimadas, também foi computado o valor de remuneração média ponderada para esses trabalhadores. Tal parâmetro também será utilizado mais à frente para o cálculo das rescisões e de outros fatores. $O$ valor final computado foi de $R \$ 1.927$ de remuneração média de base, o qual pode ser observado no Quadro 45.

Quadro 47 - Identificação dos Indicadores da Equação de Prazo Ótimo - Item Sm

\begin{tabular}{|l|l|l|l|}
\hline Item & Descrição & Determinação & Resultado \\
\hline $\mathrm{Sm}$ & $\begin{array}{l}\text { Salário Médio Mensal dos } \\
\text { Funcionários de Produção }\end{array}$ & $\begin{array}{l}\text { A determinação deste valor } \\
\text { deve ser feita pela média } \\
\text { ponderada dos salários da } \\
\text { produção e seus respectivos } \\
\text { quantitativos }\end{array}$ & $\begin{array}{l}\text { R\$ 1.927. Valor de } \\
\text { salários médios dos } \\
\text { funcionários de produção } \\
\text { da obra ponderados pelas } \\
\text { quantidades, conforme } \\
\text { abordado acima. }\end{array}$ \\
\hline
\end{tabular}

Para o cálculo do Fator Mat'0, deve-se somar todos os custos de materiais que compõem a obra. O Quadro 48 contém o resumo dos principais custos.

Quadro 48 - Quadro de resumo com principais materiais da Obra

\begin{tabular}{|c|l|c|c|}
\hline Item & Descrição & Unidade & Quantidade \\
\hline 1 & $\begin{array}{l}\text { Concreto dosado em central autoadensável (resistência: } 20 \\
\text { MPa) }\end{array}$ & $\mathrm{m}^{3}$ & 1.601 \\
\hline 2 & Porcelanato ROCA - Titan Cinza 60x60 & $\mathrm{m}^{2}$ & 6.379 \\
\hline 3 & Cimento Portland CP II-E-32 (resistência: 32,00 MPa) & $\mathrm{Kg}$ & 563.757 \\
\hline 4 & $\begin{array}{l}\text { Bloco cerâmico de vedação (altura: } 140 \mathrm{~mm} / \text { comprimento: } \\
\text { 240 mm/largura: } 140 \mathrm{~mm})\end{array}$ & $\mathrm{m}^{2}$ & 465.266 \\
\hline 5 & Porcelanato ROCA - Ferrand BL $(60$ x 60 cm) RET & $\mathrm{m}^{2}$ & 4.480 \\
\hline 6 & $\begin{array}{l}\text { CX01 - Caixilho de alumínio de correr com duas folhas } \\
\text { venezianas e uma de vidro temperado 8 mm com } \\
\text { acabamento branco }\end{array}$ & Und & 131 \\
\hline 7 & $\begin{array}{l}\text { Telha de fibrocimento estrutural tipo etermax e maxiplac } \\
\text { (espessura: 6 mm/largura nominal: } 1064 \mathrm{~mm} / \text { largura útil: } 1020\end{array}$ & $\mathrm{~m}^{2}$ & 6.137 \\
\hline
\end{tabular}




\begin{tabular}{|c|l|c|c|}
\hline & mm/vão livre: 3,96 m) & $\mathrm{Kg}$ & 41.199 \\
\hline 8 & $\begin{array}{l}\text { Barra de aço CA-50 3/8" (bitola: 10,00 mm/massa linear: } \\
0,617 \mathrm{~kg} / \mathrm{m})\end{array}$ & Und & 43 \\
\hline 9 & $\begin{array}{l}\text { PB02 - Porta balcão de alumínio, de correr, três folhas, com } \\
\text { vidro temperado 8 mm 2,90 x 2,15 m. }\end{array}$ & Und & 45 \\
\hline 10 & Material Z-275 para cobertura metálica & $\mathrm{m}^{3}$ & 2.689 \\
\hline 11 & Areia lavada tipo média & $\mathrm{Kg}$ & 299.546 \\
\hline 12 & Argamassa pré-fabricada para assentamento de alvenaria & $\mathrm{Ml}$ & 81.875 \\
\hline 13 & $\begin{array}{l}\text { Cabo flexível PVC baixa tensão unipolar encordoamento } \\
\text { classe 5 (seção transversal: 2,5 mm²/temperatura máxima do } \\
\text { condutor: 70/tensão 450/750 V) }\end{array}$ & $\mathrm{Kg}$ & 27.603 \\
\hline 15 & $\begin{array}{l}\text { Barra de aço CA-50 5/16" (massa linear: 0,395 kg/m/bitola: } \\
8,00 \text { mm) }\end{array}$ & $\mathrm{Kg}$ & 12.194 \\
\hline 16 & $\begin{array}{l}\text { Tela de aço CA-60 soldada tipo Q 92 tipo malha quadrangular } \\
\text { (diâmetro do fio: 4,20 mm/dimensões da trama 150x150 mm ) }\end{array}$ & $\mathrm{Kg}$ & 238.754 \\
\hline 17 & Cal hidratada CH III & $\mathrm{Kg}$ & 77.874 \\
\hline 18 & $\begin{array}{l}\text { PB01 - Porta balcão de alumínio, de correr, três folhas, com } \\
\text { vidro temperado 8 mm 1,55 x 2,15 m }\end{array}$ \\
\hline 19 & $\begin{array}{l}\text { Argamassa de cimento colante pré-fabricada para } \\
\text { assentamento de peças cerâmicas tipo porcelanato }\end{array}$ & \\
\hline
\end{tabular}

Quadro 49 - Identificação dos Indicadores da Equação de Prazo Ótimo - Item Mat'0

\begin{tabular}{|l|l|l|l|}
\hline Item & Descrição & Determinação & Resultado \\
\hline Mat'0 & $\begin{array}{l}\text { Custo total dos materiais para } \\
\text { a elaboração da obra }\end{array}$ & $\begin{array}{l}\text { A determinação deste fator } \\
\text { envolve a multiplicação de todos } \\
\text { os quantitativos de serviços da } \\
\text { obra levantados multiplicados } \\
\text { por suas respectivas } \\
\text { composições para materiais }\end{array}$ & $\begin{array}{l}\mathrm{R} \$ 5.368 .417 \text { de custos de materiais, } \\
\text { sendo compostos por } \\
\text { todos os materiais } \\
\text { necessários à execução } \\
\text { da obra: cimento, aço e } \\
\text { agregados. }\end{array}$ \\
\hline
\end{tabular}

Quadro 50 - Identificação dos Indicadores da Equação de Prazo Ótimo - Itens Eq’t e C

\begin{tabular}{|l|l|l|l|}
\hline Item & Descrição & Determinação & Resultado \\
\hline Eq't & $\begin{array}{l}\text { Quantitativo total de } \\
\text { equipamentos orçados para a } \\
\text { execução do projeto em um } \\
\text { mês }\end{array}$ & $\begin{array}{l}\text { A determinação deste fator foi } \\
\text { feita pela multiplicação de todos } \\
\text { os quantitativos de serviços da } \\
\text { obra levantados multiplicados } \\
\text { por suas respectivas } \\
\text { composições para } \\
\text { equipamentos }\end{array}$ & $\begin{array}{l}\text { caminhomentos, sendo 2 } \\
\text { compactadosculantes, 8 } \\
\text { vibratórios, 1 pá } \\
\text { carregadeira, 2 } \\
\text { escavadeiras, entre outros }\end{array}$ \\
\hline C & $\begin{array}{l}\text { Custo Mobilização } \\
\text { Equipamentos }\end{array}$ & $\begin{array}{l}\text { A determinação dos custos de } \\
\text { mobilização dos equipamentos } \\
\text { foi feita pela determinação das } \\
\text { distâncias de onde os } \\
\text { equipamentos vão sair até a a } \\
\text { obra e a cotação ou estimativa }\end{array}$ & $\begin{array}{l}\text { Para este projeto de } \\
\text { construção de casas, o } \\
\text { quantitativo de }\end{array}$ \\
$\begin{array}{l}\text { equipamentos } \\
\text { necessários para total } \\
\text { execução do projeto é }\end{array}$ \\
\hline
\end{tabular}




\begin{tabular}{|l|l|l|}
\hline & $\begin{array}{l}\text { dos preços para que tal } \\
\text { transporte seja efetuado. A } \\
\text { partir da determinação destes } \\
\text { fatores para cada um dos } \\
\text { equipamentos, os custos foram } \\
\text { calculados. }\end{array}$ & $\begin{array}{l}\text { praticamente irrelevante } \\
\text { (praticamente 10 } \\
\text { equipamentos devem ser } \\
\text { mobilizados), desta } \\
\text { maneira, este parâmetro } \\
\text { foi desconsiderado }\end{array}$ \\
\hline
\end{tabular}

Quadro 51 - Identificação dos Indicadores da Equação de Prazo Ótimo - Item C’t

\begin{tabular}{|l|l|l|l|}
\hline Item & Descrição & Determinação & Resultado Exemplo \\
\hline Cl't & $\begin{array}{l}\text { Custo indireto do efetivo mais } \\
\text { gastos gerenciais mensais }\end{array}$ & $\begin{array}{l}\text { A determinação deste fator } \\
\text { envolveu a determinação do } \\
\text { organograma e do efetivo } \\
\text { indireto médio mensal da obra, } \\
\text { além da determinação dos } \\
\text { custos gerenciais médios } \\
\text { mensais }\end{array}$ & $\begin{array}{l}\mathrm{R} \$ 77.115 \text { de custos } \\
\text { indiretos médios mensais, } \\
\text { sendo } \mathrm{R} \$ 55.872 \\
\text { referentes aos salários de } \\
\text { equipe e } \mathrm{R} \$ 21.243 \\
\text { referentes aos custos de } \\
\text { manutenção de canteiro }\end{array}$ \\
\hline
\end{tabular}

Para o cálculo dos custos indiretos, usou-se o histograma de mão de obra contendo todo o efetivo indireto composto por engenheiros, técnicos, auxiliares, estagiários e aprendizes. Uma vez feito o histograma deste efetivo, é possível calcular os valores médios mensais. Desta forma, chegou-se a um efetivo médio mensal de 8 funcionários com um custo médio de $R \$ 55.872$ mensais, considerando os encargos sociais devidos, conforme disposto no Quadro 52.

Quadro 52 - Identificação dos custos do efetivo indireto mensal médio

\begin{tabular}{|l|c|c|}
\hline \multicolumn{1}{|c|}{ Indireto mensal médio } & Qtde & Valor (R\$) \\
\hline Engenharia e Área Técnica & 5 & 43.790 \\
\hline Técnicos, Auxiliares e Estagiários & 3 & 12.082 \\
\hline Total administração da obra & $\mathbf{8}$ & $\mathbf{5 5 . 8 7 2}$ \\
\hline
\end{tabular}

No Quadro 53, é possível obter um valor médio para os custos indiretos mensais decorrentes de despesas de canteiro, contas de consumo e verbas mensais para os custos de apoio. Ao final, chega-se a um custo aproximado mensal de $\mathrm{R} \$ 21.243$.

Quadro 53 - Identificação das despesas indiretas médias de canteiro e apoio

\begin{tabular}{|c|l|c|}
\hline Item & Descrição & Valor (R\$) \\
\hline 1 & Controle tecnológico e ensaios de materiais & 1.328 \\
\hline 2 & Contêineres - vestiário, almoxarifado, escritório & 1.754 \\
\hline 3 & Vigilância & 2.350 \\
\hline 4 & Advogados & 5.324 \\
\hline 5 & Relatórios fotográficos & 359 \\
\hline 6 & Consultores & 3.298 \\
\hline
\end{tabular}




\begin{tabular}{|c|l|c|}
\hline 7 & Assinaturas, correios & 124 \\
\hline 8 & Transportes, táxis & 73 \\
\hline 9 & Cópias & 289 \\
\hline 10 & Sindicatos & 1.065 \\
\hline 11 & Consumo mensal - energia elétrica & 2.748 \\
\hline 12 & Consumo mensal - água e esgoto & 429 \\
\hline 13 & Despesas com telefone fixo & 198 \\
\hline 14 & Despesas com celular & 315 \\
\hline 15 & Despesas internas com coleta de lixo & 439 \\
\hline 16 & Material de escritório & 122 \\
\hline 17 & Materiais de consumos diversos & 153 \\
\hline 18 & Equipamentos de segurança - indiretos & 873 \\
\hline Total & & $\mathbf{2 1 . 2 4 3}$ \\
\hline
\end{tabular}

Quadro 54 - Identificação dos Indicadores da Equação de Prazo Ótimo - Item A

\begin{tabular}{|c|c|c|c|}
\hline Item & Descrição & Determinação & Resultado \\
\hline A & Custo Rescisões & $\begin{array}{l}\text { A determinação dos custos das } \\
\text { rescisões trabalhistas envolveu } \\
\text { a aplicação e análise de } \\
\text { parâmetros setoriais e de } \\
\text { legislação que contemplam os } \\
\text { passivos que ocorrem durante a } \\
\text { rescisão dos funcionários. } \\
\text { Fatores como aviso prévio, } \\
\text { aviso prévio indenizado, férias, } \\
13^{\circ} \text { proporcional, multas de } \\
\text { FGTS, entre outros, devem ser } \\
\text { considerados }\end{array}$ & $\begin{array}{l}\text { Índice } 1,27 \text {, ou seja, para } \\
\text { cada funcionário } \\
\text { contratado que será } \\
\text { demitido no futuro, } 1,27 \\
\text { salário adicional deverá } \\
\text { ser pago }\end{array}$ \\
\hline
\end{tabular}

Para o cálculo dos custos das rescisões trabalhistas, utilizou-se o Quadro 54, no qual diversos fatores foram ponderados conforme a legislação vigente. Dentre os fatores estão FGTS - Fundo de Garantia do Tempo de Serviço, indenizações por demissão e férias e $13^{\circ}$ proporcionais às indenizações. Neste caso, chega-se a um fator de 1,27, o que significa que, ao final do projeto, em média, todo funcionário receberá 1,27 salário a mais que a sua média salarial, decorrente de encargos rescisórios.

Ressalta-se que, neste parâmetro, foram considerados apenas os indicadores que refletem encargos que gerariam custos adicionais no caso da variabilidade do prazo do projeto. Fatores como, por exemplo, a multa sobre o FGTS não entra nesta conta, pois, em qualquer circunstância, os valores pagos seriam os mesmos porque a envoltória financeira é a mesma. Já os encargos de aviso prévio, não. Eles dependem do quantitativo do efetivo que foi contratado para o projeto, e cada funcionário, ao final de seu período de trabalho, receberá tal verba indenizatória. 
Outro ponto importante para salientar é a questão da temporalidade dos projetos. Como os projetos são temporais, foi considerado que todos os funcionários diretos serão demitidos em seu término, fato que gera todos estes custos indenizatórios abordados.

Para o cálculo completo do Fator $A$, somam-se os fatores abordados. Como o salário médio do efetivo foi determinado durante o cálculo do Item M't, e é de $R \$$ 1.927, o valor rescisório médio devido a cada funcionário adicional contratado seria de $A$ x Salário Médio = 1,27 x $1.927=\mathrm{R} \$ 2.456$ por funcionário.

Quadro 55 - Identificação do fator de rescisão (A)

\begin{tabular}{|l|c|}
\hline Item & Fator \\
\hline Aviso prévio indenizado & 1 \\
\hline Férias sobre aviso & 0,11 \\
\hline FGTS sobre aviso & 0,08 \\
\hline 13o sobre aviso & 0,08 \\
\hline Fator $\mathbf{A}$ & $\mathbf{1 , 2 7}$ \\
\hline
\end{tabular}

Quadro 56 - Identificação dos Indicadores da Equação de Prazo Ótimo - Item B

\begin{tabular}{|l|l|l|l|}
\hline Item & Descrição & Determinação & Resultado \\
\hline B & Redução de Produtividade & $\begin{array}{l}\text { Deve ser determinada uma } \\
\text { constante fixa que seja } \\
\text { inversamente variável ao prazo }\end{array}$ & $\begin{array}{l}\text { Para a utilização deste } \\
\text { exemplo prático, o Fator B } \\
\text { e que determine a redução da } \\
\text { produtividade em decorrência } \\
\text { das reduções de prazo do } \\
\text { projeto. }\end{array}$ \\
\hline
\end{tabular}

Quadro 57 - Identificação dos Indicadores da Equação de Prazo Ótimo - Item D

\begin{tabular}{|c|c|c|c|}
\hline Item & Descrição & Determinação & Resultado \\
\hline D & Custo Canteiro de Obras & $\begin{array}{l}\text { A determinação dos custos dos } \\
\text { canteiros de obras e instalações } \\
\text { foi realizada conforme cotações } \\
\text { de preços para esta } \\
\text { implantação do uso do histórico } \\
\text { existente na empresa e por } \\
\text { estimativas existentes em } \\
\text { revistas técnicas e } \\
\text { especializadas. }\end{array}$ & $\begin{array}{l}\text { R } \$ 375 \text { por funcionário, } \\
\text { com o aumento do } \\
\text { número de funcionários } \\
\text { no projeto devido à } \\
\text { redução de prazos, as } \\
\text { estruturas de canteiro } \\
\text { devem aumentar, desta } \\
\text { forma, uma média de } \\
\text { acréscimo de custo por } \\
\text { funcionário deve ser } \\
\text { estabelecida. }\end{array}$ \\
\hline
\end{tabular}


Quadro 58 - Identificação do Item D - custos variáveis de canteiro

\begin{tabular}{|c|c|c|}
\hline Item & V. Fixo (R\$) & V. Variável (R\$/Efetivo) \\
\hline Canteiro - Obras & 25.706 & 347 \\
\hline Canteiro - Almoxarifado & 6.169 & 24 \\
\hline Canteiro - Ind. & 2.408 & 4,35 \\
\hline \multicolumn{2}{|c|}{ Total } & $\mathbf{3 7 5}$ \\
\hline
\end{tabular}

Quadro 59 - Identificação dos Indicadores da Equação de Prazo Ótimo - Item E

\begin{tabular}{|l|l|l|l|}
\hline Item & Descrição & Determinação & Resultado \\
\hline E & Custos QSMS, treinamentos & $\begin{array}{l}\text { A determinação dos custos de } \\
\text { treinamentos de QSMS foi feita }\end{array}$ & $\begin{array}{l}\text { R\$ } 59 \text { é o custo de } \\
\text { treinamentos que cada } \\
\text { através da estimativa das horas } \\
\text { médias expendidas durante os } \\
\text { funcionário tem ao entrar } \\
\text { treinamentos necessários de } \\
\text { QSMS da empresa, integrações } \\
\text { e atividades complementares. A } \\
\text { integrações, aos às } \\
\text { treinamentos de } \\
\text { partir da determinação do tempo } \\
\text { médio expendido para tais } \\
\text { atividades, multiplicou-se tal } \\
\text { valor pelo valor médio horário } \\
\text { do funcionário. }\end{array}$ \\
\hline
\end{tabular}

Quadro 60 - Identificação dos custos médios de treinamento por funcionário

\begin{tabular}{|l|cc|}
\hline Item & Horas & Valor (R\$) \\
\hline Treinamentos & 4,0 & 59 \\
\hline
\end{tabular}

Quadro 61 - Identificação dos Indicadores da Equação de Prazo Ótimo - Item F

\begin{tabular}{|c|c|c|c|}
\hline Item & Descrição & Determinação & Resultado \\
\hline $\mathrm{F}$ & $\begin{array}{l}\text { Custos EPI + Exames } \\
\text { médicos }\end{array}$ & $\begin{array}{l}\text { A determinação dos custos de } \\
\text { ferramentas adicionais e dos } \\
\text { EPIs que a empresa fornece } \\
\text { aos funcionários também deve } \\
\text { ser realizada a partir de } \\
\text { cotações de preços e média de } \\
\text { gastos estimados. Estes fatores } \\
\text { se caracterizam por ter uma } \\
\text { quantidade fixa durante o início } \\
\text { e o término do projeto (exames } \\
\text { admissionais e demissionais) e } \\
\text { também por substituição ou } \\
\text { acompanhamento (exames } \\
\text { periódicos). }\end{array}$ & $\begin{array}{l}\mathrm{R} \$ 99 \text { fixos (Exames) + } \\
\mathrm{R} \$ 176 \text { fixos (EPIs) + R\$ } \\
5,15 \text { por mês por } \\
\text { funcionário (Exames) + } \\
\mathrm{R} \$ 43 \text { por mês por } \\
\text { funcionário (EPIs). Os } \mathrm{R} \$ \\
99 \text { e } \mathrm{R} \$ 176 \text { se referem } \\
\text { aos custos de exames } \\
\text { admissionais e } \\
\text { demissionais que cada } \\
\text { funcionário deverá fazer, } \\
\text { além da soma dos } \\
\text { uniformes e EPIs que } \\
\text { cada funcionário recebe. } \\
\text { Os } R \$ 5,15 \text { e } R \$ 43 \text { são } \\
\text { referentes aos custos de } \\
\text { trocas e substituição de }\end{array}$ \\
\hline
\end{tabular}




\begin{tabular}{|l|l|l|l|}
\hline & & & $\begin{array}{l}\text { uniformes e EPIs, além } \\
\text { dos custos médios de } \\
\text { exames periódicos. }\end{array}$ \\
\hline
\end{tabular}

Quadro 62 - Identificação dos custos fixos e variáveis do Item F

\begin{tabular}{|l|c|c|}
\hline Item & Custo fixo $(\mathbf{R} \$)$ & $\begin{array}{c}\text { Custo Variável } \\
\text { (R\$/Prazo/Funcionário) }\end{array}$ \\
\hline Exames médicos & 99 & $\mathbf{5 , 1 5}$ \\
\hline EPI & 176 & $\mathbf{4 3}$ \\
\hline
\end{tabular}

Quadro 63 - Identificação dos Indicadores da Equação de Prazo Ótimo - Item G

\begin{tabular}{|l|l|l|l|}
\hline $\mathrm{G}$ & $\begin{array}{l}\text { Economia de Escala - } \\
\text { Suprimentos }\end{array}$ & $\begin{array}{l}\text { A determinação desta constante } \\
\text { inversamente proporcional ao de economia no valor } \\
\text { prazo implica em estimar algum }\end{array}$ & total dos materiais do \\
desconto no valor de todos os & economia função da \\
materiais que serão adquiridos a se & comprar os materiais em \\
no projeto. A compra de um & ordens de compras mais \\
quantitativo expressivo em um & expressivas. \\
prazo menor gera economia de & \\
escala e proporciona maiores & & \\
& descontos nas negociações. & \\
\hline
\end{tabular}

O Gráfico 18 mostra a evolução do Parâmetro G.

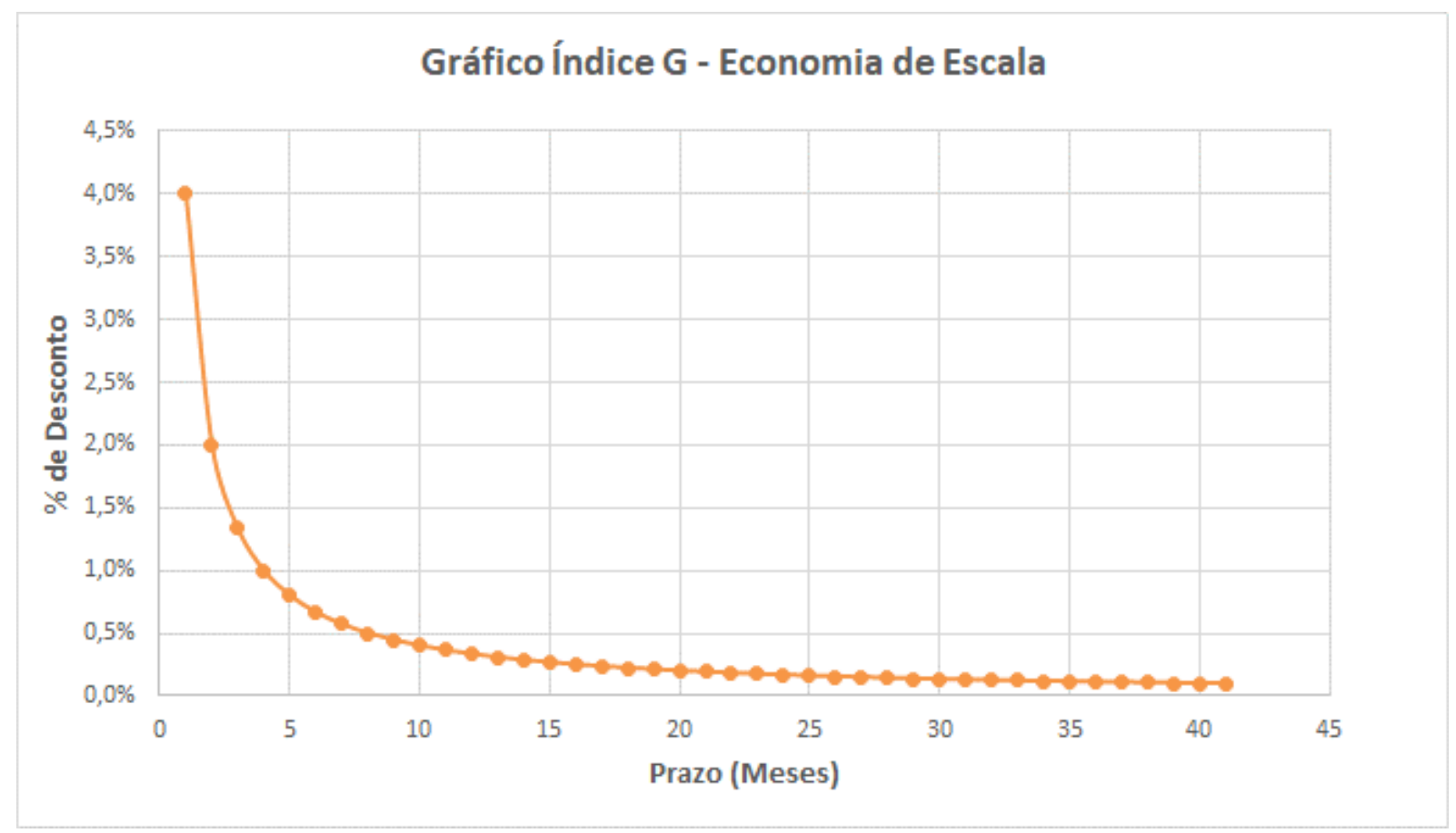

Gráfico 18 - Gráfico índice G - Condomínio de casas 
Quadro 64 - Identificação dos Indicadores da Equação de Prazo Ótimo - Item H

\begin{tabular}{|l|l|l|l|}
\hline Item & Descrição & Determinação & Resultado \\
\hline $\mathrm{H}$ & Aumento de horas extras & $\begin{array}{l}\text { Constante fixa inversamente } \\
\text { proporcional ao prazo do } \\
\text { projeto. Ao se reduzir o prazo } \\
\text { de um projeto, além de ser } \\
\text { gerados recursos de MO } \\
\text { adicionais, há uma tendência de } \\
\text { elevação nas horas extras (que } \\
\text { são mais caras que as horas } \\
\text { normais). }\end{array}$ & $\begin{array}{l}\text { Para este caso específico, } \\
\text { o aumento de horas }\end{array}$ \\
\hline
\end{tabular}

Quadro 65 - Identificação dos Indicadores da Equação de Prazo Ótimo - Item R

\begin{tabular}{|l|l|l|l|}
\hline Item & Descrição & Determinação & Resultado \\
\hline $\mathrm{R}$ & Índice de Rotatividade de MO & $\begin{array}{l}\text { A determinação do índice de } \\
\text { rotatividade de MO é obtida } \\
\text { através da experiência prévia do } \\
\text { orçamentista e das memórias } \\
\text { existentes de projetos em obras } \\
\text { e regiões similares. }\end{array}$ & $\begin{array}{l}\text { Índice adotado igual a 1,0 } \\
\text { para este projeto, por não } \\
\text { suficientes. }\end{array}$ \\
\hline
\end{tabular}

Quadro 66 - Identificação dos Indicadores da Equação de Prazo Ótimo - Item S

\begin{tabular}{|c|c|c|c|}
\hline Item & Descrição & Determinação & Resultado \\
\hline S & $\begin{array}{l}\text { Percentual de MO não } \\
\text { subcontratada }\end{array}$ & $\begin{array}{l}\text { A determinação do percentual } \\
\text { de MO não subcontratada } \\
\text { envolve a expertise de o } \\
\text { orçamentista determinar o tipo } \\
\text { de obra e o percentual médio de } \\
\text { serviços especializados que } \\
\text { normalmente são } \\
\text { subcontratados. Algumas obras } \\
\text { inclusive possuem instrumentos } \\
\text { contratuais que limitam ou } \\
\text { exigem um percentual mínimo } \\
\text { de subcontratação. }\end{array}$ & $\begin{array}{l}\text { Neste caso, não foi } \\
\text { necessário o cálculo do } \\
\text { fator, pois todas as } \\
\text { composições já } \\
\text { discriminaram quais } \\
\text { serviços seriam } \\
\text { subcontratados, então, } \\
\text { nas contas anteriores de } \\
\text { MO, já estavam } \\
\text { separados apenas os } \\
\text { funcionários que seriam } \\
\text { contratados. }\end{array}$ \\
\hline
\end{tabular}

Quadro 67 - Identificação dos Indicadores da Equação de Prazo Ótimo - Item K

\begin{tabular}{|c|c|c|c|}
\hline Item & Descrição & Determinação & Resultado Exemplo \\
\hline K & Fator majorador de pico & $\begin{array}{l}\text { A determinação do fator } \\
\text { majorador de pico envolve a } \\
\text { aplicação de um fator de pico } \\
\text { que faz com que seja } \\
\text { considerada a maior quantidade } \\
\text { de funcionários possível durante } \\
\text { a obra. Tal fator pode ser } \\
\text { calculado utilizando-se da } \\
\text { particularidade de as obras } \\
\text { seguirem um padrão de avanço } \\
\text { muito semelhante à Curva S. O }\end{array}$ & $\begin{array}{l}\text { Índice } 1,45 \text {, ou seja, no } \\
\text { pico, a maior quantidade } \\
\text { de funcionários que a } \\
\text { obra possuirá será de } \\
1,45 \text { multiplicado pela } \\
\text { quantidade média mensal } \\
\text { de funcionários (que pode } \\
\text { ser determinada por M't } \\
\text { dividido pelo prazo da } \\
\text { obra). Fator calculado de } \\
\text { acordo com a formulação }\end{array}$ \\
\hline
\end{tabular}




\begin{tabular}{|l|l|l|l|}
\hline & $\begin{array}{l}\text { detalhamento de como calcular } \\
\text { está descrito no Item 2.2 }\end{array}$ & $\begin{array}{l}\text { explorada anteriormente, } \\
\text { de acordo com os } \\
\text { parâmetros do projeto. }\end{array}$ \\
\hline
\end{tabular}

Quadro 68 - Identificação do fator de pico K

\begin{tabular}{|l|l|}
\hline PICO - DIST. NORMAL & \\
\hline Fator K - Pico & 1,45 \\
\hline
\end{tabular}

No Quadro 69, pode-se observar um resumo dos 16 fatores da equação de prazo ótimo.

Quadro 69 - Tabela de resumo de Indicadores da Equação de Prazo Ótimo

\begin{tabular}{|c|c|c|}
\hline Item & Descrição & Valor \\
\hline M't & MO para execução da Obra em um mês & 1.961 funcionários \\
\hline Sm & Salário médio dos funcionários, produção & $\mathrm{R} \$ 1.927 /$ funcionário \\
\hline Mat'0 & Custo total dos Materiais & $\mathrm{R} \$ 5.368 .417$ \\
\hline Cl't & Custo indireto médio mensal & $\mathrm{R} \$ 77.115 / \mathrm{mês}$ \\
\hline A & Custo Rescisões & 1,27 salário $=R \$ 2.456 /$ funcionário \\
\hline B & Perda de Produtividade (aumento efetivo) & Desprezado \\
\hline C & Custo Mobilização Equipamentos & Desprezado \\
\hline D & Custo Canteiro de Obras & $\mathrm{R} \$ 375 /$ funcionário \\
\hline$E$ & Custos QSMS, treinamentos & $\mathrm{R} \$ 59 /$ funcionário \\
\hline $\mathrm{F}$ & Custos EPI + Exames médicos & $\mathrm{R} \$ 276 /$ funcionário + $\mathrm{R} \$ 49 /$ mês/funcionário \\
\hline G & Economia de Escala - Suprimentos & 4\% de desconto máximo \\
\hline $\mathrm{R}$ & Índice de Rotatividade de MO & 1,0 \\
\hline$S$ & Percentual de MO não subcontratada & Não adotado \\
\hline K & Fator majorador de pico & 1,45 \\
\hline $\mathrm{H}$ & Aumento de Horas Extras & Não adotado \\
\hline
\end{tabular}

\subsubsection{DETERMINAÇÃO DO PRAZO ÓTIMO TEÓRICO}

A partir da determinação dos dezesseis parâmetros do item anterior, é realizado o cálculo da curva dos custos variáveis e, para a determinação do prazo ótimo, apenas fazendo a substituição dos parâmetros nas Equações (16) e (18). 


$$
\begin{aligned}
& C T A_{t}=\left(K R S \frac{M^{\prime}{ }_{t}}{t} S_{m}(A)+M^{\prime}{ }_{t} S_{m} \frac{(B+H)}{t}+\frac{E q^{\prime}{ }_{t}}{t}(C)\right. \\
& \left.+K R S \frac{M^{\prime}{ }_{t}}{t}(D+E+F)-M a t^{\prime}{ }_{0} \frac{(G)}{t}+C I^{\prime}{ }_{t} \times t\right) \\
& t_{\text {ótimo }}=\sqrt{\frac{K R S M^{\prime}{ }_{t}\left(A S_{m}+D+E+F\right)+M^{\prime}{ }_{t} S_{m}(B+H)+E q^{\prime}{ }_{t}(C)-M a t^{\prime}{ }_{0}(G)}{C I^{\prime}{ }_{t}}} \\
& t_{\text {ótimo }}=12,79 \text { meses }
\end{aligned}
$$

\begin{tabular}{|c|c|c|c|c|c|c|c|c|c|c|c|c|}
\hline \multicolumn{13}{|c|}{ RESUMO ORCAMENTÁRIO - CUSTOS VARIÁVEIS } \\
\hline Prazo & 1,00 & 2,00 & 3,00 & 4,00 & 5,00 & 6,00 & 7,00 & 8,00 & 9,00 & 10,00 & 11,00 & 12,00 \\
\hline Custos Diretos & $8.877 .679,41$ & $4.508 .583,11$ & $3.052 .217,68$ & $2.324 .034,97$ & $1.887 .125,34$ & $1.595 .852,25$ & $1.387 .800,05$ & $1.231 .760,89$ & $1.110 .397,11$ & $1.013 .306,08$ & $933.867,96$ & $867.669,53$ \\
\hline Mão de Obra & $9.146 .100,27$ & 4.642.793,55 & $3.141 .691,30$ & $2.391 .140,18$ & $1.940 .809,51$ & $1.640 .589,06$ & $1.426 .145,88$ & $1.265 .313,50$ & $1.140 .221,65$ & $1.040 .148,16$ & $958.269,86$ & $890.037,94$ \\
\hline $\begin{array}{l}\text { Equipamentos } \\
\text { Materiais }\end{array}$ & $(268.420 .86)$ & $(134.210 .43)$ & $(89.473 .62)$ & $(67.105,22)$ & $(53.684 .17)$ & $(44.736 .81)$ & $(38.345,84)$ & 133552611 & $(29824541$ & & & \\
\hline $\begin{array}{l}\text { Materiais } \\
\text { Custos Indiretos }\end{array}$ & $55.872,49$ & $111.744,98$ & $167.617,47$ & $\begin{array}{l}(67.105,22) \\
223.499 .96\end{array}$ & $\begin{array}{l}(53.684,17) \\
279,36245\end{array}$ & $\begin{array}{l}(44 . / 76,81) \\
335,234,94\end{array}$ & $\begin{array}{l}\text { (38.345,84) } \\
391.107 .43\end{array}$ & $\begin{array}{l}(33.552,61) \\
446,9799\end{array}$ & $\begin{array}{l}(29.824,54) \\
5028542\end{array}$ & $\begin{array}{l}(26.842,09) \\
558.724 .90\end{array}$ & $\begin{array}{l}(24.401,90) \\
614.597,39\end{array}$ & $\begin{array}{l}(22.368,41) \\
670,46988\end{array}$ \\
\hline Custos Totais & 8.933.551,90 & 4.620.328,09 & $3.219 .835,15$ & $2.547 .524,93$ & $2.166 .487,79$ & $1.931 .087,19$ & $1.778 .907,48$ & $1.678 .740,81$ & $\begin{array}{r}3.613 .2439,51 \\
\end{array}$ & $\begin{aligned} 1350.927,90 \\
1.572 .030,98\end{aligned}$ & $\begin{array}{r}1.548 .465,35 \\
\end{array}$ & $\begin{array}{r}0.538 .139,41 \\
\end{array}$ \\
\hline Prazo & 13,00 & 14,00 & 15,00 & 16,00 & 17,00 & 18,00 & 19,00 & 20,00 & 21,00 & 22,00 & 23,00 & 24,00 \\
\hline Custos Diretos & $811.655,48$ & $763.643,43$ & $722.032,99$ & $685.623,86$ & $653.498,15$ & $624.941,96$ & $599.391,69$ & $576.396,45$ & $555.591,23$ & $536.677,39$ & $519.408,24$ & $503.578,18$ \\
\hline Mão de Obra & $832.303,24$ & $782.816,35$ & $739.927,72$ & $702.400,16$ & $669.287,61$ & $639.854,23$ & $613.519,11$ & $589.817,49$ & $568.373,17$ & $548.878,34$ & $531.078,71$ & $514.762,38$ \\
\hline Equipamentos & & & & & & - & & & - & & & - \\
\hline Materiais & $(20.647,76)$ & $(19.172,92)$ & $(17.894,72)$ & $(16.776,30)$ & $(15.789,46)$ & $(14.912,27)$ & $(14.127,41)$ & $(13.421,04)$ & $(12.781,95)$ & $(12.200,95)$ & $(11.670,47)$ & $(11.184,20)$ \\
\hline Custos Indiretos & $726.342,37$ & $782.214,86$ & $838.087,35$ & $893.959,84$ & $949.832,33$ & $1.005 .704,82$ & $1.061 .577,31$ & $1.117 .449,80$ & $1.173 .322,29$ & $1.229 .194,78$ & $1.285 .067,27$ & $1.340 .939,76$ \\
\hline Custos Totais & 1.537.997,85 & $1.545 .858,29$ & $1.560 .120,34$ & $1.579 .583,70$ & $1.603 .330,48$ & $1.630 .646,78$ & $1.660 .969,00$ & $1.693 .846,25$ & $1.728 .913,52$ & $1.765 .872,17$ & $1.804 .475,51$ & $1.844 .517,94$ \\
\hline Prazo & 25,00 & 26,00 & 27,00 & 28,00 & 29,00 & 30,00 & 31,00 & 32,00 & 33,00 & 34,00 & 35,00 & 36,00 \\
\hline Custos Diretos & $489.014,52$ & $475.571,15$ & $463.123,58$ & $451.565,13$ & $440.803,80$ & $430.759,90$ & $421.364,00$ & $412.555,34$ & $404.280,53$ & $396.492,48$ & $389.149,46$ & $382.214,39$ \\
\hline Măo de Obra & $499.751,36$ & $485.895,03$ & $473.065,09$ & $461.151,58$ & $450.059,70$ & $439.707,27$ & $430.022,74$ & $420.943,49$ & $412.414,50$ & $404.387,21$ & $396.818,63$ & $389.670,53$ \\
\hline Equipamentos & & & & & & - & & & 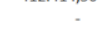 & & & \\
\hline Materiais & $(10.736,83)$ & $(10.323,88)$ & $(9.941,51)$ & $(9.586,46)$ & $(9.255,89)$ & $(8.947,36)$ & $(8.658,74)$ & $(8.388,15)$ & $(8.133,97)$ & $(7.894,73)$ & $(7.669,17)$ & $(7.456,14)$ \\
\hline Custos Indiretos & $1.396 .812,25$ & $1.452 .684,74$ & $1.508 .557,23$ & $1.564 .429,72$ & $1.620 .302,21$ & $1.676 .174,70$ & $\begin{array}{c}1.732 .047,19 \\
\end{array}$ & $\begin{array}{l}1.787 .919,68 \\
\end{array}$ & $1.843 .792,17$ & $1.899 .664,66$ & $1.955 .537,15$ & $2.011 .409,64$ \\
\hline Custos Totais & $1.885 .826,77$ & $1.928 .255,89$ & $1.971 .680,81$ & $2.015 .994,85$ & $2.061 .106,01$ & $2.106 .934,60$ & 2.153.411,19 & $2.200 .475,02$ & $2.248 .072,70$ & $2.296 .157,14$ & $2.344 .686,61$ & $2.393 .624,03$ \\
\hline Prazo & 37,00 & 38,00 & 39,00 & 40,00 & 41,00 & 42,00 & 43,00 & 44,00 & 45,00 & 46,00 & 47,00 & 48,00 \\
\hline Custos Diretos & $375.654,19$ & $369.439,26$ & $363.543,04$ & $357.941,63$ & $352.613,47$ & $347.539,02$ & $342.700,60$ & $338.082,10$ & $333.668,88$ & $329.447,53$ & $325.405,81$ & $321.532,50$ \\
\hline Mão de Obra & $382.908,80$ & $376.502,96$ & $370.425,63$ & $364.652,15$ & $359.160,32$ & $353.930,00$ & $348.942,95$ & $344.182,58$ & $339.633,78$ & $335.282,76$ & $331.116,89$ & $327.124,60$ \\
\hline Equipamentos & - & - & - & - & 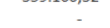 & - & 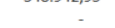 & - & & 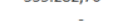 & - & $527.124,00$ \\
\hline Materiais & $(7.254,62)$ & $(7.063,71)$ & $(6.882,59)$ & $(6.710,52)$ & $(6.546,85)$ & $(6.390,97)$ & $(6.242,35)$ & $(6.100,47)$ & $(5.964,91)$ & $(5.835,24)$ & $(5.711,08)$ & $(5.592,10)$ \\
\hline Custos Indiretos & $2.067 .282,13$ & $2.123 .154,62$ & $2.179 .027,11$ & $2.234 .899,60$ & $2.290 .772,09$ & $2.346 .644,58$ & $2.402 .517,07$ & $2.458 .389,56$ & $2.514 .262,05$ & $2.570 .134,54$ & $2.626 .007,03$ & $2.681 .879,52$ \\
\hline Custos Totais & 2.442.936,32 & $2.492 .593,88$ & $2.542 .570,15$ & $2.592 .841,23$ & 2.643.385,56 & $2.694 .183,60$ & 2.745.217,67 & $\begin{array}{l}2.796 .471,66 \\
\end{array}$ & 2.847.930,93 & $2.899 .582,07$ & 2.951.412,84 & $3.003 .412,02$ \\
\hline
\end{tabular}

Abaixo, segue a planilha de cálculo utilizada para validação de todo o modelo e elaboração dos gráficos.

Figura 19 - Planilha de Cálculo dos Custos Variáveis

\subsubsection{ESTUDO DA CURVA DE CUSTOS VARIÁVEIS}

O Gráfico 19 representa a curva dos custos variáveis para o projeto estudado. Nesta curva, é possível observar o comportamento inversamente proporcional ao prazo dos custos diretos, o comportamento diretamente proporcional ao prazo dos custos indiretos e o comportamento parabólico da curva final resultante da adição dos custos diretos e indiretos, além do ponto onde o prazo é ótimo para o projeto.

Analisando a curva juntamente com toda a explanação de suas características, conforme abordado no Item 3.1.1 e em seus subitens, fica perceptível, pela médiaalta inclinação da curva dos custos resultante, que este projeto tem algum potencial de redução de custos caso haja alteração nos prazos. Ao final, para este tipo de 
projeto, a resposta final de análise do item é que ela deve ser continuada nos Itens $6^{\circ}$ e $7^{\circ}$, pois o projeto gera potenciais ganhos com a sua redução de prazo.

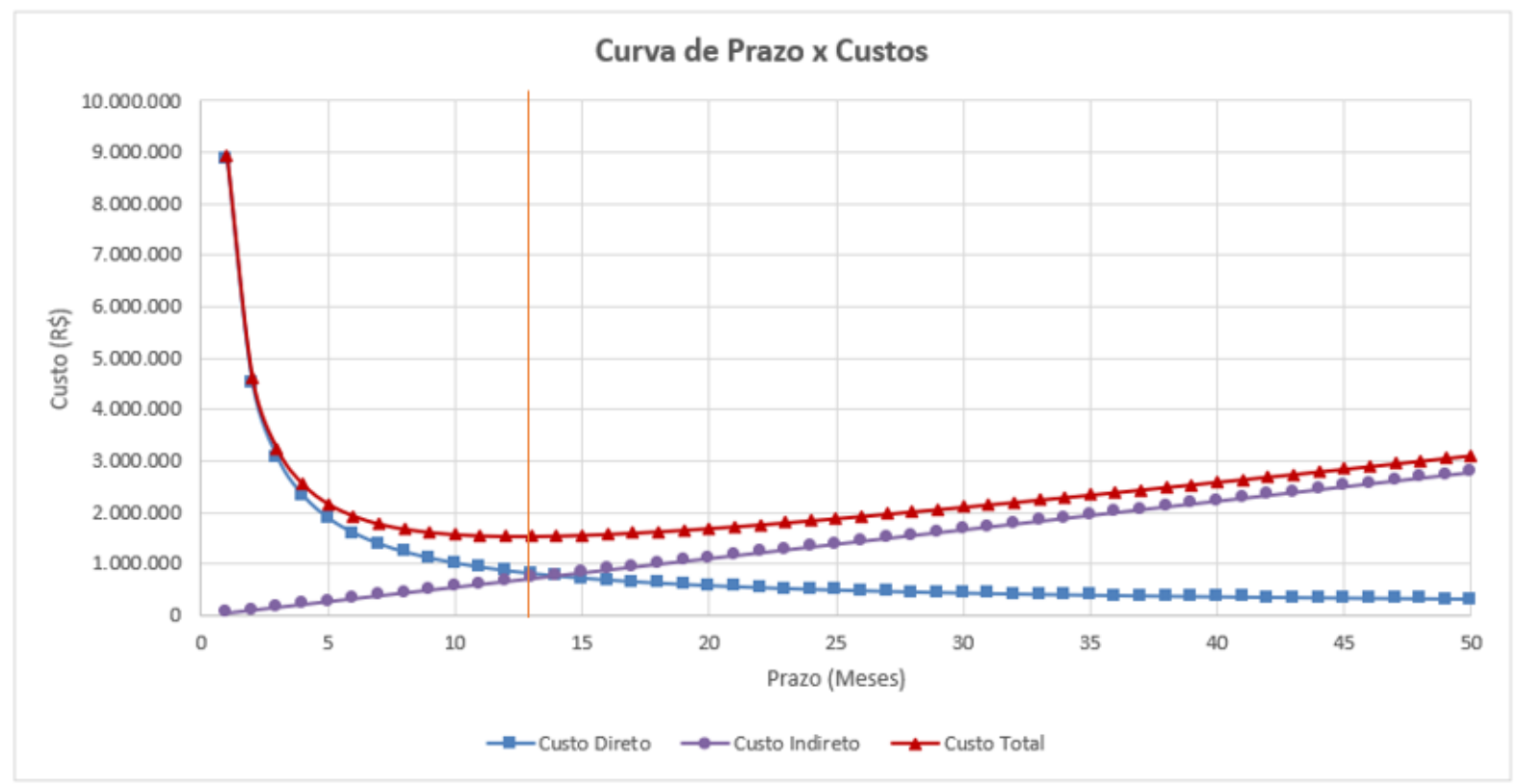

Gráfico 19 - Curva de prazo ótimo - Condomínio de casas

\subsubsection{VERIFICAÇÃO SE O PRAZO ESTIMADO INICIALMENTE É MAIOR OU MENOR QUE O PRAZO ÓTIMO DETERMINADO}

Conforme abordado anteriormente, no caso da identificação de um bom potencial de economia com as reduções de prazo, cabe ao orçamentista identificar se o prazo inicialmente concebido para o projeto é maior ou menor que o prazo ótimo calculado pela Equação (18) e tomar as decisões, conforme abordado no Item 3.1.4.

Em uma análise detalhada deste item, considerando que o prazo ótimo obtido foi de 13 meses e que o prazo inicialmente concebido para o projeto era de 41 meses, conforme o Gráfico 20. Desta maneira, é muito válido o reestudo dos cronogramas do projeto a fim de encontrar o menor prazo possível até o limite do prazo ótimo em ordem de encontrar o menor custo total, conforme o próximo item.

\subsubsection{RECÁLCULO E DETERMINAÇÃO DO CRONOGRAMA A PONTO-LIMITE DE ACORDO COM A DEFINIÇẪO ADOTADA NA ETAPA ANTERIOR}

Neste caso em específico, fazendo os estudos de maior redução de prazo possível, considerando maiores equipes de trabalho, e não considerando nenhuma modificação tecnológica dos serviços, apenas o aproveitamento dos seus limites máximos, o cronograma se reduziu para 13 meses, coincidindo, assim, com o prazo ótimo do projeto. Neste caso, tal redução foi possível pela característica horizontal 
do projeto, em que múltiplas tarefas podem ser executadas simultaneamente sem restrição de predecessoras.

A partir do Gráfico 20, é possível observar a região azul, região onde pode ocorrer a redução do prazo e a consecutiva redução dos custos totais, sem a necessidade de alteração da tecnologia construtiva.

O conhecimento das zonas do projeto é extremamente importante, uma vez que os orçamentistas, detendo estas informações, além do conhecimento da região e dos valores de economia de custo na mudança do prazo, possuem disponível a informação para analisar os custos de economia de prazo versus uma possível troca de tecnologia construtiva, que normalmente acresceria os custos. Neste caso em específico, como é possível a redução do prazo do projeto ao prazo ótimo, os cálculos da inovação e as trocas de tecnologias não se fazem necessários.

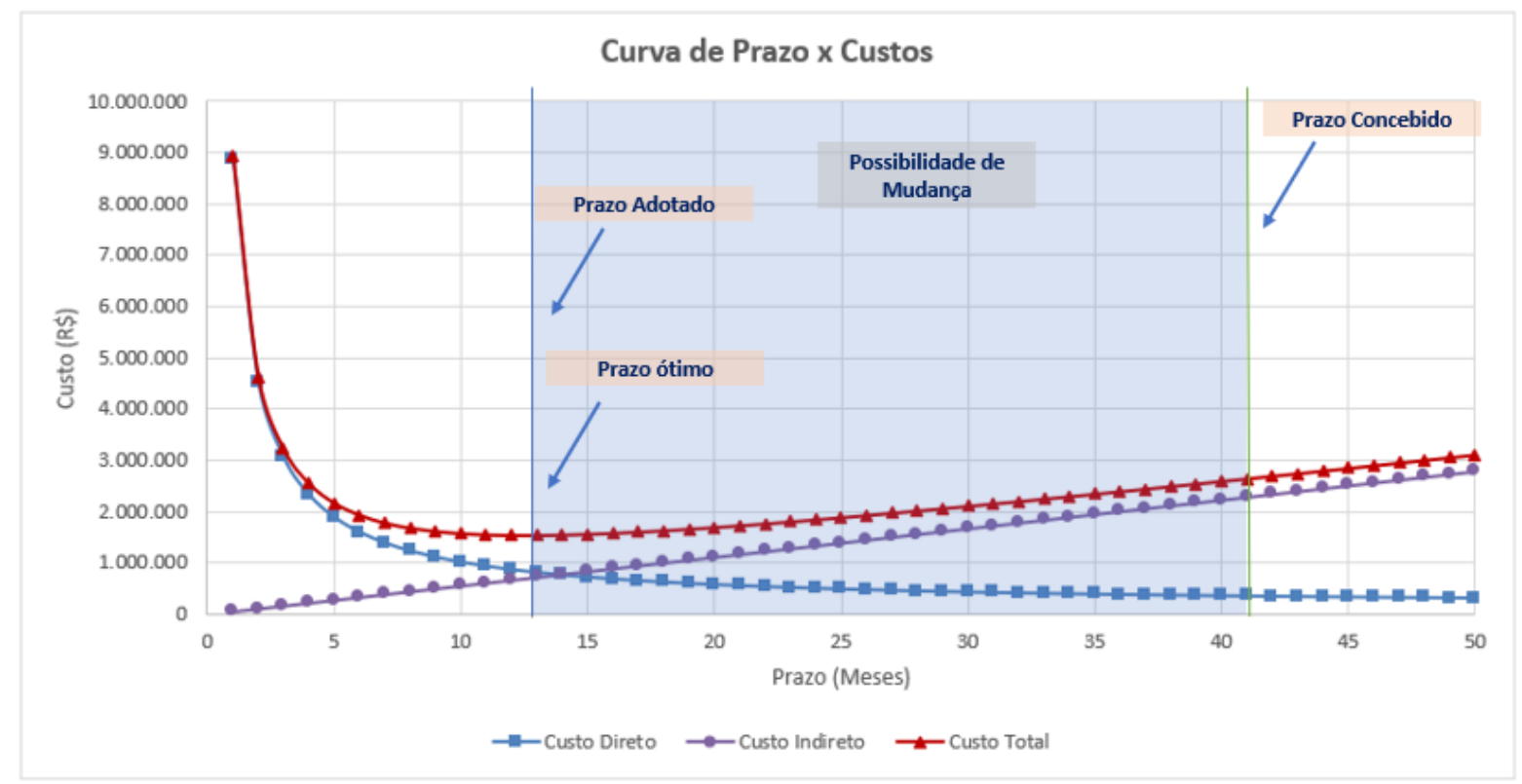

Gráfico 20 - Curva de prazo ótimo - Condomínio de casas (zonas de projeto)

\subsubsection{CÁLCULO FINAL DO POTENCIAL DE ECONOMIA UTILIZANDO PARÂMETROS DO CRONOGRAMA RECALCULADO}

Uma vez estabelecido o novo prazo de 13 meses, pode ser feito o cálculo final do potencial de economia a ser gerada pela redução de prazos. Tal valor foi determinado pelo uso da Equação (19). 


$$
\begin{aligned}
\Delta C A_{t_{\text {ótimo }}}=( & K R S \frac{M^{\prime}{ }_{t}}{t} S_{m}(A)+M^{\prime}{ }_{t} S_{m} \frac{(B+H)}{t}+\frac{E q^{\prime}{ }_{t}}{t}(C) \\
& \left.+K R S \frac{M^{\prime}{ }_{t}}{t}(D+E+F)-M a t^{\prime}{ }_{0} \frac{(G)}{t}+C I^{\prime}{ }_{t} \times t\right) \\
& -\left(K R S \frac{M^{\prime}{ }_{t}}{t_{\text {ótimo }}} S_{m}(A)+M^{\prime}{ }_{t} S_{m} \frac{(B+H)}{t_{\text {ótimo }}}+\frac{E q^{\prime}{ }_{t}}{t_{\text {ótimo }}}(C)\right. \\
& \left.+K R S \frac{M^{\prime}{ }_{t}}{t_{\text {ótimo }}}(D+E+F)-M a t^{\prime}{ }_{0} \frac{(G)}{t_{\text {ótimo }}}+C I^{\prime}{ }_{t} \times t_{\text {ótimo }}\right)
\end{aligned}
$$

Neste caso, ao comparar os custos variáveis, percebe-se que o projeto durando 41 meses, os custos variáveis totalizaram aproximadamente $R \$ 2,6 \mathrm{MM}$. Com a redução de prazo de 28 meses, o projeto ficaria com 13 meses e teria um custo variável de aproximadamente $R \$ 1,5 \mathrm{MM}$, gerando uma economia aproximada de $\mathrm{R} \$ 1,1 \mathrm{MM}$, que representa um desconto no preço-base do negócio, que é de $\mathrm{R} \$$ 11,6 MM, de 9,7\%, conforme o Quadro 70.

Quadro 70 - Cálculo da economia gerada pelo método

\begin{tabular}{|l|c|} 
Economia Gerada & $\mathbf{9 , 7 \%}$ \\
\hline Custos variáveis - 41 meses & $\mathrm{R} \$ 2.643 .385,56$ \\
Custos variáveis - 13 meses & $\mathrm{R} \$ 1.537 .997,85$ \\
\hline Ganhos & $\mathbf{R} \$ \mathbf{1 . 1 0 5 . 3 8 7 , 7 1}$ \\
\hline
\end{tabular}

A partir dos cálculos efetuados acima, ficam perceptíveis as vantagens do uso do método para alguns tipos de projeto. Neste caso em específico, uma ordem de economia de $9,7 \%$ sobre o preço-base das estimativas iniciais do projeto. Este é um valor que pode fazer com que a empresa ganhe um elevado nível competitivo nas concorrências ou nos negócios.

Conforme abordado no início do trabalho, este método deve ser utilizado para um cálculo aproximado do nível de redução de custos possível e serve como uma ferramenta para direcionar os orçamentistas no estudo aprofundado do projeto em relação ao prazo a ser adotado. Muitas vezes, questões secundárias, como os critérios de desembolso do cliente ou a impossibilidade de redução tão grande de prazo prevista em edital, podem fazer com que o novo prazo a ser adotado seja obrigatoriamente diferente. Este caso representa bem a última sentença descrita, pois, por se tratar de um empreendimento financiado por meios privados, ele depende dos aportes da empresa ou do plano de venda, entretanto, com as informações disponibilizadas em mãos, a empresa pode calcular o que é mais vantajoso para ela.

Todo este estudo sob o ponto de vista do investidor e proprietário pode ser abordado no item 3.1.3 deste trabalho. Os desembolsos financeiros, porém, não serão detalhados neste exemplo por não estarem no enfoque do trabalho. 
Ao final, optou-se por adotar a solução mais econômica de equalizar o prazo do projeto ao prazo ótimo calculado. Abaixo, segue o cronograma macro do empreendimento contendo o prazo inicialmente estabelecido e $o$ adotado.

Ressalta-se, entretanto, que o prazo ótimo de 13 meses estimado como viável, foi balizado na experiência menos substancial do autor, sendo passível de questionamento. 


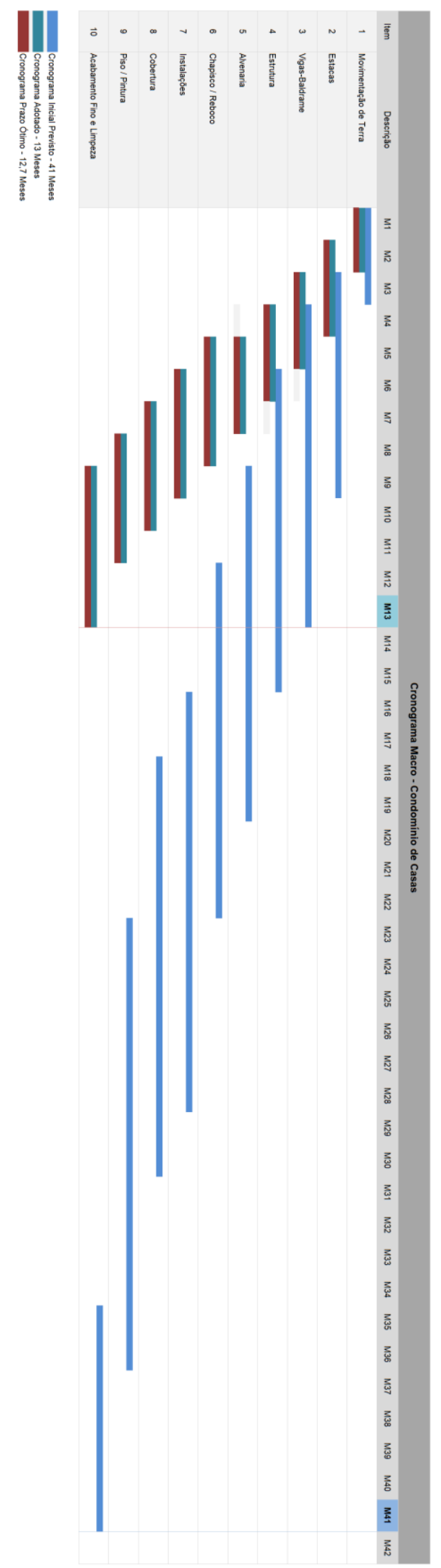

Figura 20 - Cronograma Prazo Previsto $\times$ Adotado = Prazo Ótimo 
Independentemente das questões acima levantadas, após todo este estudo, é fundamental que seja feito novamente o orçamento detalhado para o cálculo do valor real do projeto. 


\section{CONCLUSÃO E FUTUROS DESENVOLVIMENTOS}

\subsection{CONCLUSÃO}

A realidade dos orçamentos e do planejamento de obras no Brasil é muito complexa. Há grandes erros em estimativas de custos e prazos. Atrasos, prejuízos e aditivos são recorrentes e colaboram com problemas institucionais. Há falta de confiabilidade nas margens de lucro contratuais e nas projeções de investimento, dificultando o relacionamento com investidores e a captação de recursos. Há gastos excessivos com mão de obra, materiais, equipamentos e custos indiretos. Além de tudo, há um atraso em comparação com outras indústrias que, de maneira geral, conseguem abordar tais problemas com maior confiabilidade e de maneira mais científica e técnica.

A mudança desta realidade demanda processos inovativos. Muitos processos têm sido desenvolvidos e aplicados; a adoção do Lean Construction e do BIM - Building Information Modeling são dois exemplos fortes. Este trabalho também é um exemplo de processo de inovação e pretende ajudar a mitigar as problemáticas abordadas acima.

Após toda a revisão bibliográfica das metodologias existentes e de toda a explicação, desenvolvimento e aplicação do método, constata-se que ele permite que a empresa ou os orçamentistas tenham um ponto de partida para a determinação dos prazos em seus projetos na questão da análise de trade-off entre tempo e custos. Além disso, o método também possibilita uma análise e um estudo mais detalhados sobre o comportamento do prazo e dos custos nos projetos, a partir da geração da curva de relacionamento entre eles, dado pelas equações do método.

A aplicação do método se mostrou extremamente simples (após a obtenção dos fatores da equação) e conseguiu gerar resultados interessantes no que tange a redução de custos para dois tipos distintos de obra, ressalta-se novamente que o segundo caso (empreendimento imobiliário) tem papel menos relevante neste trabalho vendo a menor experiência do autor nesta área. Vale observar um resultado interessante obtido para ambos os casos, a redução máxima de custos decorrente da redução do prazo original para o prazo de tempo ótimo gerou em torno de $10 \%$ de economia.

É importante também salientar as fragilidades do método, primeiro, para o seu uso eficaz, é necessário que a empresa ou os orçamentistas tenham minimamente recursos tecnológicos de orçamentos, como softwares de orçamento e programas de gerenciamento de dados, o trabalho para a obtenção de todos os dados é bastante grande. Outro ponto importante é o fato de o método não calcular valores exatos, devido ao fato de ser balizado em premissas e em médias de diversos parâmetros, resultando, assim, não numa ferramenta de cálculo acurada para o orçamento final, mas, sim, num mecanismo de identificação do relacionamento entre prazos e custos juntamente com a sua potencialidade de geração de economias ou de perdas financeiras.

No aspecto das fragilidades, também pode-se citar o da determinação dos 16 fatores que compõem a equação para determinação do prazo ótimo, sua grande maioria 
teve pouco rigor científico e se balizaram em impressões e percepções geradas da vivência prática e profissional do autor, estando sujeitos à equívocos. Outro aspecto que vale a pena ser citado, é o da composição da equipe indireta da obra na abordagem matemática da equação, a qual foi considerada sempre como constante independentemente do prazo da obra, mas ao se reduzir de maneira significativa o prazo do projeto, esta poderia ser modificada também.

Apesar de todos os fatores abordados acima, diferentemente dos outros métodos encontrados nas revisões bibliográficas, que eram muito complexos ou apenas explicavam a conceituação do problema, o método atinge os objetivos inicialmente propostos de maneira sólida, pois está estruturado em fundamentação matemática.

Por fim, conclui-se que o método é uma inovação, é uma ferramenta de simples uso e possui enorme potencial de desenvolvimento e aplicabilidade para o setor da Construção Civil. Destacam-se aqui as duas vertentes com maior potencial:

A possibilidade de as empresas mensurarem financeiramente a zona de inovação tecnológica e o potencial financeiro que o investimento em novas tecnologias teria nos casos em que o prazo ótimo não pode ser atingido, devido ao caminho crítico do projeto, conseguindo, assim, mensurar o custo de oportunidade para tais investimentos. Muitas vezes, as empresas não investem em inovações por acharem os custos altos, mas, como pôde ser exemplificado pelo método, muitas vezes, mesmo investindo em tecnologias mais caras, a empresa ainda poderia ter melhores resultados gerados pela redução dos prazos.

A outra vertente seria uma adoção do uso deste método pelo setor público em seus estudos dos editais de projetos a serem licitados. As reduções de prazos poderiam gerar grandes economias não só para as empresas contratadas para a execução dos serviços, mas também para os próprios órgãos públicos, fato que beneficiaria a população como um todo.

\subsection{FUTUROS DESENVOLVIMENTOS}

O método desenvolvido para este trabalho caracteriza-se pela facilidade de, entretanto faz uso de muitas aproximações nos cálculos de valores de mão de obra, equipamentos, entre outros. Mesmo assim, possibilita, com uma boa acurácia, o que se propõe, que é determinar as variabilidades dos custos em função dos prazos estabelecidos no projeto.

Hoje, com a imensa disponibilidade de softwares no mercado, dentre eles se inclui o mais recorrente uso de tecnologias balizadas no BIM - Building Information Modeling para projetos, a aplicação dos equacionamentos do método via softwares aumentaria a precisão com a redução das aproximações e faria o modelo muito mais robusto. Este é um dos futuros desenvolvimentos deste trabalho que, definitivamente, pode ser colocado em prática.

O fato de o método proposto ter algumas limitações decorrentes do emprego da percepção profissional do autor gera uma oportunidade, pode ser desenvolvido um trabalho para o aperfeiçoamento da obtenção dos 16 fatores que compõem a equação do prazo ótimo com maior rigor científico, culminando no reforço da credibilidade do uso do método. O trabalho seria desenvolvido no sentido da 
obtenção destes fatores realizando checagens e pesquisas científicas de como cada um dos fatores realmente variam com o prazo.

Outro futuro desenvolvimento do trabalho relaciona-se à realização de múltiplas iterações dos 16 fatores da equação do prazo ótimo visando buscar superfícies ou regiões de iterações que possibilitariam uma melhor análise de como o prazo dos projetos responde a cada um dos fatores apontados na equação. 


\section{REFERÊNCIAS}

AGYEI, W. Project Planning and Scheduling Using PERT and CPM Techniques With Linear Programming: Case Study. International Journal of Scientific \& Technology Research, v. 4, n. 08, p. 222-227, 2015.

CÂMARA BRASILEIRA DA INDÚSTRIA DA CONSTRUÇÃO. Banco de Dados CBIC. Disponível em: <http://www.cbicdados.com.br/menu/pib-e-investimento/pibbrasil-e-construcao-civil>. Acesso em: 9 jul. 2018.

CAIRE, Elaine. A história da origem da curva normal. 2013. 109 f. Dissertação (mestrado) - Universidade Estadual Paulista Júlio de Mesquita Filho, Instituto de Geociências e Ciências Exatas, 2013.

CHASSIAKOS, Athanasios P; ASCE, A M; SAKELLAROPOULOS, Serafim P. Time-Cost Optimization of Construction Projects with Generalized Activity Constraints. v. 131, n. October, p. 1115-1124, 2005.

CONTADOR, José Celso. Gestão de operações: a engenharia de produção a serviço da modernização da empresa. São Paulo: Editora Blucher, 2010.

FEDERAL RESERVE BANK OF ST. LOUIS. Value Added by Private Industries:

Construction as a Percentage of GDP. Disponível em:

<https://fred.stlouisfed.org/series/VAPGDPC>. Acesso em: 9 jul. 2018.

FENG, C.-W.; LIU, L.; BURNS, S. A. Using Genetic Algorithms to Solve Construction TimeCost Trade-Off Problems. Journal of Computing in Civil Engineering, v. 11, n. 3, p. 184189, 1997.

FENG, C.-W.; LIU, L.; BURNS, S. A. Stochastic Construction Time-Cost Trade-Off Analysis. Journal of Computing in Civil Engineering, v. 14, n. 2, p. 117-126, 2000.

FULKERSON, D. R. A network flow computation for project cost curve. Management Science, v. 7, n. 2, 1961.

GADELHA, Luiz Gonzaga da Costa. Orçamento na costrução pesada orçamento e programação de barragem de terra. Recife: Editora do Autor, 2011.

GADELHA, Luiz Gonzaga da Costa. Orçamento e programação de pontes em balanços sucessivos. Recife: Editora do Autor, 2009.

HARI, S. Comparative Study of Time-Cost Optimization. International Journal of Civil Engineering and Technology, v. 8, n. 4, p. 659-663, 2017.

HEGAZY, Tarek. Optimization of construction time - cost trade-off. 1999.

HIRSCHFELD, Henrique. Planejamento com PERT-CPM e análise do desempenho: método manual e por computadores eletrônicos aplicados a todos os fins, construção civil, marketing etc. São Paulo: Editora Atlas, 1978.

KLANŠEK, U.; PŠUNDER, M. Cost Optimization of Time Schedules for Project

Management. Economic Research-Ekonomska Istraživanja, v. 23, n. 4, p. 22-36, 2010.

KELLY, É. V. (2009). Crash with confidence. Paper presented at PMI® Global Congress 2009 - North America, Orlando, FL. Newtown Square, PA: Project Management Institute. 
MATTOS, Aldo Dórea. Como preparar orçamentos de obras: dicas para orçamentistas, estudos de caso, exemplos. São Paulo: Editora Pini, 2006.

MATTOS, Aldo Dórea. Planejamento e Controle de Obras. São Paulo: Editora Pini, 2010. MEREDITH, J.R., MANTEL, S.J., SHAFER, S. M. Project Management: A Managerial Approach. Ninth edit ed. New York: [s.n.].

Paliari, José Carlos. Metodologia para coleta e análise de informações sobre consumo e perdas de materiais e componentes nos canteiros de obras de edifícios / J.C. Paliari, U.E.L. de Souza. São Paulo: EPUSP, 1999.

PHILIPPS JR., DESSOUKY, M. I. Solving the project management time/cost trade-off problem using minimal cost concept. Management Science, v. 24, n. 4, 1977.

PROJECT MANAGEMENT INSTITUTE - PMI. A Guide to the Project Management Body of Knowledge (PMBOK® Guide). $4^{\text {a }}$ Edição ed. Pennsylvania: [s.n.].

THE WORLD BANK. GDP (current US\$) | Data. Disponível em:

$<$ https://data.worldbank.org/indicator/NY.GDP.MKTP.CD?end=2017\&start=2000>. Acesso em: 9 jul. 2018.

TCPO - Tabelas de Composições de Preços para Orçamentos - 13ª Edição -

São Paulo - Editora PINI Ltda., 2008.

TISAKA, Maçahiko. Orçamento na construção civil: consultoria, projeto e execução. São Paulo: Editora Pini, 2006.

TRIVEDI, M. K.; NAMDEV, S. Use of optimization techniques in time-cost trade off ( TCT ) in civil construction : An Overview. International Journal of Civil Engineering and

Mechanics, v. 2, n. 1, p. 1-13, 2015.

TUFEKCI, S. A flow preserving algorithm for the time/cost trade-off problem, IEE Transactions, 1982.

YIN, Robert K. Estudos de caso: planejamento e métodos. Porto Alegre: Editora Bookman, 2005. 


\section{APÊNDICE A}

Abaixo, seguem algumas das composições de serviços utilizadas para a obra da Ponte de 1,6 km.

Quadro 71 - Composição de serviço - Aço CA-50

\begin{tabular}{|c|c|c|c|c|}
\hline \multicolumn{5}{|c|}{ Planilha de composição de custo unitário } \\
\hline \multicolumn{3}{|l|}{ Projeto PONTE 1,6 Km } & & $12 / 2017$ \\
\hline \multicolumn{4}{|c|}{ COMPOSIÇÃO (CÓDIGO + DESCRIÇÃO) } & UNID. \\
\hline \multicolumn{4}{|c|}{ Fornecimento, preparo e colocação formas aço CA-50 } & KG \\
\hline $\begin{array}{l}\text { RECURSOS DA COMPOSIÇÃO } \\
\text { (CÓDIGO + DESCRIÇÃO) }\end{array}$ & UNID. & COEF. & VALOR UNITÁRIO & VALOR PARCIAL \\
\hline \multicolumn{5}{|c|}{ Aço CA-50 - bitola média - Cortado e } \\
\hline Arame recozido & KG & 0,020000 & 6,10 & 0,12 \\
\hline Montagem e instalação de armação & KG & 1,000000 & 1,38 & 1,38 \\
\hline Aço CA-50 - bitola média & KG & 0,206000 & 2,40 & 0,49 \\
\hline Grupo: E - MATERIAIS & & & & 4,29 \\
\hline CUSTO DIRETO: & & & & 4,29 \\
\hline $\mathrm{BDI}(0 \%)$ & & & & 0,00 \\
\hline TOTAL (CUSTO DIRETO + BDI) & & & & 4,29 \\
\hline
\end{tabular}

Quadro 72 - Composição de serviço - Lançamento de pré-lajes

\begin{tabular}{|c|c|c|c|c|}
\hline \multicolumn{5}{|c|}{ Planilha de composição de custo unitário } \\
\hline \multicolumn{3}{|l|}{ Projeto PONTE 1,6 Km } & & $12 / 2017$ \\
\hline \multicolumn{4}{|c|}{ COMPOSIÇÃO (CÓDIGO + DESCRIÇÃO) } & UNID. \\
\hline \multicolumn{4}{|c|}{ Transporte, lançamento e posicionamento de pré-lajes $165 \mathrm{~kg}$} & UN \\
\hline $\begin{array}{l}\text { RECURSOS DA COMPOSIÇÃO } \\
\text { (CÓDIGO + DESCRIÇÃO) }\end{array}$ & UNID. & COEF. & VALOR UNITÁRIO & VALOR PARCIAL \\
\hline Ferramentas & $\%$ & 3,0000 & 0,05 & 0,15 \\
\hline Caminhão guindauto 40T & $\mathrm{H}$ & 0,1327 & 111,21 & 14,76 \\
\hline Grupo: A - EQUIPAMENTO & & & & 14,91 \\
\hline Custo agregado à mão de obra & $\mathrm{H}$ & 0,7160 & 5,10 & 3,65 \\
\hline
\end{tabular}




\begin{tabular}{|lrrrr|}
\hline Encargos Sociais - Produção Folha & \multicolumn{3}{r|}{} \\
D - Contribuições Mensais & $\%$ & 125,000000 & 0,05 & 6,38 \\
Pedreiro & H & 0,233500 & 7,03 & 1,64 \\
Encarregado Civil & H & 0,015567 & 25,09 & 0,39 \\
Ajudante (apoio ao oficial) & H & 0,467000 & 6,57 & 3,07 \\
Grupo: B - MÃO DE OBRA & & & 15,13 \\
& & & 30,04 \\
\hline CUSTO DIRETO: & & & 0,00 \\
\hline BDI (O\%) & & & 30,04 \\
\hline TOTAL (CUSTO DIRETO + BDI)
\end{tabular}

Quadro 73 - Composição de serviço - Forma metálica

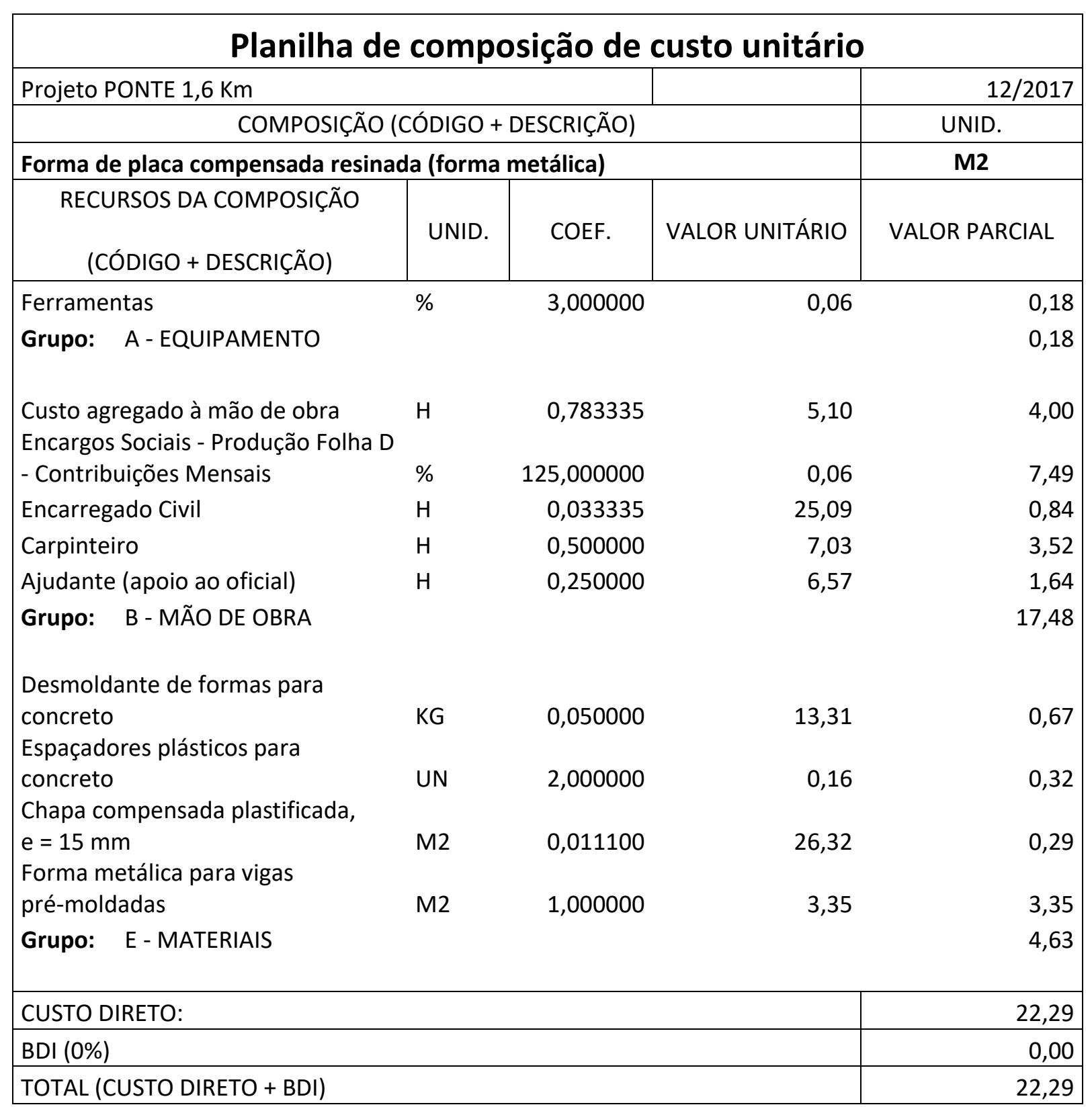


Quadro 74 - Composição de serviço - Concreto $40 \mathrm{Mpa}$

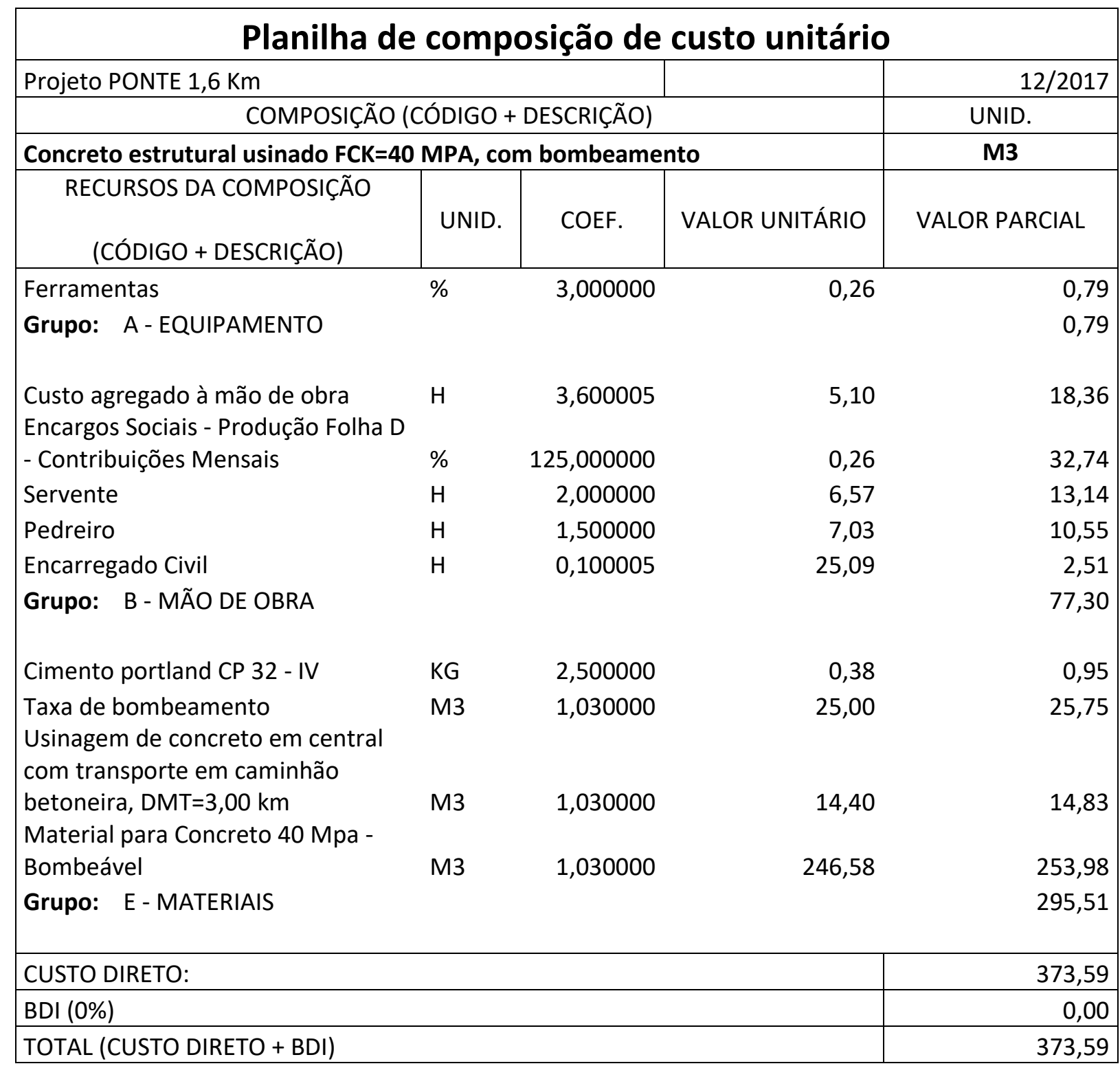




\section{APÊNDICE B}

Abaixo, segue o cronograma mostrando o caminho crítico e a rede de etapas da Ponte de 1,6 km.

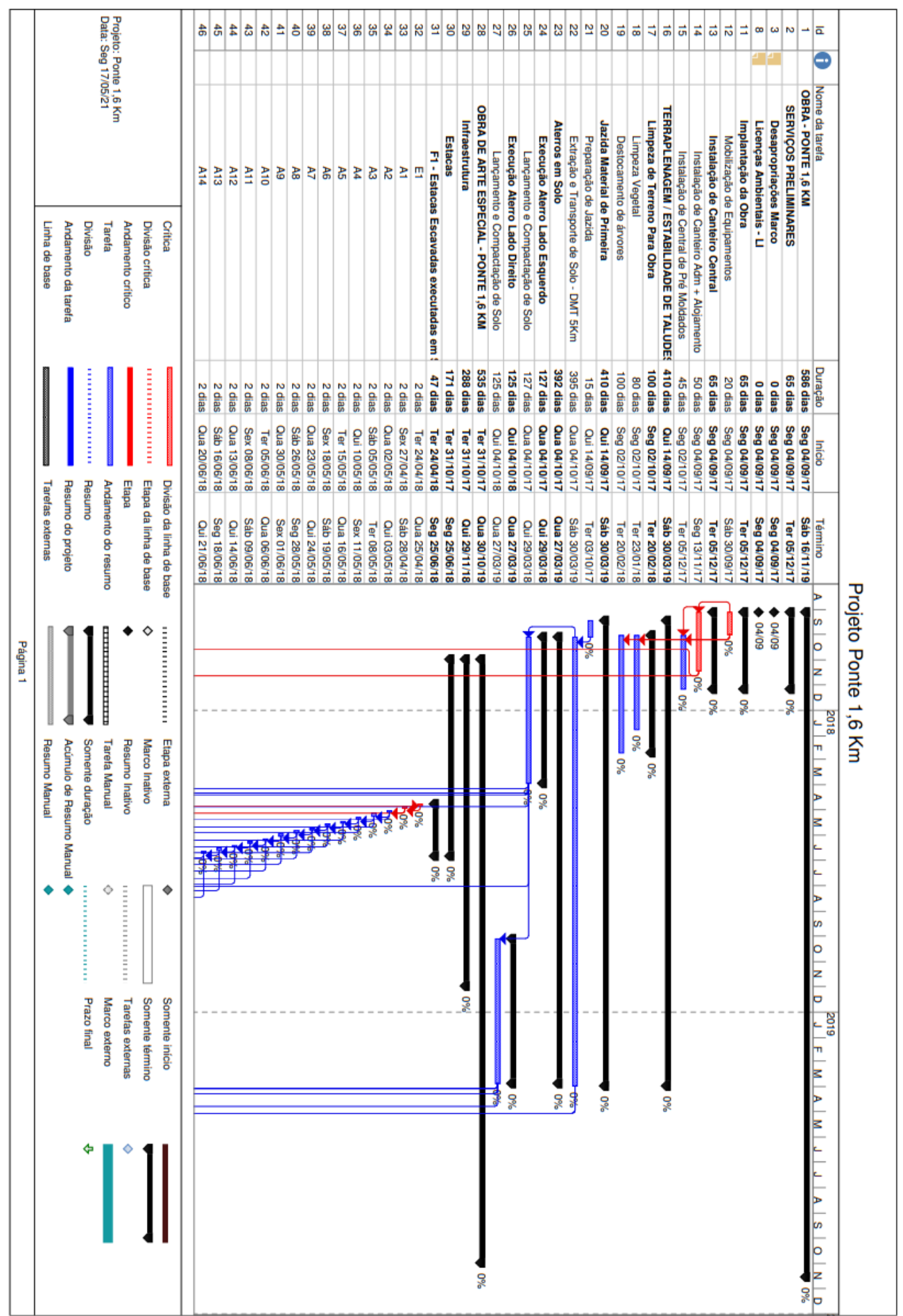

Figura 21 - Cronograma Ponte 1,6 Km 


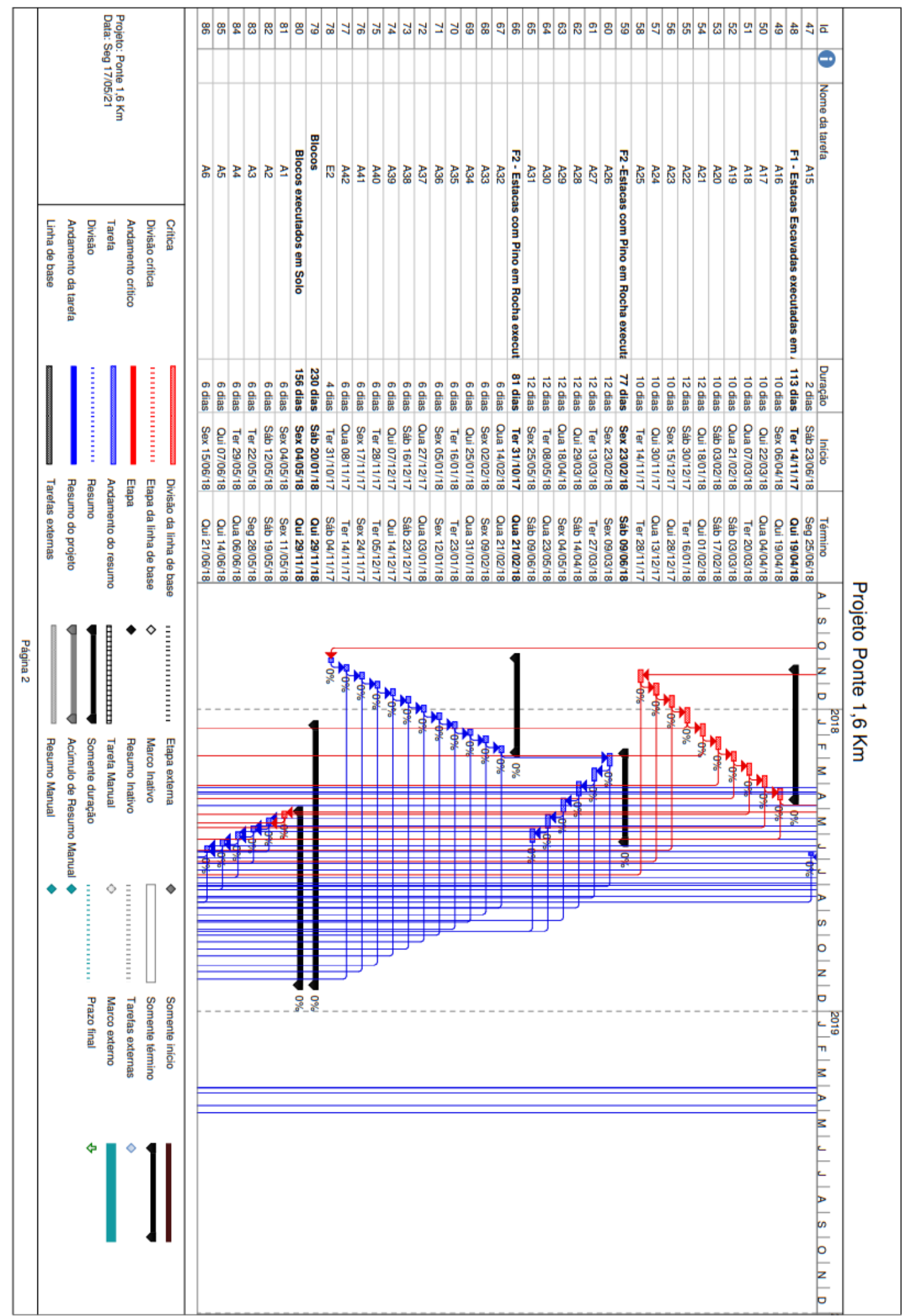

Figura 22 - Cronograma Ponte 1,6 Km 


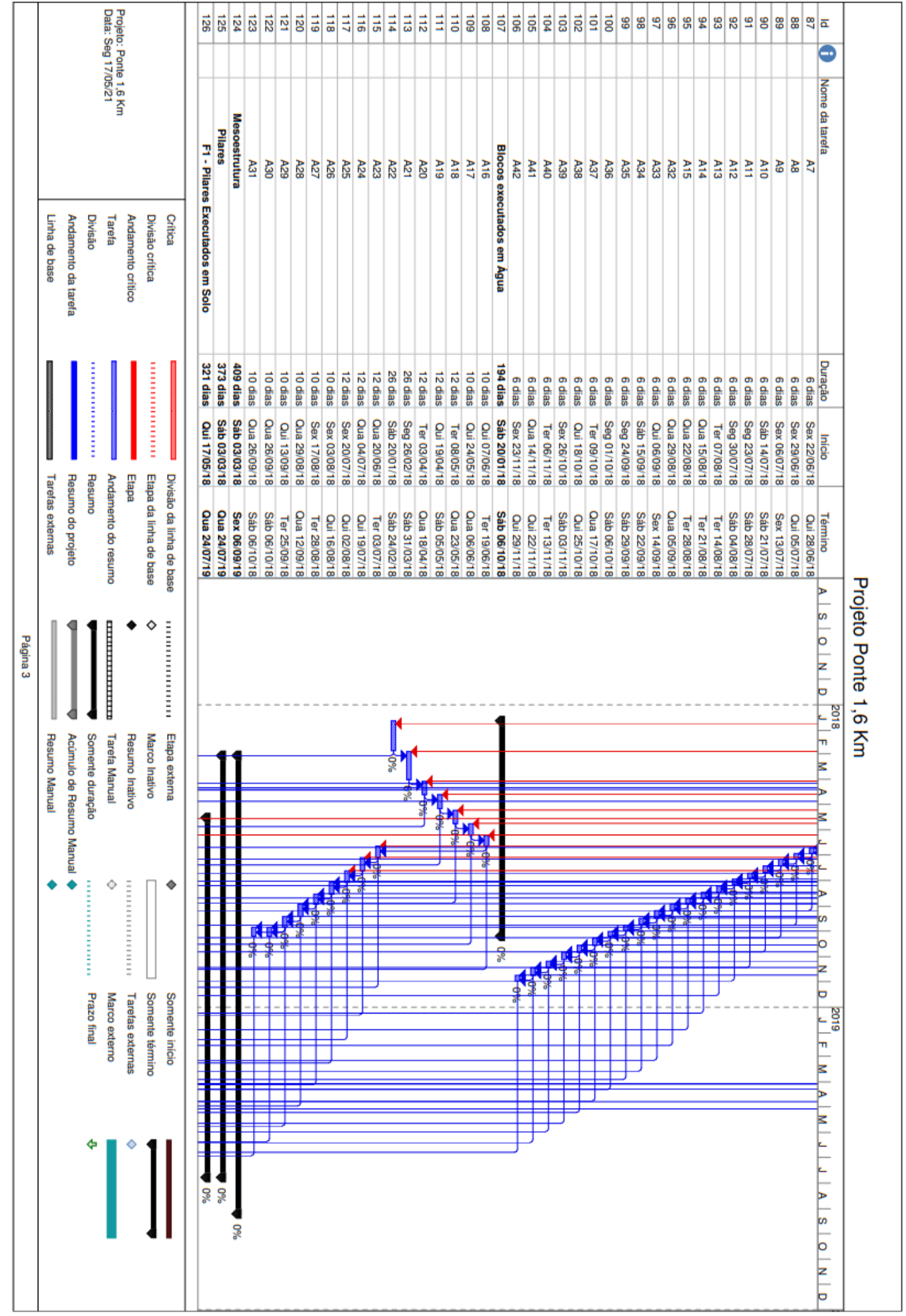

Figura 23 - Cronograma Ponte 1,6 Km 


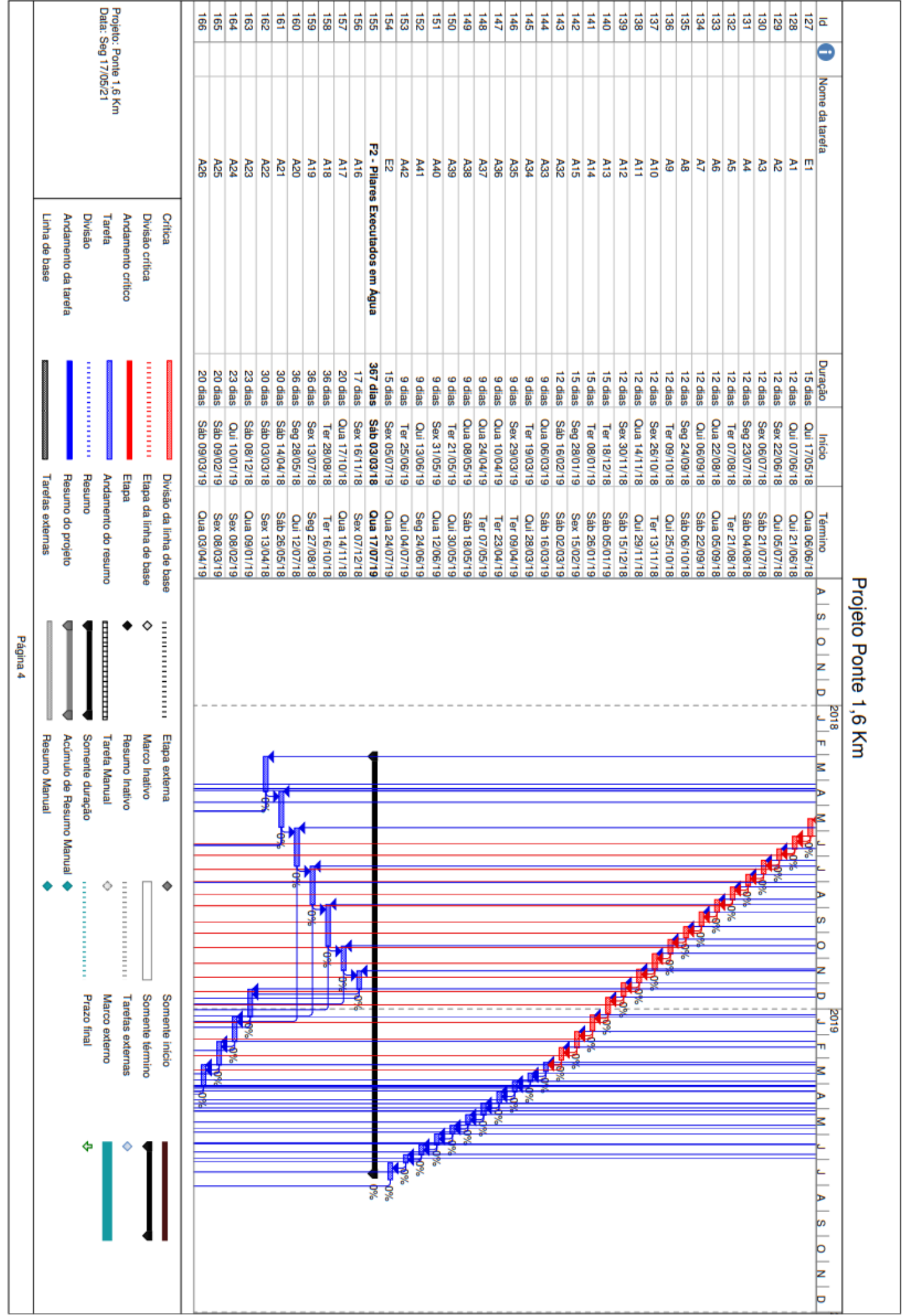

Figura 24 - Cronograma Ponte 1,6 Km 


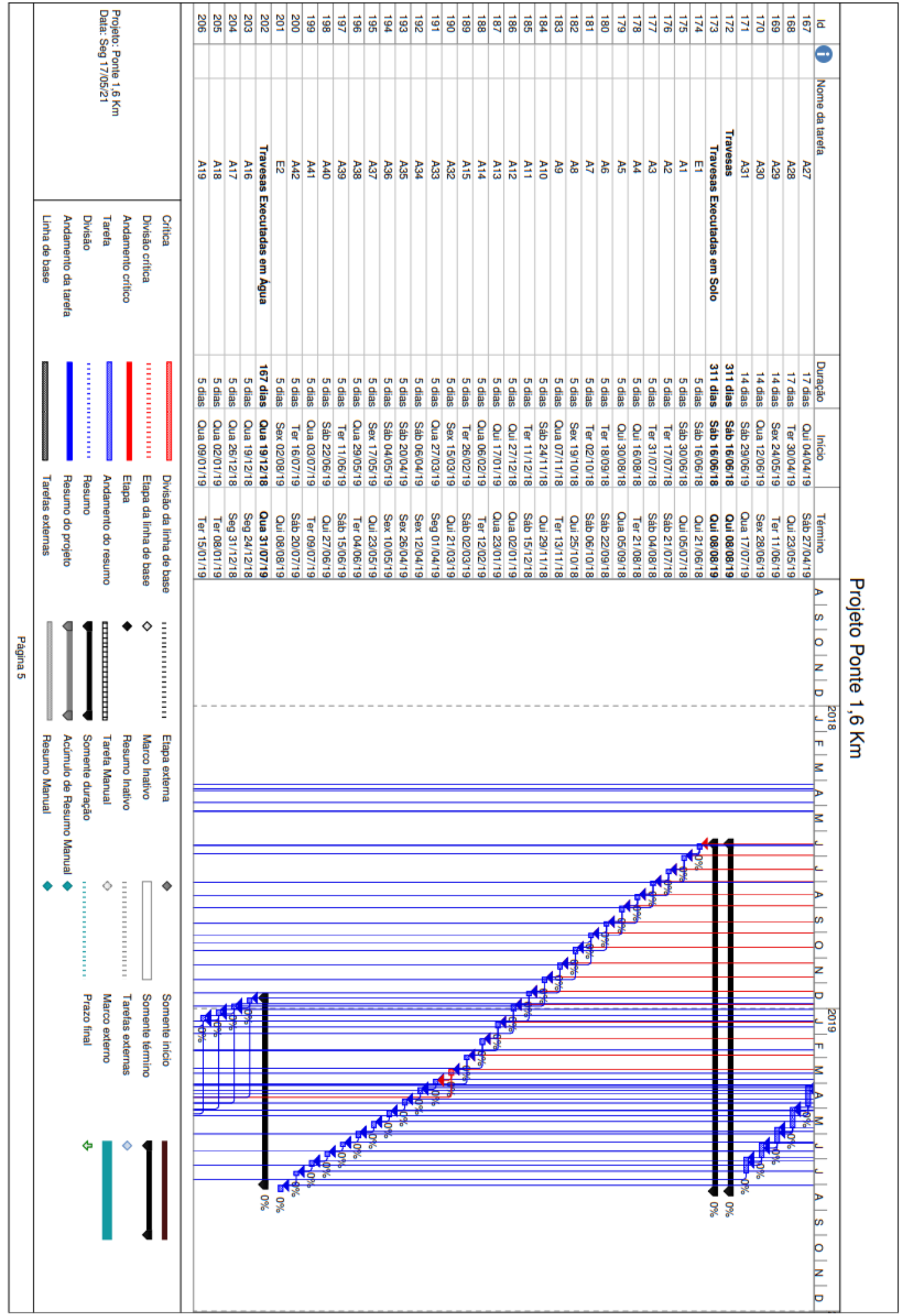

Figura 25 - Cronograma Ponte 1,6 Km 


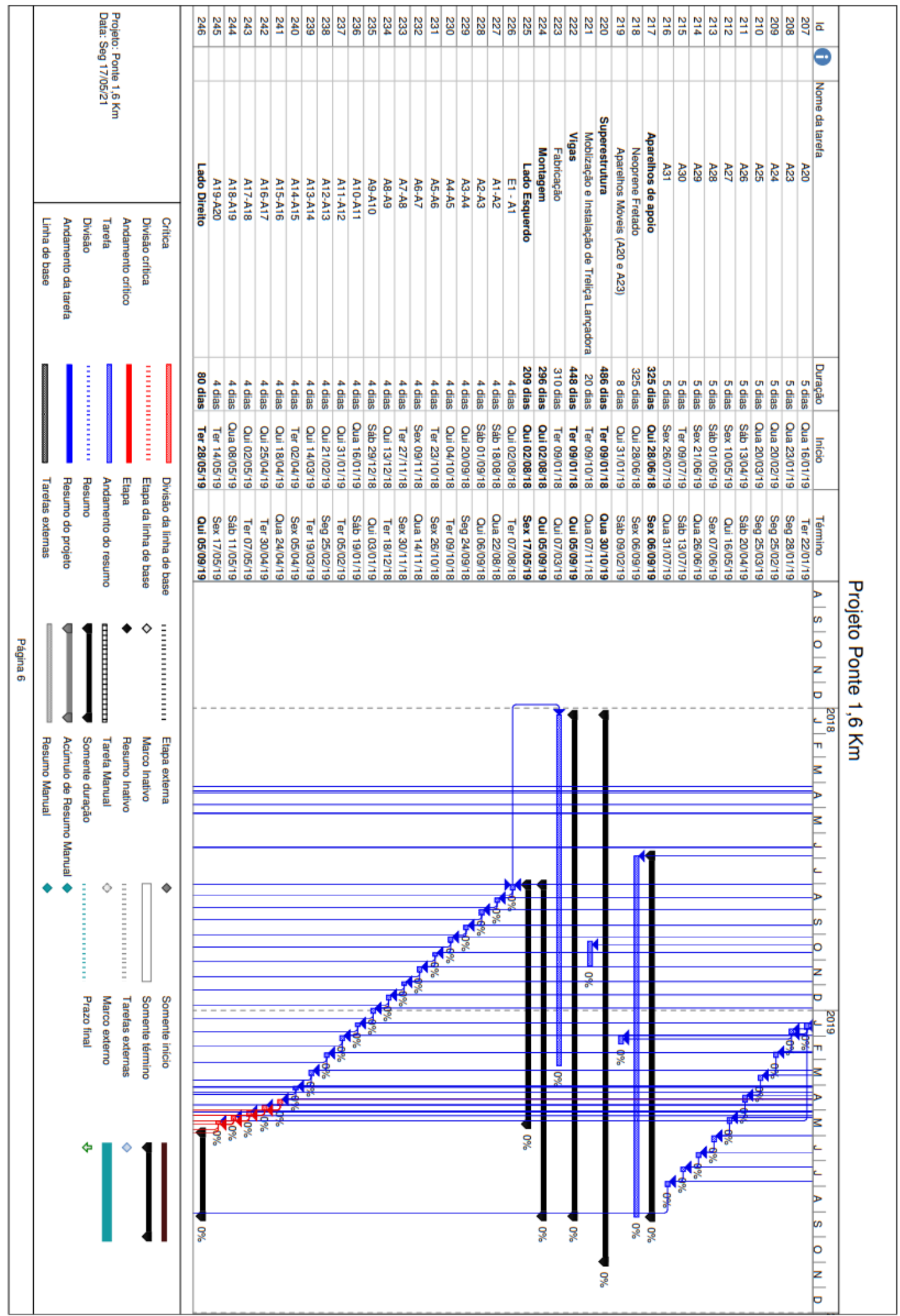

Figura 26 - Cronograma Ponte 1,6 Km 


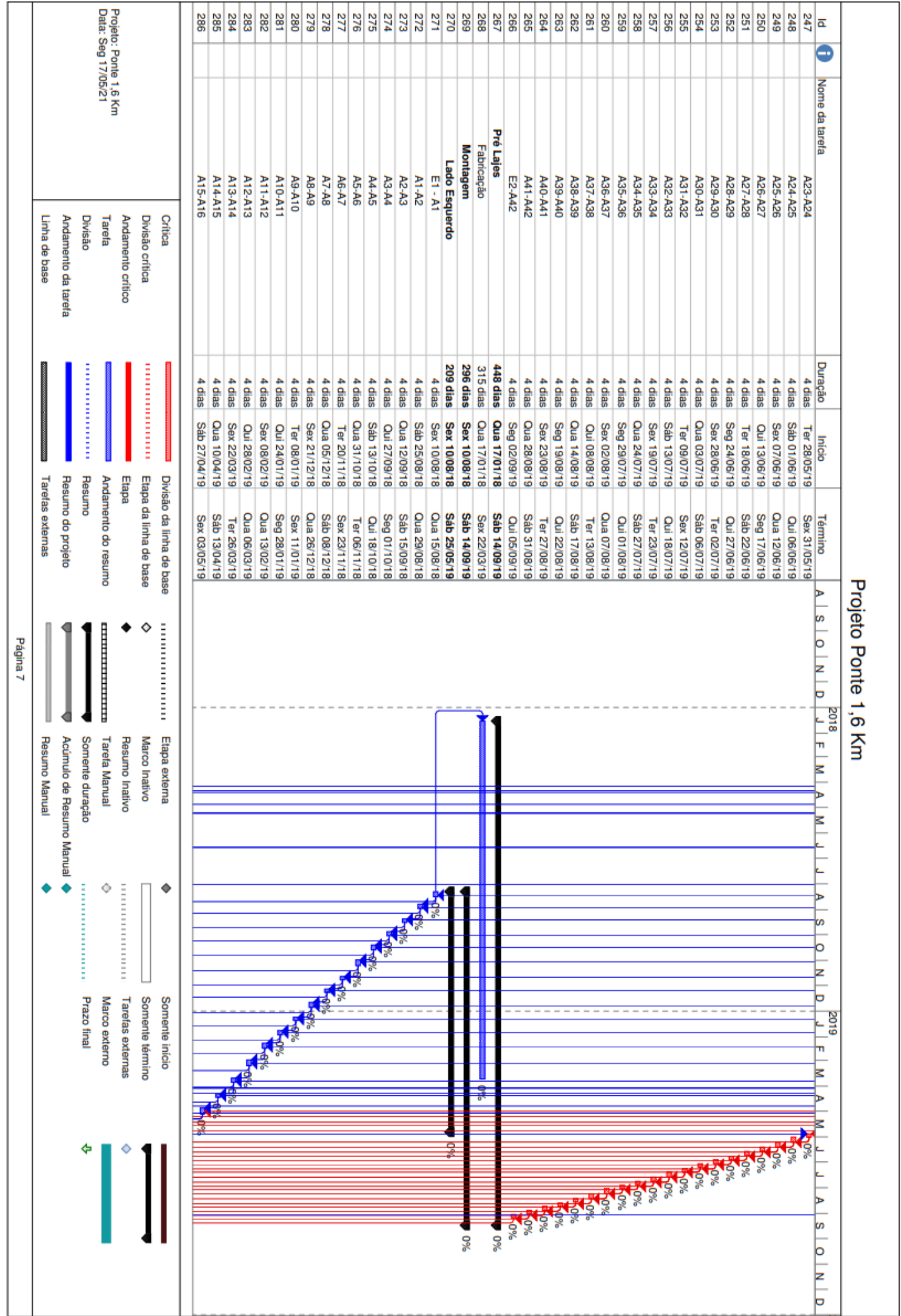

Figura 27 - Cronograma Ponte 1,6 Km 


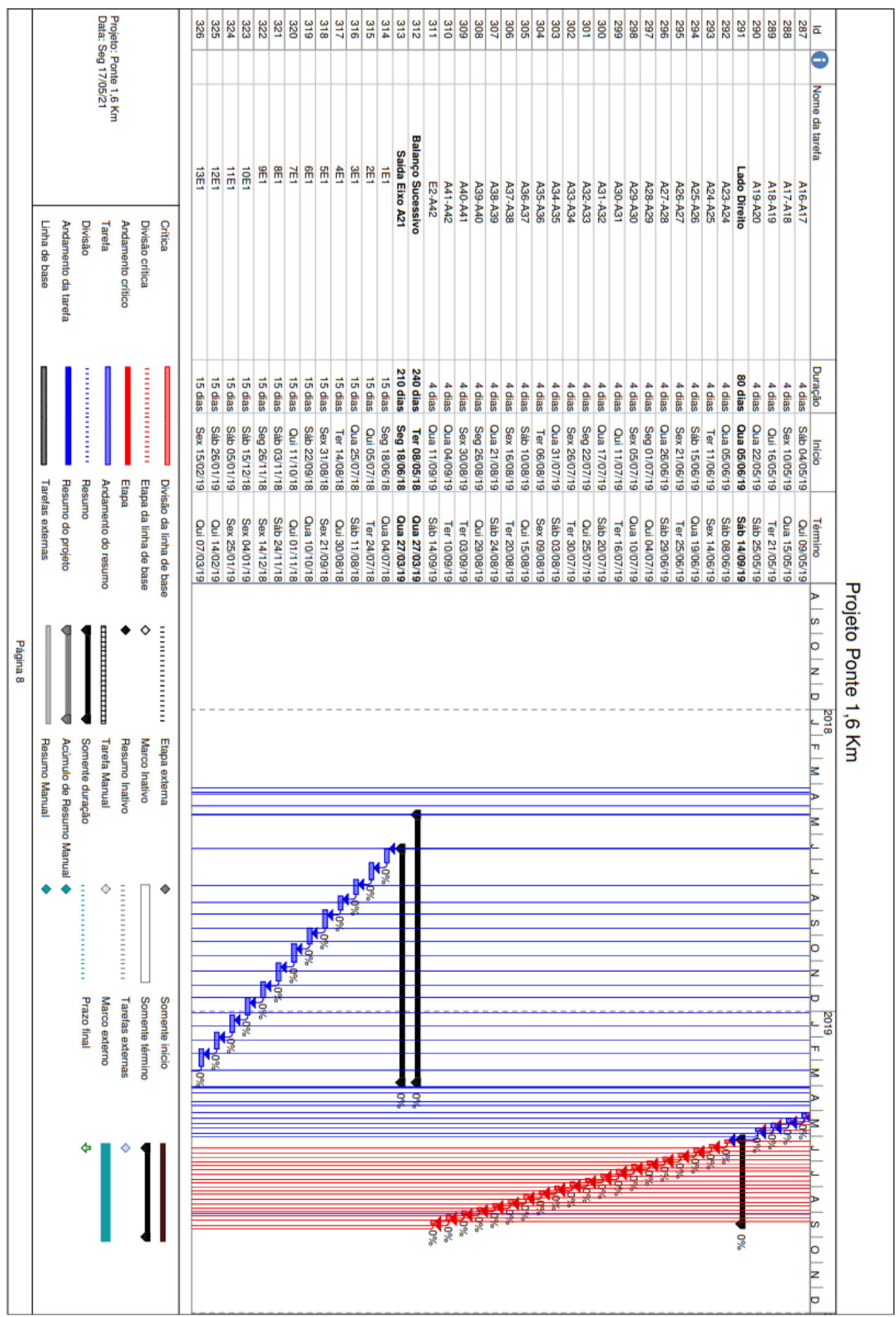

Figura 28 - Cronograma Ponte 1,6 Km 


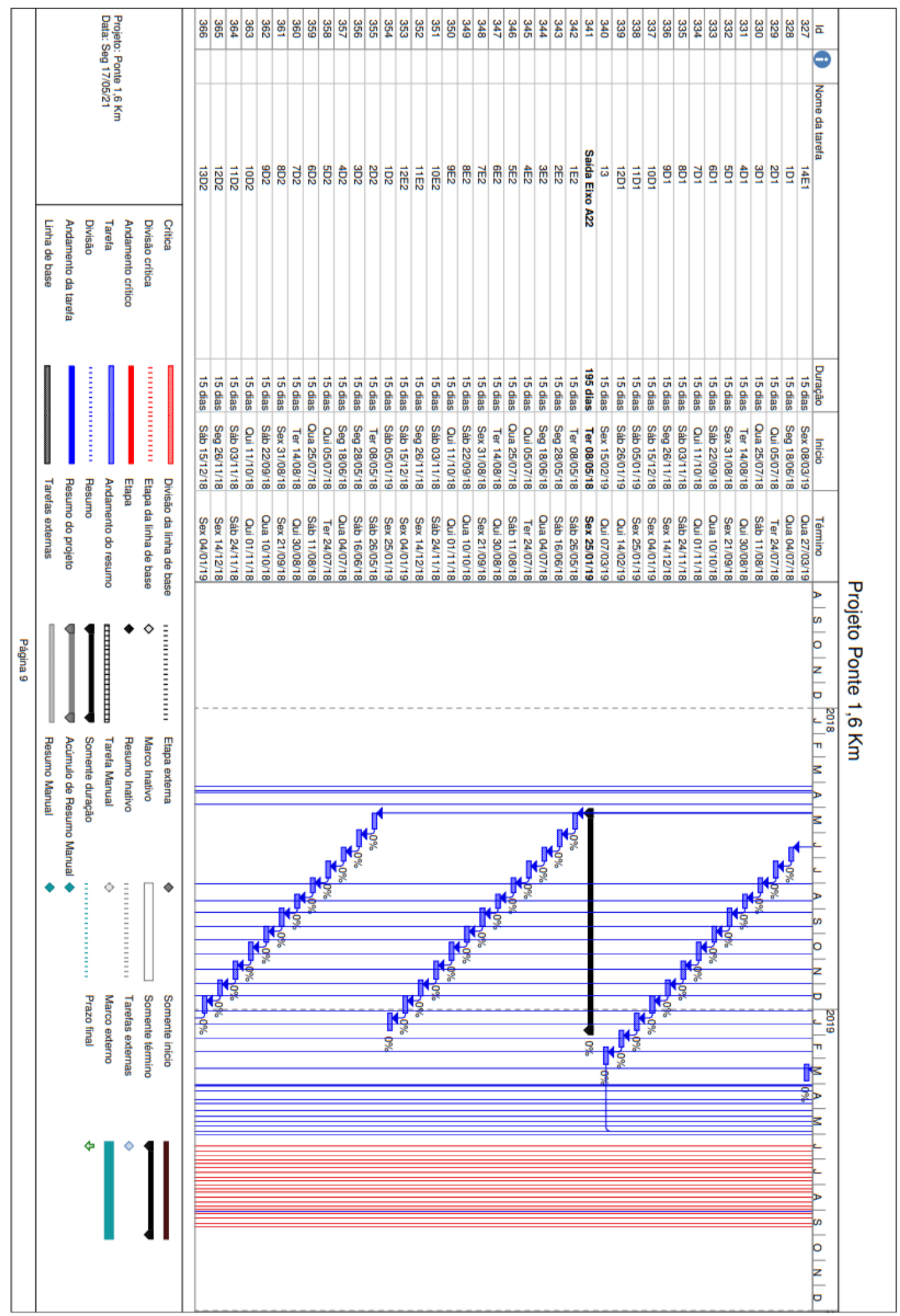

Figura 29 - Cronograma Ponte 1,6 Km 


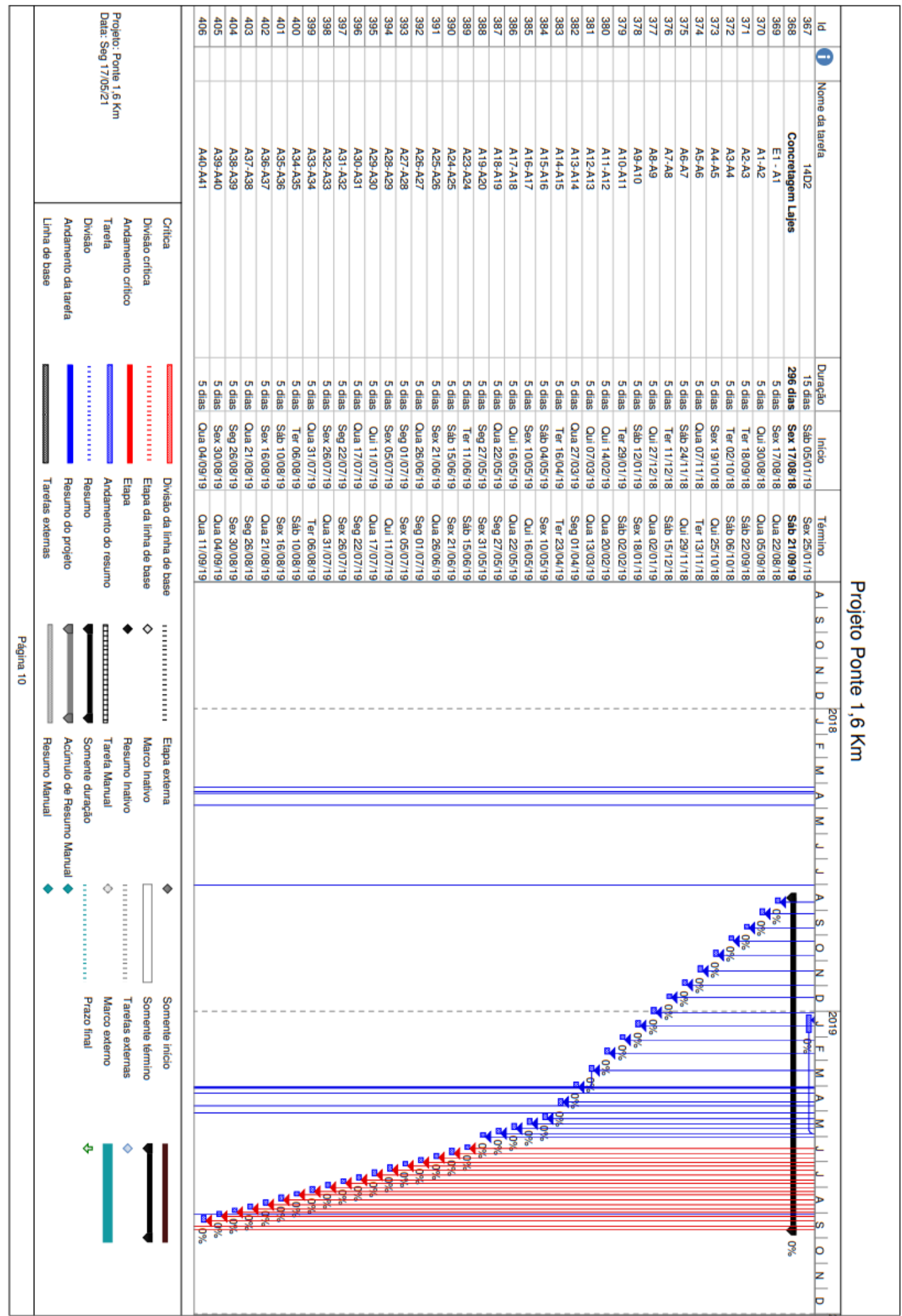

Figura 30 - Cronograma Ponte 1,6 Km 


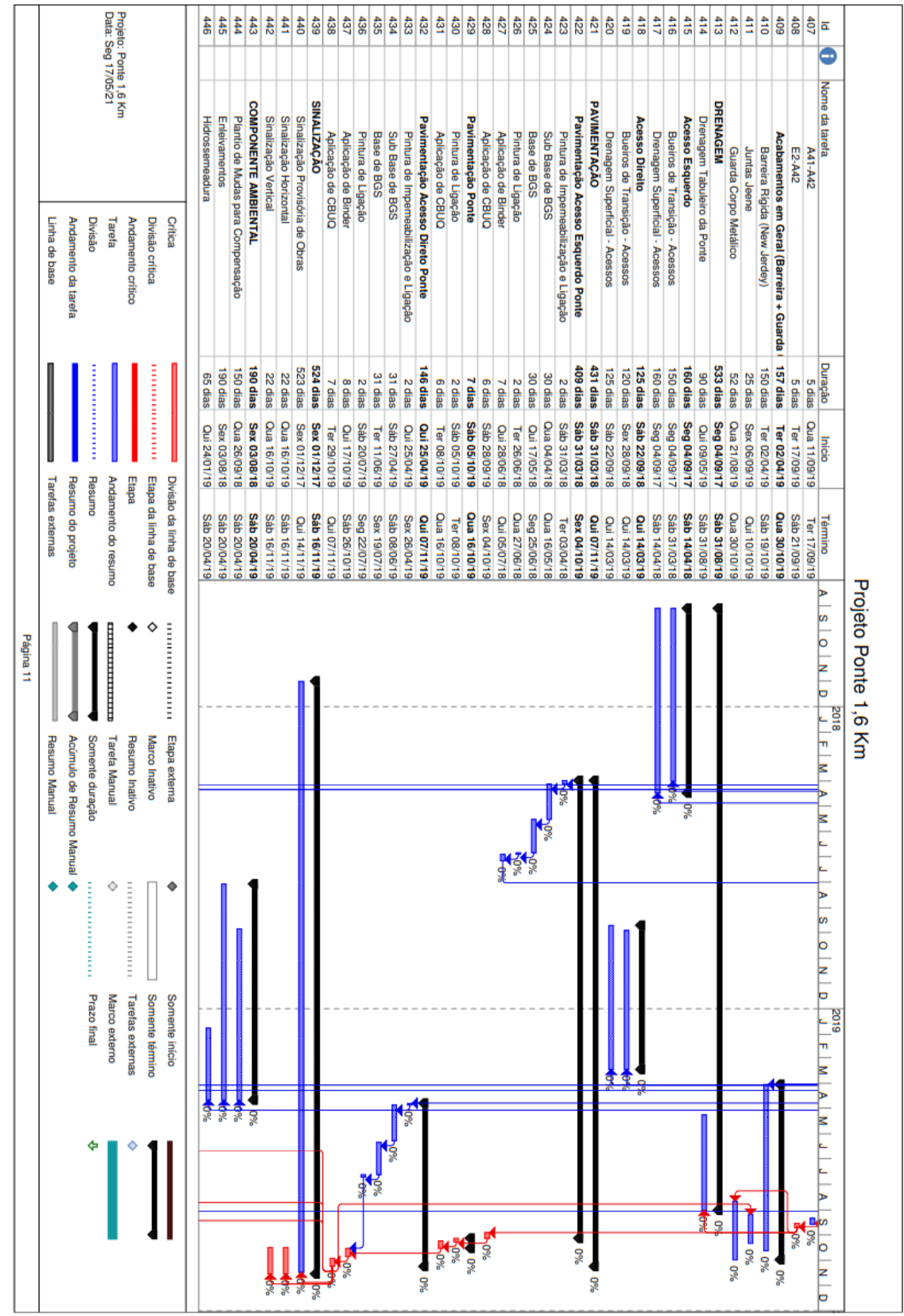

Figura 31 - Cronograma Ponte 1,6 Km 


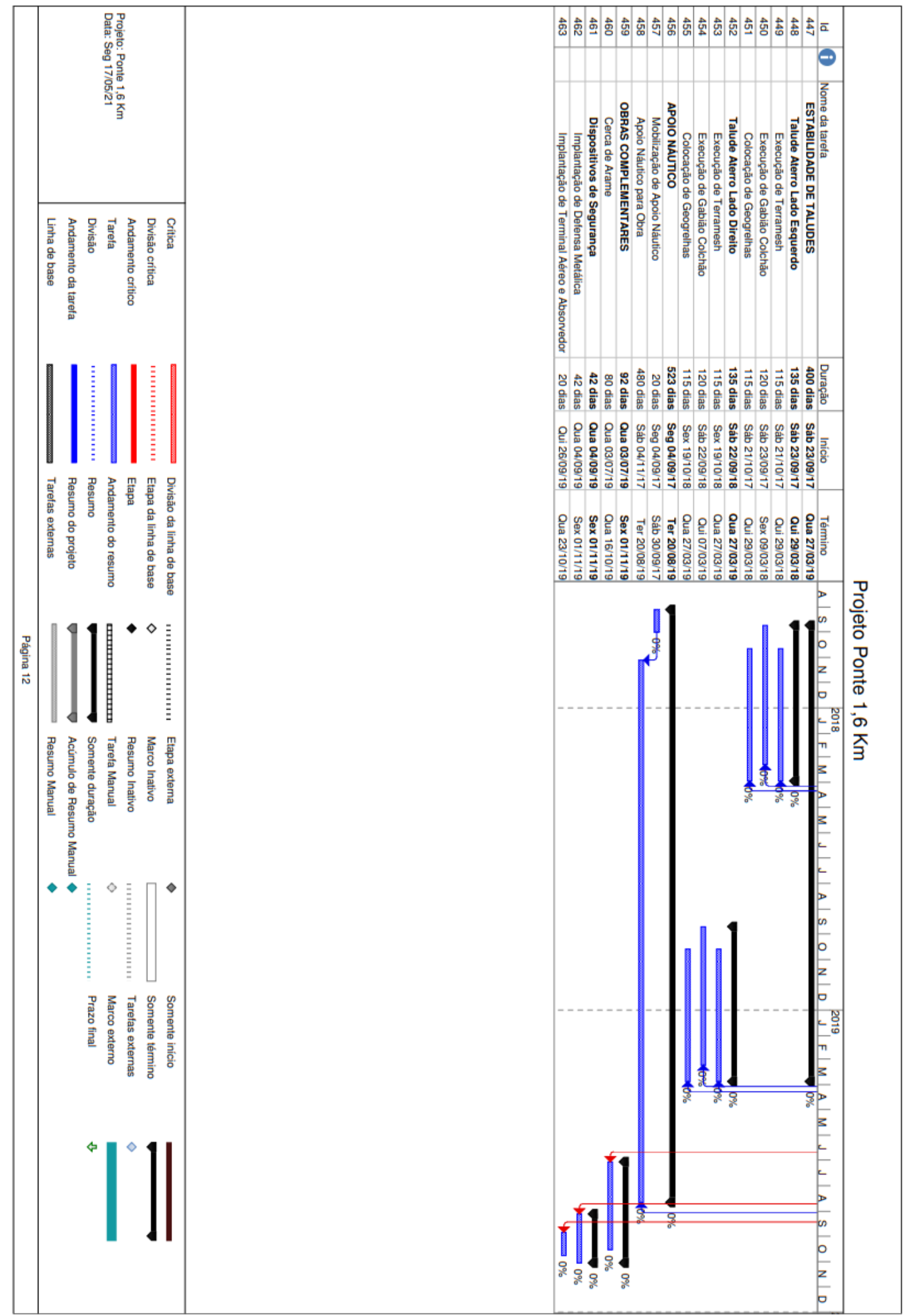

Figura 32 - Cronograma Ponte 1,6 Km 